MÁRIO SÉRGIO SOBRINHO

$\mathrm{N}^{\circ}$ USP 3172867

DEPARTAMENTO DE DIREITO PROCESSUAL

\title{
REGISTRO CRIMINAL. ANÁLISE E PROPOSTAS PARA SUA ESTRUTURAÇÃO NO PROCESSO PENAL SOB O ENFOQUE DA EFICIÊNCIA E DO GARANTISMO
}

TESE DE DOUTORADO

ORIENTADOR

PROFESSOR TITULAR: ANTONIO SCARANCE FERNANDES

UNIVERSIDADE DE SÃO PAULO

FACULDADE DE DIREITO DO LARGO DE SÃO FRANCISCO

SÃO PAULO - 2009 


\section{Sumário}

1. PRESSUPOSTOS CONSTITUCIONAIS E FUNDAMENTOS ......................... 10

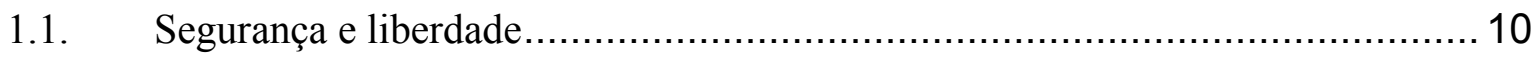

1.2. Aplicação do princípio da proporcionalidade ...................................... 15

1.3. Equilíbrio entre eficiência e garantismo......................................... 20

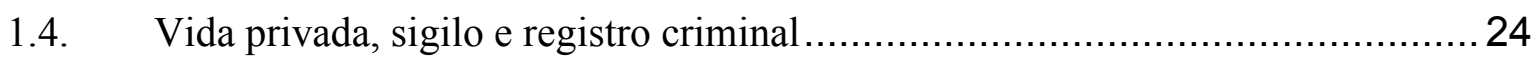

1.5. Contraditório, presunção de inocência e registro criminal ............................. 30

1.6. Conceito e finalidade do registro criminal....................................... 34

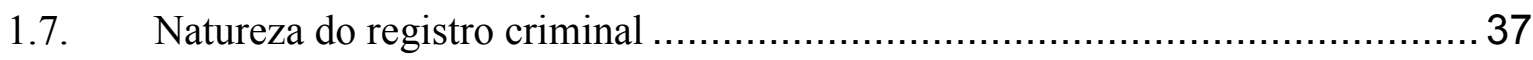

1.8. Conteúdo, centralização e principais características do registro criminal ...........41

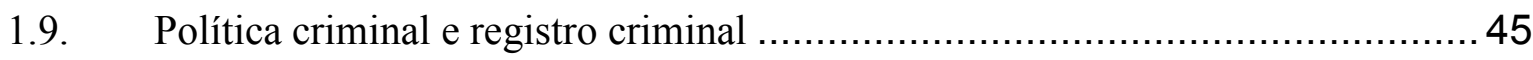

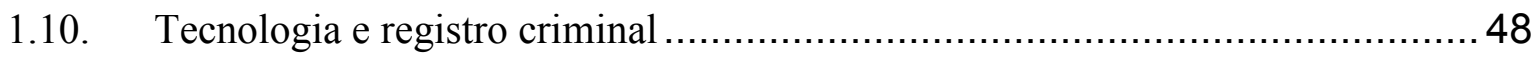

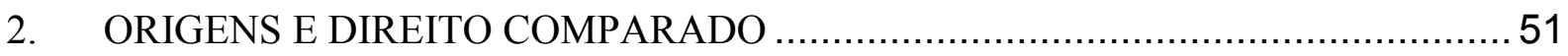

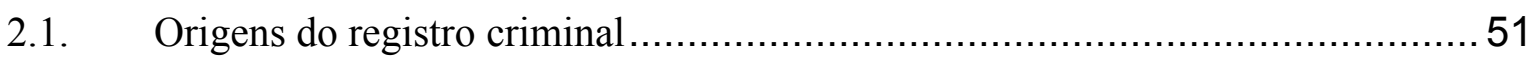

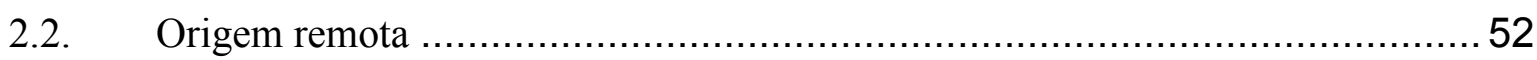

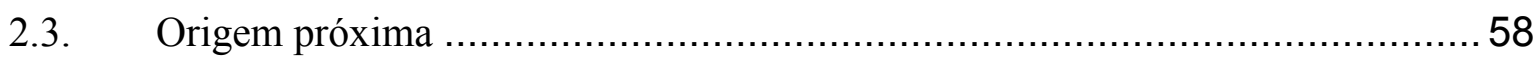

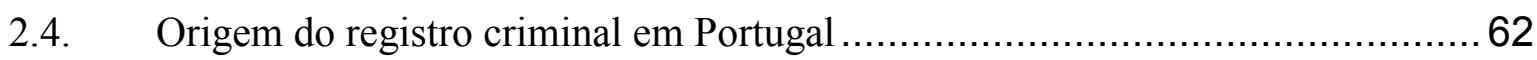

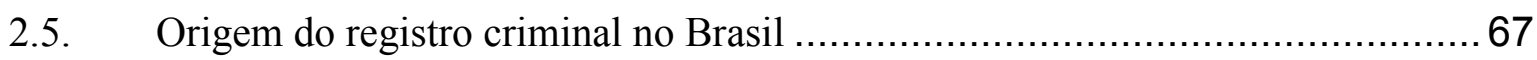

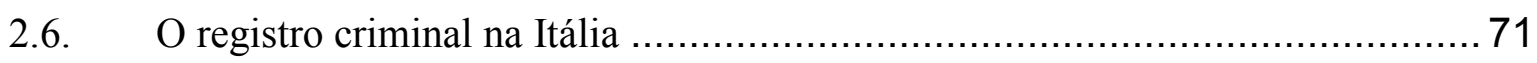

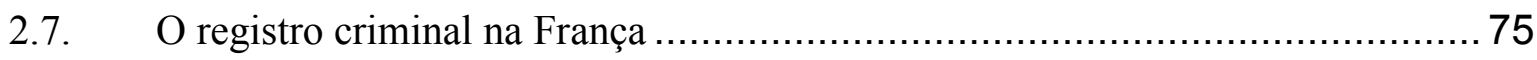

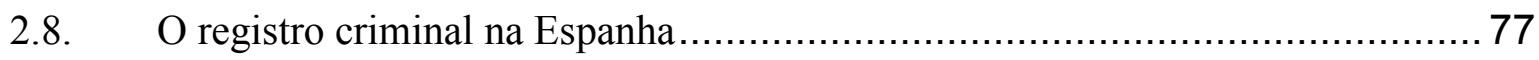

2.9. Referências gerais ao registro criminal em outros países ......................... 80

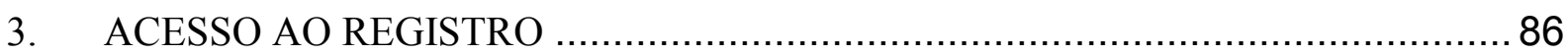

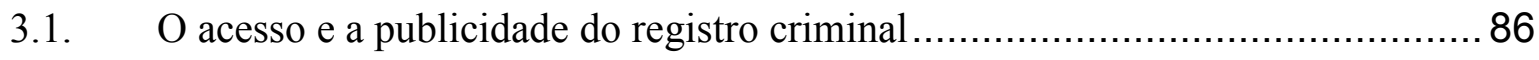

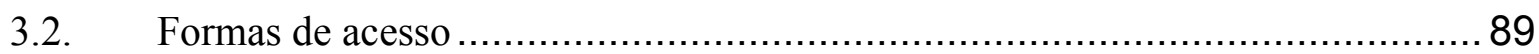

3.3. Acesso para fins investigativos e processuais ..................................... 94 


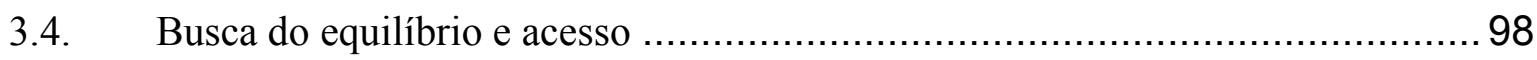

3.5. Acesso para fins particulares e administrativos.............................................. 104

3.6. Continuação ao acesso para fins particulares e administrativos ...................... 108

3.7. Restrição de acesso para fins particulares e administrativos ........................... 112

3.8. Acesso especial e acesso para fins estatísticos e científicos............................ 116

3.9. Justa causa e acesso legal para fins diversos............................................. 118

4. FUNCIONAMENTO DO REGISTRO E TEMAS CORRELATOS........................126

4.1. O funcionamento do registro criminal brasileiro ......................................... 126

4.2. Características gerais do registro policial ................................................... 130

4.3. Notas sobre a evolução do registro policial português ....................................... 135

4.4. Cadastros criminais mantidos pelo Ministério Público ………....................... 138

4.5. Infração penal de menor potencial ofensivo e registro criminal ......................... 141

4.6. Suspensão processual e registro criminal .............................................. 147

4.7. Rol de culpados, folha de antecedentes e registro criminal............................. 151

4.8. Reincidência e registro criminal ................................................................ 155

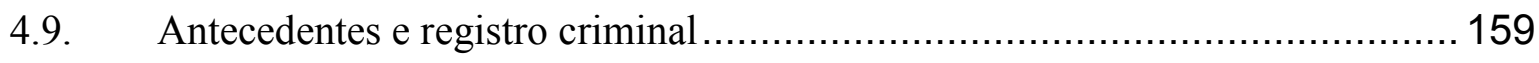

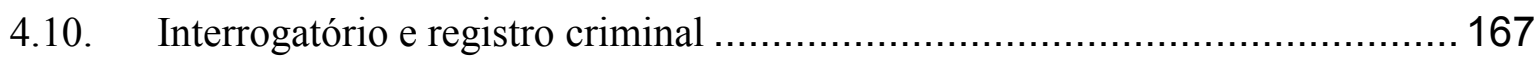

4.11. Execução penal e registro criminal......................................................... 173

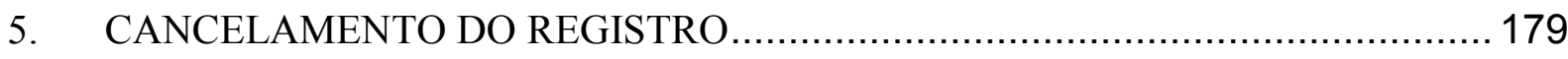

5.1. Cancelamento, eliminação e valor histórico do registro criminal ...................... 179

5.2. Temporariedade do registro criminal................................................. 186

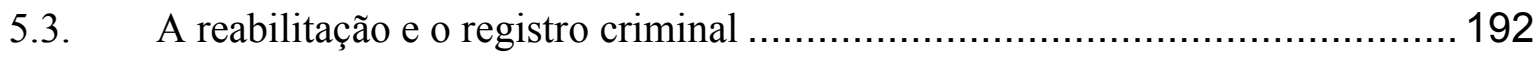

5.4. Outros aspectos da reabilitação e do registro criminal ................................... 195

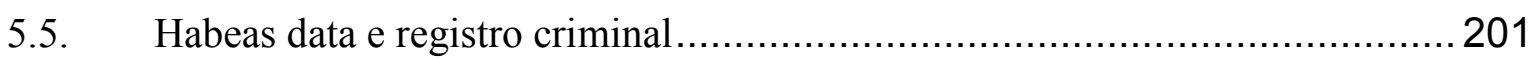

5.6. Mandado de segurança, habeas corpus e registro criminal ............................. 208

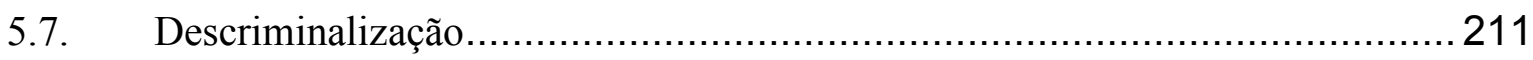

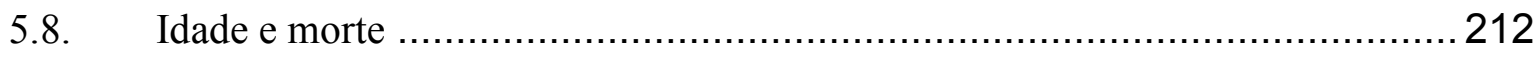


5.9. Pena suspensa, anistia e prescrição ................................................... 214

5.10. Cancelamento do registro criminal e exclusão da prova ............................ 218

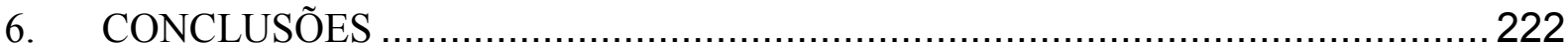

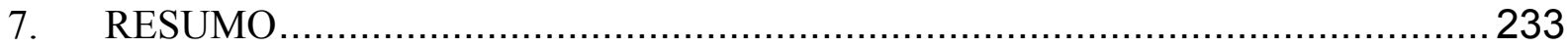

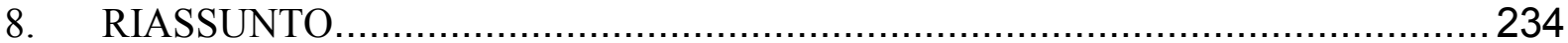

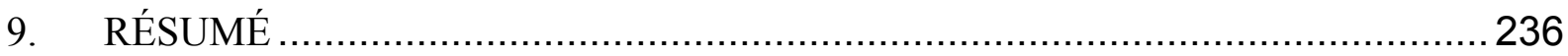

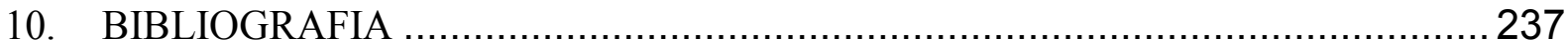




\section{INTRODUÇÃO}

Temas que interessam ao Direito Processual Penal, como a identificação e o registro criminal, ainda são pouco estudados no Brasil, especialmente ao se verificar que determinadas falhas ou interpretações indevidas das informações neles inseridas e armazenadas podem refletir na privacidade e liberdade da pessoa, valores esses protegidos pela Constituição Federal.

Depois do estudo da identificação criminal, "procedimento técnico-científico por meio do qual se identifica alguém, reencontrando-lhe a identidade, ou a descobrindo, por necessidade jurídica" ${ }^{, 1}$ foi notada a necessidade de também conhecer o registro criminal. ${ }^{2}$

São múltiplas as finalidades assumidas pelo registro criminal no Brasil, mas neste estudo o instituto será enfocado, essencialmente, sob a ótica processual penal pela análise do seu papel de compilar as anotações referentes aos antecedentes penais dos autores de crimes para demonstrar reincidência, apontar antecedentes criminais, fornecer informações a respeito da pessoa convocada a exercer as funções de jurado ou perito não-oficial, enfim, auxiliar a justiça criminal, sem esquecer da contribuição prestada à investigação acerca da autoria de determinados crimes. Existem outros fins para os quais o registro é empregado, entre eles, indicar a idoneidade penal de candidatos ao serviço público ou daqueles que pretendem exercer determinado tipo de trabalho privado e apontar a existência de condenação por falso testemunho gerador de suspeição da testemunha no processo civil, os quais também serão analisados.

É preciso regular o uso do registro criminal porque, paralelamente ao seu emprego legítimo por meio do exame da folha de antecedentes criminais e das certidões, é possível ocorrer a utilização imprópria das informações nele compiladas. Isso acontece, por exemplo, pela divulgação da informação do arquivamento de um inquérito policial para além daqueles que deveriam conhecê-la oficialmente ou pelo emprego desse dado para classificar, indevidamente, pessoa acusada por novo crime como portador de maus antecedentes criminais.

Soluções modernas, especificamente nos campos da tecnologia e informática, ao mesmo tempo que agilizam buscar informações reunidas nos bancos de dados que

\footnotetext{
${ }^{1}$ PITOMBO, Sérgio Marcos de Moraes. A identificação processual penal e a Constituição de 1988. $R T$, São Paulo, n. 635, p. 172, set. 1988.

${ }^{2}$ SOBRINHO, Mário Sérgio. A identificação criminal. São Paulo: RT, 2003. 197 p.
} 
compõem o registro criminal, poderão ampliar o risco dos acessos irregulares, sendo recomendado analisar se os cuidados existentes para protegê-los são eficazes.

Consultas aos mencionados bancos de dados, normalmente realizadas por funcionários dos órgãos estatais encarregados de investigar, processar e julgar crimes, facilitam o resgate das informações criminais antigas, às vezes expondo o indivíduo que cometeu certo crime logo depois de atingir a maioridade penal à divulgação dessa informação até o final da sua vida.

É preciso discutir a permanência temporal das informações no registro criminal. Fixar prazo para manter a anotação desabonadora acessível faria o registro criminal também se curvar ao tempo e acompanhar as soluções que o Direito Penal e Processual Penal brasileiros adotaram, por exemplo, ao limitar em 30 anos o período máximo para o cumprimento da pena privativa de liberdade e ao fixar em 20 o limite superior da prescrição.

Manter inalterado o conteúdo e inexistir prazo para excluir anotações são causas que fundamentam com freqüência pedidos para correção e cancelamento do registro criminal dirigidos aos juízes e tribunais, especialmente depois do arquivamento da investigação policial, requerimento feito também nos casos de absolvição por sentença judicial. Esses pleitos, não abrangidos pela reabilitação criminal, geralmente se fundam no receio da divulgação e emprego irregular da informação mantida no registro criminal.

O sigilo das anotações do registro, também deveria ser mais bem trabalhado pela legislação brasileira, inclusive para alinhar-se à proteção constitucional da privacidade, pois na área criminal somente é considerada expressamente secreta ou sigilosa a inscrição “com a nota de suspensão" do sursis não revogado ${ }^{3}$ e o registro do processo e da condenação, a partir da concessão da reabilitação criminal. ${ }^{4}$

No campo da publicidade do registro, embora não se refira ao sigilo e também não se relacione a decisões judiciais condenatórias, a Lei ${ }^{0}$ 9.099, de 1995, ${ }^{5}$ merece destaque. Referida lei se orientou na proteção da privacidade da pessoa ao impedir que a transação penal aplicada consensualmente ao autor de infração de menor potencial ofensivo caracterizasse reincidência e condicionou fosse registrada somente para obstar a repetição da transação antes de 5 (cinco) anos.

\footnotetext{
${ }^{3}$ Conforme artigo 709 do Código de Processo Penal e artigo 163 da Lei de Execução Penal. No item 3.3 deste estudo, foram feitas considerações acerca do mencionado artigo do Código de Processo Penal.

${ }^{4}$ Artigo 93, caput, do Código Penal e artigo 748 do Código de Processo Penal.

${ }^{5}$ Especialmente artigo 76 , parágrafos $4^{\circ}$ e $6^{\circ}$.
} 
Entretanto, ressalvadas as hipóteses do sigilo do sursis e da reabilitação, além da normatização peculiar referente à transação penal, a precária regulamentação legal relativa à inserção, ao acesso, à manutenção, ao cancelamento e à preservação do sigilo protetor das anotações do registro criminal facilita a produção de decisões judiciais divergentes em resposta aos pedidos para alteração das anotações do registro criminal.

Requerimentos feitos pelos interessados para excluir anotações relacionadas ao registro de inquéritos policiais arquivados por vezes são indeferidos por juízes e tribunais sob o argumento comum da necessidade de o juiz conhecer amplamente os antecedentes criminais e do caráter sigiloso dessa anotação. ${ }^{6}$

Outras decisões judiciais consideram em determinadas situações ser possível alterar o registro, pois anotações nele inseridas não devem servir como fonte para a expedição de certidões relativas a inquéritos policiais arquivados, enquanto o cancelamento de certas informações visa preservar a intimidade do indivíduo ${ }^{7}$ ou evitar-lhe prejuízos futuros, ${ }^{8}$ embora tais decisões careçam de explicitar o fundamento legal ou constitucional do sigilo do registro que objetiva resguardar a intimidade da pessoa.

No caso de o acusado requerer o cancelamento da informação anotada no registro criminal, depois de absolvido por decisão judicial com trânsito em julgado, os julgados somente acolhem essa modalidade de requerimento se a absolvição se fundou no fato de não ter o acusado concorrido para a infração penal $^{9}$ ou se reconhecer certos fundamentos para a absolvição, como a exclusão da ilicitude. ${ }^{10}$

${ }^{6}$ Foi decidido que é inadmissível excluir as anotações existentes no cadastro do Instituto de Identificação Ricardo Gumbleton Daunt (IIRGD), em São Paulo, porque são esses antecedentes imprescindíveis para o conhecimento da vida pregressa do indivíduo e de interesse judicial. O julgado, que assim entendeu, apontou que a manutenção do registro encontra base no artigo $6^{\circ}$, inciso VIII, do Código de Processo Penal, e que os dados nele contidos são sigilosos (BRASIL. Tribunal de Justiça. Mandado de Segurança n ${ }^{\circ}$ 416.545-3/6-00, Relator: Almeida Braga, da $2^{\mathrm{a}}$ Câmara Criminal, São Paulo, SP, 26 de maio de 2003. Jurisprudência do Tribunal de Justiça, São Paulo, v. 268, p. 592-598, set. 2003).

${ }^{7}$ Ementas dos acórdãos proferidos no Recurso Ordinário em Habeas Corpus $\mathrm{n}^{\circ}$ 14.376/SP, Relator Ministro José Arnaldo da Fonseca, da $5^{\mathrm{a}}$ Turma (BRASIL. Superior Tribunal de Justiça. Brasília, DF, 2 de março de 2004. Diário Oficial [da] República Federativa do Brasil, Brasília, DF, 29 mar. 2004. p. 254) e no Recurso Ordinário em Mandado de Segurança $n^{\circ}$ 16.202/SP, Relator Ministro Felix Fischer, da $5^{\mathrm{a}}$ Turma (BRASIL. Superior Tribunal de Justiça. Brasília, DF, 17 de junho de 2003. Diário Oficial [da] República Federativa do Brasil, Brasília, DF, 12 ago. 2003. p. 246).

${ }^{8}$ Ementa do acórdão prolatado no Recurso Ordinário em Mandado de Segurança n ${ }^{\circ}$ 9.879/SP, Relator Ministro Gilson Dipp, da 5a Turma (BRASIL. Superior Tribunal de Justiça. Brasília, DF, 9 de abril de 2002. Diário Oficial [da] República Federativa do Brasil, Brasília, DF, 3 jun. 2002. p. 214).

9 A ementa do julgado menciona ser "legítima a pretensão de paciente que, absolvido por não ter concorrido para a infração penal, requer sejam apagadas, de sua folha de antecedentes, quaisquer referências ao processo criminal, visando a evitar prejuízos futuros." Acórdão proferido no Habeas Corpus n ${ }^{\circ}$ 15.206/RJ, Ministro Gilson Dipp, da $5^{\mathrm{a}}$ Turma (BRASIL. Superior Tribunal de Justiça. Brasília, DF, 29 de outubro de 2001. Diário Oficial [da] República Federativa do Brasil, Brasília, DF, 29 out. 2001. p. 224).

10 BRASIL. Tribunal de Justiça. Mandado de Segurança n ${ }^{\mathbf{o}}$ 397.319-3/9, Relator: Damião Cogan, da $5^{\text {a }}$ 
Apesar dos apontados entendimentos judiciais divergentes, é possível visualizar inclinação da jurisprudência nacional, especialmente produzida pelo Superior Tribunal de Justiça, em assegurar a inviolabilidade da privacidade da pessoa humana ante o risco da divulgação indevida das informações reunidas no registro criminal. Referida tendência será analisada e debatida sob a ótica da garantia da privacidade e do sigilo da comunicação dos dados pessoais.

O estudo pretende demonstrar que a informação inserida no registro criminal se equipara a um dado sensível e, por isso, exige manuseio criterioso, restrito e regido por lei.

Os aspectos básicos da legislação a qual se supõe deva ser editada para cuidar do registro criminal e os cuidados que juízes e demais profissionais da área jurídica deveriam dispensar ao assunto, independentemente de qualquer mudança legislativa, são referidos ao longo texto. Entretanto, os principais pontos de sustentação dessas idéias serão alinhavados nas conclusões, apresentadas com o objetivo de permitir ao registro criminal estruturar-se sob os valores da eficiência e do garantismo, proporcionando acesso rápido e seguro aos dados nele compilados, sem exposição indevida da privacidade da pessoa pela violação do sigilo dos dados criminais.

O desenvolvimento deste trabalho demandará análise das características do registro criminal brasileiro e comparação, sob determinados ângulos, ao perfil assumido pelo instituto em outros países, especialmente em Portugal e Espanha, em razão do incremento dado ao assunto nesses países, bem como exigirá estudo objetivo do registro policial, destacando-se a autonomia que o registro criminal deve ostentar em relação a ele. Com essa abordagem, espera-se apontar idéias que orientem a inserção, acesso, manutenção, cancelamento e sigilo dos dados do registro criminal, permitindo emprego regular e eficiente dos dados, com redução dos riscos à privacidade e liberdade das pessoas.

Os incisos X e XII do artigo $5^{\circ}$ da Constituição Federal brasileira oferecerão base garantista e asseguradora da privacidade e do sigilo dos dados das pessoas cujos nomes estão inscritos no registro criminal. A partir dessa base, será possível entender que o País deveria empreender esforços para estruturar um sistema de registro criminal eficiente, autônomo e apto a fornecer elementos para comprovar condenações anteriores e antecedentes criminais das pessoas em todo o território nacional.

Este estudo não abordará o acesso ao cadastro de processos mantido por 
determinados órgãos jurisdicionais a partir de consultas feitas pelo nome do acusado. Apesar de certos Tribunais facilitarem aos interessados acessar o acervo de dados processuais por meio da informática e da Internet, ${ }^{11}$ permitindo saber se determinada pessoa foi acusada de ser autora de crime, essa forma de acesso, que cumpre finalidade específica, exigiria abordagem própria e não integra o registro criminal, razões que desaconselham estudá-la conjuntamente.

O estudo do registro criminal, sob a ótica da eficiência e do garantismo, projetará eventuais alterações legislativas, mas durante o seu desenvolvimento e no final não serão apresentadas propostas específicas nesse sentido, por considerar-se que a análise das questões, o debate das idéias e as provocações feitas à comunidade jurídica e às autoridades públicas em geral sejam suficientes para propiciar outro olhar sobre o registro criminal.

É objetivo desta tese apresentar propostas que possam contribuir para o desenvolvimento do registro criminal brasileiro, ao expor o seu funcionamento e a necessidade do seu emprego e estruturação sob valores constitucionais, trazendo idéias que poderão sustentar alterações legislativas e mudanças de paradigmas, entre elas, o cabimento de cancelar-se, em determinadas situações, anotações inseridas no registro criminal.

11 Francisco Bissoli Filho (Estigmas da criminalização: dos antecedentes à reincidência criminal. Obra Jurídica: Florianópolis, 1998. p. 24) ressalta que a influência crescente dos antecedentes na legislação criminal funciona como meio para desencadear o apartheid social, pois "os indivíduos detentores de antecedentes ou reincidentes criminais passam a pertencer a um grupo especial de pessoas, diferentes dos demais cidadãos, diferenciados pelo seu estigma, de modo que o sistema penal, a cada dia que passa, se torna mais feroz com este grupo de pessoas, a ponto de organizar banco de registro de dados acerca de indivíduos envolvidos nos processos de criminalização, inclusive via internet" (itálico original). 


\section{PRESSUPOSTOS CONSTITUCIONAIS E FUNDAMENTOS}

\subsection{Segurança e liberdade}

O processo criminal, instaurado para a apuração da ocorrência dos crimes e a imposição das penas, relaciona-se com o direito à liberdade e à segurança. Esses direitos fundamentais previstos no artigo $5^{\circ}$, caput, da Constituição Federal, impõem ao Estado, ao realizar a persecução penal, criar órgãos e adotar procedimentos que resguardem a segurança das pessoas e, ao mesmo tempo, garantam o gozo da liberdade. ${ }^{12}$

Durante a tramitação do processo criminal, o juiz conhece os antecedentes criminais reunidos no registro e examina as informações da folha de antecedentes e certidões, necessitando abordá-los em determinadas ocasiões da marcha processual, especialmente, ao condenar e impor pena ao acusado.

É possível manusear as informações reunidas no registro criminal se houver previsão legal, autorização do interessado, determinação judicial ou justa causa. Fora disso deve ser vedado que terceiros tenham acesso às referidas informações.

Ocorre ofensa à privacidade da pessoa pela divulgação dos dados inseridos em sua folha de antecedentes criminais além das situações acima indicadas. A existência de justa causa para a investigação ou para o ajuizamento de ação penal, nos casos em que a primeira não permitir a acusação ou o segundo não resultar na fixação de pena ou medida de segurança, não amparará divulgar essa investigação ou processo exceto dentro daquelas situações expostas.

Em determinadas hipóteses, embora o acesso à informação seja regular, a autoridade responsável pela interpretação dos dados poderá fazer juízo equivocado a respeito da reincidência ou maus antecedentes e, em razão disso, produzir reflexos processuais indevidos.

A existência de prova da prática de crime doloso punido com pena de reclusão e a presença de indício suficiente de autoria delitiva são os pressupostos exigíveis para decretação da prisão preventiva, modalidade essa de prisão provisória que pode ser decretada pelo juiz a qualquer tempo, inclusive antes do ajuizamento da ação penal. Além

\footnotetext{
${ }^{12}$ FERNANDES, Antonio Scarance. Procedimento no processo penal: noções, perspectivas simplificadoras e rumos no direito brasileiro. São Paulo: RT, 2005. p. 34.
} 
da existência dos pressupostos, exigem-se presentes requisitos para decretar a prisão preventiva, entre eles, a garantia da ordem pública e segurança da aplicação da lei penal. ${ }^{13}$

Os mencionados requisitos, também chamados motivos ou fundamentos para a prisão preventiva, são visualizados com maior facilidade se a pessoa que se pretende prender preventivamente sofreu outra condenação. A condenação anterior por sentença com trânsito em julgado ${ }^{14}$ é argumento legal que serve para fundamentar essa modalidade de prisão processual, exceto se entre a data do cumprimento ou extinção da pena imposta na condenação anterior tiver decorrido período de tempo superior ao "prazo depurador" de 5 (cinco) anos. ${ }^{15}$

Entretanto, a comprovação de antecedentes criminais desabonadores, desacompanhados dos pressupostos e quaisquer requisitos previstos no artigo 312 do Código de Processo Penal, não justificam a decretação de prisão preventiva. Embora possível ao juiz, e dele esperado, analisar previamente o registro criminal daquele que pode ser alcançado por ordem de prisão preventiva, a mera existência de antecedentes criminais não poderá servir para justificá-la se ausentes os pressupostos relativos à autoria e materialidade do crime em relação ao qual se pretende decretar a custódia e inexistir demonstração de algum requisito, entre aqueles exigidos para sua decretação, como a garantia da ordem pública ou econômica, a conveniência da instrução criminal e a segurança da aplicação da lei penal. ${ }^{16}$

Esse modo de encarar os antecedentes desabonadores sem deles extrair força para subsidiar decreto de prisão preventiva foi robustecido por recentes mudanças do Código de Processo Penal, ou seja, a alteração do artigo 408, $\S 2^{\circ}$, do Código de Processo Penal, que

\footnotetext{
${ }^{13}$ Artigos 312 do Código de Processo Penal.

${ }^{14}$ A interpretação rigorosa desse dispositivo legal é observada no trecho a seguir transcrito, que é encontrado na lição de José Frederico Marques (Elementos de direito processual penal. Campinas: Bookseller, 1997. v. IV, p. 60): "Não importa, no caso, que, no crime doloso pelo qual o réu foi anteriormente condenado, só se lhe tenha imposto pena de multa: o que se leva em consideração, ao cuidar-se de verificar a existência de reincidente específico, o preceptum juris da norma incriminadora e não o preceito sancionador. A relevância deste último é no momento de se aplicar a pena por novo crime."

${ }^{15}$ Artigo 313 do Código de Processo Penal. Cf., também, DELMANTO JÚNIOR, Roberto. As modalidades de prisão provisória e seu prazo de duração. Rio de Janeiro: Renovar, 1998. p. 142. Nesse texto, o autor faz referência ao "prazo depurador" da reincidência.

${ }^{16}$ Francisco Bueno Arús (La cancelación de antecedentes penales. Barcelona: Thomson Civitas, 2006. p. 53-54) ao analisar os artigos 503 e 504 da Ley de Enjuiciamiento Criminal, modificados em 1986 e 2003 , firmou que o juiz, "para decretar la prisión provisional, habrá de tener en cuenta, entre otros extremos, 'la existencia de antecedentes penales no cancelados ni susceptibles de cancelación, derivados de condena por delito doloso' (art. 503, 1.1 ${ }^{\circ}$ )". O autor também critica a reforma legislativa que revogou a disposição que permitia que "la carencia de antecedentes penales o que éstos deban considerarse como cancelados" fossem aferidos em benefício do acusado, apontando que "las reformas de año 2003, y en aspecto que nos ocupa, en la línea del Derecho penal del enemigo, los antecedentes penales pueden ser valorados para perjudicar la situación de partida del reo, pero no para mejorarla, como antes."
} 
permitia ao juiz fosse o réu primário e de bons antecedentes deixar de decretar-lhe a prisão ou revogá-la, no caso de encontrar-se o acusado preso e também pela revogação do artigo 594, que impedia o acusado de apelar sem recolher-se à prisão, ou prestar fiança, salvo se primário e de bons antecedentes, assim reconhecido na sentença condenatória, ou condenado por crime de que se livre solto.

A primeira alteração referida está relacionada ao texto do revogado artigo $408, \S 2^{\circ}$, do Código de Processo Penal e foi introduzida pelo artigo 413, $\S 3^{\circ}$, incluído pela Lei $\mathrm{n}^{\circ}$ 11.689, de 9 de junho de 2008, com a seguinte redação: “o juiz decidirá, motivadamente, no caso de manutenção, revogação ou substituição da prisão ou medida restritiva de liberdade anteriormente decretada e, tratando-se de acusado solto, sobre a necessidade da decretação da prisão ou imposição de quaisquer das medidas previstas no Título IX do Livro I deste Código".

A segunda, é resultado da revogação do artigo 594 do Código de Processo Penal pela Lei $\mathrm{n}^{\mathrm{o}} 11.719$, de 20 de junho de 2008, que também inseriu parágrafo único ao artigo 387, no qual foi previsto que “o juiz decidirá, motivadamente, sobre a manutenção ou, se for o caso, imposição de prisão preventiva ou de outra medida cautelar, sem prejuízo do conhecimento da apelação que vier a ser interposta."

Cabe abordar outro assunto também relacionado ao registro criminal e à esfera da liberdade da pessoa, vista de modo amplo, pois aquele que foi condenado anteriormente à prática de crime com imposição de pena privativa de liberdade por sentença definitiva ou detenha antecedentes criminais desabonadores não receberá, caso apontado como autor de infração penal de menor potencial ofensivo, proposta de transação penal formulada pelo Ministério Público. Se o acusado estiver respondendo processo-crime, tiver sido condenado por outro crime, for reincidente ou detentor de antecedentes também lhe será vedada a proposta de suspensão condicional do processo.

Nessas situações, estará impedido de usufruir as medidas despenalizadoras reguladas pela Lei $n^{\circ} 9.099$, de 1995, cabendo ao órgão acusador, no primeiro caso, ajuizar a respectiva ação penal em face do autor do fato e, no segundo, zelar pelo seguimento daquela proposta em relação ao acusado. ${ }^{17}$

A existência de condenação anterior apurada para avaliar o cabimento da prisão preventiva e reincidência, maus antecedentes ou se está respondendo processo para o fim de impedir a aplicação das medidas despenalizadoras são situações comprovadas a partir dos

\footnotetext{
${ }^{17}$ Artigo 76, parágrafo $2^{\circ}$, incisos I e II e artigo 89, caput.
} 
dados fornecidos pelo registro criminal. Incidir na primeira delas, portanto, permitirá ao juiz restringir a liberdade do indiciado ou acusado e, na segunda, não afastará o suposto infrator de suportar os efeitos do ajuizamento da ação penal e a possibilidade da decretação de medidas restritivas da liberdade, seja no curso da tramitação da ação penal ou no momento da condenação.

Essas situações e constatações motivam o debate a respeito da inserção, manutenção e acesso dos dados inseridos no registro criminal diante da hipótese de as informações reunidas nesses sistemas exercerem influência ao menos, indireta, na esfera da liberdade da pessoa.

As referências pontuais feitas sobre a prisão preventiva e as medidas despenalizadoras tratadas pela Lei $n^{0}$ 9.099, de 1995, pretendem mostrar que a decretação dessa forma de restrição da liberdade individual e a vedação ao gozo das medidas referidas serão precedidas do exame dos antecedentes da pessoa permitido pela lei.

O confronto dos antecedentes criminais com a prisão preventiva e com as medidas despenalizadoras tratadas pela Lei $n^{\circ} 9.099$, de 1995, tem a finalidade de enfatizar o relevo dos dados fornecidos pelo registro criminal para fundamentar a decisão judicial que concede ou nega a prisão preventiva e a manifestação do órgão ministerial ao propor ou negar a transação e a suspensão processual.

O cancelamento de certos dados do registro criminal, tema oportunamente abordado, dificultaria a formulação de juízos equivocados a partir dessas informações e, conseqüentemente, poderia dificultar a imposição da prisão preventiva para aqueles condenados anteriormente, bem como que medidas despenalizadoras fossem negadas a partir de semelhantes juízos.

Além disso, é preciso proteger a privacidade da pessoa considerada autora de crime, mas não acusada em virtude do arquivamento do inquérito policial ou do reconhecimento de causa de extinção da punibilidade, bem como daquela que mesmo acusada em sede criminal, por qualquer razão, não sofreu imposição de pena ou medida de segurança.

Providências que reduzam o acesso aos dados cancelados do registro protegem não somente a privacidade, mas também, a liberdade da pessoa. Restringir o fornecimento das informações criminais dessa natureza evitará avaliações negativas sobre os antecedentes criminais de qualquer pessoa.

Cancelar essas informações ou impor sejam elas incapazes de servir para aferição dos antecedentes da pessoa são medidas protetivas para aquele que não foi condenado e 
cujos dados constam no registro criminal. É controvertido admitir que a reabilitação torna sigiloso o dado sobre o processo e a condenação, conforme dispõem os artigos 93 e seguintes do Código Penal e o artigo 748 do Código de Processo Penal, ${ }^{18}$ enquanto o dado referente à investigação que não gerou ação penal de natureza condenatória ou aquele relativo ao processo solucionado por decisão extintiva da punibilidade ou absolutória, com trânsito em julgado, permaneça anotado de modo perene e precariamente protegido pelo sigilo.

Sob outro ângulo, cabe citar que a esfera penal poderá assinalar efeitos que não atingem a liberdade da pessoa investigada ou acusada, mas daquela que divulgou, indevidamente, informação sigilosa por definição legal ou revelou fato que devia permanecer em segredo, permitindo restrição à liberdade de terceiro envolvido por essa divulgação indevida.

Essas condutas poderão configurar crime. O delito descrito no artigo 153, parágrafo $1^{\mathrm{o}}$-A, do Código Penal pune com pena de detenção de 1 (um) a 4 (quatro) anos e multa quem divulgar, sem justa causa, informação sigilosa ou reservada contida ou não nos sistemas de informações ou banco de dados da Administração Pública.

Caso o agente exerça função pública, o fato poderá configurar crime de violação do sigilo funcional pela revelação de fato conhecido por funcionário público que deva manter

\footnotetext{
${ }^{18}$ Existe controvérsia acerca da vigência do artigo 748 do Código de Processo Penal. Julio Fabbrini Mirabete (Execução penal: comentários à Lei n $\mathrm{n}^{\circ}$ 7.210, de 11-7-1984. 10. ed. São Paulo: Atlas, 2002. p. 440) entendia que esse dispositivo legal continuava em vigor, porque foram revogados pela Lei $\mathrm{n}^{\circ} 7.209$, de 1984 , que deu nova redação à Parte Geral do Código Penal, somente os artigos 743, 744 e 749, todos da lei processual penal. Para esse autor a normatização referente ao processamento da reabilitação prevista nos artigos 745 , 746, 747, 748 e 750, todos do Código de Processo Penal, também não alterada pela Lei de Execução Penal, continuava em vigor. Referências ao citado artigo de lei também são encontradas em texto jurídico (ARAS, Vladimir. Princípios do processo penal. Disponível em: <http://mundojuridico.adv.br/cgibin/upload/texto115(3).rtf>. Acesso em: 12 set. 2008) e julgado (BRASIL. Superior Tribunal de Justiça. Recurso Ordinário em Mandado de Segurança $n^{\circ}$ 6.761/SP, Relator: Ministro Luiz Vicente Cernicchiaro, da $6^{\text {a }}$ Turma, Brasília, DF, 10 de junho de 1996. Lex STJ, São Paulo, v. 92, p. 338-342, abr. 1997). Em sentido oposto, foi entendido que "em face da Lei 7.210/1984, que disciplinou por inteiro, a execução penal, não sobrevive o instituto da reabilitação, como previsto no art. 743 e segs. do CPP" (BRASIL. Tribunal Regional Federal - $1^{\text {a }}$ Região. Recurso Ex Officio no 94.01.34562-7, Relator: Des. Federal Eustáquio Silveira, da $4^{\mathrm{a}}$ Turma, Brasília, DF, 29 de março de 1995. Diário Oficial [da] República Federativa do Brasil, Brasília, DF, 27 abr. 1995. p. 24659). Cf., também, FRANCO, Alberto Silva; STOCO, Rui (Coord.). Código de Processo Penal e sua interpretação jurisprudencial. São Paulo: RT, 1999. v. 2, p. 3480. Apesar da controvérsia, neste estudo se considera vigente o artigo 748 do Código de Processo Penal, por duas razões. Primeira, para vivificar e materializar o efeito visível da reabilitação, ou seja, permitir o cancelamento da anotação referente à condenação na folha de antecedentes e a vedação da sua menção em certidões judiciais, efeito assegurado pelo artigo 93, caput, do Código Penal que concede "ao condenado o sigilo dos registros sobre seu processo e condenação", sem indicação legal do meio para alcançar esses resultados. Segunda, para assegurar ao juiz criminal o conhecimento da condenação reabilitada, medida não prevista, expressamente, pelos artigos 93 a 95 do Código Penal. Conhecer referida informação permitirá ao juiz e ao Ministério Público cumprirem o disposto no artigo 95 do Código Penal, norma antes disposta no artigo 750 do Código de Processo Penal, providenciando o cancelamento da reabilitação no caso de o reabilitado ser condenado como reincidente, por decisão definitiva, à pena diversa da multa.
} 
segredo, como indica o artigo 325, do Código Penal. Esse crime, se comparado àquele previsto no parágrafo $1^{\circ}$-A do artigo 153 , embora praticado por agente que tenha obrigação de sigilo em razão da função que ocupa, paradoxalmente, é punido de forma mais branda, com pena de detenção de 6 (seis) meses a 2 (dois) anos, ou multa, desde que o fato não constitua delito mais grave. ${ }^{19}$

Proporcionar segurança coletiva aos cidadãos é tarefa estatal importante, mas o cumprimento dessa missão não se liga à estrutura ou ao emprego do registro criminal, pois ele, por si só, não motiva ou inibe a criminalidade. Em outro sentido, todos os órgãos envolvidos na persecução penal devem atentar para as violações que o acesso aos dados do registro poderá causar à privacidade e aos efeitos à liberdade das pessoas, sem esquecer de que a magnitude das informações reunidas nesse arquivo justificou ao legislador penal brasileiro restringir a liberdade daquele que, ilegitimamente, divulgar dados do registro criminal.

\subsection{Aplicação do princípio da proporcionalidade}

Ultrapassada a abordagem da segurança e da liberdade no que concerne ao registro criminal, cabe referir agora ao princípio da proporcionalidade.

A proporcionalidade está assentada na obrigação do intérprete buscar justo equilíbrio quando deparar com interesses conflitantes.

O princípio da proporcionalidade também considerado como "postulado de interpretação sobre os limites de eficácia dos direitos fundamentais previstos na Constituição" 20 facilitará encontrar equilíbrio ${ }^{21}$ entre a segurança que deve pairar sobre as informações expedidas pelo registro diante do respeito à privacidade e à liberdade da

\footnotetext{
${ }^{19}$ A sanção fixada pelo legislador para o crime previsto no artigo 325 do Código Penal atenderá o critério da proporcionalidade se comparada à punição imposta para o crime de divulgação de segredo, tratado no parágrafo $1^{\circ}$-A do artigo 153 do Código Penal, somente no caso de ser possível demonstrar que da ação ou omissão resultar dano à Administração Pública ou a outrem, situação que permitirá ao juiz aplicar pena de reclusão, de 2 (dois) a 6 (seis) anos, e multa.

${ }^{20}$ ROSA, Fábio Bittencourt da. Proporcionalidade: perigo do conceito aberto. Boletim do IBCCrim, São Paulo, n. 153, p. 5, ago. 2005.

${ }^{21} \mathrm{O}$ equilíbrio que se pretende alcançar pela aplicação da proporcionalidade não deve ser confundido com ambigüidade, pois não tem esse significado. A ambigüidade, qualidade diversa do equilíbrio, é bem descrita na obra da escritora Lygia Fagundes Telles (Venha ver o pôr-do-sol \& outros contos. São Paulo: Ática, 1988. p. 29) no trecho do diálogo, a seguir transcrito, mantido entre os personagens Raquel e Ricardo: "Ah, Raquel, olha um pouco para esta tarde! Deprimente por quê? Não sei onde foi que eu li, a beleza não está na luz da manhã nem na sombra da noite, está no crepúsculo, nesse meio-tom, nessa ambigüidade. Estou lhe dando o crepúsculo numa bandeja e você se queixa."
} 
pessoa cujo nome e dados criminais foram inseridos nesse banco de dados.

A formulação doutrinária do princípio da proporcionalidade indica como pressuposto essencial formal para sua existência a legalidade e como pressuposto essencial material a justificação teleológica. O primeiro é sustentado pelo princípio da legalidade e revela que toda restrição a direito fundamental exige prévia disposição legal, emanada de órgão constitucionalmente competente, imposta e interpretada de modo estrito. O segundo demonstra ser possível limitar direito individual somente para dar efetividade a valores constitucionais relevantes. A doutrina também aponta a adequação (ou idoneidade), a necessidade (ou intervenção mínima) e a prevalência do valor protegido na ponderação dos interesses em confronto como requisitos intrínsecos (ou subprincípios) do princípio da proporcionalidade. Por fim, são requisitos extrínsecos do princípio da proporcionalidade a judicialidade e a motivação, significando que a medida restritiva de direitos deve ser imposta pelo juiz por intermédio de decisão motivada. ${ }^{22}$

No campo dos requisitos intrínsecos do princípio da proporcionalidade a adequação qualitativa, quantitativa e subjetiva impõe que a restrição do direito individual se mostre idônea para alcançar o resultado pretendido. A partir desse requisito, analisado sob seu tríplice aspecto, seguido pelos demais, é possível citar exemplos de situações relacionadas ao registro criminal que poderão ser interpretadas sob a luz desse princípio da proporcionalidade.

Ao analisar o requisito adequação como instrumento para limitar o acesso aos dados do registro criminal, entende-se faltar adequação qualitativa para conhecer anotação relativa à sentença penal absolutória, sem outra finalidade demonstrada, porque essa informação não serve para comprovar reincidência ou maus antecedentes criminais.

Da mesma forma, entende-se carente de adequação quantitativa a determinação da expedição de certidões relacionadas aos registros de atos infracionais relacionados à época de menoridade penal, com a finalidade de usá-los como argumento para exacerbar medidas ou sanções penais que possam ser impostas ao indivíduo depois de atingir 18 anos.

Por fim, no campo da adequação subjetiva, não se mostra idôneo deferir pretensão formulada pela acusação ou defesa para conhecer os dados do registro criminal das testemunhas que serão ouvidas na fase de instrução do processo criminal, visando indicar que a pessoa arrolada é ou não portadora de maus antecedentes penais e, portanto, a partir

\footnotetext{
${ }^{22}$ FERNANDES, Antonio Scarance. Processo penal constitucional. 3. ed. São Paulo: RT, 2002. p. 53-54.
} 
disso possa ser reduzida ou ampliada a credibilidade do testemunho. ${ }^{23}$

Seria adequado deferir acesso aos dados do registro criminal da testemunha no caso de a parte indicar de modo idôneo a existência de condenação relativa a crime que reduza a credibilidade das declarações da testemunha. Exemplo disso pode ser extraído por analogia do processo civil, na hipótese de suspeição da testemunha condenada pelo crime de falso testemunho. ${ }^{24}$ Entretanto, a possibilidade de qualquer pessoa ser condenada pela prática desse delito não justifica atender requerimentos esteriotipados da acusação e defesa formulados, sistematicamente, para vasculhar os antecedentes criminais das testemunhas arroladas pela parte contrária com o fim de buscar registro de condenação pela modalidade infracional antes indicada.

O requisito intrínseco seguinte do princípio da proporcionalidade, necessidade ou intervenção mínima recomenda que a opção escolhida deverá ser a que causar menos gravame ou dano. Sob esse requisito e dentro do tema registro criminal, admite-se menos gravoso solicitar informações acerca dos antecedentes criminais de acusado que seja servidor público ao órgão estatal encarregado dessa finalidade que ao seu chefe imediato, mesmo que tais referências estejam anotadas no prontuário individual desse servidor.

O emprego do último requisito intrínseco do princípio da proporcionalidade, a prevalência do valor protegido na ponderação dos interesses em confronto, permite sopesar os valores da "medida restritiva" e do "direito individual a ser violado", orientando pela prevalência do "valor de maior relevância". 25

No tocante ao acesso ao registro criminal, em linhas gerais, é possível interpretar esse subprincípio e afirmar prevalecer o direito à privacidade ao negar fornecer informações do registro criminal formulado por particular em relação a terceiros, se inexistir justa causa para deferir essa consulta, especialmente, no caso de o registro compilar informações que sequer sirvam para configurar reincidência ou antecedentes negativos.

Francisco Bueno Arús, ao entender que as anotações do Registro Central de Penados y Rebeldes devem ser temporalmente limitadas, tema que será desenvolvido neste

\footnotetext{
${ }^{23}$ Lecionou José Frederico Marques (op. cit., v. II, p. 310 e 313) que "a testemunha 'suspeita de parcialidade, ou indigna de fé' não está incapacitada de depor. Ela pode ser, apenas, objeto de contradita, para que, desse modo, o juiz, a final, possua elementos com que estimar o real valor de seu depoimento (cf. Código de Processo Penal, artigo 214)". Contradita, também com base na lição do mesmo autor, é incidente ocorrido durante o procedimento probatório no qual uma das partes comunica ao juiz os motivos do impedimento ou suspeição da testemunha.

${ }_{24}$ Artigo 405 , parágrafo $3^{\circ}$, inciso I, e parágrafo $4^{\circ}$ do Código de Processo Civil.

${ }^{25}$ FERNANDES, Antonio Scarance. Processo..., cit., p. 55.
} 
estudo mais adiante, afirma crer que a subsistência do efeito limitador de direitos causada pela referida inscrição, depois do cumprimento da pena, pode se justificar, unicamente, em critérios de prevenção geral (desaparecimento do alarma causado pelo delito, afirmação de confiança da opinião pública na proteção que dispensa a norma penal) e prevenção especial (superação do período de prova pelo delinqüente ressocializado). Entretanto, referindo-se ao princípio da proporcionalidade, o autor consigna não ser possível justificar a manutenção dessa anotação no registro sob o fundamento meramente retributivo "[...] pues, como opina el hombre medio con su idea natural de justicia, una vez pagado el delito, el principio de la proporcionalidad dejaría sin justificación el criterio de prolongar la privación de derechos del delincuente." 26

A partir dos exemplos mencionados, enfatiza-se que o requerimento para acesso ao registro criminal não estritamente relacionado à apuração dos antecedentes criminais do acusado deverá ser analisado e poderá ser indeferido por decisão judicial motivada, amparada no artigo 93, inciso IX, da Constituição Federal.

Esses referidos exemplos da aplicação dos requisitos sustentadores do princípio da proporcionalidade em relação ao registro criminal poderão sugerir entendimento de que eles atuam, sistematicamente, em favor do acusado no processo criminal. Entretanto, tais requisitos ou subprincípios não justificam interpretar-se conflito de regras sempre em favor do acusado, "mas verificar se a restrição é adequada, necessária e justificada pelo valor maior a ser protegido". 27

Assim, é possível deferir o acesso ao registro criminal existente em órgão responsável por essas informações localizado em Estado da Federação diverso daquele em que tramita a apuração criminal, bem como perante justiça especial federal ou estadual, desde que exista notícia idônea da residência ou permanência do acusado nesse local ou envolvimento em crimes cuja competência para o processo e julgamento seja da Justiça Eleitoral ou Militar. É admissível deferir esse tipo de requerimento, porque no Brasil o registro criminal mantido pelos órgãos estaduais, do Distrito Federal e da União é independente, e inexiste regra clara que determine a comunicação e anotação no registro criminal das decisões condenatórias dessas justiças especiais.

A apuração do crime, a aplicação da pena e a avaliação da necessidade de restringir a liberdade do acusado da prática de crimes são tarefas reservadas aos respectivos órgãos

\footnotetext{
${ }^{26}$ Op. cit., p. 24.

${ }^{27}$ FERNANDES, Antonio Scarance. Processo..., cit., p. 56.
} 
do Estado incumbidos de investigar, processar e julgar. Esses órgãos, no desempenho das suas funções, poderão empregar as informações contidas no registro criminal, devendo-lhes ser franqueados os dados nele inseridos, mas sua divulgação observará os limites legais.

Os dados protegidos pelo sigilo alcançado em razão da concessão de reabilitação criminal, por óbvio, não serão divulgados, exceto quando requisitados pelo juiz criminal, ${ }^{28}$ e aqueles relacionados aos processos encerrados que não resultaram em decisão condenatória não deveriam ser exteriorizados. Por fim, se cumprida a condenação ou extinta a pena, identicamente os respectivos dados do registro deverão manter-se sigilosos. $^{29}$

Além da proteção do sigilo, é preciso verificar a viabilidade da manutenção dessas informações no sistema de registro criminal diante da ofensa à privacidade e risco à liberdade que a divulgação indevida (ou não) dos antecedentes criminais poderá causar. Nesse contexto, cabe avaliar, também, a importância da autonomia do registro criminal em relação ao policial estabelecendo em cada um desses arquivos conteúdos compatíveis com a finalidade por eles buscada, abordagem específica a ser desenvolvida oportunamente.

O princípio da proporcionalidade ${ }^{30}$ auxiliará tratar eventuais ofensas à privacidade $\mathrm{e}$ riscos à liberdade que resultem do acesso e da divulgação dos dados do registro, facilitará encontrar posturas para o aperfeiçoamento desse sistema, além de evitar que nele haja intromissão indevida de pessoas não-autorizadas ou mesmo daquelas detentoras de permissão, mas que o vasculham para obter e divulgar informações de modo ilegítimo.

A proporcionalidade, portanto, apresenta-se como instrumento útil para auxiliar o desenvolvimento do registro criminal e deveria servir como fonte de orientação daqueles que o empregam, facilitando alcançar o "equilíbrio justo e razoável entre o interesse geral

${ }^{28}$ Artigo 748 do Código de Processo Penal.

${ }^{29}$ O artigo 202 da Lei $n^{\circ}$ 7.210, de 1983, dispõe que: "Cumprida ou extinta a pena, não constarão da folha corrida, atestados ou certidões fornecidas por autoridade policial ou por auxiliares da Justiça, qualquer notícia ou referência à condenação, salvo para instruir processo pela prática de nova infração penal ou outros casos expressos em lei."

${ }^{30}$ Ao discorrer a respeito da prova obtida mediante violação do sigilo das comunicações e de dados, Antonio Scarance Fernandes (Processo..., cit., p. 94-95) aponta que o princípio da proporcionalidade é o parâmetro orientador da sua obtenção a partir da quebra do sigilo de correspondência, de comunicação telegráfica e dos dados. Segundo o autor, a rígida interpretação da regra inserida no inciso XII do artigo $5^{\circ}$ da Constituição Federal indicaria que, à exceção da conversa telefônica, as demais formas de comunicação estariam protegidas de modo absoluto. Entretanto, ao discorrer sobre o tema, o professor demonstra que essa interpretação destoa da necessidade de equilibrar os bens protegidos pela Constituição Federal. Para sustentar sua idéia, busca amparo na regra do artigo 153 do Código Penal que pune a divulgação de segredo de correspondência sem justa causa. Desse modo, conclui que para aferir se há justa causa autorizadora da quebra do sigilo, é necessário manejar o princípio da proporcionalidade e verificar se existe "bem de maior valor do que o preservado pelo sigilo do segredo, desde que também esteja amparado constitucionalmente." 
da comunidade e a proteção dos direitos individuais."31

O emprego do princípio da proporcionalidade ficou reforçado no Brasil depois das alterações trazidas ao Código de Processo Penal pela Lei no 11.690, de 9 de junho de 2008. Entre as alterações feitas, ressalta-se aquela trazida pelo artigo 156, inciso I, que condicionou o juiz ao ordenar a produção de oficio de provas antecipadas e urgentes, observar a necessidade, adequação e proporcionalidade dessa medida.

É preciso disseminar a idéia de que a análise dos dados reunidos no registro criminal nunca deve sobrepujar a aferição da responsabilidade penal do agente, devendo o juiz "não ignorar o Homem Presente, não se conferindo unicamente relevância ao facto e homem passados, ao longo da nobre, mas simultaneamente, árdua tarefa de julgar.",32

Neste estudo, focado na análise do registro criminal, estará presente a concepção da busca do equilíbrio entre a preservação da privacidade e liberdade do indivíduo e a eficiência estatal na persecução penal, com a finalidade de proporcionar merecida segurança ao corpo social sem afrontar imotivadamente a liberdade de cada indivíduo que o integra, porque é abusivo restringir a liberdade sem objetivar a paz social.

\subsection{Equilíbrio entre eficiência e garantismo}

A passagem do processo inquisitorial para o processo de estrutura eminentemente acusatória assegurou aos acusados exercitaram as garantias da defesa e proporcionou deixar o Estado de Direito formal para ingressar em um Estado de Direito que se pretende seja material, democrático e social, com o fim de proteger a liberdade e a igualdade e dar aos referidos valores conteúdo material. O sistema processual acusatório ganhou visibilidade e expressão na Inglaterra por intermédio da Magna Carta Libertatum, de 1215, e do Bill of Rights, de 1689, enquanto na Europa Continental se instalou com o Iluminismo e a Revolução Francesa. Como conseqüência dessa evolução, mais recentemente, as Constituições modernas preocuparam-se com a defesa dos acusados diante do poder acusatório estatal, buscando eliminar o arbítrio e permitir a defesa da segurança e justiça nas relações mantidas entre o cidadão e o Estado. Nesse quadro, constata-se existir tensão

31 GASPAR, António Henriques. Os novos desafios do processo penal no século XXI e os direitos fundamentais (um difícil equilíbrio). Revista Portuguesa de Ciência Criminal. Coimbra, ano 15, n. 2, p. 257275, abr./jun. 2005.

${ }^{32}$ VEIGA, Catarina. Considerações sobre a relevância dos antecedentes criminais do argüido no processo penal. Coimbra: Almedina, 2000. p. 142. 
entre os interesses do indivíduo e aqueles almejados pelo Estado e sociedade, impondo acomodar a proteção da pessoa, o princípio da defesa da dignidade humana e o princípio da presunção de inocência ao lado da busca da verdade, realização da justiça e eficácia da administração da justiça penal. ${ }^{33}$

O processo penal possibilita ao Poder Judiciário, órgão estatal legitimado para julgar autores de crimes, o exercício da atividade jurisdicional criminal. Referida atividade serve para buscar a solução mais justa ao caso examinado e desenvolve-se debaixo das regras do devido processo legal, asseguradas de modo expresso pelo artigo $5^{\circ}$, inciso LIV, da Constituição Federal. Dessa garantia, mais recentemente, destacou-se o devido processo penal. $^{34}$

Ada Pellegrini Grinover aponta que no mundo todo, na América Latina e em especial no Brasil, foram detectados como valores do moderno processo penal o garantismo e a eficiência os quais não são colidentes e encontram no território nacional subsídios extraídos da Constituição Federal de 1988. O texto constitucional harmoniza esses dois valores ao enfatizar as garantias individuais e buscar eficiência para reprimir a criminalidade violenta e organizada que atemoriza a população e desafia o Estado. ${ }^{35}$

Como exemplo dessa harmonização é possível mencionar a inadmissibilidade processual das provas obtidas por meio ilícito (artigo $5^{\circ}$, inciso LVI) ${ }^{36}$ e a inafiançabilidade e insuscetibilidade de graça ou anistia aos crimes de tortura, tráfico ilícito de entorpecentes e drogas afins, terrorismo e definidos como hediondos (artigo $5^{\circ}$, inciso XLIII, ambos da Constituição Federal). Nota-se neste ponto equilíbrio da Constituição Federal, pois ao mesmo tempo que veda o emprego processual das provas ilícitas, endurece no trato aos acusados por crimes graves.

Entende, também, Ada Pellegrini Grinover, que o garantismo e a eficiência são valores fundantes do novo processo penal latino-americano e que o primeiro deve ser visto sob os enfoques subjetivo e objetivo, ao passo que o segundo precisa ser analisado sob dois desdobramentos. O garantismo se traduz, no primeiro aspecto, como a preservação dos direitos públicos das partes, em especial da defesa e, no segundo, como o justo processo e o exercício jurisdicional correto. A eficiência, ainda segundo a autora, observa-se mediante a

\footnotetext{
${ }^{33}$ VEIGA, Catarina, op. cit., p. 29-33.

${ }^{34}$ FERNANDES, Antonio Scarance. Processo..., cit., p. 31 e 44.

${ }^{35}$ Lineamentos gerais para o novo processo penal na América Latina; Argentina, Brasil e Código Modelo para Ibero-América. Revista de Processo, São Paulo, v. 15, n. 58, p. 121-134, abr.jun. 1990.

${ }^{36}$ A Lei no 11.690 , de 9 de junho de 2008, que deu nova redação ao artigo 157 do Código de Processo Penal, tratou da inadmissibilidade das provas ilícitas e de outros temas relacionados ao assunto.
} 
efetividade do processo penal para atender a persecução penal e por meio da eficácia dos direitos fundamentais preservados pelo próprio processo penal. ${ }^{37}$

O garantismo é expressão aberta utilizada para exprimir idéias variadas. Na obra Diritto e ragione: teoria do garantismo penale, Luigi Ferrajoli estuda a teoria do garantismo penal, modelo de direito calcado na estrita observância do Estado de Direito, cujo objetivo maior é contribuir para "a construção de uma sociedade (verdadeiramente) aberta, plural e multicultural",38

Seguindo a lição de Antonio Scarance Fernandes, inspirada nos ensinamentos de Ada Pellegrini Grinover, adota-se a posição de que o garantismo é a efetivação do devido processo legal sob dois aspectos. O primeiro é subjetivo e traduz-se na garantia das partes, enquanto o segundo é objetivo e funda-se nas garantias do justo processo. Menciona também o primeiro autor citado ser possível entender a eficiência e o garantismo como "valores fundamentais do processo penal moderno". 39

Quanto ao registro criminal, as idéias de eficiência e garantismo proporcionarão ajustamento difícil, mas indispensável, resultado do seguinte balanço: de um lado, firma-se a busca da defesa da sociedade em relação aos criminosos, mediante métodos como a intimidação geral e a segregação, enquanto do outro se posiciona a concepção de força da ressocialização do condenado e da redução da estigmatização gerada pelo registro. ${ }^{40}$

As normas que regem o registro criminal e os antecedentes sujeitam-se às idéias de reintegrar o acusado à sociedade e atender o interesse social de manter e ampliar o controle social em relação ao acusado. ${ }^{41}$

Esses pensamentos, pelo antagonismo que representam, deverão incidir no registro criminal simultaneamente, mas em sentidos opostos. É possível optar por uma vertente em detrimento da outra, mas em razão da magnitude do interesses em confronto, é esperado que essas pressões sejam assimiladas e proporcionem equilíbrio ao sistema do registro, evitando seja inviabilizada a reintegração do condenado à sociedade ou o controle que esta, de modo geral, pretende exercer sobre aquele.

\footnotetext{
${ }^{37}$ Lineamentos..., cit., p. 134.

38 WANDERLICH, Alexandre. Sociedade de consumo e globalização: abordando a teoria garantista na barbárie. (Re)afirmação dos direitos humanos. In: CARVALHO, Salo de; WANDERLICH, Alexandre (Orgs.). Diálogos sobre a justiça dialogal: teses e antíteses sobre os processos de informalização e privatização da justiça penal. Rio de Janeiro: Lumem Juris, 2002, p. 37-38.

${ }^{39}$ FERNANDES, Antonio Scarance. Procedimento..., cit., p. 34-35.

${ }^{40}$ COSTA, António Manuel de Almeida. O registo criminal. Coimbra: Gráfica de Coimbra, 1985. p. 192193.

${ }^{41}$ GROSSO GALVAN, Manuel. Los antecedentes penales: rehabilitación y control social. Barcelona: Bosch, 1983. p. 10.
} 
Passando para a análise da eficiência, é importante ressaltar que ela é um dos princípios reitores da administração pública brasileira ${ }^{42} \mathrm{e}$, em relação ao tema estudado, pode ser traduzida como o fornecimento seguro e rápido da informação desejada quanto à existência de anotações no registro criminal, especialmente, daquele apontado como autor de crime.

Sob a ótica do acusado, a Emenda Constitucional $n^{0} 45$, de 08 de dezembro de 2004, acrescentou o inciso LXXVIII ao artigo $5^{\circ}$ da Constituição Federal e assegurou a todos a duração razoável do processo, no âmbito judicial e administrativo, com os meios garantidores da celeridade da tramitação processual. A duração razoável do processo e celeridade no seu andamento exteriorizam o valor da eficiência processual desejada pela alteração constitucional.

A eficiência, também exigida do sistema de registro criminal, não é alcançada somente pelo fornecimento automático da informação criminal relativa à determinada pessoa, mas especialmente pela aferição do cabimento da oferta dessa informação ao solicitante e da necessidade dele obtê-la.

Em outras palavras, o sistema de registro deve ser dotado de mecanismo que permita controlar quem acessou os dados de terceira pessoa e também capaz de vedar consulta, caso o solicitante não reúna condições para obter essa informação. $O$ acesso também deverá ser recusado, mesmo que o solicitante tenha status suficiente para realizálo, se não indicar o fundamento dessa consulta, situação que poderá ocorrer quando o juiz criminal, o representante do Ministério Público ou os membros da Polícia desejarem obter informações reunidas no registro sem relacionar o acesso pretendido à existência de investigação ou processo para, por exemplo, atender interesse desvinculado da apuração ou julgamento do fato criminoso.

Assim, se a sociedade espera eficiência dos serviços públicos, tanto que esse princípio foi incorporado pela Constituição Federal, é natural que ela também deseje eficiência dos órgãos do Estado no momento da apuração dos crimes e da prestação jurisdicional. Para atingir esse resultado, o registro criminal deve estar preparado para fornecer, de modo rápido e seguro, as informações nele compiladas sem expor de modo indevido a privacidade daquele cujos dados criminais estão armazenados nesse sistema.

A análise etimológica realizada por Antonio Scarance Fernandes permite melhor compreender que a eficiência "expressa a capacidade, a força, o poder de algo que o leva a

${ }^{42}$ Artigo 37, caput, da Constituição Federal. 
produzir um efeito", a eficácia é a "qualidade do resultado produzido por algo" e a efetividade "corresponde ao atingimento de determinadas finalidades". Mais adiante, o autor relaciona a eficiência no processo penal com a finalidade que lhe é atribuída, salientando as correntes fundamentais que tratam da finalidade do processo penal. A primeira delas visa "assegurar a defesa do acusado", a seguinte "permitir aos órgãos da persecução penal a apuração da verdade e a punição dos autores de infrações penais" e a outra obter "resultado justo que se legitime pelo procedimento adequado". O estudo revela que a eficácia no processo dependerá da finalidade fixada, enquanto a efetividade, independentemente da finalidade buscada, é analisada "em razão dos efeitos positivos produzidos no meio social", a partir do que se espera do processo criminal, citando a "paz social, vigência de um Estado Democrático de Direito, segurança pública, preservação da dignidade humana" como valores meta. Por fim, aponta que a eficiência no processo penal é "a capacidade de um ato, de um meio de prova, de um meio de investigação, de gerar o efeito que dele se espera." $" 43$

O registro criminal, empregado no campo processual penal durante a investigação, apuração e julgamento do crime com finalidade de demonstrar eventuais antecedentes criminais existentes em relação ao acusado para, por exemplo, caracterizar a reincidência ou os maus antecedentes, deve oferecer informações seguras, de modo rápido, sob pena de não atingir o objetivo e não desempenhar o seu papel no sistema processual penal.

Desse modo, eficiência e garantismo, vistos como critérios fundamentais e legitimadores do processo penal brasileiro moderno, devem refletir no tratamento, no emprego e na estrutura do registro criminal.

\subsection{Vida privada, sigilo e registro criminal}

No Estado de Direito a persecução penal se coloca no mesmo plano dos princípios fundamentais do processo penal. O interesse social de punir o culpado orienta-se por regras e princípios preservadores da liberdade e dignidade humanas ao mesmo tempo que busca seja a justiça administrada e aplicada corretamente. ${ }^{44}$

Ao confrontarem-se, intensamente, a defesa social e os direitos de liberdade, deverá

${ }^{43}$ Reflexões sobre as noções de eficiência e de garantismo no processo penal. In: ALMEIDA, José Raul Gavião de; MORAES, Maurício Zanoide de (Coord.). Sigilo no processo penal. Eficiência e garantismo. São Paulo: RT, 2008. p. 9-28.

${ }^{44}$ VEIGA, Catarina, op. cit., p. 26-28. 
o Estado sacrificar menos possível os direitos de personalidade do acusado, "pedra de toque de um sistema de liberdades públicas". 45

Os dados pessoais, entendidos como "informações relativas à pessoa física identificada ou identificável”, não estão suficientemente protegidos pela clássica definição da privacidade considerada como "direito de estar só". Manter-se isolado é insuficiente para proteger dados pessoais reunidos em cadastros, arquivos manuais ou informatizados, pois nesse campo é preciso ter em mente que o resguardo das informações exige encarar a privacidade de modo diverso, ou seja, como uma espécie de "privacidade dinâmica". Esse modo de entender a privacidade, embora sem a nomenclatura ora atribuída, mas com semelhante sentido, foi considerado como "o direito de o sujeito conhecer, controlar, endereçar e interromper o fluxo de informações que a ele dizem respeito". ${ }^{46}$

É inquestionável que as informações pessoais agrupadas em bancos de dados estarão disponíveis para emprego legítimo mediante acesso regular, tanto que não se contesta a utilização necessária dos dados reunidos no registro criminal para, por exemplo, comprovar a reincidência ou os maus antecedentes dos acusados.

Entretanto, emprego diverso e fora desse contexto, mesmo a título do exercício do direito de informação ou de ser informado, deveria ser controlado. ${ }^{47}$ A veiculação das informações extraídas do registro criminal deve ocorrer, portanto, se houver previsão legal, determinação judicial, autorização do interessado ou justa causa.

As garantias constitucionais da vida privada e da inviolabilidade dos dados previstas pelos incisos X e XII do artigo $5^{\circ}$ da Constituição Federal sustentam a idéia de restringir o acesso ao registro criminal fora dessas situações indicadas.

${ }^{45}$ GRINOVER, Ada Pellegrini; FERNANDES, Antonio Scarance; GOMES FILHO, Antonio Magalhães. As nulidades no processo penal. 8. ed. São Paulo: RT, 2004. p. 153.

${ }^{46}$ BATTAGLIA, Elisa; FEDERICO, Giacomo di. La carta dei diritti e la tutela della riservatezza. In:ROSSI, Lucia Sereno (Coord.). Carta del diritti fondamentali e costituzione dell'Unione Europea. Milano: Giuffré, 2002. p. 214-215.

47 José Paulo Sepúlveda Pertence, ex-Ministro do Supremo Tribunal Federal, afirma que: “A informação sobre a prática de um crime é lícita e o princípio da proteção à privacidade não se aplica em tal caso. O que deve valer é a liberdade de informação, desde que não se desrespeite a vida privada de uma pessoa" (MEIRELES, Andrei; JÚNIOR, Carlos Alberto. Opinião Suprema. Revista Época, São Paulo, n. 211, p. 1317, 3 jun. 2002). A partir dessa idéia, mas em sentido contrário, é possível entender que em nome da liberdade de informação não se justifica acessar o registro criminal e oferecer aos órgãos da imprensa para divulgação sensacionalista quaisquer referências do passado criminal de determinada pessoa, inclusive porque referida conduta poderá configurar crime de difamação, previsto no artigo 21 , $2^{\circ}$, da Lei $n^{\circ} 5.250$, de 1967, ("publicação ou transmissão, salvo se motivada por interesse público, de fato delituoso, se o ofendido já tiver cumprido pena a que tenha sido condenado em virtude dele"). A eficácia desse dispositivo, além de outros, está suspensa e sob análise do Supremo Tribunal Federal, diante de decisão exarada nos autos

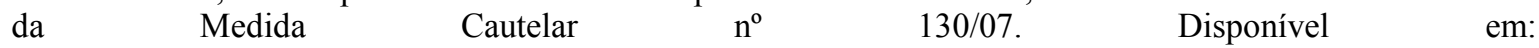
http://www.stf.jus.br/portal/jurisprudencia/listarJurisprudencia.asp?s1=medida $\% 20 \mathrm{e} \% 20130 \% 20 \mathrm{e} \% 202007$ \&base=baseAcordaos. Acesso em: 13 dezembro de 2008. 
Reafirma-se que o registro criminal é o repositório das informações individualizadas criado e mantido pelo poder público, especialmente a partir dos dados extraídos dos processos criminais. Em relação aos processos e aos atos processuais vige a regra da publicidade, restringível somente pela lei para defesa da privacidade ou do interesse social assegurada pelo inciso LX do artigo $5^{\circ}$ da Constituição Federal.

Todavia, é possível entender que a publicidade não alcança integralmente os dados do registro criminal pelos motivos a seguir expostos.

Primeiro, porque acessar o registro criminal para dele obter informação não é ato processual. $^{48}$

Segundo, porque a publicidade dos atos processuais visa proteger o cidadão dos excessos causados pelos processos secretos, permitindo-lhe fiscalizar a distribuição da justiça, ${ }^{49}$ finalidade que se inverte no caso do registro criminal, pois quanto maior a amplitude do acesso aos dados menos protegido estará o indivíduo.

Terceiro, porque, estando as condenações criminais sofridas por determinada pessoa reunidas em cadastro único e individualizado, será possível localizar esses dados com maior facilidade do que se eles estiverem distribuídos no sistema de justiça criminal, justificando por essa razão a restrição do acesso ao registro criminal.

Em Portugal, nota-se preocupação para proteger dados pessoais informatizados e controlar a quantidade crescente de decisões sujeitas à inscrição no registro criminal, pois referidos argumentos foram fixados como objetivos e orientaram a edição do Decreto-Lei n $381 / 98$, de 27 de Novembro, que "regulamenta e desenvolve o regime jurídico da identificação criminal e de contumazes" e "regula o funcionamento do registro criminal". 50

Para reforçar a importância da idéia de controlar e restringir o acesso aos dados do registro criminal, cabe frisar que, em 28 de janeiro de 1981, representantes dos EstadosMembros do Conselho da Europa, reunidos em Estrasburgo, firmaram a Convenção $108^{51}$ que forneceu orientações para proteger as pessoas do tratamento automatizado dos dados de

\footnotetext{
${ }^{48}$ Ao estudar fato e ato processual, fixou-se que este é "toda conduta dos sujeitos do processo que tenha por efeito a criação, a modificação ou extinção de situações jurídicas processuais”, apresentando-se como exemplos de ato processual o oferecimento de uma denúncia ou de uma petição inicial, um interrogatório e uma sentença (CINTRA, Antonio Carlos de Araújo; GRINOVER, Ada Pellegrini; DINAMARCO, Cândido Rangel. Teoria geral do processo. 13. ed. São Paulo: Malheiros, 1997. p. 336).

${ }^{49}$ FERNANDES, Antonio Scarance. Processo..., cit., p. 68.

${ }^{50}$ Diário da República I, 27 nov. 1998, Série-A, n. 275, p. 6.576. Disponível em: <http://www.dre.pt>. Acesso em: 23 jun. 2008.

${ }^{51}$ ASSOCIAÇÃO PARA O DESENVOLVIMENTO DO TELETRABALHO. Convenção n $\mathrm{n}^{\circ} 108$ do Conselho da Europa. Disponível em: <http://www.apdt.org/guia/L/Ldados/108.htm>. Acesso em: 19 nov. 2007.
} 
caráter pessoal.

$\mathrm{O}$ artigo $3^{\circ}$ dessa Convenção, inserido no capítulo I, que cuidou das disposições gerais, tratou dos campos da aplicação do texto e dispôs que ele também abrangia os dados dos ficheiros ou arquivos não-automatizados.

No capítulo II, ao fixar os princípios básicos para a proteção dos dados, o artigo $6^{\circ}$ trouxe norma que equiparou as informações relacionados às condenações penais aos demais dados considerados pelo texto da Convenção. ${ }^{52}$

A partir do conteúdo dos artigos destacado na Convenção 108, do Conselho da Europa, é possível considerar o registro das condenações criminais como dados merecedores de proteção e, portanto, "dados sensíveis". Essas informações, tais quais outras relacionadas à vida privada também consideradas "dados sensíveis", compõem aquilo que foi chamado de "núcleo duro" da privacidade. Em reforço à idéia, é importante ressaltar um julgado da Corte Européia de Estrasburgo que, ao tratar de tema correlato, entendeu restrito e utilizável exclusivamente aos fins para os quais se destinavam os dados compilados pela polícia e assegurou "o direito a que os dados reunidos em um registro policial não fossem utilizados para fins diversos daqueles para os quais foram recolhidos". 53

Em síntese, a normativa européia mencionada e o entendimento que a partir dela foi construído pela doutrina e jurisprudência referidas mostram a importância dos dados de caráter pessoal relativos às condenações criminais.

Francisco Bueno Arús também considera que o Registro de Antecedentes Penales contém, induvidosamente, "dados sensíveis" que, portanto, são merecedores de toda proteção necessária, justificando essa concepção na afirmação que "los bienes jurídicos sobre los que recaen las resoluciones judiciales amparadas en la normativa penal y procesal penal se refieren a las libertades públicas, los derechos fundamentales de las personas físicas y el honor e intimidad personal y familiar". 54

O relevo dos dados reunidos pelo registro criminal no Brasil permite visualizar que

\footnotetext{
52 "Artigo $6^{\circ}$ - Categorias especiais de dados: Os dados de carácter pessoal que revelem a origem racial, as opiniões políticas, as convicções religiosas ou outras, bem como os dados de carácter pessoal relativos à saúde ou à vida sexual, só poderão ser objecto de tratamento automatizado desde que o direito interno preveja garantias adequadas. O mesmo vale para os dados de carácter pessoal relativos a condenações penais" (ASSOCIAÇÃO PARA O DESENVOLVIMENTO DO TELETRABALHO. Convenção $\mathrm{n}^{\circ} 108$ do Conselho da Europa. Disponível em: <http://www.apdt.org/guia/L/Ldados/108.htm>. Acesso em: 19 nov. 2007.

${ }^{53}$ BATTAGLIA, Elisa; FEDERICO, Giacomo di, op. cit., p. 208 (nota de rodapé 6: Sentença Leander c. Suécia, 26 mar. 1987, Série A, n. 116) e 215.

${ }_{54}$ Op. cit., p. 69-61.
} 
a legislação nacional deveria tratar como sigiloso o seu conteúdo e regular-lhe o acesso, seja o arquivo manual ou informatizado. Essa postura evitaria o fornecimento das informações violadoras do sigilo dos dados pessoais e ofensivas à vida privada das pessoas cujos nomes e condenações estejam nele inscritos.

Ao comentar sobre vida privada e cadastros, Tércio Sampaio Ferraz Júnior afirma que o risco à integridade moral do sujeito, protegida pela direito à privacidade, situa-se na apropriação de dados que não dizem respeito a terceiros, tanto que para o autor pensar de outro modo tornaria impossível acessar o registro de comércio, o registro de empregados, o registro de navio etc, porque isso seria uma "proteção absurda à privacidade". 55

A idéia defendida pelo referido autor confirma a linha de pensamento seguida e reforça entender que o acesso ao registro criminal para fins legítimos não caracteriza violação à vida privada da pessoa, embora esse acesso será indevido quando terceiros nãointeressados conhecem, manuseiam e veiculam informações contidas nesse banco de dados. Essa prática deve ser vedada e os responsáveis por ela punidos, providências úteis para desestimular a intromissão indevida nos dados armazenados nos arquivos criminais e a violação da privacidade alheia.

A vida privada da pessoa é protegida pelo sigilo das informações contidas no registro criminal. ${ }^{56}$ Mesmo sem o ordenamento jurídico nacional dispor, expressamente, acerca do caráter sigiloso do registro criminal, é necessário interpretá-lo com essa característica sob pena de desvirtuar-lhe o emprego, permitir acessos ilegítimos e violadores da privacidade alheia, exacerbando seu papel estigmatizante, característica que a modernidade exige redução máxima.

A legislação brasileira aponta que o registro criminal será sigiloso no caso da

55 Sigilo de dados: o direito à privacidade e os limites à função fiscalizadora do Estado. Sigilo fiscal e bancário. In: COSTA, José de Faria; SILVA, Marco Antonio Marques da. Direito penal especial, processo penal e direitos fundamentais: visão luso-brasileira. São Paulo: Quartier Latin, 2006. p. 449-450.

${ }_{56}$ Cleunice A. Valentim Bastos Pitombo (Considerações sobre a tutela da intimidade e vida privada no processo penal. Revista Brasileira de Ciências Criminais, RT, São Paulo, n. 26, p. 63, abr.jun. 1999) afirmou que: “Ao menos entre nós, a rigor, 'vida privada' é mais ampla, ou abrangente do que 'intimidade' e a sinonímia emerge remota. O que se nota, entretanto, nos estudos, é o uso de expressões intimidade e vida privada como se fossem sinônimas. A semântica, porém, auxilia a compreensão do tema." Mais adiante, com base na lição de Ivete Senise Ferreira, a autora ressalta que "o termo 'vida privada' é mais amplo, com características propiciadas, pela doutrina francesa que considera a intimidade uma esfera mais restrita do direito à vida privada". Não é feita distinção nesse texto entre os termos "vida privada" e "privacidade", utilizando-os, indistintamente, em virtude da semelhança das idéias que exprimem e do seu uso indistinto pela doutrina. Entretanto, neste trabalho se adota entendimento de que entre as diversas esferas da personalidade as informações armazenadas no registro criminal estão relacionadas à vida privada e, portanto, protegidas do acesso indiscriminado pela norma inscrita no artigo X do artigo $5^{\circ}$ da Constituição Federal. 
concessão da suspensão condicional da pena ${ }^{57}$ e da reabilitação criminal, ${ }^{58}$ efeito que se estende ao registro policial, pois se restringe à expedição de atestado de antecedentes na hipótese de arquivamento de inquérito policial, salvo se existir condenação, conforme dispõe o parágrafo único do artigo 20 do Código de Processo Penal. ${ }^{59}$

Esses dispositivos, embora não específicos, singelos e pontuais, permitem interpretar que o registro criminal deve ser sigiloso. ${ }^{60}$

Referida interpretação não destoa de outras normas legais, porque não há regra legislativa que disponha ser o registro público, além de proteger a vida privada das exposições desnecessárias e indesejáveis, valor garantido pelo texto constitucional e, ainda, atender os interesses sociais e da justiça, pois ressalva o fornecimento de certidões do registro a partir das requisições judiciais e do Ministério Público.

O registro criminal, portanto, deve ser visto como sistema de informações criminais protegido por sigilo intrínseco e próprio, isto é, a informação nele contida é reservada e fornecida somente se forem cumpridas determinadas exigências e condições, por exemplo, responder requisição judicial para instruir processo-crime ou fornecer informação a partir do requerimento do próprio interessado.

Entretanto, em determinadas situações, por determinação legal extraordinária, por vezes ratificada por ordem judicial individualizada ou simples reflexo do texto legal, os dados inseridos no registro criminal ganham proteção extrínseca. Essa proteção é reforçada

${ }^{57}$ Artigo 709, parágrafo $2^{\circ}$, do Código de Processo Penal e artigo 163, parágrafo $2^{\circ}$, da Lei $\mathrm{n}^{\mathrm{o}} 7.210$, de 1984 (Lei de Execução Penal). Conforme Manuel Grosso Galvan (op. cit., p. 119), a Ley, de 17 de octubre de 1908, determinou o envio das informações relativas às condenações ao Registro Central, incluindo a obrigação de também remetê-las mesmo em caso de suspensão da condenação. Até então, na Espanha, não se incluíam no registro as condenações suspensas diante da relação dessa anotação com o registro de prisões e por entender-se que a pessoa capaz de gozar suspensão da condenação não deveria ser submetida a controle posterior por meio dessa anotação no registro. Quase cem anos atrás, portanto, o legislador espanhol notou a relação entre inserção do nome no registro e presunção de tratar-se de alguém que esteve preso, bem como, visualizou que a anotação da condenação no registro, mesmo suspensa, gerava posterior controle social e causava estigmatização da pessoa.

${ }_{58}$ Artigo 748 do Código de Processo Penal e artigo 202 da Lei n ${ }^{\circ}$ 7.210, de 1984 (Lei de Execução Penal).

59 “Art. 20 - A autoridade assegurará no inquérito o sigilo necessário à elucidação do fato ou exigido pelo interesse da sociedade.

Parágrafo único. Nos atestados de antecedentes que lhe forem solicitados, a autoridade policial não poderá mencionar quaisquer anotações referentes a instauração de inquérito contra os requerentes, salvo no caso de existir condenação anterior."

${ }^{60}$ PRADO, Luiz Regis; BITENCOURT, Cezar Roberto. Código Penal anotado e legislação complementar. São Paulo: RT, 1997. p. 405. A Procuradoria-Geral de Justiça do Estado de São Paulo publicou no dia 17 de junho de 2005, no Diário Oficial do Poder Executivo, o Aviso no 321/05-PGJ, comunicando a aprovação da Tese $n^{\circ}$ 212, do Setor de Recursos Extraordinários e Especiais Criminais, redigido da seguinte forma: “ANTECEDENTES CRIMINAIS - EXCLUSÃO DE DADOS DOS INSTITUTOS DE IDENTIFICAÇÃO IMPOSSIBILIDADE. A lei assegura o sigilo dos cadastros criminais, nas hipóteses de arquivamento de inquérito, absolvição, reabilitação e extinção da punibilidade, salvo requisições judiciais ou casos expressos em lei. Tais dados, portanto, não podem ser excluídos dos terminais dos Institutos de Identificação." 
mediante ordem judicial e impede a revelação desses dados, como ocorre no caso da condenação reabilitada e do condenado ao cumprimento de pena com sursis, ou ainda, por interpretação singela do texto da lei na hipótese daquele condenado cuja pena foi extinta ou cumprida.

A proteção da vida privada proporcionada pelo sigilo do registro, excetuados os casos de acesso regular, é valor a partir do qual todo o sistema de armazenamento desses dados deve ser visto e fundadas as iniciativas para sua estruturação. Essa opção resulta da interpretação analógica de outros dispositivos legais que impõem sigilo ao registro no caso de suspensão condicional do processo e de reabilitação, da inexistência de orientação para tratar como públicos os dados do arquivo que contém esses registros e, especialmente, da consonância da posição com a norma do inciso $\mathrm{X}$ do artigo $5^{\circ}$ da Constituição Federal brasileira que considera inviolável a vida privada e assegura direito à indenização pelo dano material ou moral decorrente de sua violação.

\subsection{Contraditório, presunção de inocência e registro criminal}

O contraditório, "ciência bilateral dos atos e termos do processo e possibilidade de contrariá-los", 61 liga-se intimamente ao direito de defesa e visa proporcionar equilíbrio entre acusação e defesa. ${ }^{62}$

No processo penal o acusador e o defensor com freqüência debatem informações relacionadas aos antecedentes criminais do acusado. O registro criminal e as certidões dele extraídas, normalmente, são as fontes dessas informações. ${ }^{63}$

Evita-se ou minimiza-se a interpretação indevida dos mencionados antecedentes pela observância estrita do contraditório, facultando-se às partes conhecerem e terem oportunidade de contrariar o conteúdo de toda informação, extraída do registro e juntada aos autos do processo, que esteja relacionada aos antecedentes do acusado, especialmente se essa informação for empregada para vedar benefícios, motivar aumento ou permitir

${ }^{61}$ ALMEIDA, Joaquim Canuto Mendes de. Princípios fundamentais do processo penal. São Paulo: RT, 1973. p. 82.

${ }^{62}$ FERNANDES, Antonio Scarance. Processo..., cit., p. 266-268.

${ }^{63} \mathrm{O}$ indeferimento do pedido para obter certidões relativas à vida pregressa do acusado foi considerado cerceamento do direito de acusação e deu causa à anulação de processo-crime, conforme antigo acórdão do extinto Tribunal de Alçada Criminal de São Paulo (BRASIL. Tribunal de Alçada Criminal. Processo $n^{\circ}$ 36.715, Relator: Francis Davis, da $4^{\text {a }}$ Câmara, São Paulo, SP, 18 de maio de 1972. Por maioria de votos. Revista dos Tribunais, São Paulo, n. 448, p. 389, fev. 1973). 
qualquer outra forma do recrudescimento da pena ou do regime prisional impostos.

As partes podem produzir prova documental a qualquer momento sob pena de cerceamento de direito e, também, podem manifestar-se sobre os documentos juntados, mesmo encerrada a instrução. Impossibilitar manifestação da defesa acerca de certidão de antecedentes criminais do acusado após finda a instrução serviu como fundamento para anular sentença condenatória. ${ }^{64}$

A idéia de reservar a apreciação e o conhecimento integral do conteúdo do registro criminal para depois da audiência de instrução, ou seja, logo a seguir à produção da prova relacionada ao fato, ${ }^{65}$ embora pretenda impedir o julgador de conhecer, antecipadamente, dos antecedentes do acusado, não preserva integralmente o contraditório, especialmente se atribuir ao juiz, isoladamente e sem intervenção das partes, a tarefa de analisar os antecedentes criminais do acusado.

Apesar de essa idéia buscar a paridade entre acusação e defesa e pretender ampliar a imparcialidade e objetividade do julgador, a proposta, comum ao sistema anglo-saxão, ${ }^{66}$ necessitaria ser mais bem explicitada para evitar risco de reduzir a possibilidade de as partes influenciarem a convicção judicial, especialmente quanto aos antecedentes criminais do acusado, reservando a elas papel ativo nessa fase do julgamento que culmina com a fixação da pena. ${ }^{67}$

Prosseguindo nas reflexões sobre alguns aspectos do direito de defesa e o emprego do registro criminal, considera-se que o conteúdo do princípio da presunção de inocência tem valor intraprocessual e extraprocessual, porque proíbe a inversão do ônus da prova contra o acusado e impede que as autoridades do Estado, "qualquer que seja a circunstância, declare, considere ou sugira uma pessoa como culpada antes que a

${ }^{64}$ GRINOVER, Ada Pellegrini; FERNANDES, Antonio Scarance e GOMES FILHO, Antonio Magalhães. $A s$ nulidades..., cit., p. 200-201. Ver, especialmente, menção ao acórdão do Tribunal de Justiça do Rio Grande do Sul que considerou nula a sentença que apreciou os antecedentes do acusado para fins de condenação, após as alegações finais, sem possibilitar manifestação da defesa (BRASIL. Tribunal de Alçada. Apelação $\mathrm{n}^{\circ}$ 290099860, Relator: Luiz Gonzaga Pila Hofmeister, da $1^{\text {a }}$ Câmara Criminal, Rio Grande do Sul, RS, 10 de outubro de 1990. Revista dos Tribunais, São Paulo, ano 80, v. 665, p. 329-330, mar. 1991).

${ }^{65}$ VEIGA, Catarina, op. cit., p. 133.

${ }^{66}$ Ao estudar a cesura no juízo penal e tratar das vantagens e desvantagens da adoção desse método bifásico, no qual depois de julgar o fato e a responsabilidade penal do agente se discute a pena a ser imposta, foi sugerido que as garantias processuais do acusado e os princípios de atuação processual, sem prejuízo de pequenas variações, sejam preservados até o momento da finalização do procedimento (MAIER, Julio B. J. La cesura del Juicio Penal. Doctrina penal. Teoría y práctica en las ciencias penales. Depalma, Buenos Aires, ano 7, n. 26, p. 263, 1984).

${ }^{67}$ Francisco Bueno Arús (op. cit., p. 54) aponta que entre os múltiplos fatores que juiz e tribunal deverão ponderar para determinar a pena aplicável ao caso concreto, encontra-se em "la personalidad del reo o las circunstancias personales del reo [...] para cuya valoración ofrecen elementos importantes los antecedentes penales del interesado". 
culpabilidade esteja legalmente estabelecida". ${ }^{6}$

A partir dessa afirmação, especialmente em relação ao aspecto extraprocessual do princípio da presunção de inocência descrito, é possível asseverar, reforçando a necessidade de explicitar-se a proteção do sigilo de determinados dados contidos no registro, que o acervo das suas informações deve ser preservado dos acessos particulares em relação às anotações referentes aos inquéritos policiais arquivados, às decisões extintivas da punibilidade e aos processos criminais sem imposição de condenação.

A restrição de acesso aos mencionados dados do registro também é justificada pela presunção de inocência, especialmente, porque é comum o uso de informações dessa natureza em prejuízo da pessoa sugerindo que a notícia de envolvimento anterior com investigação ou processo para apurar eventual prática de crime, mesmo sem resultado desfavorável, indica fraqueza de caráter ou personalidade deturpada. ${ }^{69}$

Ainda em relação à presunção de inocência é importante não enxergar o registro criminal e as certidões dele extraídas como meios para provar ou fundamentar a culpa do acusado. Inegável admitir que os dados fornecidos pelo registro criminal podem auxiliar e orientar eficazmente o juiz ao fornecer informações relacionadas ao passado criminal do acusado e proporcionar caminhos para fixar a pena e orientar sua execução. Entretanto, o instituto não deverá servir de argumento para determinar a responsabilização penal do acusado. Além disso, já foi defendido que nele somente deveriam inscrever-se informações extraídas das sentenças penais condenatórias para preservar e prestigiar o princípio da presunção de inocência, devendo desse modo o conteúdo dos certificados extraídos do registro criminal restringir-se àquilo que se mostre necessário ao conhecimento para fins processuais e penais. $^{70}$

68 GASPAR, António Henriques. Os novos desafios do processo penal no século XXI e os direitos fundamentais (um difícil equilíbrio). Revista Portuguesa de Ciência Criminal, Coimbra, ano 15, n. 2, p. 264, abr./jun. 2005.

${ }^{69}$ Francisco Bissoli Filho (op. cit., p. 167) frisa que "O Código de Processo Penal, no seu artigo 41 [...] não obrigando o acusador a descrever circunstâncias do autor do crime, de tal sorte que a aceitação à influência dos antecedentes e da reincidência criminal, como circunstâncias do autor constitui grave lesão aos princípios da presunção de inocência (se os fatos considerados não resultaram de condenação transitada em julgado), do devido processo legal (se resultar da instauração de um processo legalmente instaurado) e da ampla defesa (se não foi oferecida oportunidade de defesa ao imputado, para que pudesse constestar a existência ou não da circunstância contra si levantada)."

${ }^{70}$ VEIGA, Catarina, op. cit., p. 60-61 e 68. Mais adiante, ao afirmar nessa obra (p. 87, em especial, ver nota de rodapé 128) que "a justiça humana é de tal modo precária que não só faz sofrer as pessoas depois de condenadas, como as faz sofrer para saber se hão-de ser condenadas. Ora, é em face desta realidade inelutável, mas nem por isso menos lamentável, que o princípio da presunção de inocência ganha nova luz: até à decisão final é sempre possível admitir a hipótese da absolvição. E se a absolvição ocorre por força de se ter afirmado a inocência do argüido, este tê-lo-á sido sempre", a autora mostrou o valor da presunção de inocência para o processo e o registro criminal. 
A inscrição do nome do condenado no registro, inegavelmente, gera estigmatização $^{71}$ e atribui-lhe status negativo, efeito e conceito freqüentes da avaliação social dessa pessoa. ${ }^{72}$

Essa avaliação prejudicial ao ex-condenado deve ser afastada do campo jurídico, especialmente na área processual penal, pois é essa a esfera própria para assegurar a liberdade do acusado e deve ser repelido o pensamento da verossimilhança das ações imputadas a ele, a partir do início da persecução penal, somente por ser detentor de antecedentes criminais.

É bastante ponderável a idéia de que no registro criminal, como repertório das informações relativas aos crimes praticados por determinada pessoa, devessem constar somente as anotações relativas às decisões em que ao acusado "é aplicada determinada sanção em virtude de resultar provada a sua culpa pela prática de determinados factos, ou seja, deveriam constar as decisões condenatórias transitadas em julgado." Concernente ao acusado absolvido nada deveria constar do registro criminal em relação ao processo que gerou essa decisão absolutória, por razões de política criminal e para evitar que essa anotação seja "potenciadora de pré-juízos negativos e estigmatizantes" referentes ao condenado. $^{73}$

No Brasil essa posição ainda não foi assumida, mas os efeitos negativos da anotação no registro criminal sem conteúdo condenatório poderiam ser atenuados estimulando-se a criação de mecanismos legais, simples e objetivos que permitam cancelar as anotações referentes a processos criminais que não resultaram na imposição de pena ou de medida de segurança.

Posição garantista e de acordo com a presunção de inocência foi adotada em Portugal, porque nesse país atualmente há enumeração legal das decisões judiciais que podem ser inscritas no registro criminal, ressalvando-se, expressamente, que a comunicação delas ocorre após o trânsito em julgado. ${ }^{74}$

Diante da análise do contraditório e da presunção de inocência perante o registro

\footnotetext{
${ }^{71}$ Francisco Bissoli Filho (op. cit., p. 190), ao iniciar o estudo da teoria dos estigmas, apontou, com base em observações feitas a partir de análises de outros autores, que estigma é palavra de origem grega empregada para definir a existência de sinal corporal que evidenciava algo de extraordinário ou mau em relação ao qualificativo moral de alguém. No seu nascedouro, o estigma era representado com cortes ou marcas causadas pelo fogo no corpo daquele que o portava visando mostrar que se tratava de escravo, criminoso ou traidor, ou seja, "pessoa marcada, ritualmente poluída, que devia ser evitada, principalmente em lugares públicos."

72 GROSSO GALVAN, Manuel, op. cit., p. 373.

${ }^{73}$ VEIGA, Catarina, op. cit., p. 90-91.

${ }^{74}$ Artigo 5º números 1 e 3, da Lei 57/98, de 18 de Agosto. Cf. VEIGA, Catarina, op. cit., p. 147-148.
} 
criminal, nota-se que referidas garantias devem ser relacionadas à estrutura e ao emprego dos dados fornecidos pelo referido instituto no campo processual penal para assegurar e ampliar o direito de defesa do acusado.

\subsection{Conceito e finalidade do registro criminal}

No idioma português utilizado no Brasil a palavra registro pode ser entendida como "uma inscrição oficial que gera efeitos legais". ${ }^{75}$ Criminal "diz respeito a crime, relativo ao julgamento dos crimes; trata de processo penal ou de tribunal ou jurisdição dos processos penais". ${ }^{76}$

A expressão registro criminal, quase sem emprego consignado na legislação processual ou penal brasileira, ${ }^{77}$ é encontrada no dicionário como "assentamento dos antecedentes criminais dos indivíduos processados, feito por um escrivão do juízo de direito em cada comarca". 78

No sentido técnico-jurídico, considera-se o registro criminal o "repertório das decisões de natureza penal proferidas pelas instâncias judiciárias do Estado"79 criado para exercer papel coadjuvante na administração da justiça ao oferecer informes relativos ao passado criminal da pessoa acusada. ${ }^{80}$

É um sistema de informações criminais organizado e instituído com o fim de demonstrar a quem se aplicou a Justiça que deve funcionar sob esquema de "grande simplicidade", mas "muito eficaz". ${ }^{81}$

Numa ótica objetiva e que privilegiou o interesse público e social de conhecer os dados inscritos no registro criminal sem preocupação com as conseqüências negativas do registro, foi considerado na Espanha que o registro é "arquivo de dados referentes a pessoas que delinqüiram, foram condenadas, respondem processo ou estão revéis, facilitando desse modo o conhecimento disso pelo Estado, organismos ou pessoas interessadas em obter

\footnotetext{
${ }^{75}$ BORBA, Francisco S. Dicionário de usos do português no Brasil. São Paulo: Ática, 2002. p. 1352.

${ }^{76}$ CRIMINAL. Disponível em: http://michaelis.uol.com.br/moderno/portugues/index.php?lingua=portuguesportugues\&palavra=criminal. Acesso em: 04 nov. 2007.

${ }_{77} \mathrm{O}$ artigo 84, parágrafo único, da Lei $\mathrm{n}^{\circ} 9.099$, de 1995, refere-se aos registros criminais.

${ }^{78}$ REGISTRO. Disponível em: http://michaelis.uol.com.br/moderno/portugues/index.php?lingua=portuguesportugues\&palavra=registro. Acesso em: 04 nov. 2007.

${ }_{79}$ DIAS, Figueiredo. Direito penal português: parte geral. Lisboa: Aequitas, 1993. v. II, p. 641 (parágrafo 1018).

${ }^{80}$ VEIGA, Catarina, op. cit., p. 60.

${ }^{81}$ GROSSO GALVAN, Manuel, op. cit., p. 127.
} 
informações sobre tais circunstâncias, tão importantes para o melhor desenvolvimento da vida em sociedade". ${ }^{82}$

Nota-se, portanto, que sobre o registro criminal no Brasil, embora seja ele instituto quase não referido pela lei, existe idéia geral, tanto que a expressão foi dicionarizada e ostenta o significado de cadastro elaborado pela Justiça no qual estão reunidos nomes das pessoas processadas.

Não se considera que a lei devesse conceituar o que é registro criminal, porque isso sequer foi feito com a identificação criminal tratada no Brasil pela Lei $\mathrm{n}^{\mathrm{o}}$ 10.054, de 2000 . Entretanto, a legislação poderia ser explícita em relação ao instituto e indicar as regras básicas para sua criação, manutenção e uso, observadas a Constituição Federal e as posições doutrinárias e as jurisprudenciais dominantes, sem desprezar referências ao direito comparado.

O fim elementar do registro é a conservação dos dados relativos ao passado judicial das pessoas condenadas, que deve ser instalada sobre uma base de dados efetiva, facilmente acessível à Administração da Justiça e aos demais interessados autorizados, ou seja, poderes públicos e particulares, no limite daquilo que lhes é permitido conhecer. Ao realizar análise profunda do instituto, diante do modo como o registro criminal é estruturado e empregado, afirmou Manuel Grosso Galvan que sua última finalidade é reduzir a inserção social das pessoas condenadas, não somente nos cargos abertos pela Administração Pública, mas em qualquer outra área importante, tratando-se de "sistema altamente evoluído de marginalização e controle social, que demonstra, permanentemente, que a condenação não extingue a responsabilidade penal ou, ao menos, suas conseqüências, já que o controle não deixa de utilizar nenhum dos instrumentos ao seu alcance". ${ }^{83}$

Entretanto, o registro não deve ser compreendido exclusivamente com o objetivo destacado pelo referido autor, mas para atender a finalidade específica para a qual foi idealizado, ou seja, servir de repositório das informações criminais colocadas a serviço da Justiça para emprego em situações definidas.

Ocorre que o largo lapso temporal de emprego do registro criminal para atender fins investigativos, judiciais e particulares sem preocupação com a preservação da vida privada das pessoas e visando satisfazer à pretensa eficiência investigativa ou judiciária, sem falar nos acessos para atender fins públicos diversos e até privados, deturpou o emprego desse

${ }^{82}$ G. Alférez Callejón, apud GROSSO GALVAN, Manuel, loc. cit.

${ }^{83}$ Op. cit., p. 129. 
instituto no País.

Essa visão sem foco do registro criminal lançada sobre ele pelos poderes, órgãos públicos e sociedade, não foi rechaçada pela estrutura administrativa que gerencia o sistema, normalmente ligada aos órgãos da Segurança Pública, possivelmente em razão do esboço que lhe foi proposto pelo Código de Processo Penal de 1941, "engendrado sob a lógica autoritária e repressiva do Estado Novo e confessadamente inspirado no modelo fascista italiano". 84

Não cabe afirmar se por descaso ou propositalmente o emprego do registro ultrapassou os fins para os quais ele foi criado. Trabalhar para empregar o registro criminal dentro da finalidade para a qual a doutrina lhe reservou poderá, para alguns, representar uma espécie de "ilusão sedutora e inatingível", mas apesar disso se considera necessário buscar a eficiência do sistema, sem indevida exposição da privacidade da pessoa.

Pressionado por argumentos diversos, tais como a necessidade administrativa ou social de conhecer eventuais envolvimentos criminais da pessoa simplesmente candidata ao preenchimento de vaga em grande número de empregos públicos e alguns de caráter privado, o acesso ao registro criminal permitiu atender outros interesses além daqueles legitimamente buscados pela Polícia e Justiça.

Reforço à idéia do uso irregular do registro, aplicável à realidade nacional, pode ser encontrado em outro trecho da obra de Manuel Grosso Galvan. O autor espanhol aponta que a disfuncionalidade do sistema jurídico penal atinge os antecedentes criminais e pode ser visualizada nesse instituto por meio do seu emprego desvirtuado, característica que o afasta das finalidades que deveria cumprir. ${ }^{85}$

Ao tratar da influência implícita dos "antecedentes" e da "reincidência criminal" no sistema penal brasileiro, Francisco Bissoli Filho afirma que o magistrado ou qualquer operador do sistema criminal não deveria fundamentar decisões a partir das informações extraídas dos mencionados institutos, ressaltando, entretanto, que os jurados, como juízes de fato que são, por encontrarem-se dispensados de "fundamentar as suas decisões estão muito mais sujeitos à mencionada influência". 86

Com o objetivo de reduzir os efeitos negativos da inobservância da finalidade do registro criminal é que se entende necessário estruturar seu sistema no Brasil. Em síntese,

${ }^{84}$ GOMES FILHO, Antonio Magalhães. Presunção de inocência e prisão cautelar. São Paulo: Saraiva, 1991. p. 61.

${ }^{85}$ Op. cit., p. 375-376.

${ }^{86}$ Op. cit., p. 110. 
essa estruturação deve permitir que o registro criminal alcance outra físionomia e seja sustentado por mecanismos que regulem a inserção dos dados e autorizem o cancelamento e a correção dessas informações, sem falar no controle e restrição ao acesso dos dados desse sistema.

Embora os dados obtidos do registro criminal tenham sido considerados como meio facilitador da demonstração da responsabilidade penal do acusado, ${ }^{87}$ caracterizando-se como uma "presunção particularmente pesada", resultado do conhecimento antecipado dessas informações pelo juiz antes mesmo da discussão da culpa, ${ }^{88}$ nota-se que essa afirmação está lastreada no aspecto subjetivo da avaliação feita pelo juiz criminal, porque objetivamente ele não deverá motivar decisão condenatória ou qualquer medida restritiva da liberdade na mera existência de antecedentes criminais desfavoráveis.

\subsection{Natureza do registro criminal}

Não há forma definida para tratar o registro criminal no Brasil no campo processual penal, o que permitirá explorar a idéia que ele serve, essencialmente, como meio de prova para a configuração da reincidência e da existência dos antecedentes criminais.

O registro criminal não deve servir como mero instrumento para o funcionamento destes institutos, ou seja, reincidência e antecedentes, porque visto sob essa ótica perderia a autonomia e assumiria caráter de neutralidade, dispensável ao ângulo de abordagem pretendido neste estudo. Busca-se aqui, outrossim, demonstrar a importância da sua manutenção e do seu aperfeiçoamento, discutir os pontos concretos do seu funcionamento e analisar sua necessária autonomia, também sem penetrar profundamente nas intrincadas questões de Direito Penal que porventura se entrelacem ao tema. ${ }^{89}$

Embora seja conveniente estudar o registro criminal como instituto autônomo, é

${ }^{87}$ Maria Thereza Rocha de Assis Moura (A prova por indícios no processo penal. São Paulo: Saraiva, 1994. p. 73), ao analisar a vida anterior, especificamente, no que toca à capacidade moral para delinqüir, afirma que "o indício será mais forte quando o imputado tenha cometido vários delitos da mesma espécie, nas mesmas circunstâncias, e o será menos prevalente, quando só se demonstrem certos hábitos criminosos em geral”. Entretanto, a autora obtempera ser a denominada capacidade moral para delinqüir "condição necessária, mas não suficiente de culpabilidade: ela fornece ora uma simples possibilidade, ora uma probabilidade, mas insuficiente, por si só, para basear uma condenação. Esse indício assume forte importância sob a forma negativa, porque pode infirmar a conclusão a que se poderia chegar relativamente à culpa, razão pela qual é necessário ter cuidado na sua análise."

${ }^{88}$ VEIGA, Catarina, op. cit., p. 61. A idéia da autora não poderá ser transferida automaticamente para o Brasil, exceto naquilo que se relaciona com o julgamento feito pelo Tribunal do Júri em que os jurados decidem questões relativas à responsabilidade penal do réu sem exteriorizar os motivos dos seus votos.

${ }^{89}$ COSTA, António Manuel de Almeida, op. cit., p. 246. 
indiscutível que ele se aproxima daqueles (reincidência e antecedentes), bem como dos efeitos específicos da condenação e, por essa razão, também deve seguir aos princípios fixados para tais institutos no interior do sistema jurídico dentro do qual foi criado. ${ }^{90}$

As idéias de equilíbrio e da busca de um ponto intermediário para atender as necessidades da defesa e da reinserção do condenado no convívio social devem ser "lugar comum" para qualquer sistema jurídico que pretenda regular o registro criminal. Amparado nas orientações gerais da política criminal, é preciso descobrir em que ponto o registro criminal está inserido no sistema de justiça penal de qualquer país e conhecer qual é a sua natureza jurídica. ${ }^{91}$

A doutrina nacional não demonstrou grande interesse pelo assunto registro criminal, razão pela qual é necessário buscar na doutrina portuguesa duas posições conhecidas para iniciar o debate acerca da natureza jurídica do registro criminal.

A primeira delas está assentada na idéia de que a inscrição da condenação no registro criminal tem a natureza de sanção, pois dessa anotação é dado conhecimento aos particulares e à administração em geral, expondo a condenação que gerou a anotação. Sob esse ângulo é necessário saber se o lançamento ou inscrição seria fruto de pena (acessória) ou de medida de segurança, ${ }^{92}$ porquanto se decorre da primeira se subordinaria ao princípio da culpa, podendo, ainda, subordinar-se aos princípios da necessidade, da proporcionalidade e da menor intervenção social. Encarar o instituto como pena ou medida de segurança é posição falha, porque não privilegia a possibilidade de acesso para fins judiciais e de investigação científica, além de estar desconectada da base penal brasileira que não prevê a inscrição de condenação no registro como sanção penal. O registro criminal, portanto, não deve ser classificado como pena, efeitos da pena ou medida de segurança.

A doutrina portuguesa referida sugere outra forma para encarar o registro criminal,

90 O Código Penal brasileiro trata da chamada "prescrição" da reincidência. O artigo 64, inciso I, da lei penal dispõe que para efeito de reincidência não prevalece a condenação anterior se decorrido período de tempo superior a 5 (cinco) anos entre a data do cumprimento ou extinção da pena e a infração posterior, computados nesse lapso temporal o período de prova da suspensão ou do livramento condicional, se não revogados. Desse modo, caberia discutir o sigilo desses dados mediante sua colocação em campo do registro com acesso restrito e até o seu apagamento, ultrapassado lapso temporal fixado por lei.

${ }_{91}$ COSTA, António Manuel de Almeida, op. cit., p. 246, segunda parte, e 247-249.

${ }^{92}$ Francisco Bissoli Filho (op. cit., p. 23-24) ressalta que "tendo o Direito Positivo Penal brasileiro adotado o sistema vicariante ou unitário, admitindo a imposição de medidas de segurança, apenas aos inimputáveis e semi-imputáveis e de forma não cumulativa, há que se concluir que o conceito de periculosidade resultou restrito aos criminosos inimputáveis e semi-imputáveis, não podendo os imputáveis ser considerados perigosos. Assim, o critério da periculosidade como decorrência dos antecedentes e da reincidência criminal, em relação aos imputáveis, também não faz mais sentido, pena de se malferir, também, o princípio da legalidade." 
ainda sob o aspecto da sua natureza jurídica. Consiste em considerar que ele serve como instrumento para sustentar certos institutos, tratando-se de mero expediente técnico, sem autonomia material. Sob essa ótica, o registro criminal ficaria totalmente à mercê dos institutos aos quais serve como instrumento, inclusive, permaneceria regulado pelas normas que os regem. Embora possa ser admitido nessa concepção, para atender os fins da investigação científica e comprovação de interdições legais e judiciais, esta forma de ver o registro criminal não admitiria que os cadastros fossem acessados para fins particulares e administrativos. ${ }^{93}$

Essas posições, entretanto, não são completamente aceitáveis para facilitar o encontro da idéia da natureza jurídica do registro criminal. Elas decorrem de pontos de vista unilaterais, principalmente ao se constatar que a existência do registro de antecedentes criminais não tem expressão político-criminal nem qualquer efeito, caso os dados nele compilados não sejam acessados ou divulgados, mas contém indicações que permitem formular reflexões.

O registro criminal ganha relevo no momento da utilização das informações nele reunidas, tanto que a real aferição de sua natureza se liga à questão do acesso do seu conteúdo. Para tratar desse tema novamente se socorrerá das lições de António Manuel de Almeida Costa que fixou três grandes áreas ou pontos de visão sob os quais o registro criminal pode ser analisado.

Consoante o primeiro, o registro criminal serve aos juízes e aos membros do Ministério Público como verdadeiro "meio de prova" para instrução dos processos, com a finalidade de demonstrar a existência anterior de condenação, permitir imposição da pena adequada e forjar a reincidência. Como conseqüência desse ponto de visão toda a regulação do registro criminal, inclusive os casos de cancelamento, estariam subordinadas às normas processuais penais, podendo considerar-se determinados modelos de reabilitação como uma "proibição de prova", efeito não alcançado no sistema brasileiro atual, porque a condenação mesmo reabilitada é conhecida pelo juiz criminal, conforme preconiza o artigo 748, parte final, do Código de Processo Penal. O segundo modo de enxergar o registro criminal outorgar-lhe-ia a natureza instrumental, isto é, permitiria que ele funcionasse como indicador de possíveis incapacidades ou interdições profissionais resultantes de sentença penal condenatória, além de alimentar pesquisas estatísticas ou investigações científicas. Por derradeiro, é possível destinar o registro criminal à satisfação de fins particulares e

${ }^{93}$ COSTA, António Manuel de Almeida, op. cit., p. 248-249. 
administrativos, situação que ampliaria a estigmatização social do condenado e dificultaria sua reinserção social. ${ }^{94}$

O autor prossegue suas idéias e afirma que o registro criminal deve servir somente como instrumento coadjuvante da prevenção geral negativa, ou seja, satisfazer exigências no âmbito da defesa da sociedade e cumprir a finalidade de protegê-la contra o risco de reiterações criminosas das pessoas já condenadas, resultado da constatação das elevadas taxas de reincidência. Portanto, decorrendo o acesso aos cadastros para fins administrativos ou particulares da precaução contra a periculosidade dos condenados, António Manuel de Almeida Costa prega que o instituto deveria subordinar-se aos mesmos princípios que regem as medidas de segurança, tratando-se de providência de caráter penal destinada à prevenção da criminalidade. Ao final, o autor sintetiza sua posição apontando que de acordo com a função desempenhada e a partir das informações que dele se pretenda extrair o registro criminal poderá apresentar natureza mista ou complexa, ao assumir o caráter de "meio de prova", "instrumento subsidiário de outras figuras" ou de "medida de segurança", existindo em cada um desses níveis três institutos independentes, regidos de modo diverso e pertencentes a ramos jurídicos diferentes. ${ }^{95}$

Neste estudo, analisadas as posições doutrinárias acima indicadas e diante da proteção à privacidade e do sigilo dos dados pessoais que a Constituição Federal brasileira outorga ao cidadão, é possível considerar que para fins processuais penais o registro criminal assume a natureza jurídica de meio de prova da reincidência e dos antecedentes criminais.

Além disso, os dados extraídos do registro prestam-se à prevenção das reiterações criminosas e servem como meio de investigação orientando decisões para adoção das medidas judiciais e policiais, pois é afirmado que "o delinqüente pode tornar a infringir bens jurídico-criminais". 96

O efeito que resulta na estigmatização do condenado a partir da inscrição do seu nome no registro surge da inserção da própria condenação no registro criminal e da sua publicidade, ${ }^{97}$ mas ele não está ligado à natureza ou ao objetivo do sistema, embora aceito

${ }_{95}^{94}$ COSTA, António Manuel de Almeida, op. cit., p. 249-250.

95 Id., ibid., p. 250.

${ }^{96}$ Id., ibid., p. 349.

97 A estigmatização, forma preconceituosa de tratar o condenado e, por vezes, também, quem foi processado, normalmente é produto da opinião de terceiro sobre determinada pessoa, mas pode ser encontrada na avaliação da própria pessoa ao reviver com humor o fato de ter sido processada e conseguido livrar-se da decisão condenatória monocrática depois da interposição de recursos. Essa análise decorre da leitura de entrevista concedida ao Repórter Pedro Venceslau pelo Jornalista Ruy Castro (Revista Imprensa, Imprensa 
como conseqüência inevitável ${ }^{98}$ e seja consensual que devem ser buscados meios para máxima redução desse efeito.

O acesso ao registro criminal para fins particulares e administrativos não pode ser encarado como pena ou efeito da pena, pois se assim fosse teria a natureza de pena infamante e, portanto, não estaria de acordo com a tendência da política criminal, destoaria dos reflexos extraídos do texto constitucional brasileiro, ${ }^{99}$ e da orientação legislativa nacional, ${ }^{100}$ bem como caminharia no contrafluxo da tendência de restrição da publicidade dos cadastros criminais.

\subsection{Conteúdo, centralização e principais características do registro criminal}

Inicialmente, importa destacar que fatos sem dignidade penal não deveriam integrar o conteúdo do registro criminal, por exemplo, civil, administrativo ou disciplinar, cabendo informar nos pedidos de natureza criminal somente os fatos que tenham referido status a fim de impedir que as informações de natureza diversa possam causar interferências nos rumos do processo criminal. ${ }^{101}$

Ainda em relação ao conteúdo do registro criminal, foi assinalado ser tarefa difícil analisar o registro criminal na Espanha diante da diversidade de informações nele reunidas.

Editorial, São Paulo, ano 20, n. 226, p. 19, ago. 2007), especialmente no trecho a seguir transcrito: "Em 1982, quando era editor da Revista Status, enfrentou sua primeira batalha na Justiça. Foi processado por Roberto Carlos em função de um perfil que desagradou o cantor. Perdeu a batalha, foi condenado, mas não chegou a ser preso. Seus advogados recorreram e o autor recuperou o status de 'réu primário'. 'Como não cometi mais crimes, pude voltar a andar na rua com a cabeça erguida', diverte-se."

${ }^{98}$ COSTA, António Manuel de Almeida, op. cit., p. 251.

99 A impossibilidade de aplicar pena infamante não é tratada, expressamente, pela Constituição Federal ou pelo Código Penal brasileiro, mas sua vedação pode ser extraída do rol de proibições relativas às penas reguladas pelas alíneas do inciso XLVII do artigo $5^{\circ}$ da Constituição Federal.

${ }^{100}$ Apesar de a lei não definir quais seriam os crimes infamantes, quem cometer crime assim considerado poderá sofrer sanções de natureza profissional ou relativa aos atos da vida civil. Observa-se que é vedado o exercício da profíssão de representante comercial autônomo, nos termos da alínea "c" do artigo $4^{\circ}$ da Lei $n^{\circ}$ 4.886, de 1965, ao sujeito condenado por infração penal de natureza infamante, tais como falsidade, estelionato, apropriação indébita, contrabando, roubo, furto, lenocínio ou crimes também punidos com a perda de cargo público. A alínea "d" do artigo 35 da mesma lei indica como motivo justo, entre outros, para o representado rescindir contrato de representação comercial a condenação definitiva por crime considerado infamante. O artigo 8 ${ }^{\circ}$, da Lei $n^{\circ}$ 8.906, de 1994 (Estatuto da Advocacia), ao exigir idoneidade moral para inscrição como advogado, aponta que não atende o mencionado requisito quem tiver sido condenado por crime infamante, salvo reabilitação judicial. O inciso XXVIII do artigo 35 dessa lei também enumera como infração disciplinar a prática de crime infamante. Além disso, o inciso V do artigo 1.573 da Lei $n^{\circ} 10.406$, de 2002 (Novo Código Civil), estabelece que pode ser motivo caracterizador da impossibilidade da comunhão de vida a condenação por crime infamante. Em reforço à idéia, verifica-se que o artigo 57, da Lei $\mathrm{n}^{\circ} 6.001$, de 1973 (Estatuto do Índio), determina que "será tolerada a aplicação, pelos grupos tribais, de acordo com as instituições próprias, de sanções penais ou disciplinares contra os seus membros, desde que não revistam caráter cruel ou infamante, proibida em qualquer caso a pena de morte."

${ }^{101}$ COSTA, António Manuel de Almeida, op. cit., p. 253-254. 
Nesse país, além de compilar os antecedentes penais informados pelos tribunais ao Registro Central de Procesados y Penados, nos termos do artigo 225 da LECrim espanhola, o registro abarca delitos previstos no Código de Justiça Militar, da Marinha Mercante e Navegação Aérea e, em certo período, também abrangia os antecedentes relativos à perigosidade social e reunia antecedentes policiais. Portanto, criticou-se a abrangência do conteúdo do registro espanhol, cuja análise exige interpretar diversos textos legais relacionados a assuntos específicos, em relação à opção legislativa adotada na extinta Alemanha Federal, em meados de 1971, quando editada normatização única do tema. ${ }^{102}$

Atualmente, na Espanha, o registro reúne as inscrições das notas autorizadas pelas autoridades judiciais nas seguintes situações:

a) processados revéis;

b) condenados por delitos previstos no Código Penal;

c) condenados por delitos previstos em leis penais especiais, como Código Penal Militar e leis penais da Marinha Mercante e Navegação Aérea;

d) condenados beneficiados pela suspensão condicional da condenação;

e) pessoas submetidas a medidas de segurança de natureza penal. ${ }^{103}$

No Brasil, o conteúdo do registro criminal também é variado, porque em linhas gerais, além das anotações relativas aos processos criminais, nele são compiladas as seguintes informações:

a) identificação criminal produto do indiciamento em inquérito policial;

b) medidas despenalizadoras tratadas pela Lei ${ }^{\circ}$ 9.099, de 1995;

c) processos criminais suspensos na forma do artigo 366 do Código de Processo Penal, conforme disposto pela Lei $n^{\circ} 9.271$, de 1996, recentemente alterada pela Lei $\mathrm{n}^{\mathrm{o}} 11.719$, de 20 de junho de 2008, que entrou em vigor 60 (sessenta) dias após a data de sua publicação;

d) mandados de prisão expedidos e outras informações relativas ao cumprimento de pena.

\footnotetext{
${ }^{102}$ GROSSO GALVAN, Manuel, op. cit., p. 21-22.

103 Ao indicar que "procesados declarados en rebeldía" integram o registro español, Francisco Bueno Arús (op. cit., p. 31-32) ressalta "la posibilidad de incluir a todos los procesados, rebeldes o no, aún no ha dado lugar a un intento serio, por lo desproporcionado del esfuerzo con los escasos resultados que se obtendrían y porque las limitaciones a los derechos constitucionales deben ser mínimas.”
} 
A centralização do registro, por sua vez, é adotada pela legislação de diversos países. Isso permite existir um único cadastro em detrimento à idéia do regional, apregoada por Bonneville de Marsangy mediante a formação dos ficheiros locais baseados na naturalidade ou no domicílio do condenado para evitar a perda total do acervo, em casos de acidentes, como aquele incêndio ocorrido na Prefeitura de Paris, em 1871. ${ }^{104}$

Ao se criar, na França, os casiers judiciaires, forte era a idéia do efeito infamante do registro criminal sob a ótica preventiva geral e, portanto, adotava-se a idéia dos ficheiros regionais para permitir maior publicidade dos antecedentes dos ex-condenados. Atualmente, porém, é buscado o uso equilibrado das informações inseridas no registro criminal para permitir ao condenado condições, embora reduzidas, para sua ressocialização. Por isso é sentida uma tendência inversa, ou seja, da centralização dos cadastros em um serviço nacional único, detentor de competência para emissão dos certificados nos quais os riscos de fraude quanto ao acesso dos dados dos cadastros seriam menores, afastados os riscos de sua destruição por quaisquer incidentes, porque, atualmente, há ferramentas na área da informática que permitem a manutenção de cópias de segurança desses dados. ${ }^{105}$

No Brasil, o registro criminal é mantido pela União, pelos Estados-Membros e pelo Distrito Federal. Os dados criminais produzidos ou tratados pelos Tribunais Regionais Federais, Juízes Federais, Tribunais e Juízes dos Estados e do Distrito Federal são armazenados nos respectivos Institutos de Identificação e Estatística ou repartições congêneres, em razão do modelo federativo adotado no País desde 1889, mantido pela Constituição Federal de $1988 .{ }^{106}$ Inexiste, portanto, órgão central nacional com atribuição legal para reunir os dados criminais.

Seguindo na análise, cabe considerar que as características mais evidentes do sistema de registro criminal relativas à organização, funcionamento e acesso são autonomia e automatismo.

Autonomia para o registro significar existência independente de outros institutos, não funcionar como apêndice deles e seguir regras próprias.

O automatismo, característica que decorre da inscrição da informação independentemente de determinação judicial, contrapõe-se à idéia de o registro somente ser alimentado depois de existir decisão autônoma proferida pelo próprio juiz da

\footnotetext{
${ }^{104}$ COSTA, António Manuel de Almeida, op. cit., p. 160-161.

${ }^{105}$ Id., ibid., p. 253-254.

${ }^{106}$ SILVA, José Afonso. Curso de direito constitucional positivo. 9. ed. São Paulo: Malheiros, 1994. p. 91.
} 
condenação. $^{107}$

Em Portugal, a inscrição das decisões no registro é automática. Algumas anotações, em razão da diminuta gravidade ou pelo interesse na reintegração social da pessoa, podem não constar das certidões expedidas para fins determinados, procedendo-se desse modo à determinação judicial. Mesmo nessas hipóteses, a regra do automatismo é preservada, porque se limita a divulgação dos antecedentes e não sua inscrição no registro. ${ }^{108}$

No Brasil, a inscrição do nome do acusado no registro criminal é efeito automático da condenação não previsto na lei e declarado sem exigência de motivação do juiz na sentença. Isso é resultado da própria decisão condenatória e aplicação da fórmula genérica do registro do decisum resumido no jargão "publique-se, registre-se, intime-se e comunique-se", abreviada em muitas decisões pelas iniciais das palavras que iniciam a oração: PRIC.

A comunicação da decisão, determinada pelo juiz, é feita mediante encaminhamento do "boletim individual" ao Serviço de Identificação e Estatística. ${ }^{109}$

Além dessas características, cabe ressaltar que o registro criminal é cadastro acessível às pessoas autorizadas a operá-lo, por seu caráter restrito. As informações dele obtidas devem ser empregadas com reserva e dentro da finalidade específica para a qual foi solicitada, especialmente porque o nome e outros dados individualizadores da pessoa, normalmente, estão estampados no documento que contém essas informações. Acessado o registro para fins científicos ou estatísticos, por exemplo, sem referir os dados das pessoas cadastradas, as informações obtidas dele não serão sigilosas. ${ }^{110}$

Apesar de não constituir característica propriamente dita, é importante ressaltar que os servidores que cuidam do registro criminal devem ser capazes de responder o volume de requerimentos que lhe são incessantemente dirigidos, oriundos principalmente dos juízes e tribunais que solicitam a folha de antecedentes penais ao iniciar processo contra determinada pessoa, sem falar nos pedidos feitos pelos órgãos públicos e particulares.

Em síntese, neste ponto do estudo se mostra conveniente ressaltar que o registro deverá compilar dados criminais e buscar a centralização deles, observadas as peculiaridades e limites estatais, visando evitar a estigmatização da pessoa e, ao mesmo

\footnotetext{
${ }^{107}$ A inscrição mediante decisão judicial é empregada na Turquia (COSTA, António Manuel de Almeida, op. cit., p. 160-161).

${ }^{108}$ Id., ibid., p. 164.

${ }^{109}$ O parágrafo $3^{\circ}$ do artigo 809 do Código de Processo Penal trata do "boletim individual".

${ }^{110}$ Ver artigo $8^{\circ}$, número 2, Lei 57/98, de 18 de Agosto (VEIGA, Catarina, op. cit., p. 149).
} 
tempo, não reduzir a sensação de segurança social. Por fim, o registro criminal deve seguir as características básicas do instituto, como a autonomia e automatismo.

\subsection{Política criminal e registro criminal}

$\mathrm{O}$ estudo do registro criminal é tarefa que exige olhar o tema além do aspecto técnico-jurídico, pois é inegável sua proximidade com a política criminal e a influência que ela exerce sobre o modelo de registro adotado em cada país. ${ }^{111}$

Além disso, são as linhas político-criminais adotadas que permitem à sociedade compreender a finalidade desempenhada pelo registro. ${ }^{112}$

Portanto, a política criminal, considerada como "conjunto de princípios e recomendações para a reforma ou transformação da legislação criminal e dos órgãos encarregados de sua aplicação" 113 e, de modo mais emocional, como "conjunto sistemático de princípios e regras através dos quais o Estado promove a luta de prevenção e repressão das infrações penais", ${ }^{114}$ deve orientar as propostas para estruturação do registro criminal.

Ainda em relação à política criminal, Antonio Luis Chaves Camargo aponta que ela foi estudada inicialmente por von Liszt e, atualmente, ostenta caráter científico e ordena, sistematicamente, estratégias, táticas e meios sociais para controlar o crime. Segundo o autor, a política criminal orienta-se pelos princípios constitucionais, e assim o Estado fica impedido de interferir de modo arbitrário, "permitindo equilíbrio entre esta atuação e a liberdade das pessoas". ${ }^{115}$

A amplitude ou a restrição do conteúdo que compõe o registro, ao lado da facilidade ou do rigor para o acesso aos dados nele contidos, estão intimamente ligadas à prevalência do emprego do cadastro para reforçar as idéias de defesa social em face dos criminosos ou vinculados à busca da ressocialização e de redução dos efeitos estigmatizantes causados às

\footnotetext{
${ }^{111}$ GROSSO GALVAN, Manuel, op. cit., p. 1.

${ }^{112}$ VEIGA, Catarina, op. cit., p. 59.

${ }^{113}$ BATISTA, Nilo. Introdução crítica ao direito penal brasileiro. 8. ed. Rio de Janeiro: Revan, 2002. p. 34.

${ }^{114}$ René Ariel Dotti (Curso de direito penal: parte geral. Rio de Janeiro: Forense, 2005. p. 74) ainda afirma que, em sentido amplo, política criminal "compreende também os meios e os métodos aplicados na execução das penas e das medidas de segurança, visando o interesse social e a reinserção do infrator [...]. Em síntese, pode-se afirmar que a Política Criminal é a sabedoria legislativa do Estado na luta contra as infrações penais."

115 Sistemas de penas, dogmática jurídico-penal e política criminal. São Paulo: Cultural Paulista, 2002. p. 161-163.
} 
pessoas condenadas. $^{116}$

No jogo dos interesses entre a defesa social e a redução da estigmatização do condenado, que corresponde à idéia de eficiência e de garantismo, nota-se o papel a ser exercido pela política criminal em relação ao registro, especialmente no campo do acesso e do conteúdo.

O registro criminal já foi considerado como "instrumento de política criminal duvidoso e contestável, sobretudo do ponto de vista da ressocialização" do acusado. As informações do registro criminal não deveriam servir como indício de culpa e não poderiam causar entrave adicional à reinserção social do condenado, mas aproximar-se da função básica de orientar o juiz no momento da escolha da quantidade e do tipo de pena a aplicar. Os dados fornecidos pelo registro não deveriam servir como "meio de prova inculpatório" ou influenciadores da análise da responsabilidade penal do acusado pelo fato que lhe é atribuído. O registro deveria mostrar-se e ser visto sempre como instrumento útil para a prevenção geral e especial. $^{117}$

O registro criminal foi denominado como "ponta de um iceberg" que esconde a base do sistema de controle e repressão estatal, que atua praticamente em liberdade e sem limites estimulado pela (des)estrutura jurídica desse sistema. Os antecedentes criminais servem aos juízes e tribunais para o exercício sutil de tarefa que sequer é pensada, discutida e questionada, porque a partir da inscrição do nome da pessoa no registro e do acesso aos dados é possível o exercício de uma espécie de controle social permanente e generalizado em relação ao indivíduo, que é mais duradouro e, algumas vezes, tão efetivo quanto a própria condenação. ${ }^{118}$

Os antecedentes penais e o registro exercem papéis claros e definidos de controle social e de estigmatização do delinqüente, consistindo em impedimento sensível para a reinserção social dos condenados, embora seja tema freqüentemente distante das discussões relacionadas ao sistema criminal. Os antecedentes penais não nasceram ao acaso, mas com a finalidade de demonstrar que o cumprimento da pena resultado do crime praticado não extingue suas conseqüências, perpetuando a "relação poder-infrator". 119

O registro criminal não deve ser considerado como um "quartinho de despejo", "porão" ou "sótão" no qual são depositadas as informações relativas aos antecedentes

\footnotetext{
${ }^{116}$ COSTA, António Manuel de Almeida, op. cit., p. 193.

${ }^{117}$ VEIGA, Catarina, op. cit., p. 60.

${ }^{118}$ GROSSO GALVAN, Manuel, op. cit., p. 11.

${ }^{119}$ Id., ibid., p. 8 e 206.
} 
criminais das pessoas, porque ao contrário desses compartimentos domésticos, usualmente destinados para servir de depósito para guardar objetos pouco utilizados, ele reúne informações facilmente consultadas e aptas ao apontamento de fatos negativos do passado da pessoa e, minimamente, capazes de reduzir-lhe o conceito social.

Se, por um lado, "a persecução penal não começa apenas com o oferecimento da acusação (denúncia ou queixa-crime), mas tem início com os primeiros atos estatais investigativos", ${ }^{120}$ as conseqüências do crime para o condenado não se esgotam com o término do cumprimento da pena, pois se imagina que a condenação é insuficiente para pagar o débito por ele adquirido. ${ }^{121}$

Embora o registro criminal sirva como uma espécie de memória pública das anotações relativas ao envolvimento das pessoas com crimes, além de desempenhar papel de instrumento auxiliar para o controle estatal sobre essa parcela de pessoas, ${ }^{122}$ no Estado Democrático de Direito ele deve ser concebido e dotado de mecanismos não-impeditivos da construção de uma sociedade livre, justa e solidária, sem revestir-se unicamente do caráter discriminatório que lhe é indissociável. ${ }^{123}$

Com o intuito de não se afastar do caráter democrático do Estado brasileiro, o registro criminal deveria ser estruturado a partir de orientação político-criminal fundada nos princípios constitucionais aplicáveis ao processo penal, buscando, por exemplo, a criação de mecanismos que estabeleçam, além das portas de entrada, as vias de saída desse sistema no qual é comum que a anotação relativa ao antecedente criminal acompanhe a pessoa até o final da vida.

${ }^{120}$ MORAES, Maurício Zanoide. Perplexidade de Jano: quando o passado é mais presente do que o futuro (nova regulamentação do interrogatório e sua aplicabilidade na fase pré-processual). In: YARSHELL, Flávio Luiz; MORAES, Maurício Zanoide (Coord.). Estudos em homenagem à Professora Ada Pellegrini Grinover. São Paulo: DPJ, 2005. p. 375.

${ }^{121}$ Neste ponto cabe ressaltar o pensamento de Carnelutti relacionado à decisão judicial absolutória ou condenatória proferida em processo-crime. Para o autor, a primeira decisão, com trânsito em julgado, encerrava o processo mesmo que provas novas pudessem surgir e indicar que a pessoa absolvida era culpada. A segunda, ou seja, a decisão condenatória para ele não tinha idêntico significado, porque, mesmo sujeita à revisão, a condenação não significa a última palavra em um processo (p. 67). Mais adiante (p. 77), afirmou com precisão: "as pessoas crêem que o processo penal termina com a condenação e não é verdade; as pessoas crêem que a pena termina com a saída do cárcere, e não é verdade; as pessoas crêem que o cárcere perpétuo seja a única pena perpétua; e não é verdade. A pena, se não mesmo sempre, nove vezes em dez não termina nunca. Quem em pecado está é perdido. Cristo perdoa, mas os homens não" (FRANCESCO, Carnelutti. Misérias do processo penal. Trad. José Antonio Cardinalli. Campinas: Conan, 1995).

${ }_{122}$ GROSSO GALVAN, Manuel, op. cit., p. 126.

${ }^{123}$ Francisco Bissoli Filho (op. cit., p. 23-24) ressalta que "também o discurso dogmático trata com diferença o indivíduo que possui antecedentes ou é reincidente criminal, via de regra sendo-lhe desfavorável. Essa diferenciação, contida na legislação e no discurso dogmático, passa a ser um critério de seleção, na qual os indivíduos que detêm antecedentes ou são reincidentes criminais passam a ser mais facilmente selecionados do que outros pelas diversas agências do sistema penal. Essa diferenciação, por sua vez, produz a estigmatização do criminoso, pois, mesmo após cumprida a pena, perdura a marca por ter sido anteriormente condenado, processado ou investigado, resultando, muitas vezes, numa carreira criminal.” 


\subsection{Tecnologia e registro criminal}

Diversas formas de conhecimento humano são empregadas para compor o registro criminal, tais como o alfabeto que serve para ordenar os nomes das pessoas cadastradas, os algarismos arábicos que permitem numerar as fichas e os arquivos, além da datiloscopia que poderia ser usada também para classificar as fichas individuais a partir do critério fornecido pelas fórmulas datiloscópicas. Ademais, outras técnicas científicas modernas, como a informática, facilitam o acesso aos dados do registro criminal.

Francisco Muñoz Conde adverte que empregar a informática e a mecanização para controlar antecedentes criminais, embora seja eficaz, pode expor a intimidade, as idéias e os interesses do cidadão de forma não imaginada, tenha ele se envolvido ou não com crimes, convertendo-o em um simples número. ${ }^{124}$

Ao tratar da problemática da intimidade e do processo penal, Ada Pellegrini Grinover também considera que a vida moderna evolui sob pressão das relações sociais e do progresso dos meios técnicos, enfatizando ser necessário proteger o indivíduo dos ataques à privacidade facilitados pela tecnologia. ${ }^{125}$

As posições assumidas pelos autores referidos permitem entender que a privacidade limita o emprego da tecnologia sob pena de causar graves ofensas individuais. Esse limite, portanto, também deve estar presente ao se empregar a tecnologia no sistema do registro criminal.

$\mathrm{Na}$ Espanha, antes do emprego dos meios tecnológicos, foram usadas soluções simples para facilitar o acesso às informações criminais. Assim, desde 1910, permite-se a solicitação dos antecedentes penais pelo correio, prática instituída para facilitar a emissão das certidões aos cidadãos residentes fora de Madrid onde está sediado o Registro Central de Penados y Rebeldes, propiciando ao usuário pagar taxas justas pelo serviço, e à administração economizar por não atender o público na repartição. Nesse mesmo país, foi permitido aos juízes e tribunais, com competência para apurar atividades terroristas e afins, solicitar pelo telégrafo a emissão de informações do registro criminal, nos termos do artículo $5^{\circ}$ del Real Decreto Ley de Seguridad Ciudadana, de 26 de enero de $1979 .^{126}$

\footnotetext{
${ }^{124}$ GROSSO GALVAN, Manuel, op. cit., p. XII (Prólogo de Francisco Muñoz Conde).

${ }^{125}$ GRINOVER, Ada Pellegrini. Liberdades públicas e processo penal. 2. ed. São Paulo: RT, 1982. p. 70.

${ }^{126}$ GROSSO GALVAN, Manuel, op. cit., p. 174-179.
} 
É importante destacar, também, que o artigo 136, número 4, do Código Penal Espanhol, alterado em 1995, dispôs que as inscrições do registro não são públicas, permitindo supor que o acesso ao dados do Registro Central de Penados y Rebeldes seja restrito.

Ainda na Espanha, em meados de 1980, a tecnologia começou ser empregada no sistema de registro criminal, porque a partir dessa época foi possível a emissão das certidões solicitadas à distância a principiar de terminais instalados e operados por funcionários estranhos ao corpo de servidores do próprio sistema. Nesse período, existia preocupação com a oposição que determinados grupos de trabalhadores do próprio registro e de outras esferas da administração pública externavam à evolução do sistema. Ponderouse que fornecer informações coerentes aos servidores e assegurar-lhes os postos de trabalho, supostamente ameaçados pelo progresso, seriam formas de enfrentar essas resistências à modernidade. ${ }^{127}$

Ao lado da informática, a Internet ${ }^{128}$ também pode ser usada no gerenciamento dos sistemas de armazenamento de dados, como o registro criminal, pois poderá servir como ferramenta para vários usos entre eles universalizar-lhe o acesso. A proteção aos dados pessoais e a rede mundial de computadores são questões que poderão relacionar-se ao registro criminal. ${ }^{129}$

Facilitar o acesso aos dados compilados no registro criminal mediante o emprego do correio e permitir ao juiz conhecer informações criminais utilizando o telégrafo foram providências adotadas na Espanha em épocas distintas do Século XX, cuja adoção deve ser destacada, não pela modernidade daqueles meios de comunicação, pois atualmente correio e telégrafo podem ser substituídos por outras vias mais velozes de transmissão de informações, mas para pensar ser o registro criminal instituto que deve funcionar conectado à modernidade $\mathrm{e}$ ao avanço tecnológico sob pena de mostrar-se obsoleto.

A tecnologia aplicada ao registro criminal, que em determinada época foi representada pela mecanização e depois pela informatização, é importante para dotar o sistema de eficiência. É preciso estimular os responsáveis pelo gerenciamento do registro criminal conhecerem novos métodos e acompanharem as evoluções científicas aplicáveis

\footnotetext{
${ }^{127}$ GROSSO GALVAN, Manuel, op. cit., p. 183-185.

128 CASTRO, Catarina Sarmento e. Protecção de dados pessoais na Internet. Sub judice - Justiça e Sociedade, Coimbra: Almedina, n. 35, p. 11, set. 2006.

${ }^{129}$ Em São Paulo, a Secretaria da Segurança Pública fornece atestado de antecedentes criminais, por meio da Internet, mediante o preenchimento dos dados pessoais, número e data de expedição do documento de identidade emitido no próprio Estado (SECRETARIA DA SEGURANÇA PÚBLICA. Disponível em: $<$ http://www2.ssp.sp.gov.br/atestado/Atestado02.cfm>. Acesso em: 28 dez. 2007).
} 
ao sistema, bem como investirem treinando pessoal e adquirindo ferramentas que comprovadamente tornem o registro criminal mais eficiente e seguro. 


\section{ORIGENS E DIREITO COMPARADO}

\subsection{Origens do registro criminal}

O estudo das origens remotas do registro criminal leva ao período medieval, quando o instituto sequer havia sido concebido de modo autônomo, mas a apuração do fato e a execução da pena geravam infâmia e estigmatização em relação ao condenado.

Seguindo a linha do tempo e acompanhando a evolução jurídico-social, é possível notar a amenização da crueldade das penas e a substituição dos castigos físicos pela pena de prisão. Ao mesmo tempo, a necessidade de apontar a reincidência e a existência de interdições decorrentes de sentenças judiciais são condições propícias ao florescimento da idéia da compilação dos dados criminais das pessoas condenadas em cadastros.

O registro criminal apareceu, efetivamente, durante a Revolução Francesa e posteriormente se implantou em diversos países da Europa, coincidindo com o triunfo das burguesias. Seu surgimento não decorreu de causalidade, porém foi resultado de indiscutível ação estatal que verificou a utilidade de criar e manter uma espécie de memória dos criminosos. ${ }^{130}$

Somente na segunda metade do século XIX, na França, é possível encontrar a origem próxima do registro criminal, instituído nos moldes semelhantes aos atuais, embora nesse período fosse reduzida a preocupação com a publicidade das informações nele compiladas, característica depois alterada.

A análise da origem remota e próxima do registro criminal a seguir apresentada, a descrição do ambiente no qual ele se estabeleceu e a exposição das razões que motivaram sua criação permitirão melhor compreender seu desenvolvimento ao longo do tempo e o perfil e estágio atuais do instituto, bem como fornecerão, ainda, subsídios úteis para sustentar e expor as razões de algumas propostas para a estruturação do registro criminal no Brasil, apresentadas no encerramento deste estudo.

${ }^{130}$ GROSSO GALVAN, Manuel, op. cit., p. 126. 


\subsection{Origem remota}

O registro criminal surgiu na França em 1850 mediante a adoção do sistema de Bonneville de Marsangy. É um instituto cuja sistematização é relativamente recente, em razão de não ser antiga a idéia de concentrarem-se os antecedentes pessoais em arquivos, bem como de ser também moderna a ênfase dada à avaliação dos antecedentes dos autores de crimes. Cabe ressaltar que o instituto exercia, à época em que foi criado, o papel de moralização social ao mesmo tempo que funcionava como inibidor das práticas criminosas. $^{131}$

Essas finalidades do registro, aliás, são mantidas de modo simulado até os dias de hoje, pois a inserção do nome da pessoa no registro criminal "gera a presunção de a pessoa ser de comportamento duvidoso" e no caso daquele que foi absolvido evidencia "não haver demonstrado a inocência". ${ }^{132}$

O instituto deveria cumprir, de acordo com o seu criador, três funções principais. Em primeiro lugar serviria como instrumento auxiliar para reprimir delitos, por exemplo, contribuindo como parâmetro para a imposição da pena mediante a aferição da personalidade do delinqüente ou caracterização da reincidência. Em segundo, seria utilizado para manter afastada das listas eleitorais e de jurados a pessoa condenada ${ }^{133}$ e, por último, exerceria o efeito moralizador por meio da estigmatização daqueles que tivessem os nomes anotados nos registros em razão de condenação de natureza criminal. ${ }^{134}$

O registro criminal, à época do seu aparecimento na França, apresentava duas vertentes principais. Por uma delas era visto como um centro de documentação no qual permaneceriam armazenados os antecedentes criminais das pessoas servindo como instrumento para caracterizar a reincidência e controlar as interdições impostas pela Justiça. Pela outra vertente o registro era considerado como verdadeira punição autônoma, pois tornava pública a condenação criminal e exacerbava a função estigmatizante da pena. ${ }^{135}$

Nota-se, portanto, que a função instrumental e o efeito estigmatizante eram as

\footnotetext{
${ }^{131}$ COSTA, António Manuel de Almeida, op. cit., p. 3 e 9.

${ }^{132}$ Os trechos colocados entre aspas foram extraídos da ementa do acórdão proferido no Recurso Ordinário em Mandado de Segurança $n^{\circ}$ 6.761/SP (BRASIL. Superior Tribunal de Justiça..., cit.).

${ }^{133} \mathrm{O}$ artigo 436 do Código de Processo Penal, alterado pela Lei $\mathrm{n}^{\circ} 11.689$, de 9 de junho de 2008, dispõe que os jurados serão escolhidos entre cidadãos maiores de 18 (dezoito) anos de notória idoneidade. A respeito da falta de idoneidade moral do jurado incurso em ação penal ou sob gozo de sursis e seus efeitos, cf. FRANCO, Alberto Silva et al. Teoria e prática do júri. 6. ed. São Paulo: RT, 1997. p. 126-127.

${ }^{134}$ COSTA, António Manuel de Almeida, op. cit.,p. 6, nota de rodapé 3.

${ }^{135}$ Id., ibid., p. 12.
} 
finalidades básicas do registro quando de sua concepção.

Conquanto seja possível fixar na metade do século XIX o marco temporal indicador da origem próxima do registro criminal, conhecer sua procedência remota exige retornar muito mais na linha do tempo.

Desde a Idade Média até os tempos modernos, período em que o registro criminal surgiu e passou a interessar aos estudiosos das finalidades da pena, a retribuição e a utilidade decorrentes da punição penal serviam para aplacar a ira divina e também para impedir que novas represálias sobrenaturais atingissem o criminoso ou a coletividade. ${ }^{136}$ Em razão do afastamento entre os conceitos de crime e de pecado, a pena e o registro criminal não mais ostentam caráter sacro, embora conhecer esse traço permita discutir as iniciativas na área criminal que surjam além das questões técnicas e científicas.

No período medieval, em relação ao qual se fez uma breve alusão, a vingança era um instrumento de defesa colocado nas mãos do homem comum, muitas vezes abandonado à sua própria sorte, em virtude da ausência, quase total, das leis. Nessa época, aliás, considerou-se que renunciar ao emprego da vingança equivaleria ao suicídio e que o ofensor, no caso da prática de infrações mais graves, era tido como um inimigo. ${ }^{137}$

Essa anomia vivenciada na fase medieval, felizmente, não é mais a regra da sociedade moderna. Nos tempos atuais, o Estado por intermédio das suas instituições procura ocupar o espaço que the foi conferido, enfrentando as dificuldades e os problemas causados pelo afastamento do poder público nas áreas próximas ou distantes dos centros urbanos. Preencher esses espaços pode ser tarefa árdua, como é atualmente o controle da criminalidade violenta e organizada no Brasil.

As constatações extraídas da análise sintética do período embrionário do registro criminal servem como base ao menos para duas reflexões.

Em primeiro lugar, cabe afirmar que restringir e controlar o acesso aos dados do registro criminal não deve ser encarado como uma espécie de renúncia do Poder Público ao direito de conhecer os antecedentes criminais das pessoas submetidas à ação da Justiça. A partir desse ponto, cumpre frisar que este estudo não pretende mostrar a inviabilidade do registro criminal, mas, ao contrário, analisá-lo e discutir idéias que permitam estruturá-lo de modo a cumprir fielmente o seu papel sem prejudicar a privacidade e a liberdade das pessoas.

\footnotetext{
${ }^{136}$ COSTA, António Manuel de Almeida, op. cit., p. 21-22.

${ }^{137}$ Id., ibid., p. 25-26.
} 
Em segundo, não é possível considerar o infrator da lei penal, cujos dados qualificativos foram inseridos no sistema do registro criminal algumas vezes antes do seu julgamento e condenação, como um "inimigo público" e, em razão disso, prolongar, indefinidamente, a manutenção e exposição desse registro, sujeitando-o, perenemente, à divulgação desses dados. Fixar lapso temporal para o acesso às informações incluídas no registro é providência importante cuja análise e discussão será apresentada neste trabalho.

$\mathrm{Na}$ Europa, desde a Idade Média até antes do Iluminismo, o sistema penal esteve organizado de modo a não necessitar do desenvolvimento do registro criminal, pois a retribuição e a prevenção geral que decorriam da pena imposta eram percebidas pela mera aplicação da sanção. O arbítrio concedido ao juiz para determinar a pena e a crueldade na aplicação da sanção, acrescido da publicidade decorrente da intervenção dos órgãos repressivos, fazia que a notícia do castigo fosse conhecida em todo o território. A redução do arbítrio judicial, da crueldade das sanções e da publicidade das decisões judiciais, efeitos alcançados para atender tendência político-criminal particularmente presente no período iluminista, sedimentaram bases adequadas para o desenvolvimento do moderno registro criminal, apesar da precariedade de meios técnicos e materiais que proporcionavam a publicidade necessária às decisões da justiça penal. ${ }^{138}$

Semelhante ao instituto da pena introduzido nas civilizações modernas para substituir a vingança, geralmente desproporcional à ofensa, o desenvolvimento do registro criminal, mesmo nas suas fases embrionárias, também foi resultado da evolução social, porque substituiu a estigmatização, resultado da crueldade e da publicidade próprias da aplicação da pena, pela inclusão do nome do condenado em cadastros que realizavam essa missão.

Retornando ao período medieval, é necessário considerar que, em consonância com a dinâmica social da época, utilizaram-se o estigma e a infâmia como instrumentos para o controle social. A imagem das pessoas na sociedade, que era conhecida como publica fama, servia como garantia para o cumprimento de obrigações e assegurava o crédito dos testemunhos.

A infâmia que pode ser entendida como um juízo depreciativo feito em relação à personalidade da pessoa deve ser vista no contexto histórico como a origem do moderno registro criminal. Esse juízo pessoal, aliás, poderia decorrer de qualquer fato que 
acarretasse indignidade social $^{139}$ ou jurídica, bastando para tanto o nascimento sem definição da paternidade ou a proibição do exercício de qualquer cargo ou função em razão de determinação judicial. Sob essas duas vertentes a infâmia era classificada como infamia facti ou infamia iuris, ${ }^{140}$ mas, pela dificuldade de empregar-se a escrita, a palavra falada servia para provar aquilo que seria relevante ao mundo jurídico. À época medieval, ainda, a divulgação da condenação gerava estigma contra o acusado, à medida que poderia ser lembrada verbalmente e servir como prova de reincidência, tal qual fosse uma espécie de registro criminal assentado na memória das pessoas. ${ }^{141}$

A infâmia era resultado da publicidade ínsita no processo e na execução das penas aplicadas nos períodos medieval e moderno. A publicidade fazia parte da sanção, gerando efeito estigmatizante, ${ }^{142}$ e ao mesmo tempo cumpria papel instrumental, pois a divulgação da condenação permitia que, em caso de imposição de outra pena, a condenação precedente seria resgatada por intermédio da memória para a futura configuração de um antecedente criminal. Aliás, cabe frisar neste ponto que as mutilações e as marcas-de-ferro não devem ser consideradas precursoras exclusivas do registro criminal, porque nem todas as legislações antigas as previam e aquelas que o faziam não impunham sua aplicação à totalidade dos delitos cometidos nem permitiam fosse imposta a todas as pessoas. Assim, mesmo nos sistemas punitivos em que esses meios cruéis foram utilizados, eles não funcionavam como prova plena de antecedente criminal, porquanto o seu emprego poderia ser vedado para determinadas infrações e certas pessoas. ${ }^{143}$

No período medieval, entretanto, as diversas modalidades de mutilações, tais como o arrancamento dos dedos (das mãos ou dos pés), dos membros, dos olhos, das orelhas e da língua, além da castração, serviam como método cruel de punição e, observada a ressalva

\footnotetext{
${ }^{139} \mathrm{O}$ efeito negativo da divulgação de informações, mesmo não relacionadas à prática de crimes, é bem ilustrado na obra de Raul Pompéia (O Ateneu. 16 ed. São Paulo: Ática, 1996. p. 50-51). O autor mostrou que o "Livro das notas", considerado a mais terrível das instituições mantidas naquele estabelecimento de ensino, era o trágico repositório em que cada professor, mesmo aqueles que acabavam despedidos por defeitos como a prática de violência e de imoralidades, anotava as supostas indisciplinas dos alunos. Essas notas, lidas em público pelo diretor perante todos os alunos reunidos a cada manhã, tornavam irrevogável a difamação estampada.

${ }^{140}$ A infamia facti consistia em juízo de desvalor moral, feito pela coletividade em relação aos seus membros, baseado na personalidade da pessoa, enquanto a infamia iuris era a censura, feita pela ordem jurídica, que resultava na incapacidade para o exercício de certas funções (VEIGA, Catarina, op. cit., p. 55). (em especial, ver nota de rodapé 74).

${ }^{141}$ COSTA, António Manuel de Almeida, op. cit., p. 38-44.

${ }^{142}$ A publicidade dos atos processuais é garantia constitucional prevista no artigo $5^{\circ}$, inciso LX, da Constituição Federal. Antes de 1988, era tratada pelo artigo 792 do Código de Processo Penal. Seu objetivo é quebrar o sigilo de alguns julgamentos, propiciar transparência à atividade jurisdicional e permitir fiscalização das partes e da comunidade para evitar excessos ou arbitrariedades (FERNANDES, Antonio Scarance. Processo..., cit., p. 67-68).

${ }^{143}$ COSTA, António Manuel de Almeida, op. cit., p. 45-49.
} 
anteriormente feita, algumas vezes poderiam fazer o papel de registro criminal detalhado, porque em razão da modalidade da mutilação era possível reconhecer a existência de crime anterior e até supor sua natureza. Ressalva-se novamente que as mutilações, contudo, demonstravam de modo precário a prática de crime anterior, pois no antigo direito penal germânico cabia a imposição das penas pecuniárias às pessoas que integravam classes sociais privilegiadas ou estas poderiam livrar-se das sanções corporais pelo pagamento de multa. $^{144}$

Tal qual ocorreu com as mutilações, na Idade Média as marcas-de-ferro nem sempre eram aplicáveis à totalidade dos criminosos reincidentes, porque essa pena cruel também poderia ser evitada mediante o pagamento de multas. Todavia, nos casos em que a marca-de-ferro era aplicada como sanção corporal sua imposição gerava notoriedade ao delito e infâmia ao delinqüente, servindo como um arremedo de registro criminal, principalmente, em virtude da precariedade dos meios de controle dos antecedentes criminais naquele período da história.

A marca-de-ferrro, também conhecida como "marca penal", foi tida na fase medieval como um sistema válido para comprovar envolvimentos anteriores da pessoa com a lei, pois nesse momento da história da humanidade era impensável instituírem-se arquivos judiciais e formas de transmissão das informações neles reunidas, tanto que para conhecer a reincidência o método usado, embora extremamente cruel, era marcar diretamente o corpo dos criminosos. Apesar disso, ainda é preciso ressalvar que a marca corporal não foi amplamente aplicada, tanto que na Espanha a reincidência e reiteração criminosa praticamente não foram punidas por muito tempo, até que os "Alcades de Casa y Corte" publicaram um Auto, em 11 de setembro de 1609, no qual se estipulava que os ladrões não enviados às galés, por não ser importante o primeiro furto, deveriam ser marcados debaixo do braço ou nas espáduas, ou em parte do corpo mais conveniente, para que fossem conhecidos e se soubesse que foram castigados. A aplicação da marca corporal também foi prevista na Espanha para vagabundos e ociosos. Nesse período, a prática do terceiro crime resultava na aplicação de pena incomparavelmente mais grave que a aplicada pelo cometimento dos crimes anteriores, tanto que em 1744 foi proposta a substituição da pena de morte pela marcação do corpo do criminoso ao Rei Felipe V, na Espanha, para amenizar a dureza decorrente da imposição da pena de morte ao autor do terceiro furto. ${ }^{145}$

\footnotetext{
${ }^{144}$ COSTA, António Manuel de Almeida, op. cit., p. 51 e 56.

145 GROSSO GALVAN, Manuel, op. cit., p. 15-16. A propósito da referência feita aos "vagabundos e ociosos" deve ser assinalado que na Espanha existiu o Registro Central de Peligrosos Sociales, no qual eram
} 
Na Idade Média, portanto, a infamia facti, resultado da aplicação de sanções corporais cruéis que deformavam o corpo dos condenados, pode ser vista como o nascedouro do registro criminal, ${ }^{146}$ embora deva ser lembrado que a mutilação ou as marcas produzidas também serviram para comprovar a reincidência.

Seguindo a linha evolutiva do tempo, na Idade Moderna o direito criminal experimentou progresso lento, mas significativo. As penas cruéis foram amenizadas e, muitas vezes, substituídas pela prisão dos infratores, ao mesmo tempo que a escrita ocupava o lugar da forma oral, permitindo a criação de cadastros precários que serviram como fonte de inspiração para o moderno registro criminal. Embora as penas corporais, tais como as mutilações e as marcas-de-ferro fossem abandonadas na Europa por razões humanitárias entre o final do século XVIII até o século XIX, o processo de apuração do crime e a execução da pena ainda geravam efeito estigmatizante. Tal efeito era naturalmente sentido na localidade em que ocorria a apuração do crime e a imposição da pena, tanto que em Portugal, pelas regras das Ordenações Filipinas, era previsto que, na cidade ou vila na qual fosse instaurado o processo para a apuração do crime, o juiz local deveria correr a folha do réu, tratando-se, pois, do antecessor lusitano do registro criminal. $^{147}$

Na Idade Moderna, o controle social decorrente da infâmia gerada pela aplicação da pena já cumpria uma das finalidades do registro criminal, mas se mostrava ineficaz, pois, ao passo que as penas mutilantes entravam em desuso, havia dificuldade para demonstrar os antecedentes criminais do infrator. Nesse cenário, somado o aumento da mobilidade das pessoas e a redução da tortura, seja como meio de obter confissões ou forma de punição do infrator, permeado da necessidade de demonstrar a reincidência e as interdições decorrentes das sentenças, surgia um ambiente propício ao desenvolvimento das bases para a criação do moderno registro criminal. Assim, tanto na Idade Média quanto na Idade Moderna, conquanto não seja encontrado qualquer instituto exclusivamente identificado como precedente histórico do registro criminal, permeia a idéia de que a infamia facti, resultado do sistema punitivo que gerava a estigmatização ou infâmia do infrator, faz-se presente durante a criação e o desenvolvimento do registro criminal do modo como é

${ }^{146}$ COSTA, António Manuel de Almeida, op. cit., p. 58-63.

${ }^{147}$ Id., ibid., p. 74-80. 
modernamente. ${ }^{148}$

\subsection{Origem próxima}

Conforme já assinalado somente em 1850, na França, o registro criminal alcançou os contornos hoje conhecidos. Ele se desenvolveu com o objetivo de atender a necessidade de mostrar os antecedentes das pessoas para caracterizar a reincidência e dotar de eficácia as interdições decorrentes das condenações. O sistema se espalhou pelo mundo com o fim de atender a demanda dos tribunais e outros órgãos públicos acerca dos antecedentes criminais das pessoas, à exceção da Inglaterra e dos países do common law, nos quais o cadastro de condenações buscava somente criar uma estatística criminal. ${ }^{149}$ Em relação a esse ponto, interessa anotar que a Justiça brasileira ainda pouco utiliza a estatística judiciária para analisar aspectos relacionados à distribuição da justiça. ${ }^{150}$

Retornando um pouco na linha do tempo, na França, é possível alcançar a Prefeitura da Polícia de Paris, no início do século XVIII, que mantinha uma antiga coleção dos registros das condenações dos tribunais franceses. Esse acervo de antecedentes serviu à justiça criminal e reforçou a idéia que naquele momento da civilização humana cabia provar condenações criminais anteriores sem mutilar e ou marcar o corpo dos condenados. ${ }^{151}$

Outras formas embrionárias de registro criminal também existiram na França em meados do século XVIII, a saber, o registro de mendicância criado em 1724 no Hospital Geral de Paris e a centralização das anotações das condenações criminais também proferidas pela justiça em Paris a partir de 1790. Entretanto, eram cadastros pobres em conteúdo, abrangiam áreas geográficas reduzidas e estavam vinculados aos organismos que os mantinham, sem qualquer autonomia. ${ }^{152}$

As bases para a criação de um centro detentor de documentação autônomo e que atendesse a função jurisdicional em todo o país foram trazidas pelo artigo $29^{\circ}, \S 1^{\circ}$, da 19 vendémiaire do ano IV. Essa legislação obrigava os escrivães dos tribunais correicionais organizarem registros alfabéticos no quais eles inscreviam os nomes das pessoas chamadas

\footnotetext{
${ }^{148}$ COSTA, António Manuel de Almeida, op. cit., p. 83-85.

${ }^{149}$ Id., ibid., p. 86-87.

${ }^{150}$ ARAGÃO, E. D. Moniz. Estatística judiciária. Revista Forense, Rio de Janeiro: Forense, v. 365, p. 715 ,fev. 2003.

${ }^{151}$ COSTA, António Manuel de Almeida, op. cit., p. 89-90.

${ }^{152}$ Id., ibid., p. 90.
} 
ao tribunal correicional ou perante o júri. A inscrição dos nomes deveria ser acompanhada de uma referência sobre o caso e do andamento do processo, precisando remeter-se tais informações ao registro central cuja criação também foi prevista pela mesma lei. Referido sistema foi mantido, embora com algumas alterações, no Código de Instrução Criminal de 1808 (artigos $600^{\circ}$ e $602^{\circ}$ ), havendo nesta época a criação de registros centrais no Ministério da Justiça e na Polícia Geral de Paris que deveriam receber dos tribunais trimestralmente informações das condenações decretadas. ${ }^{153}$

O Registro Central Judicial, regulado pelo Código Napoleônico e instituído na França no início século XIX, irradiou-se sobre diversos países da Europa e foi considerado, à época, instrumento cuja criação era necessária, visão aparentemente inalterada do instituto até hoje, ${ }^{154}$ tanto que poucas são as vozes que se dispõem discutir os efeitos que determinadas anotações contidas no registro criminal causam às pessoas e propor alterações para corrigir distorções desse sistema.

Ainda que relativamente estruturado nessa época, o sistema de registro criminal não atendia, satisfatoriamente, as necessidades judiciárias. $\mathrm{O}$ acervo das fichas de cada um dos tribunais referia-se tão-somente aos casos nele julgados, impedindo a demonstração de eventual condenação em outra circunscrição, enquanto o modo de registrar as decisões, apesar de obedecer à ordem alfabética, exigia que todos os livros de registro fossem examinados para certificar-se se o nome da pessoa consultada constava do cadastro, tornando qualquer pesquisa demorada e sujeita a erros. ${ }^{155}$

$\mathrm{Na}$ França, a duplicidade de registros centrais trouxe resultados diversos. O registro instituído no Ministério da Justiça não funcionou, porque as informações enviadas pelos tribunais não foram compiladas, ao passo que o registro da Prefeitura da Polícia parisiense se mostrou mais eficiente, pois assimilou as regras trazidas pela lei, embora, também, padecesse das dificuldades antes apontadas. Foram feitas tentativas para a superação dos problemas mediante o emprego da ficha móvel e dos boletins, mas as dificuldades somente foram solucionadas em 1848, por Bonneville de Marsangy, cujas idéias relacionadas ao registro criminal se irradiaram para outros países, como Alemanha, Áustria, Itália e Portugal, entre outros. ${ }^{156}$

O fornecimento das informações relativas ao passado dos acusados durante muito

\footnotetext{
${ }^{153}$ COSTA, António Manuel de Almeida, op. cit., p. 90-91.

${ }^{154}$ GROSSO GALVAN, Manuel, op. cit., p. 17.

${ }^{155}$ COSTA, António Manuel de Almeida, op. cit., p. 91.

${ }^{156}$ Id., ibid., p. 92-94.
} 
tempo foi prestado pela polícia francesa. Referida prática sofreu reflexos da edição da Lei, de 5 de março, e pelo Decreto 7-12, de agosto, ambos de 1848, nos quais se estabelecia, respectivamente, o sufrágio universal e a composição do júri. A partir de então, como o exercício do direito de voto e das funções de jurado poderia ser afetado pelas interdições decorrentes de condenações criminais, ${ }^{157}$ surgiu a necessidade de dotar o sistema de maior eficácia e segurança, condições não alcançadas quando o fornecimento das informações era prestado pela polícia.

As principais idéias relativas à organização do registro criminal foram apresentadas por Bonneville de Marsangy, Procurador da República em Versailles, em discurso proferido em 5 de novembro de 1848. Ele propôs que os serviços de registro criminal deveriam ser executados pelos vários tribunais das comarcas dispersadas pelo país, devendo cada um deles manter o cadastro das pessoas nascidas nas mencionadas localidades. Foram expostos alguns argumentos favoráveis à idéia, entre eles, a agilização das consultas, a repartição dos trabalhos entre o pessoal dos diversos tribunais, redução do risco de eventual perda da totalidade dos registros por não reuni-los em único local sujeito a danos e tragédias e, ainda, a centralização das informações úteis ao serviço judiciário. ${ }^{158}$

O registro criminal francês, conhecido como casier judiciarie, alcançou concepção geral e sistematização a partir da Lei, de 14 de agosto de 1885, cujo objetivo principal foi normatizar a reabilitação, ${ }^{159}$ mas incidentalmente tratou do registro em virtude da proximidade dos temas.

Aliadas à satisfação das necessidades dos serviços judiciários, também surgiram à época ponderações no âmbito da política criminal em razão do amplo acesso ao conteúdo das informações compiladas no registro criminal. Argumentava-se que o acesso irrestrito desvirtuava o registro da sua finalidade técnica de servir como acervo de informações disponíveis à justiça, transformando-o em punição autônoma e meio eficaz de reprimir e prevenir práticas criminosas. As pessoas honestas não queriam seus nomes nele inscritos e intimidavam-se a cometer crimes e, conseqüentemente, sofrer condenações, pois seus efeitos eram diretamente sentidos em razão da publicidade do registro, em especial, nas localidades menos populosas. ${ }^{160}$

$\mathrm{Na}$ época da sua criação, o registro criminal francês tinha as seguintes

\footnotetext{
${ }^{157}$ COSTA, António Manuel de Almeida, op. cit., p. 94-95.

${ }^{158}$ Id., ibid., p. 96.

${ }^{159}$ GROSSO GALVAN, Manuel, op. cit.,p. 235.

${ }^{160}$ COSTA, António Manuel de Almeida, op. cit., p. 97.
} 
características:

a) a organização do ficheiro era atribuição do escrivão de cada tribunal, que deveria arquivar por ordem alfabética os boletins dos quais constavam os dados referentes às condenações criminais, correicionais, militares e marítimas proferidas pelos juízos, além das medidas disciplinares, declarações de falências e reabilitações relativas às pessoas nascidas naquela circunscrição;

b) o escrivão do tribunal da condenação ou dos serviços que fixassem qualquer sanção sujeita a registro encaminhava ao procurador-geral o boletim, no qual havia a identificação da pessoa, o resumo do caso e a pena aplicada. Depois de examinado pelo procurador, o boletim era encaminhado ao tribunal do local onde a pessoa era natural e, no caso de a localidade ser indeterminada ou tratarse de estrangeiro, o registro era mantido em compartimento adequado no próprio tribunal do local em que se decretou a condenação;

c) o acesso aos dados constantes do registro estava à disposição dos tribunais e, ainda, era livre ao interessado e aos terceiros (pessoas ou instituições) em razão da publicidade que se pretendia imprimir ao registro. ${ }^{161}$

A Lei, de 5 de agosto de 1899, modificada pela Lei, de 11 de julho de 1900, completou e estabilizou o regime jurídico do registro criminal na França, porque restringiu ao titular do cadastro o fornecimento de algumas informações e fixou prazos a partir dos quais alguns dados referentes à condenação anotada não deveriam ser divulgados. ${ }^{162}$

A França, portanto, no final do século XIX, buscava soluções para o melhor funcionamento do registro criminal e proteção dos dados individuais e, conseqüentemente, a preservação da privacidade daquele cujo nome foi inserido nos arquivos. No Brasil, entretanto, pouco mais de uma década antes, a Lei Áurea definia a respeito da libertação dos escravos negros. A comparação feita não tem outro objetivo senão demonstrar quanto é preciso aqui caminhar para alcançar-se o nível de desenvolvimento jurídico, humano, social e cultural logrado muito tempo atrás por outras nações.

Importa ressaltar que a Espanha, por sua vez, instituiu seu registro criminal sob a denominação de Registro Central de Penados y Rebeldes. Ele foi implantado em meados do final do século XIX e início do século XX, especificamente pela Real Ordem, de 5 de dezembro de 1892, que organizou o sistema . Antes disso, dentro das suas limitações, as

\footnotetext{
${ }^{161}$ COSTA, António Manuel de Almeida, op. cit.,p. 99-100.

162 Id., ibid., p. 102-103.
} 
informações acerca dos antecedentes criminais eram extraídas dos Libros-Registros de Tribunales y Audiencias. ${ }^{163}$

De modo geral, o sistema francês produzia bons resultados e expandia-se aos demais países, permitindo o controle da reincidência e das interdições decorrentes das sentenças, além de atender as crescentes exigências da prevenção especial. Daquela época até os dias de hoje, não foram muitas as alterações introduzidas no registro criminal em razão do reduzido debate do tema pela doutrina e da dificuldade que a sociedade tem para tratar das questões relacionadas aos ex-condenados, de modo geral. ${ }^{164}$

O registro criminal, inspirado no pioneiro sistema francês, evoluiu como instituto independente cuja finalidade era auxiliar a justiça penal sem excluir o auxílio prestado à investigação criminal desenvolvida pela polícia. ${ }^{165}$

\subsection{Origem do registro criminal em Portugal}

Em Portugal, o desenvolvimento do registro criminal seguiu o sistema francês, dele não se distanciando muito no tempo.

Relata-se, entretanto, que no reinado de Dom Dinis, no ano de 1263, havia uma lei que determinava a inscrição das sentenças judiciais no "livro dos culpados". O objetivo da medida, de início, não foi o conhecimento dos antecedentes das pessoas condenadas, mas o controle da forma de atuação dos juízes. Com o tempo, o mencionado livro transformou-se em fonte de pesquisa dos antecedentes e serviu como sustentáculo para outras leis que tratavam do tema. A primeira forma portuguesa de registro criminal decorreu do Alvará, de 30 de Junho de 1511, por meio do qual se criou o "ofício de corredor de folhas da casa do cível" e se previu a tramitação dos pedidos de informações a respeito do acusado. Para tanto, seria expedida uma folha aos demais tribunais para que informassem aquilo que constasse depois da verificação dos seus livros. ${ }^{166}$

As Ordenações Filipinas e a Novíssima Reforma Judicial mantiveram e aperfeiçoaram o sistema da folha corrida, ampliando o número de repartições que deveriam prestar informações a respeito da consulta. Nesse período, também, foi determinado aos

\footnotetext{
${ }^{163}$ GROSSO GALVAN, Manuel, op. cit., p. 18 e 129.

${ }^{164}$ COSTA, António Manuel de Almeida, op. cit., p. 104.

${ }^{165}$ VEIGA, Catarina, op. cit., p. 58.

${ }^{166}$ COSTA, António Manuel de Almeida, op. cit., p. 104-107.
} 
tribunais cadastrar suas decisões, providência materializada no "livro" ou "rol dos culpados" ou "folha de culpas", com o objetivo de certificar se em nome do acusado constava alguma condenação anterior. Do mesmo modo que ocorrera na França, antes de 1850, o sistema vigente em Portugal nessa época se mostrou precário em razão da pulverização das informações nos cadastros dos tribunais portugueses e da morosidade decorrente das buscas feitas nos livros. Pretendeu-se enfrentar referidas dificuldades com o Decreto, de 25 de Maio de 1825, que determinou a centralização dos registros policiais na Intendência Geral da Polícia cujo funcionamento, também, não foi adequado em virtude de não suprir a necessidade dos tribunais e porque a polícia não tinha organização unitária até $1918 .^{167}$

A necessidade de dispensar melhor trato ao registro criminal para a obtenção de informações seguras e abrangentes foi sentida a partir do final do século XVIII e início do século XIX quando foi notada a importância da avaliação dos antecedentes do autor da prática infracional. Nessa época, em que se aproveitavam os efeitos do Iluminismo e da Revolução Francesa, foi verificada a importância das ações que privilegiassem a prevenção especial e o conhecimento dos antecedentes pessoais do réu, pensamentos cristalizados em Portugal depois da adoção do sistema de Bonneville de Marsangy por meio de decretos editados em 1863 e 1872 nos quais se ressaltou a imperiosidade do conhecimento dos antecedentes judiciários dos criminosos pelos tribunais. ${ }^{168}$

A partir da segunda metade do século XIX, período em que o registro criminal foi instituído em Portugal, buscou-se criar mecanismos para que o seu funcionamento facilitasse o trabalho judicial de fixar a pena imposta aos infratores, bem como ajudasse controlar e provar a reincidência e as interdições decorrentes de sentença condenatória. À época, ainda, salientavam-se os benefícios que a adoção do registro criminal poderia trazer ao sistema de estatística judiciária e à cooperação internacional no âmbito criminal. Não havia, entretanto, demonstração de que o uso dos registros tivesse a finalidade de causar efeito infamante às pessoas cadastradas, como ocorreu na França, pois, em Portugal, a infâmia decorrente da inserção do nome no registro era considerado efeito desproporcional ou injusto. ${ }^{169}$

Em linhas gerais, os diplomas legais que regulamentavam o registro criminal em Portugal, datados de 1863 e 1872, traçavam regras para operacioná-lo.

\footnotetext{
${ }^{167}$ COSTA, António Manuel de Almeida, op. cit., p. 108-109.

${ }^{168}$ Id., ibid., p. 110-114.

${ }^{169}$ Id., ibid., p. 117-120.
} 
Mencionados decretos previam a instituição de ficheiros formados a partir dos boletins, arquivados em ordem alfabética, conservados nas secretarias dos delegados do Procurador da Coroa no Ultramar, ou nos tribunais de primeira instância. O critério da naturalidade do condenado também era observado para o arquivamento do registro, sendo previsto o intercâmbio entre as diversas autoridades locais responsáveis pelo controle dos dados e, ainda, a existência do registro central, capaz de armazenar os boletins referentes aos nacionais nascidos no estrangeiro e nas colônias, estrangeiros, pessoas naturalizadas e nascidas em localidades não declaradas. Os dados contidos nos ficheiros se exteriorizavam por intermédio de um modelo único de certificado para o qual eram transcritos os dados neles existentes, abrangendo, ainda, mesmo as decisões reabilitadas, decisões disciplinares, falência e interdições civis. ${ }^{170}$

Os referidos decretos traçaram as linhas mestras do registro criminal português cujos delineamentos persistem até hoje, somente alterados por mudanças político-criminais ou para incorporar inovações decorrentes da evolução técnica. Ao longo do tempo, caminhou-se para a restrição da publicidade dos dados, especialmente em razão de consultas privadas, bem como, para o controle da reabilitação e do cancelamento das inscrições. No campo evolutivo, partiu-se para a centralização dos serviços e, ultimamente, para a computadorização do setor. ${ }^{171}$

A análise das inovações trazidas por alguns diplomas legais portugueses permite acompanhar as tendências da evolução do registro criminal nesse país.

Inicialmente, cabe consignar que o Decreto, de 17 de Março de 1906, foi reflexo das divergências entre aqueles que pretendiam a vedação das informações em relação aos particulares e os que advogavam a favor da publicidade restrita, orientando esta tendência mais equilibrada a redação desse diploma legal. Esse Decreto inovou em distinguir a entidade requerente e, dependendo do seu status, permitir-lhe maior ou menor quantidade de informações. Desse modo, aos magistrados judiciais e do Ministério Público, à polícia e a entidades administrativas que exerciam funções de judicatura era fornecida a transcrição integral do registro. Os dados eram transmitidos às autoridades públicas necessitadas de conhecer se havia interdições ou incapacidades determinadas judicialmente, enquanto, finalmente, aos particulares, o conteúdo das informações contidas no certificado era limitado e dependia da prévia autorização judicial.

\footnotetext{
${ }^{170}$ COSTA, António Manuel de Almeida, op. cit., p. 122-124.

${ }^{171}$ Id., ibid., p. 122-123.
} 
Algumas outras inovações foram trazidas pelo Decreto mencionado, tais como o registro da pena suspensa (sursis) e do livramento condicional, além da possibilidade do cancelamento do cadastro. Quanto ao cancelamento, a determinação poderia decorrer da via administrativa ou legal. A primeira era condicional, porque exigia a demonstração do bom comportamento e poderia ser revogável pela má conduta do interessado. A segunda, por seu turno, era automática e requeria o decurso de prazo a contar da extinção da pena, desde que o interessado não praticasse novos crimes. $\mathrm{O}$ cancelamento, nas duas situações, somente era permitido se a pessoa não ostentasse no seu registro outra anotação. ${ }^{172}$

O Decreto-Lei $\mathrm{n}^{\mathrm{o}} 27.304$, de 8 de Dezembro de 1936, centralizou o registro criminal e policial no Arquivo Geral do Registro Criminal e Policial, sediado em Lisboa, sob a argumentação de que a manutenção dos registros em ficheiros parciais era propícia às fraudes mediante expedientes simples, como a mudança do nome. Um dos efeitos práticos mais sentidos pela mudança foi a redução dos esforços, antes necessários, para formar o registro criminal e policial, acrescido do cuidado da não-divulgação das detenções e infrações não-penais anotadas pela polícia, exceto quando o solicitante fosse autoridade judiciária ou houvesse a finalidade de instruir investigação policial. Noutro aspecto, esse decreto-lei instituiu o regime de reabilitação administrativa permitindo a total exclusão das informações nos certificados expedidos, de tal modo que as decisões reabilitadas não poderiam servir como supedâneo para a medida da pena, verificação da reincidência ou habitualidade criminosa, restringindo mais ainda a publicidade do cadastro. ${ }^{173}$

Até meados de 1970, as últimas alterações sensíveis no registro criminal em Portugal foram trazidas pelos Decretos-Leis $\mathrm{n}^{\mathrm{os}}$ 41.077, de 19 de Abril de 1957, e 251, de 11 de Junho de 1971.

O primeiro deslocou o cadastro para a Direcção dos Serviços de Identificação, ao passo que o segundo teve como principal finalidade adaptar o sistema às inovações decorrentes do emprego do computador, experimentadas antes para a identificação civil, bem como fixou e direcionou a inserção dos dados no registro criminal para as matérias eminentemente penais, afastando a necessidade da anotação das contravenções não punidas com prisão, mesmo em caso de reincidência. Referida alteração devia-se ao interesse em reduzir o cadastro, pois era sabido que setenta por cento das anotações existentes à época, ou seja, dois milhões de cadastros, decorria da prática das contravenções penais. Assim, ganhavam força as idéias de encaminhar as contravenções para outra esfera de controle que

${ }^{172}$ COSTA, António Manuel de Almeida, op. cit., p. 125-127.

${ }^{173}$ Id., ibid., p. 128-131. 
não o penal e, ainda, de reduzir desigualdades na aplicação da justiça decorrente da capacidade econômica do infrator, porque somente os casos de contravenções cuja pena de multa não era paga ficavam sujeitas ao cadastro. ${ }^{174}$

A reunião dos cadastros das comarcas foi iniciada em 1936 pela criação do Arquivo Geral de Identificação Criminal e Policial e, a partir disso, os ficheiros regionais foram substituídos pelo central de modo lento e progressivo. Trata-se de serviço autônomo e independente, não vinculado a qualquer outro órgão ou departamento cuja direção é exercida por um funcionário ao qual se atribuem as tarefas de receber as reclamações e dirimir os casos duvidosos, permitindo-se, nesse caso, a interposição de recurso ao Tribunal de Execução das Penas. ${ }^{175}$

Em Portugal, a inscrição das decisões no registro é automática. Algumas anotações, em razão da diminuta gravidade ou do interesse na reintegração social da pessoa, podem não constar das certidões expedidas para fins determinados, procedendo-se desse modo à determinação judicial. Mesmo nessas hipóteses, a regra do automatismo do registro é preservada, porque é restrita somente a divulgação da anotação e não sua inscrição. ${ }^{176}$

A identificação e o registro criminal português estão regulados pela Lei 57/98, de 18 de Agosto, ${ }^{177}$ texto que traz algumas abordagens peculiares do segundo tema, objeto deste estudo, as quais serão referidas ao longo desta exposição, inclusive ao discutirem-se as propostas para a estruturação do registro criminal brasileiro.

Também em Portugal, o Decreto-Lei $n^{0}$ 381/98, de 27 de Novembro, regulou o regime jurídico da identificação criminal e de contumazes, além do funcionamento do registro criminal. $\mathrm{O}$ texto que introduz esse decreto-lei ressaltou estar o registro criminal nesse país ainda regulado pelo Decreto-Lei $n^{0}$ 39/83, de 25 de Janeiro, publicado logo depois do Código Penal de 1982 a fim de harmonizar o regime do registro criminal com as alterações penais, embora referido Código não tenha alterado profundamente o regime anteriormente vigente que disciplinava o registro criminal. ${ }^{178}$

\footnotetext{
${ }^{174}$ COSTA, António Manuel de Almeida, op. cit., p. 136-137.

${ }^{175}$ Id., ibid., p. 163.

${ }^{176}$ Id., ibid., p. 164.

${ }^{177}$ VEIGA, Catarina, op. cit., p. 145-158.

${ }^{178}$ Diário..., cit., p. 6576.
} 


\subsection{Origem do registro criminal no Brasil}

É difícil traçar a linha evolutiva do registro criminal no Brasil, porque aqui o assunto não sofreu desenvolvimento legislativo intenso, como ocorreu nos referidos países da Europa, e foi pouco tratado pela doutrina nacional.

Apesar disso, pela análise da legislação processual penal e dos textos publicados por determinados autores é permitido conhecer os aspectos essenciais do registro no País e visualizar sua evolução.

Toma-se como ponto de partida para analisar a origem do registro criminal no Brasil as providências que as autoridades deveriam adotar em relação ao preso, descritas no Livro V, Título CXXI, das Ordenações do Reino, do Código Filipino, ao dispor "que ao tempo da prisão se faça o acto do habito, e tonsura do preso". ${ }^{179}$ No "acto do habito, e tonsura do preso" descreviam-se os "vestidos, e trajos em que forem achados, e as cores e feição, e comprimento delles, declarando se trazem coroa, e o tamanho, e comprimento dos cabellos della, e quanto mais curtos são que os outros cabellos da cabeça". ${ }^{180}$

Mais adiante, o Título CXXV, da mesma legislação, indica "como se correrá a folha dos que forem presos por feito crime", impondo essa obrigação ao escrivão do lugar da prisão. $^{181}$

O ofício "dos corredores das folhas das Casas da Suplicação e do Porto e da Cidade de Lisboa" foi descrito no Título LVI, das Ordenações Filipinas, que determinava o exercício cuidadoso das atividades, indelegáveis a qualquer outra pessoa, tanto que, em caso de doença do titular do ofício, outra pessoa seria indicada oficialmente para cumprir sua tarefa. A procedência distante dessa função é encontrada no Alvará, de 30 de julho de 1511, ao qual the foi feita referência quando do estudo da origem do registro criminal em Portugal. A legislação previa que a obtenção das informações relativas aos antecedentes criminais dos presos deveria ser realizada com rapidez, pois dispunha que "dentro em 8 dias do dia da prisão, ao mais, seja a folha de todo corrida, e tirada tôda dúvida" e, caso

${ }^{179}$ FERREIRA, Aurélio Buarque de Holanda. Dicionário eletrônico Aurélio - Século XXI. Rio de Janeiro: MGB Informática, 1999. 1 CD-ROM. Produzido por Lexikon Informática. Essa mídia indica que a expressão "tonsura" tem origem na palavra latina tonsura e significa "corte circular, rente, do cabelo, na parte mais alta e posterior da cabeça, que se faz nos clérigos; cercilho, coroa" e, também, que "prima tonsura" é "cerimônia religiosa em que o prelado, conferindo ao ordinando o primeiro grau de clericato, lhe dá a tonsura."

${ }^{180}$ PIERANGELI, José Henrique. Códigos Penais do Brasil. Evolução histórica. 2. ed. São Paulo: RT, 2004. p. 188.

${ }^{181}$ Id., ibid., p. 197. “O preso por feito crime não será solto, sem primeiro se correr delle folha pelos Scrivães do lugar, onde tiver sido preso, na forma que dissemos no Livro 1, tir. 56: Dos Corredores das folhas." 
fossem os corredores das folhas negligentes, "os Julgadores procederão contra eles com penas pecuniárias e suspensão de seus Ofícios, como lhes parecer". ${ }^{182}$

Não há referência segura acerca da influência das "folhas corridas" nos julgamentos realizados nessa época, podendo considerar-se aquelas como "documentos que eram levados pelos corredores de folhas [...] oficial incumbido de correr as escrivanias e ver se havia ali crimes em aberto". ${ }^{183}$

O "acto do habito e tonsura do preso" foi substituído posteriormente pelo "auto de qualificação e identidade do réo", tratado no Código de Processo Criminal do Império, de 1832. O "auto de qualificação e identidade do réo" servia para o juízo certificar e ter prova da identidade do preso, bem como conhecer a "reincidência de crimes, quando isso aconteça, e para os dados necessários da estatística criminal, além de outros esclarecimentos a que pode dar logar". ${ }^{184}$

As ordenações e a legislação processual do período imperial continham regras para conhecer e fixar a identidade do preso e descobrir-lhe eventuais condenações anteriores, podendo nelas visualizar-se o embrião dos sistemas de identificação e registro criminal nacional.

Mais recentemente, o Código de Processo Penal em vigor desde 1942 (Decreto-Lei $\mathrm{n}^{\mathrm{o}} 3.689$, de 1941) ${ }^{185}$ também trouxe alguns dispositivos relacionados ao registro criminal. Neste ponto do estudo, cujo objetivo é investigar a origem histórica do instituto no cenário nacional, será enfatizado o conteúdo desses artigos e serão ressaltados os comentários da doutrina sobre eles.

A partir do mandamento inserido no artigo $6^{\circ}$, inciso VIII, do Código de Processo Penal, ${ }^{186}$ Eduardo Espínola Filho esclareceu ser obrigação da autoridade policial, entre

182 ALMEIDA, Fernando H. Mendes de. Ordenações Filipinas. Ordenações e leis do Reino de Portugal recopiladas por mandado d'el Rei D. Felipe, o Primeiro. São Paulo: Saraiva, 1957. v. 1, p. 257-258.

${ }^{183}$ BISSOLI FILHO, Francisco, op. cit., p. 60.

184 BUENO, José Antonio Pimenta (Marquez de S. Vicente). Apontamentos sobre o processo criminal brasileiro. 4. ed. annotada pelo Dr. Vicente Ferrer de Barros W. Araújo. Lisboa: Livraria Clássica Editora de A. M. Teixeira \& C., 1910.p. 179.

${ }^{185}$ Francisco Bissoli Filho (op. cit., p. 60) aponta que "O Direito Positivo Penal, Processual Penal e de Execução Penal brasileiros, fez consignar disposições expressas sobre os antecedentes apenas a partir do Código de 1940, ocasião em que os mesmos passaram a compor o rol de fatores a serem considerados na individualização da pena." Referida observação é importante, na medida em que justifica a dificuldade de reunirem-se referências escritas acerca do registro criminal brasileiro anteriores ao mencionado período (meados de 1940), conforme anteriormente observado neste texto.

186 “Art. $6^{\circ}$. Logo que tiver conhecimento da prática da infração penal, a autoridade policial deverá: [...]

VIII - ordenar a identificação do indiciado pelo processo datiloscópico, se possível, e fazer juntar aos autos sua folha de antecedentes;" 
outras, juntar à investigação a "fôlha de antecedentes judiciários".

Analisando o artigo 23 da lei processual penal, ${ }^{187}$ o autor ensinou que a identificação permitia "o conhecimento da vida judiciária anterior do indiciado" e noticiava ao "instituto competente a circunstância de estar sendo suspeitado da atual transgressão penal", além de obrigar a autoridade policial comunicar ao Instituto de Identificação e Estatística, ou repartição congênere, ao remeter o inquérito policial ao juízo, os dados pessoais do indiciado e a indicação da infração penal na qual foi incurso. ${ }^{188}$ Por fim, ao comentar o artigo 809 do Código de Processo Penal, ${ }^{189}$ consignou que a decisão da causa será comunicada pelo juízo ao referido Instituto por meio do boletim individual. Esse documento, citado no caput e no último parágrafo do artigo mencionado, foi considerado pelo legislador como a "base da estatística judiciária", que não tratou da sua função de servir como meio de transmissão ao registro das informações relacionadas aos inquéritos policiais e processos criminais. ${ }^{190}$

Eduardo Espínola Filho também discorreu a respeito do "registo e as averbações referentes ao sursis e aos seus efeitos, nos livros do Instituto de Identificação, ou repartição

\footnotetext{
187 “Art. 23. Ao fazer a remessa dos autos do inquérito ao juiz competente, a autoridade policial oficiará ao Instituto de Identificação e Estatística, ou repartição congênere, mencionando o juízo a que tiverem sido distribuídos, e os dados relativos à infração penal e à pessoa do indiciado."

${ }_{188}$ Código de Processo Penal brasileiro anotado. 6. ed. Rio de Janeiro: Borsoi, 1965. v. I, p. 287.

189 “Art. 809. A estatística judiciária criminal, a cargo do Instituto de Identificação e Estatística ou repartições congêneres, terá por base o boletim individual, que é parte integrante dos processos e versará sobre:

I - os crimes e as contravenções praticados durante o trimestre, com especificação da natureza de cada um, meios utilizados e circunstâncias de tempo e lugar;

II - as armas proibidas que tenham sido apreendidas;

III - o número de delinqüentes, mencionadas as infrações que praticaram, sua nacionalidade, sexo, idade, filiação, estado civil, prole, residência, meios de vida e condições econômicas, grau de instrução, religião, e condições de saúde física e psíquica;

IV - o número dos casos de co-delinqüência;

$\mathrm{V}-$ a reincidência e os antecedentes judiciários;

VI - as sentenças condenatórias ou absolutórias, bem como as de pronúncia ou de impronúncia;

VII - a natureza das penas impostas;

VIII - a natureza das medidas de segurança aplicadas;

IX - a suspensão condicional da execução da pena, quando concedida;

$\mathrm{X}$ - as concessões ou denegações de habeas corpus.

$\S 1^{\circ}$. Os dados acima enumerados constituem o mínimo exigível, podendo ser acrescidos de outros elementos úteis ao serviço da estatística criminal.

$\S 2^{\circ}$. Esses dados serão lançados semestralmente em mapa e remetidos ao Serviço de Estatística Demográfica Moral e Política do Ministério da Justiça.

* Redação do $\S 2^{\circ}$ determinada pela Lei nº 9.061, de 14 de junho de 1995.

$\S 3^{\circ}$. O boletim individual a que se refere este artigo é dividido em três partes destacáveis, conforme modelo anexo a este Código, e será adotado nos Estados, no Distrito Federal e nos Territórios. A primeira parte ficará arquivada no cartório policial; a segunda será remetida ao Instituto de Identificação e Estatística, ou repartição congênere; e a terceira acompanhará o processo, e, depois de passar em julgado a sentença definitiva, lançados os dados finais, será enviada ao referido Instituto ou repartição congênere.”

${ }^{190}$ Op. cit., v. IX, p. 99.
} 
congênere" previstos no artigo 709 do Código de Processo Penal. ${ }^{191}$ Em sua obra, o autor enfatizou ser "absolutamente secreta a consignação do fato delituoso, da ação penal e do seu resultado" e ensinou que o sigilo somente seria quebrado no caso de imposição cumulativa de pena acessória de interdição de direito à época prevista pela lei penal ou de novo processo criminal. Acentuou que estivesse o acusado gozando sursis e fosse submetido a processo para apurar novo crime aquela informação seria fornecida ao "juiz processante, unicamente". ${ }^{192}$

Ao estudar o processo criminal brasileiro, João Mendes de Almeida Júnior referiu-se à obrigação da autoridade policial juntar a folha de antecedentes, inscrita no artigo $6^{\circ}$, inciso VIII, ${ }^{193}$ enquanto Antonio Bento de Faria tratou das estatísticas criminais e do boletim individual mencionado pelo artigo 809 do Código de Processo Penal. ${ }^{194}$

Hélio Tornaghi considerou que a juntada da folha de antecedentes ao inquérito policial, na forma prevista pelo artigo $6^{\circ}$, inciso VIII, do Código de Processo Penal, auxiliava individualizar a pena, verificar a periculosidade e aferir sobre a concessão do sursis. Entendia que o mandamento do artigo 23 possibilitava formar o cadastro de antecedentes, tarefa regulada pelo artigo 809, ambos do Código de Processo Penal. ${ }^{195}$

As referências aos artigos do Código de Processo Penal e comentários da doutrina clássica permitem notar que o legislador de 1941 traçou algumas regras variadas e indiretas para tratar do registro das pessoas envolvidas com crimes, porque determinou a juntada dos antecedentes criminais do investigado ao inquérito e cuidou de inserir no cadastro de antecedentes os dados relacionados à investigação. A seguir, dispôs sobre a estatística da reincidência e dos antecedentes e criou o boletim individual como meio atualizador do cadastro a partir do desfecho da ação penal.

\footnotetext{
191 “Art. 709. A condenação será inscrita, com a nota de suspensão, em livros especiais do Instituto de Identificação e Estatística, ou repartição congênere, averbando-se, mediante comunicação do juiz ou do tribunal, a revogação da suspensão ou a extinção da pena. Em caso de revogação, será feita a averbação definitiva no registro geral.

$\S 1^{\circ}$. Nos lugares onde não houver Instituto de Identificação e Estatística ou repartição congênere, o registro e a averbação serão feitos em livro próprio no juízo ou no tribunal.

$\S 2^{\circ}$. O registro será secreto, salvo para efeito de informações requisitadas por autoridade judiciária, no caso de novo processo.

$\S 3^{\circ}$. Não se aplicará o disposto no $\S 2^{\circ}$, quando houver sido imposta ou resultar de condenação pena acessória consistente em interdição de direitos."

${ }^{192}$ ESPÍNOLA FILHO, Eduardo. Código de Processo Penal brasileiro anotado. 6. ed. Rio de Janeiro: Borsoi, 1965. v. VIII, p. 116. Cf., também, NORONHA, Edgard Magalhães. Curso de direito processual penal. 18. ed. São Paulo: Saraiva, 1987. p. 457.

${ }^{193}$ O processo criminal brasileiro. 4. ed. Rio de Janeiro e São Paulo: Freitas Bastos, 1959. v. I, p. 280-281 e v. II, p. 91-94.

${ }^{194}$ Código de Processo Penal. 2. ed. Rio de Janeiro: Record, 1960. v. III, p. 147-148.

${ }^{195}$ Comentários ao Código de Processo Penal. Rio de Janeiro: Forense, 1956. v. I, t. 1, p. 167 e 191-192.
} 
Entretanto, somente em um artigo da lei processual o legislador preocupou-se em restringir o acesso ao registro e proteger a privacidade das pessoas, pois atribuiu caráter relativamente secreto à anotação do sursis. Além disso, sintomaticamente, a expressão registro criminal não foi empregada pelo legislador de 1941 na redação do Código de Processo Penal, embora fosse a denominação conhecida à época, tanto que o Decreto $\mathrm{n}^{\mathrm{o}}$ 11.285, de 5 de agosto de 1940, organizou o registro criminal no Estado de São Paulo. ${ }^{196}$

"O equilíbrio entre o interesse social e o da defesa individual, entre o direito do Estado à punição dos criminosos e o direito do indivíduo às garantias e seguranças de sua liberdade", descritos no item XVIII da Exposição de Motivos do Código de Processo Penal como "espírito do Código" não refletiu, integralmente, nos artigos dessa lei relacionados ao registro criminal, porque neles é possível notar defesa intensiva do interesse social em detrimento do individual, especialmente pela lei processual penal deixar de assegurar expressamente caráter sigiloso a todo conteúdo do registro, prevendo-o somente aos casos de sursis.

\subsection{O registro criminal na Itália ${ }^{197}$}

$\mathrm{Na}$ Itália, as questões relativas ao registro criminal, conhecidas como casellario giudiziale, encontram as suas linhas mestras reguladas entre os artigos 685 a 690 do Codice di Procedura Penale.

O sistema previsto na legislação processual italiana dispõe que junto a cada tribunal, sob a fiscalização do Procurador da República, existirá um uficcio del casellario giudiziale cuja função é recolher e conservar os provimentos e anotações em relação às pessoas nascidas naquela circunscrição. Os registros relativos aos estrangeiros ou nascidos em localidade incerta são remetidos ao tribunal de Roma.

A lei processual penal italiana dispõe que, além das determinações previstas em outros diplomas legislativos, em matéria penal serão inscritas no casellario giudiziale:

a) as sentenças penais condenatórias definitivas, exceto se referir-se à contravenção, desde que não seja concedida a suspensão condicional da pena;

\footnotetext{
${ }^{196}$ SÃO PAULO (Estado). Decreto n ${ }^{\circ} 11.285$, de 5 de agosto de 1940. Lex: Coletânea de legislação, São Paulo, v. 4, p. 133-134, 1940.

${ }^{197}$ ITALIA. Codice di Procedura Penale. Disponível em:

$<$ http://www.studiocelentano.it/codici/cpp/1p/casellario.htm>. Acesso em: 11 jun. 2005.
} 
b) as decisões definitivas dos órgãos de execução penal relativas à pena, à medida de segurança, aos efeitos penais da condenação, à concessão de anistia e à declaração de habitualidade ou profissionalidade no crime ou de tendência a delinqüir;

c) as decisões relativas às penas acessórias;

d) as sentenças definitivas que reconhecerem a inimputabilidade, fixada medida de segurança ou declarado extinto o crime pela aplicação de sanção substitutiva a pedido do acusado.

O casellario giudiziale também admite inserção de informações em matéria civil nos seguintes casos:

a) as sentenças transitadas em julgado de interdição e de inabilitação e as decisões revogatórias;

b) as sentenças declaratórias da falência;

c) as sentenças homologatórias da concordata falimentar e aquelas que declararam a reabilitação do falido;

d) os decretos de prisão do falido;

e) os provimentos administrativos relativos à perda ou revogação da cidadania e expulsão de estrangeiros;

f) os provimentos definitivos relativos à aplicação das medidas de prevenção da sorveglianza especial simples ou com divieto od obbligo di soggiorno.

Serão inscritas, ainda, desde que reconhecidas pela autoridade judiciária, as sentenças pronunciadas pelas autoridades judiciárias estrangeiras.

No casellario giudiziale, quando se tratar de condenação penal, faz-se menção ao lugar e ao período em que a pena foi descontada, bem como à eventual aplicação de medida alternativa à prisão ou referência do seu não-cumprimento integral por anistia, indulto, graça, liberdade condicional ou outra causa. Deverão ser inscritos, também, os provimentos declaratórios ou revogatórios da reabilitação.

Os registros do casellario giudiziale serão excluídos quando houver notícia oficial da morte da pessoa ou nos casos do transcurso de lapso temporal de oitenta anos a contar do nascimento da pessoa.

Também é possível eliminar inscrições nas seguintes situações: 
a) condenação revogada por revisão ou no caso de abolitio criminis;

b) sentença que reconheceu a inimputabilidade, desde que transcorridos dez e três anos, respectivamente, para a prática de crimes e de contravenções;

c) imposição de multa exclusiva pela prática de contravenção, desde que transcorrido lapso de dez anos de extinção da pena, salvo nos casos em que o juiz houver concedido suspensão condicional da pena ou declarar a não-menção da condenação no certificado do casellario giudiziale conforme dispõem os artigos 163 e 175, ambos do Código Penal italiano.

O último dispositivo citado do Código Penal faculta ao juiz na sentença ordenar que não seja feita menção à condenação imposta, quando as circunstâncias judiciais são favoráveis ao acusado que é condenado pela primeira vez ao cumprimento de pena detentiva não superior a dois anos ou ao pagamento de pena pecuniária cujo valor é limitado pela lei.

Existe previsão legal, ainda, para a eliminação de inscrições civis (artigo 687, número 3, bis, do Código de Processo Penal italiano).

A legislação italiana concede aos órgãos da jurisdição penal e ao Ministério Público, para fins penais, bem como à administração pública e aos entes encarregados do serviço público, em razão da prática de atos inerentes às suas funções, obterem certificado do casellario giudiziale. É permitido fornecer ao Ministério Público o mencionado certificado referente à pessoa investigada, acusada ou condenada e faculta-se ao mesmo órgão e ao defensor requererem ao juiz o certificado do casellario giudiziale em relação ao ofendido ou à testemunha para os fins previstos no artigo 236 da legislação processual penal italiana. ${ }^{198}$

Essa legislação também ressalva no campo eleitoral que os certificados expedidos para esses fins somente deverão fazer menção à condenação e outros provimentos que tenham influência na esfera do direito eleitoral.

O artigo 689 do Codice di Procedura Penale dispõe, ainda, que o interessado tem direito de requerer os certificados geral, penal e cível, sem motivar o pedido.

No certificado geral serão relacionadas todas as inscrições existentes, exceto:

\footnotetext{
${ }^{198}$ O número 2 do referido artigo faculta o exame de decisões judiciais e certificados do casellario giudiziale para valorar a credibilidade de um testemunho (ITALIA. Codice di Procedura Penale. Disponível em: $<$ http://www.altalex.com/index.php?idnot=36786>. Acesso em: 3 jan. 2008).
} 
a) as condenações nas quais exista determinação para que não sejam mencionadas, conforme dispõe o artigo 175 do Código Penal italiano, quando o benefício não tenha sido revogado;

b) as condenações decorrentes das contravenções penais punidas com pena de multa e as condenações por crimes extintos conforme artigo 167, inciso 1, do Código Penal italiano;

c) as condenações por crimes em que foi verificada a causa especial de extinção prevista no artigo 556 do Código Penal italiano;

d) as condenações cujas penas foram anistiadas e aquelas em que houve a declaração da reabilitação não revogada;

e) as sentenças previstas no artigo 445 do Codice di Procedura Penale ${ }^{199}$ e aquelas cujo crime foi declarado extinto por aplicação de sanção substitutiva mediante pedido do acusado;

f) as condenações decorrentes de fatos não mais considerados crimes quando a inscrição relativa ainda não tenha sido eliminada;

g) os provimentos referentes à aplicação de medida de segurança quando revogados;

h) os provimentos indicados no artigo 686, inciso 1, alínea “b”, número 1, quando a interdição ou a inabilitação foi revogada;

i) os provimentos relativos ao falido quando ele foi reabilitado por sentença definitiva.

No certificado penal, fornecido a pedido do titular do cadastro, não serão anotadas, praticamente, as mesmas exceção acima indicadas, devendo nele incluir-se as informações atinentes às interdições, inabilitações e falências, além daquelas previstas no artigo 686, inciso 1, alíneas "b" e "c", da legislação processual penal italiana.

Por fim, no certificado civil serão inscritas as informações respeitantes à matéria civil e os provimentos administrativos concernentes à perda ou revogação da cidadania e expulsão de estrangeiro, exceto os casos de interdição ou inabilitação revogada ou, ainda,

199 O artigo 445 do Código de Processo Penal italiano trata dos efeitos da aplicação de pena a pedido que consiste na possibilidade de o acusado e o Ministério Público requerem ao juiz, em determinados casos, aplicação da pena conforme dispõe o artigo 444 dessa lei (ITALIA. Codice di Procedura Penale. Disponível em: $<$ http://www.altalex.com/index.php?idnot=36786>. Acesso em: 3 de janeiro de 2008). 
no caso de o falido ter sido reabilitado.

Se o certificado fizer menção a qualquer condenação, deve ser apontada, também, a eventual aplicação de medida alternativa à detenção ou a eventual extinção da pena.

$\mathrm{Na}$ Itália, a legislação criminal oferece as principais características do casellario giudiziale e dita, inclusive, normas relativas ao conteúdo e acesso. O registro italiano, em linhas gerais, funciona paralelamente aos serviços judiciários prestados pelos tribunais locais sob fiscalização da Procuradoria da República, reunindo os dados de interesse criminal das pessoas nascidas naquela localidade.

\subsection{O registro criminal na França ${ }^{200}$}

$\mathrm{Na}$ França, o casier judiciare nacional reúne as anotações referentes às condenações das pessoas físicas e morais, pronunciadas pelas jurisdições penais, tais como as cours d'assises, os tribunais de menores, as cortes de apelação, os tribunais correcionais, os tribunais de polícia, os tribunais e juízos de jovens. O casier judiciare mantém, também, certas decisões proferidas nas jurisdições comerciais (liquidação judicial, falência pessoal e interdição de gerência) além de outras administrativas e disciplinares que geram incapacidade.

Mencionadas anotações são exteriorizadas por meio de extratos denominados bulletins de casier judiciare.

O casier judiciare das pessoas físicas expede três modalidades de boletins.

O boletim número um, exclusivo das autoridades judiciárias, traz o conjunto das condenações e das decisões do casier judiciare, exceto:

a) as condenações pronunciadas em razão da prática das contravenções de polícia, depois do prazo de três anos;

b) as declarações de culpabilidade extraídas da dispensa de pena, depois do prazo de três anos, sendo possível que seja requerido ao juiz, no momento em que determinou a dispensa da pena, que ela não seja inscrita no casier judiciare;

c) as condenações beneficiadas pela anistia ou pela reabilitação;

${ }^{200}$ FRANÇA. Ministère de la Justice. Le Casier judiciaire national. Les extraits des casiers des personnes physiques et morales. Disponível em: <http://www.justice.gouv.fr/cjn/extraits.htm>. Acesso em: 11 de junho de 2005. 
d) as condenações leves pronunciadas contra os menores;

e) os julgamentos em que foram fixadas as sanções comerciais da falência pessoal ou a interdição de gerência depois do prazo de cinco anos, salvo duração mais longa da medida ou quando essas medidas forem apagadas por um julgamento fechado pela extinção do passivo ou pela reabilitação;

f) os julgamentos em que foi determinada a liquidação judicial à vista de uma pessoa física depois de cinco anos;

g) as decisões disciplinares apagadas pela reabilitação.

As condenações penais são retiradas do casier judiciare ao final de um prazo de quarenta anos ou em razão da morte do interessado.

O boletim número dois traz a maior parte das informações existentes no boletim número um, exceto:

a) as condenações pronunciadas na época em que o interessado era menor;

b) as condenações pronunciadas em razão das contravenções de polícia;

c) as condenações em relação às quais foi concedido o sursis, desde que não revogado. Entretanto, se concedido un suivi socio-judiciarie tratado no artigo 131-36-1 do Código Penal francês ${ }^{201}$ ou imposta pena de interdição para o exercício de atividade profissional ou beneficente que demande contato habitual com menores, as informações continuarão figurando no boletim dois no decorrer da duração da medida se ela exceder o prazo do período de prova.

O bulletin número dois só poderá ser enviado a certas autoridades administrativas pelos motivos previamente enumerados, por exemplo, acesso a um emprego público, exercício de certas profissões e obtenção de uma distinção honorífica.

É possível pedir ao juiz, seja no momento da condenação ou em momento posterior, que a condenação não seja inscrita no bulletin número dois, permanecendo no bulletin número um.

O bulletin número três, por sua vez, comporta as condenações mais graves decorrentes da prática de crimes ou delitos, tais como, as decisões decorrentes de

\footnotetext{
${ }^{201}$ Em linhas gerais, referida medida é concedida pelo juiz à pessoa condenada ao cumprimento de pena de prisão que ficará livre, mas submetida às medidas de vigilância e de assistência determinadas com o fim de prevenir a reincidência pelo prazo de dez, vinte ou trinta anos, dependendo da natureza da infração cometida, e podendo impor-se o controle, inclusive, por prazo indefinido, no caso de condenação perpétua.
} 
condenação à pena de prisão superior a dez anos sem sursis ou em relação as quais o sursis foi integralmente revogado; as decisões decorrentes de condenação à pena de prisão não superior a dez anos sem sursis em relação as quais o tribunal determinou a anotação e as decisões decorrentes de un suivi socio-judiciarie ou a pena de interdição para o exercício de atividade profissional ou beneficente que demande contato habitual com menores.

Também, é possível requerer ao juiz, no momento da condenação ou posteriormente, que a condenação não seja inscrita no boletim três, permanecendo inscrita nos boletins um e dois. O boletim três é expedido somente mediante requerimento do próprio interessado.

Nos casos das chamadas "pessoas morais", existem apenas dois boletins. O boletim número um apresenta a totalidade das informações registradas e é reservado às autoridades judiciárias. Do boletim número dois consta conteúdo parecido com aquele descrito para as pessoas físicas, entretanto nele não figura a condenação em que foi imposta somente pena de multa inferior a 200 mil francos. A quantidade de autoridades administrativas as quais têm permissão de obtê-lo é reduzida. Para as "pessoas morais" não há previsão da expedição de documento que se assemelhe ao boletim número três, das pessoas físicas.

A análise do registro criminal francês, denominado casier judiciare, possibilita verificar que ele se divide entre os dados das pessoas físicas e morais, reunindo em relação a cada grupo, basicamente, informações criminais além de outras de natureza diversa.

Os dados desse sistema são exteriorizados por boletins cujo conteúdo será restrito ou ampliado a partir do status do solicitante. O registro francês contém normas que flexibilizam o automatismo das inscrições, ao permitir que o juiz dispense a anotação de determinadas condenações no registro ou, ainda, admita que ela não seja transcrita em determinado boletim. Sob outro aspecto, cabe salientar que o sistema é permeável ao tempo, porque depois de certo período as informações deixam de ser transcritas nos boletins.

\subsection{O registro criminal na Espanha}

Na Espanha os antecedentes penais são tratados como conseqüências jurídicas do delito e inscritos no Registro Central de Penados y Rebeldes, ${ }^{202}$ centralizado no Ministério 
da Justiça, embora os juízes de instrução dos locais onde correram os processos a partir do seu trânsito em julgado também estejam obrigados a manter o livro de Registro de Penados como dispõe o artigo 254 da Ley de Enjuiciamento Criminal. As folhas desse livro são numeradas, carimbadas e rubricadas e delas são extraídos os certificados comprobatórios dos antecedentes.

A finalidade do Registro Central de Penados y Rebeldes é recolher as informações penais produzidas pelos tribunais e ministrar informações úteis à administração da justiça a pedido dos mesmos tribunais, juízes, organismos públicos e interessados privados. ${ }^{203}$

Os antecedentes penais exercem função múltipla, porque são levados em conta nas posteriores aplicações da lei penal ou processual. Eles servem para a comprovação da reincidência, impedimento da suspensão da execução da pena ou da substituição das penas privativas de liberdade e da concessão da liberdade provisória e, ainda, para a caracterização da habitualidade criminosa ou estado de reo habitual conforme dispõe o artigo 94 do Código Penal espanhol. Além disso, os antecedentes criminais poderão servir para controlar o ingresso de pessoas no serviço público, orientar a expedição de passaporte e licença para o porte de armas, bem como o conhecimento do seu conteúdo poderá ser condição fixada pelo particular antes de conceder emprego ao candidato. ${ }^{204}$

A Constituição espanhola orientou o cumprimento da pena para a busca da reinserção social, ${ }^{205}$ e a reforma penal de 1983 deveria alinhar o tema antecedentes penais ante o texto constitucional em razão da dificuldade da reinserção do condenado. Entretanto parece que a lei penal não aproveitou essa oportunidade, porque o dispositivo do Código Penal de 1983 que trata do tema (artigo 136, número 4) manteve o regramento anterior. ${ }^{206}$

O Código Penal vigente na Espanha, tal qual o anterior, dispôs que as inscrições, feitas a partir das condenações comunicadas pelo juiz ou tribunal ao Registro Central de Penados y Rebeldes, não são públicas e delas somente serão emitidos certificados dentro

1848, que criou o Registro General de Penados. Na Espanha, até meados de 1980, foram editados vários textos legislativos para tratar do Registro Central de Penados y Rebeldes (BUENO ARÚS, Francisco, op. cit., p. 15).

${ }^{203}$ GROSSO GALVAN, Manuel, op. cit., p. 116.

${ }^{204}$ MIR PUIG, Santiago. Derecho penal: parte general. 4. ed. Barcelona: PPU, 1996. p. 778.

$205 \mathrm{O}$ artigo 25, número 2, da Constituição espanhola, de 1978, prevê que: "Las penas privativas de libertad y las medidas de seguridad estarán orientadas hacia la reeducación y reinserción social y no podrán consistir en trabajos forzados. El condenado a pena de prisión que estuviere cumpliendo la misma gozará de los derechos fundamentales de este Capítulo, a excepción de los que se vean expresamente limitados por el contenido del fallo condenatorio, el sentido de la pena y la ley penitenciaria. En todo caso, tendrá derecho a un trabajo remunerado y a los beneficios correspondientes de la Seguridad Social, así como al acceso a la cultura y al desarrollo integral de su personalidad."

${ }^{206}$ MIR PUIG, Santiago, op. cit., p. 779. 
das normas estabelecidas e nas hipóteses previstas em lei. ${ }^{207} \mathrm{O}$ texto permite informar o juiz ou o tribunal sobre as inscrições canceladas ou não, devendo constar expressamente do certificado que ele é apresentado mediante determinação judicial.

O cancelamento dos antecedentes delitivos, outrora denominado na Espanha de rehabilitación, é o meio redutor dos efeitos negativos do registro de antecedentes criminais.

A legislação básica que trata do cancelamento de antecedentes penais na Espanha consiste em:

a) artigo 118 do Código Penal de 1973 (alterado pela Lei Orgânica 8/1992, de 25 de junho);

b) artigos 82, 85, 136 e 137, todos do Código Penal de 1995 (alterados os três primeiros pela Lei Orgânica 16/2003, de 25 de novembro);

c) Real Decreto 2012/1983, de 28 de julho, sobre cancelamento de antecedentes penais.

Nesse país, o Registro Central de Penados y Rebeldes integra o Ministério da Justiça e está regulado pelo Real Decreto 1475/2004, de 18 de junho.

É interessante assinalar também que o artigo 255 da Ley de Enjuiciamento Criminal prevê que os juízes de instrução deverão manter o Registro de procesados en rebeldía, à semelhança do Registro Central de Penados y Rebeldes, para controlar "[...] todas las causas cuyos procesados hayan sido declarados rebeldes".

A suspensão da execução da pena privativa de liberdade inferior a dois anos é regulada pelo artigo 81 do Código Penal espanhol que exige tenha o acusado praticado crime pela primeira vez para gozar o benefício. Não se levará em consideração, entretanto, as condenações por crimes culposos, "[...] ni los antecedentes penales que hayan sido cancelados, o debieran serlo".

Segundo disposições revogadas do Código Penal espanhol, a pena privativa de liberdade, cuja execução fosse suspensa por determinação do juiz ou de tribunal, era inscrita em uma secção especial do Registro Central de Penados. Referida secção funcionava em separado ("cuarto oscuro"), e os dados nela compilados somente eram franqueados aos juízes ou tribunais (artigo 82, segunda parte). Quando a suspensão fosse revogada, seria determinada a inscrição da pena no Registro Central de Penados y Rebeldes

${ }^{207}$ Cf., inclusive, GROSSO GALVAN, Manuel, op. cit., p. 115-118. 
(artigo 85, número 1), mas se o acusado não delinqüisse e cumprisse as regras de conduta fixadas, o juiz ou tribunal ordenaria "la cancelación de la inscripción hecha en la Sección especial del Registro Central de Penados y Rebeldes", e o antecedente penal produzido não acarretaria efeito algum (artigo 85, número 2). Entretanto, a Espanha retrocedeu nesse ponto, pois a Lei Orgânica 15/2003, de 25 de novembro, reformadora do Código Penal espanhol, suprimiu referências mencionadas aos artigos 82 e 85, impondo sejam comunicadas ao Registro Central de Penados y Rebeldes as sentenças definitivas, suspensas ou não. ${ }^{208}$

O Código Penal espanhol determina que sejam desprezadas para a caracterização dos antecedentes criminais as condenações quando satisfeitas as condições para o seu cancelamento, embora essa providência não tenha sido determinada pelo juiz ou tribunal (artigo 136, número 5), situação semelhante àquela tratada pelo artigo 81 do mesmo Codex a qual prevê a suspensão da pena. Nessa hipótese, se o órgão judicial considerar a presença das circunstâncias que determinariam a concessão do cancelamento do registro ordenará seu cancelamento e não levará em conta tais antecedentes, ocorrência impropriamente denominada prescripción de la reincidencia. ${ }^{209}$

\subsection{Referências gerais ao registro criminal em outros países}

Inicialmente, ressalta-se que a Grã-Bretanha e os Estados Unidos não dispõem do registro criminal nos moldes estruturados a partir daquilo que fora proposto por Bonneville de Marsangy. Os cadastros mantidos nesses países se encontram sob a responsabilidade dos serviços policiais e servem, especialmente, para prevenir e detectar fatos criminosos. Neles se inscrevem, automaticamente, apenas os crimes mais graves, enquanto a anotação daqueles que não têm essa natureza depende dos critérios adotados pela organização policial gerenciadora do sistema. A Grã-Bretanha e os Estados Unidos, portanto, possuem um registro policial, tanto que o fornecimento das informações aos órgãos judiciais não é sua finalidade básica. ${ }^{210}$

As características mais evidentes do sistema de registro criminal dos diversos países da Europa, relacionadas aos aspectos da organização e do funcionamento e fornecidas por meio da análise comparativa de suas legislações, são a autonomia, o

\footnotetext{
${ }^{208}$ BUENO ARÚS, Francisco, op. cit., p. 34-35 e 89-90.

${ }^{209}$ MIR PUIG, Santiago, op. cit., p. 780.

${ }^{210}$ COSTA, António Manuel de Almeida, op. cit., p. 157.
} 
automatismo e a centralização.

A adoção do sistema de Bonneville de Marsangy pela maior parte dos países da Europa continental, no final do século XIX, permitiu a criação do registro criminal autônomo e capaz de atender a justiça criminal. Disso resultou uma característica que persiste até hoje, que é a "autonomia intencional do registro criminal". Nota-se que, embora organizado no interior dos serviços policiais em países como a Áustria, Noruega, Suíça e Chipre, o registro criminal europeu dispõe de um serviço próprio, independente e autônomo, mas por disposição legal pode auxiliar as investigações realizadas pela polícia. Mantendo a autonomia, o serviço algumas vezes poderá estar vinculado ao Ministério da Justiça, como ocorre na Bélgica, Grécia e Turquia. É freqüente atribuir a direção do departamento a um magistrado do Ministério Público ou a outro funcionário de escalão superior. É importante que a autoridade designada para gerenciar o sistema tenha elevado discernimento para exercer os poderes discricionários que lhe são atribuídos, principalmente para encaminhar os casos duvidosos e as questões relacionadas ao acesso. ${ }^{211}$

O automatismo, isto é, a inscrição da informação independentemente de determinação, é regra no continente europeu, à exceção da Turquia, país onde o registro somente é alimentado depois de decisão autônoma do próprio juiz da condenação. A centralização, por sua vez, é acatada pela legislação de diversos países. Ela permite a existência do cadastro único em detrimento do regional, abandonando-se a formação dos ficheiros locais baseados na naturalidade ou no domicílio, apregoada originariamente por Bonneville de Marsangy, para evitar a perda total do acervo em casos de acidentes, como ocorreu no incêndio que destruiu a Prefeitura de Paris em 1871. ${ }^{212}$

Outros dois assuntos devem ser mencionados neste ponto do estudo, concentrado no registro criminal dos diversos países da Europa. São eles o emprego da informática como meio auxiliar para as anotações e acessos ao registro criminal e o registro das infrações penais praticadas por menores.

Até meados de 1981, somente Luxemburgo, Itália e a antiga Alemanha Federal dispunham de cadastros computadorizados, embora houvesse estudos e projetos para a introdução da informática.

Apesar de não ser objeto deste estudo, é conveniente indicar que o registro dos menores envolvidos em infrações deve ser apartado do registro criminal, importando,

${ }_{211}$ COSTA, António Manuel de Almeida, p. 159-160.

${ }^{212}$ Id., ibid., p. 160-161. 
sobretudo o sigilo dos seus dados para atender a peculiar idéia da reintegração social, porque a personalidade do adolescente é favorável à sua reinserção social. ${ }^{213}$

Os artigos $23^{\circ}$ e $24^{\circ}$, ambos do Decreto-Lei $n^{\circ} 39 / 83$, estabeleceram em Portugal o registro especial de menores. Conquanto esteja inserido no Centro de Identificação Civil e Criminal (CICC) e funcione nos moldes do registro criminal, o registro especial de menores é um arquivo próprio cujo conteúdo e acesso são peculiares. Há disposição legal que permite que o registro de menores esteja subordinado ao regime geral do registro criminal nos casos em que o menor contar com mais de dezesseis anos e cometer crime doloso ao qual corresponda pena superior a dois anos de prisão ou tiver sido objeto de pena relativamente indeterminada. ${ }^{214}$

Na Espanha, anotam-se fora do Registro Central de Penados y Rebeldes as decisões definitivas impostas a menores de 18 anos submetidos a "medidas correcionales o educativas, en virtud de la LO 5/2000, de 12 de enero, BOE del 13, por remisión del artículo 19 del CP [...] el cual sólo podrá ser utilizado por los Jueces de Menores y por el Ministerio Fiscal (disposición adicional $3^{a}$ de la LO 5/2000 y RD 232/2002, de 1 de marzo)."

Retomando a análise do conteúdo do registro criminal, cabe esclarecer que sua função é delimitar as informações que serão inseridas nos cadastros. Em regra, a lei vigente em diversas localidades da Europa reduz a discussão a respeito do assunto, porque dispõe que a transcrição das decisões será automática. Entretanto a divulgação das informações inseridas nos certificados poderá ser limitada em razão de motivos de política criminal. As inscrições feitas no registro criminal são concisas e, nesse aspecto, divergem do denominado dossier pessoal ou de personalidade. Nesse apanhado são reunidas outras anotações além das referências às condenações, tais como dados pessoais relativos aos aspectos psicológico, social, médico, familiar, profissional e comportamental, bem como compiladas as referências produzidas pelos profissionais dos estabelecimentos penais onde a pessoa cumpriu pena e as conclusões de eventuais avaliações realizadas. ${ }^{215}$

No âmbito do direito comparado, em geral, o conteúdo do registro criminal não é restrito à matéria penal, porque dele constam anotações civis, comerciais, administrativas e policiais. $\mathrm{Na}$ esfera criminal, todas as sentenças judiciais definitivas são anotadas, tais como as decisões absolutórias e condenatórias, inclusive fazendo menção aos casos de

\footnotetext{
${ }^{213}$ COSTA, António Manuel de Almeida, p. 162.

${ }^{214}$ Id., ibid., p. 162 e 165.

${ }^{215}$ Id., ibid., p. 165.
} 
eventual concessão de suspensão da pena ou qualquer outro beneficio. Sedimentados na idéia de ampliar as condições para a ressocialização ou, simplesmente, de descongestionar os serviços, alguns países da Europa admitem algumas exceções ao registro das sentenças, dispensando a inserção de dados referentes aos menores ou pelo menos até certa idade, quando é mantido o registro especial dos menores. As decisões absolutórias relativas a determinados ou a todos delitos ou, ainda, relacionadas aos crimes de pequena gravidade, também são mantidas fora do registro criminal em determinados países europeus. ${ }^{216}$

No que concerne às decisões não-penais, países como a Alemanha, Bélgica e Grécia estabeleceram que sentenças relativas a interdições profissionais ou incapacidades, decretos de falência, perda de cidadania, expulsão do território nacional, limitação do uso de armas de fogo ou de condução de veículos motorizados devem constar do registro criminal, mesmo quando não decorrem de efeitos da pena ou de penas acessórias em razão da situação nelas determinada prolongar-se no tempo e ser indispensável conhecê-la sempre que necessário. Referida opção encontra respaldo na história da criação do registro criminal, embora ela não tenha sido adotada por países como Áustria, Chipre e Suíça que limitaram à esfera penal o conteúdo do registro. ${ }^{217}$

Discute-se a ampla construção do casier judiciare europeu em virtude da formação da União Européia. Por ora, esse é um tema controvertido, porque a maior parte dos Estados-Membros da União Européia se opõe à adoção dessa medida, seja por motivos de ordem técnica tendo em vista ser aparentemente difícil viabilizá-lo, seja por razões políticas sob a ótica da proteção da vida privada. A necessidade de existir formas de intercâmbio das informações criminais entre nações já foi sentida na Bélgica, especialmente quando Michel Fourniret, condenado na França por abusar de crianças, conseguiu um certificado de idoneidade moral e passou a trabalhar na cantina de uma escola. A tendência que parece orientar as autoridades dos vários países componentes da União Européia é de celebrar aproximação setorial, propondo que os atos ligados à pedofilia, a infrações à segurança viária e os casos de tráfico de drogas sejam conhecidos mutuamente. ${ }^{218}$

Entretanto, no âmbito do Conselho da Europa já existem convênios internacionais que obrigam os Estados subscritores fornecerem informações relativas aos antecedentes penais dos seus cidadãos, como forma de auxílio judicial internacional. Além desses, há um

\footnotetext{
${ }^{216}$ COSTA, António Manuel de Almeida, op. cit., p. 166-167.

${ }^{217}$ Id., ibid., p. 168-169.

${ }^{218}$ FERENCZI, Thomas. Faut-il un casier judiciare européen. Le Monde, Paris, 1 fév. 2005. Disponível em: $<$ http://www.france3europe.com/archive/2005/02/01/faut-il_un_casier_judiciare_europe.htm $>$. Acesso em: 11 jun. 2005.
} 
tratado de caráter regional que permite a comunicação dos antecedentes penais e informações sobre condenações judiciais por tráfico ilícito de entorpecentes e substâncias psicotrópicas assinado em 12 de outubro de 1984, em Lisboa, a partir da VI Conferência de Ministros da Justiça dos países hispano-luso-americanos. Referido tratado foi ratificado em 18 de abril de 1989 pela Espanha que, juntamente com os demais Estados que a ele aderiram, obriga-se a mais ampla assistência possível aos procedimentos referentes aos delitos acima mencionados, incluídas as comunicações sobre antecedentes penais. ${ }^{219}$

Antes de concluir essa abordagem, convém consignar que na vizinha Argentina, a Lei $\mathrm{n}^{\circ}$ 22.117, de 10 de dezembro de 1979, considerada complementar ao Código Penal, tratou do Registro Nacional de Reincidência, determinando seu funcionamento junto do Ministério da Justiça, como órgão centralizador das informações relacionadas aos processos penais de todas as jurisdições. ${ }^{220}$

Essa lei indica quais atos serão comunicados ao Registro, dentro do prazo de cinco dias a contar do trânsito em julgado da decisão, enquanto também obriga as unidades penitenciárias comunicar, dentro do mesmo prazo, o nome dos presos libertados, anteriormente condenados por delito, e daqueles que foram colocados sob liberdade condicional.

A lei dispõe que o registro criminal argentino será reservado, mas fornecerá informações:

a) aos juízes e tribunais de todo o país;

b) nas hipóteses determinadas pelas leis provinciais;

c) às autoridades policiais definidas na mencionada lei;

d) às autoridades estrangeiras, se houver previsão de intercâmbio das informações.

Essa legislação também encerra normas relacionadas à identificação e estatística criminal, porque prevê que as fichas datiloscópicas e outras comunicações que compõem o

${ }^{219}$ Francisco Bueno Arús (op. cit., p. 37-45) também menciona que a Espanha aderiu ao "Convenio de Aplicación del Acuerdo de Schengen de 14 de junio de 1985", relativo à gradual supressão dos controles das fronteiras comuns, que visa construir o "espaço judicial europeu", indispensável para a luta contra a delinqüência. Ele menciona que o documento internacional firmado pela Espanha prevê o "Sistema de Información de Schengen (SIS), que consiste en un procedimiento de consulta automatizado, en el cual se pueden introducir os datos relativos a comisión de hechos delictivos graves y a sus responsables, con las debidas garantías para la protección de los datos sensibles con arreglo al Convenio Europeo de 28 de enero de 1981 para la protección de las personas en lo referente al tratamiento automatizado de datos de carácter personal y la LO 15/1999, de 13 de deciembre (BOE del 14), que regula la protección de datos de carácter personal".

${ }^{220}$ ARGENTINA. L. 22117 - Registro Nacional de Reincidencia. Disponível em:

<http://consulex.com.ar/Legislacion/Leyes/L0022117.htm>. Acesso em: 3 jan. 2008. 
prontuário pessoal não poderão ser retiradas do Registro, devendo ser baixadas no caso de morte ou transcurso do prazo de cem anos contados da data do nascimento da pessoa, bem como determina a remessa de dados para confecção anual da estatística geral sobre a criminalidade e o funcionamento da justiça argentina.

É interessante assinalar, finalmente, que o artigo 11 dessa legislação atribuiu aos "representantes del ministerio público ante los tribunales con competencia en materia penal de todo el país, tendrán a su cargo vigilar el cumplimiento de la presente ley", determinando sejam sempre notificados antes de remessa do processo ao arquivo, enquanto dispõe a inadmissibilidade do arquivamento dos processos antes das comunicações ao órgão responsável pelo registro. 


\section{ACESSO AO REGISTRO}

\subsection{O acesso e a publicidade do registro criminal}

Acesso, em singelas palavras, é o meio que permite conhecer o conteúdo do registro criminal. Ele regula e traça o perfil desse instituto, porque modulará o conhecimento dos dados do registro. Os mecanismos de acesso ao registro também indicam o grau de preocupação estatal com a integração ao convívio social daquele que ostenta anotações criminais.

A publicidade é reflexo do acesso permitido ao registro criminal e encontra os seus limites na amplitude das informações nele inseridas e na possibilidade de o interessado tomar conhecimento dessas informações. A publicidade do registro dependerá do grau de tensionamento existente entre as propostas de defesa social formuladas em relação aos autores de crimes mediante emprego de métodos que utilizam a intimidação geral e a segregação para atingir suas finalidades em frente da idéia da ressocialização dessas pessoas, atingível pela redução dos efeitos estigmatizantes do instituto. Em determinados países a legislação difere o "acesso ao registro criminal" do "fornecimento de informações criminais", pois algumas nações consideram que o primeiro é a "possibilidade de consulta directa dos cadastros no próprio serviço oficial de registro" e que o segundo trata da mera “emissão de certificados”. A maior parte das leis, entretanto, dispõe que o acesso é exclusivo aos funcionários do registro e que os dados serão veiculados por meio dos certificados ou certidões. $^{221}$

O acesso de terceiros aos dados do registro em Portugal é regulado expressamente pela Lei 57/98, de 18 de Agosto. Conforme previsão do artigo $6^{\circ}$, o titular da informação, ou quem provar efetuar o pedido em seu nome ou no seu interesse, tem direito a tomar conhecimento dos dados, podendo, inclusive, se indevidamente registrados, exigir sua retificação, atualização ou supressão. $\mathrm{O}$ artigo $7^{\circ}$ do mesmo diploma legal contém nove alíneas que relacionam os órgãos e as autoridades que têm a permissão de aceder à informação, descrevendo a quais situações esse acesso é legítimo. Entre outras, cabe destacar:

a) magistrados judiciais e do Ministério Público, para fins de investigação criminal,

${ }^{221}$ COSTA, António Manuel de Almeida, op. cit., p. 192-193. 
instrução de processos criminais e execução de penas;

b) entidades legitimadas pela lei processual para prática de atos de inquérito ou instrução, ou ainda incumbidas de cooperar internacionalmente para prevenir e reprimir a criminalidade;

c) entidades que detenham competência legal para garantir a segurança interna, prevenir a sabotagem, o terrorismo, a espionagem e a prática de atos que por sua própria natureza possa alterar ou destruir o Estado de Direito constitucionalmente estabelecido. ${ }^{222}$

Outros países da Europa também facultam praticamente total acesso às informações extraídas do registro quando destinadas aos órgãos ligados à Justiça (juízes, tribunais, Ministério Público, polícia e serviços de estatística). Aos demais interessados, incluindo o próprio titular, o acesso é limitado à natureza, pública ou particular, da consulta pleiteada. A tendência européia é reduzir o acesso aos terceiros, exceto se o pedido interessar à pessoa ou for concedido mediante aval da autoridade superintendente dos registros. A situação é diferente quando o pedido é formulado por autoridade pública estrangeira, especialmente judiciária, para fins de instruir processos, hipótese em que, geralmente, o acesso concedido é idêntico ao permitido às autoridades nacionais. ${ }^{223}$

A faculdade de as entidades oficiais, membros das Comunidades Européias, acessarem aos dados do registro criminal mediante autorização do Ministro da Justiça é tratada em Portugal pela alínea "h" do artigo $7^{\circ}$ da Lei 57/98, de 18 de Agosto.

Esse dispositivo se refere, textualmente, à "Directiva 64/221, de 25 de Fevereiro de 1964”, do Conselho da Comunidade Econômica Européia, que tratou das medidas especiais relativas aos estrangeiros em matéria de deslocação e estada justificadas por razões de ordem, segurança e saúde públicas.

A “directiva” dispõe que a mera existência de condenações penais não pode, por si só, servir de fundamento à aplicação das medidas nela referidas e que o país de acolhimento pode, quando indispensável, solicitar ao Estado-Membro de origem e, eventualmente, a outros Estados-Membros informações sobre os antecedentes criminais do requerente. Entretanto a norma prevê que essa consulta não pode ter caráter sistemático e deve ser respondida até dois meses. ${ }^{224}$

${ }^{222}$ VEIGA, Catarina, op. cit., p. 148-149.

${ }^{223}$ COSTA, António Manuel de Almeida, op. cit., p. 195-196.

${ }^{224}$ As medidas reguladas pela mencionada diretiva são a recusa à emissão ou renovação de autorização de residência ou a decisão de expulsão do território, as quais poderão ser determinadas se constatadas doenças 
Nota-se, portanto, ser dúbia a orientação extraída da "Directiva 64/221, de 25 de Fevereiro de 1964", em relação aos antecedentes criminais, porque ela não autoriza nem proíbe sejam eles utilizados como critério para vedar a entrada ou impedir a permanência de estrangeiro nos países que integram a Comunidade Européia. Além disso, referida "directiva" trata o tema paralelamente ao regramento relativo às doenças contagiosas e às causas que geram risco à ordem e segurança públicas, sem afirmar ou negar que a pessoa que ostenta antecedentes criminais anotados no país de origem cause risco aos valores por último mencionados.

A legislação portuguesa reguladora da identificação e do registro criminal há pouco referida, portanto, seguiu a tendência européia antes mencionada, pois permitiu acesso ao registro criminal às "entidades oficiais de Estados membros das Comunidades Européias, nas mesmas condições das correspondentes entidades nacionais" mediante autorização do Ministro da Justiça lusitano. ${ }^{225}$

A requisição e o requerimento possibilitam o acesso ao registro criminal português. Previstos no Decreto-Lei $n^{\text {o }}$ 39/83, estão mantidos pela Lei 57/98, de 18 de Agosto, pois magistrados judiciais e do Ministério Público, entre outros órgãos e autoridades, poderão requisitar os certificados, enquanto para fins de emprego e demais finalidades particulares, esses documentos serão requeridos pelos interessados. Ao atender requisição, o responsável pelo registro português fornecerá à autoridade solicitante transcrição integral do registro, incluindo as decisões proferidas por tribunais estrangeiros e excetuando aquelas canceladas definitivamente. $\mathrm{O}$ conteúdo do certificado obtido mediante requerimento é menos amplo, não importando seu fim. Não se faculta às entidades públicas portuguesas, no exercício de

que causem risco à saúde pública (doenças que obriguem à quarentena; tuberculose do aparelho respiratório ativa ou de tendência evolutiva; sífilis; outras doenças infecciosas ou parasitárias contagiosas que sejam, igualmente, objeto, no país de acolhimento, de disposições para proteção dos nacionais) e doenças e afecções que também causem riscos à ordem pública ou à segurança pública (toxicomania; alterações psicomentais grosseiras; estados manifestos de psicose de agitação, psicose delirante ou alucinatória e psicose confusional) [PORTUGAL. Directiva 64/221/CEE do Conselho, de 25 de Fevereiro de 1964. Disponível em: $<$ http://eurlex.europa.eu/LexUriServ/LexUriServ.do?uri=CELEX:31964L0221:PT:HTML>. Acesso em: 6 jan. 2008]. Em 18 de junho de 2008, o Parlamento Europeu aprovou "normas e procedimentos comuns para o regresso de nacionais de países terceiros em situação irregular. A directiva, conhecida como 'directiva do retorno' constitui uma primeira etapa no sentido de uma política de imigração européia e visa promover o regresso voluntário de imigrantes ilegais, estabelecendo simultaneamente normas mínimas comuns relativas ao seu tratamento". As providências, muito mais coercitivas do que voluntárias, contidas na recente normatização, que deverá ser complementada por outras duas directivas que tratarão dos empregadores de imigrantes ilegais e das condições de entrada e de residência de nacionais em países terceiros para efeito de emprego altamente qualificado, permitem aplicar medidas duras em relação aos imigrantes ilegais, tais como detenção de seis, prorrogável até doze meses, respeitada a legislação local, entretanto, não tratou da consulta ao cadastro criminal para dificultar ou impedir a imigração (PORTUGAL. Directiva do Retorno. Disponível em: $<$ http://www.europarl.europa.eu/news/public/focus_page/018-32673-177-06-26-90220080625FCS32672-25062008-2008/defaut_pt.htm >. Acesso em: 21 out. 2008).

${ }^{225}$ VEIGA, Catarina, op. cit., p. 149. 
funções administrativas, acesso direto às informações dos cadastros. Nesse caso, o órgão público poderá obter a informação, indiretamente, por intermédio do particular candidato à vaga no serviço público, por exemplo, que lhe transmitirá os dados. ${ }^{226}$

$\mathrm{Na}$ Espanha, um dos princípios gerais acerca do Registro Central de Penados y Rebeldes é a chamada "publicidade restritiva", resultado da não-publicidade das inscrições de antecedentes criminais firmada a partir de disposição inserida no Código Penal desse país, que permite entender que não é devido comunicar dados do registro criminal a outras pessoas que não aquelas indicadas restritivamente por tratados internacionais e leis internas. $^{227}$

O acesso ao registro criminal controla a publicização das informações nele guardadas. As normas reguladoras do acesso devem ser claras e minuciosas. Elas também devem ser precisas para evitar intromissões excessivas e franquear, quando necessário, o conhecimento dos dados do registro às autoridades e aos órgãos relacionados à aplicação da lei penal, em seu sentido amplo, ou aos particulares legitimados em conhecê-los.

O registro criminal manterá sua utilidade e jovialidade se conseguir criar normas relativas ao acesso que, em linhas gerais, preservem o instituto da acessibilidade desmedida, mas não restrinjam, sem motivos justificáveis, a exteriorização necessária do seu conteúdo. A estrutura do registro deve permitir a publicidade dos dados com a finalidade de atender o interesse público e particular justificados, sem ofender a privacidade e ampliar, de forma desnecessária, o risco à liberdade das pessoas.

\subsection{Formas de acesso}

Geralmente, a forma usual e freqüente de acesso ao conteúdo das informações inscritas no registro criminal é indireta, ou seja, as informações são conhecidas pelo interessado por meio da expedição de certidões e certificados, sem possibilitar manuseio ou contato direto dos documentos ou dados componentes do registro. ${ }^{228}$

Outra forma possível reside no acesso direto aos mencionados dados, freqüentemente vedado pela legislação. $\mathrm{O}$ aspecto desfavorável do acesso direto consiste

${ }^{226}$ Cf. COSTA, António Manuel de Almeida, op. cit., p. 198-199 e VEIGA, Catarina, op. cit., p. 149-151.

${ }^{227}$ BUENO ARÚS, Francisco, op. cit., p. 74.

${ }^{228} \mathrm{Na}$ Espanha, em meados de 1914, havia determinação legal que estabelecia interessante regra que fixava em três meses, a contar da data da sua expedição, o prazo de validade da certificação para fins particulares emitida pelo Registro Central de Penados y Rebeldes. Id., ibid., p. 16. 
em permitir o conhecimento de decisões canceladas enquanto o ponto favorável, em possibilitar o acesso rápido e seguro ao registro. $\mathrm{O}$ fundado receio de que o administrador do sistema não forneça informações fidedignas sobre os dados nele reunidos é fundamento usado para regular, expressamente, as situações em que são cabíveis acessar diretamente o conteúdo do registro. Estabelecer sanções severas ao agente que violar o segredo contido na informação criminal ou negligenciar intencionalmente informações e condicionar o excepcional acesso direto à prévia notificação do titular do registro e, dentro do possível, fazê-lo perante o interessado, seu representante legal ou advogado são mecanismos que proporcionam segurança e transparência ao sistema. ${ }^{229}$

Constitui condição indispensável à obtenção de informes relativos ao registro criminal a perfeita identificação da pessoa em relação a qual se buscam os dados. A partir da aquisição dos dados de identificação pessoal, os agentes públicos e os particulares, normalmente, deverão dirigir-se ao órgão encarregado de fornecer as informações reunidas no registro e preencher formulário impresso por meio do qual será manifestado interesse em conhecer referidas informações. ${ }^{230}$

$\mathrm{Na}$ Espanha, os pedidos oficiais para obterem-se informações acerca de antecedentes criminais contêm referências do juiz ou tribunal requisitantes e dados do sujeito cujas informações são necessárias e em relação ao qual se informam o nome completo, idade, filiação, nome do cônjuge, lugar do nascimento, profisssão e se é alfabetizado. A petição, encaminhada ao Chefe do Registro Central de Penados y Rebeldes, será respondida no verso do formulário, providência simples, mas redutora do risco de erros e trocas de informes. Existindo anotações, será informado o número do processo, o crime que motivou o antecedente, a data da sentença e demais dados relativos à condenação. ${ }^{231}$

Nesse país, a atual redação do artigo 137 , número 4, do Código Penal ${ }^{232}$ prevê que as inscrições de antecedentes penais reunidas no Registro Central de Penados y Rebeldes não serão públicas. Essa norma fixa também que, enquanto vigentes as anotações, os

\footnotetext{
${ }^{229}$ COSTA, António Manuel de Almeida, op. cit., p. 355-356.

${ }^{230}$ Em Portugal é previsto que "ao registo de cada cidadão identificado criminalmente é atribuído um número seqüencial ao qual se reporta toda a informação criminal existente a seu respeito", conforme dispõe o artigo $4^{\circ}$, do Decreto-Lei 381/98, de 27 de novembro (Diário..., cit., p. 6576). No Estado de São Paulo, os dados da pessoa submetida à identificação criminal, que deverão ser inseridos no sistema de informações criminais, são cadastrados pelo Instituto de Identificação Ricardo Gumbleton Daunt (IIRGD) a partir do nome e demais informações relativas à qualificação (filiação, local e data do nascimento), acrescidos do número do registro geral estadual daqueles que já possuem referido número. Caso a pessoa não possuir número de identificação civil emitida em São Paulo, conhecido como "RG", o próprio sistema lhe atribuirá um número especial e particular para completar o cadastramento.

${ }^{231}$ GROSSO GALVAN, Manuel, op. cit., p 157-158.

${ }^{232}$ Ley Orgánica 10/1995, de 23 de noviembre.
} 
respectivos certificados somente serão emitidos com as limitações e garantias previstas nas normas específicas e nos casos estabelecidos por lei, explicitando o próprio Código Penal espanhol que, em todo caso, serão liberadas as solicitações feitas por juízes e tribunais relativas a todas inscrições existentes, inclusive canceladas, mas nessa hipótese será referido o cancelamento.

Antes da vigência desse dispositivo no Código Penal espanhol, argumentava-se que nesse país era preciso fazer desaparecer o acesso generalizado dos particulares ao registro. Criticava-se, à época, a amplitude do acesso particular aos dados do registro e a prática disseminada de as empresas privadas exigirem dos candidatos aos postos de trabalho certificado de penales en limpio com a mesma tranqüilidade que lhes impunham realizar testes psicológicos. Essa obstinação em consultar o registro foi iniciada pela própria administração e gerou infindável lista de previsões da indispensabilidade de o particular ofertar informações extraídas, normalmente, a seu pedido, do registro criminal para apresentá-las aos diversos órgãos públicos e aos serviços prestados pela administração com fins diversos, tais como concorrer aos postos de trabalho abertos pela própria administração, ingressar nas Forças Armadas, obter licença para uso doméstico de arma e expedição de passaportes, realizar contrato com o poder público e outros. ${ }^{233}$

Por trás da disseminação da idéia da obrigatoriedade da apresentação da certidão de antecedentes em face de situações diversas, algumas pouco explicadas, nota-se o interesse econômico no recolhimento das taxas cobradas para a expedição dos mencionados documentos e a finalidade de desonerar a própria administração de adquiri-los diretamente do órgão responsável pela sua expedição. Além disso, é inegável o efeito psicológico que resultava do ato de obter certidão para juntá-la aos requerimentos e solicitações enviados à Administração Pública. Nessa oportunidade, toda pessoa, mesmo aquela que não ostentasse condenação, ficaria submissa ao poder da prestação da informação pública sobre seu passado. Em relação ao condenado, especialmente, esse momento serviria para lembrá-lo de que o Estado não esqueceu o crime que ele praticou e foi registrado em seu nome, em franco abandono ao ideal da sua ressocialização. ${ }^{234}$

$\mathrm{Na}$ Espanha, o próprio interessado ou terceira pessoa podia solicitar informes ao registro, mas o terceiro somente os receberia caso fossem negativos. Se existisse registro, a certidão seria entregue apenas ao próprio interessado ou quem por ele fosse autorizado. Essa sistemática facultava a qualquer um acesso aos antecedentes penais de outrem, com a

${ }^{233}$ GROSSO GALVAN, Manuel, op. cit., p. 159-161.

${ }^{234}$ Id., ibid., p. 162-164. 
única limitação de não obter o documento comprobatório da sua existência, pois esse procedimento permitia deduzir, facilmente, que em nome daquela pessoa havia registro de antecedentes embora sem possibilitar conhecer sua natureza. ${ }^{235}$

Ainda levando em consideração referências feitas pela legislação espanhola em relação à emissão dos certificados, por certo período nesse país havia regra limitadora da publicidade concernente a delitos culposos cometidos com veículo automotor. Nesse período, era exigida a apresentação de certificado do Registro Central de Penados y Rebeldes para instruir pedido de obtenção de autorização para condução de veículo automotor, mas somente era informada anotação relativa a delito cometido em razão do uso e circulação de veículos a motor, conforme previsão da Ley penal del Automóvil, de 9 de mayo de 1950, y la Ley 122/1962, de 24 de diciembre. Entretanto, referida normatização perdeu o objeto a partir da dispensa da apresentação do certificado criminal para obtenção da permissão para dirigir. ${ }^{236}$

A tendência em relação ao acesso aos dados do registro criminal é tornar o certificado ou a certidão como veículos únicos para a comunicação dos elementos inseridos nos ficheiros. ${ }^{237} \mathrm{~A}$ informática aplicada aos arquivos do registro criminal facilita o acesso, permitindo seja feito à distância.

São exercidas várias influências sobre a organização do registro criminal, mas uma das mais relevantes e que merece atenção é aquela realizada pela Administração da Justiça, pois é nesse âmbito que será definido o que se busca e pretende do sistema classificatório utilizado pelo registro. ${ }^{238}$

Sob esse aspecto, é interessante observar que, no Estado de São Paulo, as Normas de Serviço da Corregedoria-Geral da Justiça regulam a emissão das certidões judiciais contendo informações criminais. ${ }^{239}$ Referidas normas são dinâmicas em razão da atualização constante que sofrem dos provimentos editados pela Corregedoria-Geral da Justiça os quais, recentemente, demonstram tendência de restringir a publicidade dos dados do registro, inclusive determinando que as anotações referentes à distribuição de cartas

\footnotetext{
${ }^{235}$ GROSSO GALVAN, Manuel, op. cit., p. 159 e 166.

${ }^{236}$ BUENO ARÚS, Francisco, op. cit., p. 18 e 32.

${ }^{237}$ COSTA, António Manuel de Almeida, op. cit., p. 193.

${ }^{238}$ GROSSO GALVAN, Manuel, op. cit., p. 126.

239 PROVIMENTO N ${ }^{\circ}$ 50, de 1989. Artigo 54. Publicações Eletrônicas Associação Paulista do Ministério Público. São Paulo: APMP, 2004-2006. 1 CD-ROM. Produzido por Eduardo Roberto Alcântara Del-Campo e Marinilce Araújo Soria.
} 
precatórias não constem, em regra, das certidões expedidas pela Justiça. ${ }^{240}$

Citada tendência, entretanto, não se aplica às requisições judiciais, requerimentos feitos pela própria pessoa interessada ou seu representante legal, pois em resposta a essa modalidade de consulta serão fornecidas informações amplas. ${ }^{241}$

Essa inclinação para restringir a publicidade dos dados do registro a terceiros pode ser constatada pela análise do conteúdo do item 54 dessa normatização que, em linhas gerais, orienta os trabalhos administrativos realizados pelos servidores da Justiça no Estado de São Paulo ao fornecer informações reunidas nos registros judiciários.

Mencionada norma, embora sem força de lei, prevê que as certidões de antecedentes e os relatórios de pesquisa eletrônica serão expedidos com a anotação "nada consta" nos seguintes casos:

a) inquéritos arquivados;

b) indiciados não denunciados;

c) não-recebimento de denúncia ou queixa-crime;

d) declaração da extinção de punibilidade;

e) trancamento da ação penal;

f) absolvição;

g) impronúncia;

h) pena privativa de liberdade cumprida, julgada extinta, ou que tenha sua execução suspensa;

i) condenação à pena de multa isoladamente;

j) condenação à pena restritiva de direitos, não convertida em privativa de liberdade;

1) reabilitação não revogada;

m) pedido de explicação em juízo, interpelação e justificação;

\footnotetext{
240 “Artigo 54.2. Das certidões expedidas pelos Distribuidores não constarão as cartas precatórias, salvo se houver autorização expressa do Juiz Corregedor Permanente do respectivo ofício ou seção, mantendo-se fichário para os demais fins" (Normas de Serviço da Corregedoria-Geral da Justiça do Estado de São Paulo. Publicações Eletrônicas Associação Paulista do Ministério Público. São Paulo: APMP, 2004-2006. 1 CDROM. Produzido por Eduardo Roberto Alcântara Del-Campo e Marinilce Araújo Soria).

241 “Artigo 54.4. O disposto nos itens anteriores não se aplica às requisições judiciais, requerimento do pesquisado ou seu representante legal" (Normas de Serviço da Corregedoria-Geral da Justiça do Estado de São Paulo..., cit.).
} 
n) imposição de medida de segurança consistente em tratamento ambulatorial;

o) suspensão do processo prevista no artigo 89 da Lei n 9.099, de 1995;

p) feitos relativos aos Juizados Especiais Criminais em que não haja aplicação de pena privativa de liberdade.

Tratar, convenientemente, a questão do acesso ao conteúdo do registro é providência que deve ser incorporada pela legislação nacional, possibilitando que ela trace normas gerais acerca do registro criminal, pois exterioriza a preocupação estatal com valores essenciais para o convívio humano, como a privacidade, a liberdade e a segurança.

$\mathrm{O}$ acesso às informações reunidas pelo registro criminal deve assegurar aos órgãos encarregados da persecução penal, em sentido amplo, e aos particulares, dentro dos limites estabelecidos, conhecerem as informações contidas no registro sem expor, desnecessariamente, a privacidade e ampliar riscos à liberdade da pessoa.

\subsection{Acesso para fins investigativos e processuais}

As diretrizes que regem o acesso ao registro criminal para fins de investigação policial, instrução dos processos e execução penal são diversas daquelas relativas ao acesso para finalidades particulares e administrativas, porque naqueles domínios é imprescindível ofertar informações completas em relação às pessoas alcançadas pela investigação, pelo processo de conhecimento ou de execução da pena. ${ }^{242}$

Esses dados podem ser importantes, no campo policial, para investigar a autoria de determinado fato praticado mediante uso de técnica freqüentemente empregada pelo indivíduo investigado. Na esfera da justiça, pode servir para determinar a sanção a ser imposta em caso de condenação, enquanto na fase de execução, permitirá orientar o melhor tratamento aplicável ao recluso. Na fase investigativa, aliás, existem situações em que a apuração do crime é iniciada ao individualizar certo grupo ou pessoa encontrada entre aqueles que já cometeram semelhante prática infracional, usando idêntico modus operandi.

\footnotetext{
${ }^{242}$ Conforme Francisco Bissoli Filho (op. cit., p. 163), antecedentes e reincidência criminal são institutos cuja existência está fundamentada "na teoria da individualização da pena, à medida que, nas três instâncias em que a adaptação penal se realiza, os mesmos são considerados como fatores determinantes da pena. $\mathrm{Na}$ cominação o fundamento está na tipologia delinquencial, na definição de condutas e das circunstâncias judiciais, legais, gerais e especiais de aumento e ou diminuição de pena; na aplicação, está na adaptação da pena como circunstância judicial e agravante, como requisito da substituição e da suspensão condicional da pena; e na execução o fundamento reside na classificação prisional, na progressão de regimes, no livramento condicional, na saída temporária, na substituição de penas, nos procedimentos de seleção, etc.”
} 
No aspecto judicial, a demonstração da reincidência ou dos antecedentes criminais do acusado exige análise dos registros criminais, prática que foi um dos princípios objetivos traçados pelo instituto ao ser criado. ${ }^{243}$

A aferição da personalidade do acusado para fins de aplicação da pena exige conhecimento judicial de eventuais condenações anteriores. Porém, caso a condenação anterior tenha sido alcançada pela reabilitação ou pela anistia, informações relativas a tal situação sequer deveriam ser comunicadas, exceto na hipótese de a condenação reabilitada ainda permitir caracterização eventual da reincidência. Se houve entendimento judicial com trânsito em julgado ou determinação legal que resultou na concessão da reabilitação ou da anistia, parece dispensável que no futuro tais fatos sejam revolvidos pela justiça, se não se prestarem para caracterizar a reincidência ou antecedentes penais desabonadores. ${ }^{244}$

Uma das principais questões que se coloca nesse ponto do estudo é a desconfiança exteriorizada por juízes e tribunais em relação às pessoas condenadas. $\mathrm{Na}$ prática, relativamente aos reincidentes, o in dubio pro reo transforma-se em in dubio contra reum, servindo o conhecimento da condenação anterior para agravar o rigor da sanção imposta sem qualquer preocupação com a reintegração social do condenado. Nesses casos, a publicidade e oralidade do processo expõem ainda mais o acusado que ostenta antecedentes criminais. Essa exposição é exacerbada se o resultado do processo é absolutório, porque a pessoa processada suporta o sacrifício da exibição da sua intimidade sem existirem meios para condená-lo. Esse quadro mostra franca contradição, pois de um lado está a necessidade de dotar o juiz das informações relativas ao passado do acusado, enquanto do outro se posicionam a lei e a finalidade de manter sob a reserva possível os dados do registro criminal. $^{245}$

Os antecedentes penais do acusado, reunidos no registro criminal, poderão ser consultados para obtenção de informações acerca de sua identidade e personalidade, traços apreciados, especialmente, no momento do julgamento, tanto que já foi admitido ser essa a primeira utilidade do registro. Apesar de ser contraditório dizer que os antecedentes são dados que servem para adiantar juízo sobre uma pessoa levando em consideração ações passadas, tais informes poderão ser úteis aos peritos que deverão analisar se o acusado é, por exemplo, um psicopata. A existência de condenações anteriores servirá como fonte de

\footnotetext{
${ }^{243}$ COSTA, António Manuel de Almeida, op. cit., p. 321-324.

${ }^{244}$ No Brasil, vige a regra da permanência da condenação reabilitada no registro criminal para fins de informar ao juiz criminal, nos termos do artigo 748 do Código de Processo Penal. $\mathrm{O}$ artigo 71 , $\S 2^{\circ}$, do Código Penal Militar determina que não se considere, para efeito da reincidência, os crimes anistiados.

${ }^{245}$ COSTA, António Manuel de Almeida, op. cit., p. 325-327.
} 
informação a ser valorada por esses profissionais. Nesse caso, o acesso diferencia-se da consulta privada às informações do registro e, na Espanha, citada providência é possível, porque o perito funciona como parte no processo, diversamente dos particulares. $^{246}$

Ainda no que concerne ao emprego do registro criminal para fins processuais penais, o Código de Processo Penal brasileiro indiretamente permite ao juiz buscar informações nele contidas em situações definidas, sem relação direta da verificação dos antecedentes do investigado, acusado ou condenado, mas para aferir a idoneidade daqueles que colaborarão com a Justiça exercendo funções de depositário das coisas cuja restituição se discute ${ }^{247}$ jurado, $^{248}$ perito não oficial ${ }^{249}$ e tradutor particular. ${ }^{250}$

Abordando outro aspecto do tema sob a ótica processual, nota-se que em relação ao condenado que goza de sursis a condenação será inscrita com nota de suspensão em registro secreto, mas mencionada informação deve ser fornecida ao juiz e aos órgãos que atuam na esfera criminal, porque o benefício poderá ser revogado e será considerado para fins da aferição dos antecedentes criminais e da reincidência. ${ }^{251} \mathrm{Se}$ impostas as sanções

${ }^{246}$ GROSSO GALVAN, Manuel, op. cit., p 31-32.

247 “Art. 120. A restituição, quando cabível, poderá ser ordenada pela autoridade policial ou juiz, mediante termo nos autos, desde que não exista dúvida quanto ao direito do reclamante.

$\S 1^{\circ}[\ldots]$

$\S 4^{\circ}$ Em caso de dúvida sobre quem seja o verdadeiro dono, o juiz remeterá as partes para o juízo cível, ordenando o depósito das coisas em mãos de depositário ou do próprio terceiro que as detinha, se for pessoa idônea.

$\S 5^{\circ}$ Tratando-se de coisas facilmente deterioráveis, serão avaliadas e levadas a leilão público, depositando-se o dinheiro apurado, ou entregues ao terceiro que as detinha, se este for pessoa idônea e assinar termo de responsabilidade."

248 “Art. 436. O serviço do júri é obrigatório. O alistamento compreenderá os cidadãos maiores de 18 (dezoito) anos de notória idoneidade.

$\S 1^{\circ}$ Nenhum cidadão poderá ser excluído dos trabalhos do júri ou deixar de ser alistado em razão de cor ou etnia, raça, credo, sexo, profisssão, classe social ou econômica, origem ou grau de instrução.

$\S 2^{\circ}$ A recusa injustificada ao serviço do júri acarretará multa no valor de 1 (um) a 10 (dez) salários mínimos, a critério do juiz, de acordo com a condição econômica do jurado.

$[\ldots]$

Art. 439. O exercício da função de jurado constituirá serviço público relevante, estabelecerá presunção de idoneidade moral e assegurará prisão especial, em caso de crime comum, até julgamento definitivo.”

Redação determinada pela Lei $\mathrm{n}^{\circ} 11.689$, de 9 de junho de 2008.

249 "Art. 159. O exame de corpo de delito e outras perícias serão realizados por perito oficial, portador de diploma de curso superior.

$\S 1^{\circ} \mathrm{Na}$ falta de perito oficial, o exame será realizado por 2 (duas) pessoas idôneas, portadoras de diploma de curso superior preferencialmente na área específica, dentre as que tiverem habilitação técnica relacionada com a natureza do exame."

Redação determinada ao caput e parágrafos pela Lei no 11.690 , de 9 de junho de 2008.

250 “Art. 236. Os documentos em língua estrangeira, sem prejuízo de sua juntada imediata, serão, se necessário, traduzidos por tradutor público, ou, na falta, por pessoa idônea nomeada pela autoridade."

${ }^{251}$ Conforme artigo 709, caput e parágrafo $2^{\circ}$, do Código de Processo Penal. O artigo 163 da Lei de Execução Penal atribui o caráter sigiloso ao registro e sua averbação feita no livro especial do juízo que couber a execução da pena. As Normas de Serviço da Corregedoria-Geral da Justiça do Estado de São Paulo (cit.) tratam do sursis, no item 54.1, do seguinte modo: "No caso de revogação de 'sursis', suspensão do processo prevista no artigo 89 da Lei 9099/95 e conversão da pena restritiva de direito em privativa de liberdade, a certidão voltará a ser positiva, após a comunicação do Juízo competente ao Distribuidor 
referidas no artigo 92, incisos I, II ou III, do Código Penal ou revogado o sursis, o seu registro não fruirá do caráter secreto conforme dispõe o artigo 709 , parágrafo $3^{\circ}$, do Código de Processo Penal.

É conveniente verificar, ainda, que a legislação penal brasileira impede que os crimes militares próprios e também políticos sirvam para forjar a reincidência. ${ }^{252}$ Contrário senso, as condenações decorrentes da prática de crime militar impróprio apurado pela Justiça Militar deveriam ser observadas para fins de reincidência e, portanto, comunicadas pelo órgão jurisdicional militar ao responsável pela inserção das informações no registro criminal. Esse procedimento permitiria o conhecimento da condenação anterior pela prática de crime militar impróprio e facultaria sua apreciação com a finalidade de forjar eventual reincidência, preservando o princípio constitucional da igualdade.

Cabe fazer ligeira pausa na exposição para, antes de focalizar o tópico seguinte que tratará o equilíbrio em relação ao acesso das informações criminais, tecer considerações acerca do registro do sursis, pois neste estudo se considera que o artigo 709 do Decreto-Lei n 3.689 (Código de Processo Penal), de 3 de outubro de 1941, não foi revogado, expressa ou tacitamente, pela Lei $n^{0} 7.210$, de 11 de julho de 1984, que instituiu a Lei de Execução Penal, especialmente pelo artigo 163 dessa lei, pelos motivos a seguir expostos.

A legislação mais recente não revogou a anterior e o confronto dos textos dos mencionados artigos permite entender que eles não são "conflitantes na letra ou no espírito", 253 mas ao contrário exigem interpretação conjugada e harmônica.

É possível verificar que o artigo 709 do Código de Processo Penal orienta o modo pelo qual o Instituto de Identificação, órgão responsável pela organização do registro criminal no Brasil, deverá anotar a sentença na qual o acusado foi beneficiado com sursis, a partir das comunicações feitas pelo juízo ou tribunal, obrigação cumprida supletivamente pelo primeiro, nos Estados da Federação em que não existirem Instituto de Identificação. Por sua vez, o artigo 163 da Lei de Execução Penal aponta como o juízo da execução deverá registrar a sentença na qual o acusado foi beneficiado com sursis, dirigindo-se ao próprio juízo da execução penal.

\footnotetext{
Criminal."

${ }^{252}$ Artigo 64, inciso II, do Código Penal.

${ }^{253}$ Julio Fabbrini Mirabete (Execução..., cit., p. 440) dizia que "a Lei de Execução Penal revogou todas as normas com ela conflitantes na letra ou no espírito. Nesses termos é impróprio dizer que ficou revogado todo o Livro IV do Código de Processo Penal, que trata da execução". A seguir, o autor mencionava em sua obra vários artigos do Código de Processo Penal cuja vigência não foi alterada pela Lei de Execução Penal, embora sem referir-se ao artigo 709 do Código de Processo Penal.
} 
Embora caput e parágrafo $1^{\circ}$ do artigo 163 da Lei de Execução Penal, praticamente, reproduzam o artigo 709, caput, do Código de Processo Penal, os destinatários de cada uma dessas normas são órgãos diferentes e incumbidos de funções diversas. O Código de Processo Penal volta-se ao Instituto de Identificação e a Lei de Execução Penal ao juízo da execução, organismos que exercem atividades distintas, pois ao Instituto de Identificação se atribui a emissão da folha de antecedentes e ao juízo da condenação a expedição de certidões, inclusive, sob a ressalva do disposto no artigo 202 da própria Lei de Execução Penal.

Para encerrar essa abordagem, cabe destacar que existem outros dois aspectos relacionados aos textos dos artigos 163 da Lei de Execução Penal e 709 do Código de Processo Penal, que merecem destaque para referendar a idéia da vigência do segundo e do cabimento da existência harmônica e integrada de ambos os dispositivos legais. O primeiro consiste no emprego adequado da expressão "sigilo" pela Lei de Execução Penal, ao contrário da palavra "segredo" usada pelo Código de Processo Penal, pois é o "sigilo" uma espécie de manto protetor do "segredo" a ser preservado. O segundo funda-se no cabimento e na adequação da faculdade de possuir o Ministério Público legitimidade para conhecer o registro do sursis, conforme previsto pelo parágrafo $2^{\circ}$ do artigo 163 da Lei de Execução Penal.

\subsection{Busca do equilíbrio e acesso}

Em linhas gerais, existem dois métodos objetivos que pretendem proporcionar justo equilíbrio entre o interesse dos órgãos da Justiça de conhecerem os antecedentes criminais de uma pessoa para fins judiciais e a necessidade de evitar que a publicização dessas informações exponha, indevidamente, a privacidade do acusado.

O primeiro deles refere-se ao campo de atuação do direito processual penal e exige mudança do modo ou momento que o juiz toma conhecimento da vida criminal pregressa do acusado, alteração que pode ser alcançada pela limitação da divulgação das condenações anteriores até a audiência de julgamento. $\mathrm{O}$ segundo consiste na instituição de "bipartição do processo, à semelhança do direito anglo-americano, em duas fases distintas e grosso modo estanques entre si (césure)", procedimento que permite averiguar na fase inicial a imputação do fato à pessoa acusada e, na seguinte, corolário lógico da confirmação da primeira, determinar qual é a sanção aplicável à luz de eventuais sentenças judiciais já proferidas contra o acusado. Limitar a publicização das informações acerca do investigado 
ou acusado e adotar a césure são meios de reduzir o efeito estigmatizante causado pela notícia das condenações anteriores e de evitar "interferência de preconceitos da magistratura quanto a reincidentes, no plano da apreciação das provas". 254

O sistema penal e processual português empregou o primeiro método, pois escalonou o julgamento em duas fases autônomas e sucessivas. $\mathrm{O}$ artigo $71^{\circ}$, número 2 , alínea "e", do Código Penal lusitano ${ }^{255}$ impõe que deve ser aferido, para determinação da culpa e imposição da pena, o comportamento do agente anterior e posterior ao fato. A audiência de instrução e julgamento é unitária, mas de acordo com os artigos $368^{\circ}$ e $369^{\circ}$, ambos do Código de Processo Penal português, ${ }^{256}$ cinde-se a sentença para analisar a culpabilidade e, em seguida, determinar a sanção com expressa menção para que, no segundo momento, seja feita a avaliação dos antecedentes criminais do argüido. Essa prática, segundo Catarina Veiga, denomina-se "sistema de césure" na sentença. Aliás, propõe a autora seja permitido ao juiz conhecer os antecedentes criminais do acusado, mediante análise do certificado do registro criminal, somente ao elaborar a sentença, depois de ultrapassada a audiência de discussão, no momento em que o julgador, mentalmente, já tiver chegado à convicção acerca do mérito da acusação. ${ }^{257}$

O "sistema de césure" no julgamento foi difundido pelos seguidores da Escola da Defesa Social que pregavam a inicial aferição da culpabilidade, ou seja, proporcionar ao juiz conhecer o fato na sua totalidade. Em fase sucessiva o juiz aplicaria o "processo de defesa social" e analisaria as características individuais do agente para fixação da pena apropriada. Esse sistema de segmentação do julgamento de mérito seguido do julgamento relativo à sanção a impor resulta em vantagens e desvantagens. Ele é promissor, pois permite não divulgar preliminarmente os antecedentes do acusado, reduzindo sua estigmatização. Entretanto causa prejuízo de ordem prática pela inegável lentificação do

\footnotetext{
${ }^{254}$ COSTA, António Manuel de Almeida, op. cit., p. 328-331.

${ }^{255} \mathrm{O}$ número 2 e a alínea "e" do artigo $71^{\circ}$ do Código Penal português, que trata da determinação da medida da pena, impõem que na determinação concreta da pena o tribunal atende todas as circunstâncias que, não fazendo parte do tipo de crime, depuserem a favor do agente ou contra ele, considerando, entre outras, a conduta anterior ao fato e a posterior a esse, especialmente quando essa seja destinada a reparar as conseqüências do crime. $O$ número 3 desse artigo da lei penal determina que na sentença sejam expressamente referidos os fundamentos da medida da pena (PORTUGAL. Código Penal Português. Disponível em: <http://www.unifr.ch/ddp1/derechopenal/legislacion/pt/CPPortugal.pdf $>$. Acesso em: 6 jan. 2008).

${ }^{256}$ O número 1 do artigo $369^{\circ}$ do Código de Processo Penal português, que trata da determinação da sanção, dispõe: "Se, das deliberações e votações realizadas nos termos do artigo anterior, resultar que ao argüido deve ser aplicada uma pena ou uma medida de segurança, o presidente lê ou manda ler toda a documentação existente nos autos relativa aos antecedentes criminais do argüido, à perícia sobre sua personalidade e ao relatório social" (PORTUGAL. Associação Sindical dos Juízes Portugueses. Legislação. Lei no 59/98, de 25 de Agosto - Código de Processo Penal. Disponível em: $<$ http://www.unifr.ch/ddp1/derechopenal/legislacion/pt/CProcPenPortugal.pdf $>$. Acesso em: 6 jan. 2008).

${ }^{257}$ Op. cit., p. 112,116 e 119-136.
} 
processo penal, sem ampliação direta das faculdades da defesa, acrescido pela inexorável "circunstância de o direito penal do facto rapidamente se transformar num direito penal de autor", sem falar no risco prático de transferir aos experts a avaliação da personalidade do agente e até a própria aplicação da reação penal. Fundamentalmente, o "sistema de césure" no julgamento peca, porque não permite levar "em consideração que o facto e a pessoa que o pratica são inseparáveis". Essa avaliação é salutar desde que, ao tomar conhecimento dos dados da personalidade do agente, o juiz não reduza a necessidade de a acusação provar o fato e as circunstâncias da sua prática. ${ }^{258}$

A adoção de regras semelhantes às empregadas no sistema anglo-saxônico, no qual se faculta ao juiz acesso aos antecedentes penais em momento posterior, depois de estabelecida a qualificação jurídica dos fatos e definida a responsabilidade penal ao agente, também foi discutida na Espanha. Argumentou-se que isso colocaria a legislação do país em consonância com antigas propostas de divisão do processo penal em duas fases. A primeira destinada à averiguação dos fatos e pronunciamento do juízo de culpabilidade. A segunda designada à individualização da pena e análise de outras conseqüências aplicáveis ao autor do delito. A divulgação dos antecedentes penais aos juízes e tribunais também precisaria submeter-se a regras temporais, pois teria de estar limitada aos lapsos de reabilitação e reincidência, não devendo em caso algum facultar conhecimento de antecedentes cancelados, entendimento que se contrapõe ao regramento atual do artigo 136, número 4, parte final, do Código Penal espanhol no qual está disposto que os certificados penais serão fornecidos sempre que solicitados por juízes ou tribunais, estejam ou não cancelados. Em relação ao fornecimento aos juízes e tribunais de certidões referentes a inscrições canceladas já foi afirmado que essa determinação carece de argumentação jurídica. ${ }^{259}$

Embora seja indispensável conhecer esses dois métodos em virtude da relação guardada com o registro criminal, é possível observar que eles não encontram campo fértil para eventual incorporação ao processo criminal brasileiro, porque além dos efeitos desfavoráveis gerados pela césure, a seguir explicitados, eles exigiriam remodelar grande parte dos fundamentos do processo penal nacional e, especialmente, alterar práticas há muito instituídas pela lei e incorporadas à prática policial e judiciária.

Há dificuldades estruturais para adotar-se a césure no Brasil, bastando pensar que o sistema legislativo vigente impõe à autoridade policial, desde o início da investigação,

\footnotetext{
${ }^{258}$ VEIGA, Catarina, op. cit., p. 99-111.

${ }^{259}$ GROSSO GALVAN, Manuel, op. cit., p. 213-214.
} 
juntar ao inquérito a folha de antecedentes do investigado conforme previsão do artigo $6^{\circ}$, inciso VIII, parte final, do Código de Processo Penal, bem como que o inquérito policial ou as peças de informação acompanharão a denúncia ou queixa, sempre que servirem de base a uma ou outra, conforme dispõe a atual redação do artigo 12 do Código de Processo Penal.

É difícil imaginar, mesmo que fosse alterada a lei processual penal, pudesse ser o responsável pela investigação alijado de conhecer eventuais dados criminais do investigado ou que as informações relativas aos antecedentes criminais do acusado, produzidas durante a investigação, não fossem transferidas ao juiz ou reproduzidas a partir do limiar da fase processual.

A defesa da idéia de restrição das informações completas sobre o conteúdo do registro criminal ao juiz, antes da produção das provas em audiência, não é absoluta, pois dela se ressalvam as hipóteses do necessário conhecimento do passado criminal do acusado para subsunção da conduta ou averiguação da culpa relacionada ao fato. Nessas situações, tal circunstância deve ser levada ao conhecimento do julgador, desde o início do processo, pela acusação. ${ }^{260}$

Como exemplo disso, nota-se que a legislação brasileira exige o conhecimento dos antecedentes criminais do acusado para caracterização da contravenção penal de posse não justificada de instrumento de emprego usual na prática de furto, prevista no artigo 25 do Decreto-Lei no 3.688 , de $19411^{261}$

No mesmo sentido, mas com menor ênfase, o artigo 180, parágrafo $3^{\circ}$, do Código Penal, ao descrever a receptação culposa e indicar a "condição de quem" oferece a coisa para permitir seja presumida sua obtenção por meio criminoso, também faculta exigir o conhecimento pretérito dos antecedentes do agente.

Analisados os dois métodos que sugerem procrastinar ao juiz o conhecimento dos antecedentes criminais do acusado, convém passar à outra discussão.

Neste ponto, atinge-se o momento de defender a idéia de que os interesses da justiça e dos órgãos a ela ligados quanto ao conhecimento dos antecedentes criminais dos investigados e acusados podem ser satisfeitos sem causar danos à privacidade e ampliar

\footnotetext{
${ }^{260}$ VEIGA, Catarina, op. cit., p. 127.

${ }^{261}$ A redação do mencionado artigo da Lei das Contravenções Penais é a seguinte:

"Posse não justificada de instrumento de emprego usual na prática de furto

Art. 25 - Ter alguém em seu poder, depois de condenado por crime de furto ou roubo, ou enquanto sujeito à liberdade vigiada ou quando conhecido como vadio ou mendigo, gazuas, chaves falsas ou alteradas ou instrumentos empregados usualmente na prática de crime de furto, desde que não prove destinação legítima: Pena - prisão simples, de 2 (dois) meses a 1 (um) ano, e multa."
} 
riscos à liberdade da pessoa. Isso pode ser alcançado pela regulação do acesso aos dados do registro disponível às autoridades e aos particulares, especialmente, por meio da adoção de mecanismos relativos ao cancelamento das anotações nele inseridas, quando esses dados não gerem reflexos penais ou processuais, principalmente pelo decurso de lapso temporal ou satisfação de certos requisitos, como a obtenção da reabilitação. ${ }^{262}$

A proposta não se funda no emprego do "sistema de césure" ou qualquer método de "bipartição do julgamento", antes apresentados e, como visto, adotados em outros países. As dificuldades reveladas por esses métodos, entre elas a significativa lentificação do processo $^{263}$ e a divergência estrutural com a maior parte dos procedimentos utilizados no julgamento processual penal brasileiro, desaconselham segui-los.

A regulação do acesso e o cancelamento de determinadas anotações lançadas no registro são propostas cuja adoção, especialmente, permite restringir, sem vedar, o acesso às informações contidas no registro criminal, ou seja, tendo em vista esse enfoque o registro criminal pode ser mantido e empregado sob as vertentes da eficiência e do garantismo.

Não permitir aos juízes e tribunais utilizarem sentenças absolutórias com trânsito em julgado, proferidas em relação a determinado acusado, cuja respectiva anotação foi cancelada do registro e impedir a divulgação de outras anotações, também canceladas, evitaria fosse o acusado avaliado por fatos sem reflexos penais, porquanto não foi condenado ou cumpriu medida de segurança. Esses fatos, submetidos à análise anterior sem resultar na imposição de pena ou medida de segurança, não devem servir para causar prejuízo ao investigado ou acusado, sujeito à eventual e futura condenação, ainda que isso não surja de modo explícito, mas pelo mero conhecimento das mencionadas decisões a partir do exame do seu registro criminal. Nessas hipóteses, as anotações anteriores do registro criminal do acusado, sem resultado condenatório, geraria punição por "mera suspeita" e causaria violação do "princípio do in dubio pro reo ou da presunção de inocência". Esse posicionamento reflete visível antagonismo, pois se na ação penal anterior houve desfecho favorável, o desenlace benéfico seria levado em conta para sustentar

262 COSTA, António Manuel de Almeida, op. cit., p. 331-351. O autor estuda essa questão, levantando dificuldades e virtudes da adoção dessa postura.

${ }^{263}$ Essa posição se reforça a partir das alterações introduzidas no Código de Processo Penal pelas Leis $n^{\text {os }}$ 11.689 e 11.690 , ambas de 9 de junho de 2008, e Lei $\mathrm{n}^{\circ} 11.719$, de 20 de junho de 2008, pois referidas leis trouxeram ao sistema processual brasileiro "modificações [...] profundas. Inspiradas no Código Modelo de Processo Penal Ibero-Americano, que serviu de base para a reforma levada a efeito na última década em diversos países latino-americanos, as novas leis tratam do procedimento do júri, da prova e do procedimento em geral, e objetivam modernizar o processo penal e alcançar a tão esperada celeridade e efetividade" (QUITO, Carina (Coord.). A esperada reforma processual penal. São Paulo, Boletim IBCCrim, n. 188, p. 1, jul. 2008). 
posicionamento mais rigoroso no caso de ser ajuizada nova ação penal para apurar outro crime imputado ao mesmo acusado. ${ }^{264}$

Em outras palavras, de modo objetivo, a absolvição anterior ou outra decisão nãocondenatória anotadas no registro indicariam ao julgador que aquela pessoa conseguiu “escapar” da Justiça, mas posteriormente deverá sofrer punição porque beneficiada pela anterior decisão.

O conhecimento antecipado de todo o conteúdo do registro criminal pode servir como meio para o juiz considerar "mais facilmente provada a responsabilidade do arguido pelo facto que vem acusado". Essa avaliação pode, também, "indirectamente, violar o fundamental princípio da presunção de inocência" e contribuir para que o princípio in dubio pro reo, considerado corolário do primeiro, seja contrariado e transforme-se em espécie de in dubio contra reo, na hipótese de o acusado ostentar anotações no registro. Nesse caso, o conhecimento do envolvimento com a prática de crimes anotados no registro criminal desempenha o papel de "presunção empírica de culpa do agente". 265

Essa forma de interpretar os dados reunidos no registro criminal deve ser evitada sob pena de reduzir a importância da análise da culpa e dar relevo impróprio aos antecedentes criminais.

Em determinadas situações, a doutrina portuguesa propõe que certas modalidades de registros inacessíveis sejam consultados. $\mathrm{O}$ entendimento da inviabilidade de acessar os dados contendo anotações relativas às sentenças absolutórias e decisões concessivas de anistia ou reabilitação comporta três exceções:

a) revisão da sentença condenatória, pois nessa situação todas as informações conhecidas deverão ser facultadas ao tribunal;

b) exames médicos e psicológicos para verificação da personalidade ou do estado mental do acusado;

c) quando a notícia da infração cancelada é requerida a favor do acusado com a finalidade de provar sua inocência.

\footnotetext{
${ }^{264}$ COSTA, António Manuel de Almeida, op. cit., p. 331-333. O autor menciona, especialmente, na nota 638, que sua interpretação é resultado do princípio inserido no artigo $32^{\circ}$, número 2 , da Constituição Portuguesa de 1976, revista em 1982. Os números 1 e 2 do artigo $32^{\circ}$, que tratam das garantias de processo criminal, estão redigidos do seguinte modo: " 1 . O processo criminal assegura todas as garantias de defesa, incluindo o recurso. 2. Todo o argüido se presume inocente até ao trânsito em julgado da sentença de condenação, devendo ser julgado no mais curto prazo compatível com as garantias de defesa."

${ }^{265}$ VEIGA, Catarina, op. cit., p. 123-124.
} 
Entre elas, a situação mais candente é a última, porque o cancelamento das informações do registro criminal pretende impedir a estigmatização social do condenado, evitar a fixação de penas rigorosas sem justificação objetiva e ampliar a aplicação do princípio in dubio pro reo. Nessa hipótese, entretanto, a divulgação da informação funcionará em benefício do acusado possibilitando, mediante autorização expressa do interessado, obtenção de informações acerca da decisão absolutória, anistia e reabilitação. ${ }^{266}$

A posição doutrinária referida e as exceções mencionadas indicam que existe justificativa para deferir eventuais requerimentos de acesso ao registro criminal, pois, embora certos dados pela sua natureza e pelo seu cancelamento normalmente não estejam acessíveis às autoridades, poderão ser eles objetos de consultas extraordinárias.

\subsection{Acesso para fins particulares e administrativos}

A idéia de que a finalidade do registro criminal é "conferir publicidade aos antecedentes penais do indivíduo" impõe verificar ser questão relevante ao estudo do tema o acesso aos cadastros. ${ }^{267}$

É no campo do acesso aos dados compilados nos arquivos que surgem problemas ligados à prevenção geral e especial da prática delituosa. Nesse âmbito, deve ser ressaltada, ainda, a questão da dignidade humana ligada à infâmia que atinge aquele que sofreu condenação criminal devassada. $\mathrm{O}$ interesse pela divulgação do cadastro poderá atender fins processuais, particulares ou administrativos e, também, satisfazer objetivos tendentes à investigação criminológica e elaboração da estatística criminal. Sem discorrer sobre a última finalidade, nota-se que a busca dos dados dos cadastros pelos particulares e pela administração somente encontra respaldo no interesse da manutenção da defesa individual ou coletiva, enquanto que no campo processual penal o registro criminal contribui para o reconhecimento da reincidência e permite regular a modulação da pena, servindo como verdadeiro "meio de prova". Portanto, dependendo da ótica sob a qual for tomado, o registro criminal será regido por regimes jurídicos diversos. ${ }^{268}$

O acesso para fins particulares e administrativos é legítimo para satisfazer o

\footnotetext{
${ }^{266}$ COSTA, António Manuel de Almeida, op. cit., p. 351-353.

${ }^{267}$ Id., ibid., p. 246.

${ }^{268}$ Id., ibid., p. 255-256.
} 
interesse de defesa social, porque há natural retração dos membros da comunidade diante das pessoas condenadas. Entretanto, ao lado dessa idéia, há uma questão de fundo de difícil resposta. Como é possível a convivência das pessoas condenadas, particularmente depois do cumprimento das penas, com os demais integrantes da comunidade, pois se supõe que aquelas estão preparadas e não voltarão à delinqüência e, ao mesmo tempo, se permite sejam acessados os seus registros com anotações de natureza criminal, em verdadeira demonstração de que a ressocialização é meta inatingível?

Exigem-se, também, informações relativas aos antecedentes criminais daqueles que desejam ocupar determinados cargos públicos, providência por vezes descrita nos regulamentos da própria atividade. ${ }^{269}$

Foi assinalado que na Espanha, por exemplo, aqueles que pretendiam contratar com a administração pública, obter passaporte, bolsa de estudos, licença para caçar ou usar armas deveriam apresentar certificado do registro criminal sem anotações. Nesse mesmo país, ainda, o exercício de determinados empregos e a inclusão em certas categorias profissionais também estiveram precedidos dessa exigência. ${ }^{270}$

A divulgação de informações reunidas no registro, especialmente quando possam ser canceladas, potencializa os efeitos estigmatizantes do dado e prejudica o caminho de retorno do condenado ao convívio social. Em razão desse aspecto, é importante observar o reduzido volume de normas reguladoras da proteção dos dados se comparadas àquelas que

\footnotetext{
269 No Estado de São Paulo o artigo 291 da Constituição Estadual tratou da emissão das certidões e informações criminais. Entretanto, seu texto não observou o que consta artigo 202, da Lei de Execução Penal, pois dispõe que "todos terão o direito de em caso de condenação criminal, obter das repartições policiais e judiciais competentes, após reabilitação [...] certidões e informações de folha corrida, sem menção aos antecedentes, salvo em caso de requisição judicial, do Ministério Público, ou para fins de concurso público" enquanto a legislação federal apontou que "cumprida ou extinta a pena, não constarão da folha corrida, atestados ou certidões fornecidas por autoridade policial ou por auxiliares da Justiça, qualquer notícia ou referência à condenação, salvo para instruir processo pela prática de nova infração penal ou outros casos expressos em lei". É possível verificar, portanto que a norma estadual paulista condicionou a emissão de certidão e informações sem referência aos antecedentes à prévia concessão da reabilitação, ao passo que a lei federal exige simples cumprimento ou extinção da pena. O texto da Constituição Estadual, indiretamente, também permitiu a emissão de certidão referente a inquérito policial arquivado, pois inexiste previsão legal que permita deferir-se pedido de reabilitação nesse caso. Nesse aspecto, o mencionado artigo da Constituição Estadual paulista contrariou a norma fixada por outra lei federal, ou seja, o parágrafo único do artigo 20, do Código de Processo Penal, que dispõe que "nos atestados de antecedentes que lhe forem solicitados, a autoridade policial não poderá mencionar quaisquer anotações referentes a instauração de inquérito contra os requerentes, salvo no caso de existir condenação anterior". Finalmente a legislação estadual permitiu à Administração ter acesso ao registro criminal da pessoa candidata a qualquer área do serviço público, sem restringir a necessidade desse conhecimento aos candidatos a determinados cargos ou funções públicas. Finalmente, equiparou o acesso judicial, do Ministério Público ou da Administração para fins de concurso público, ao acesso de terceiros. O tratamento que referido artigo da Constituição Estadual conferiu ao tema destoa da normatização federal, não se preocupou com a ressocialização do condenado e permite divulgar informações relativas a inquérito policial arquivado.

${ }^{270}$ GROSSO GALVAN, Manuel, op. cit., p 221-222.
} 
disciplinam os mecanismos de funcionamento do sistema. ${ }^{271}$

Nota-se, portanto, que há um dilema entre as concepções que surgem do estudo do acesso ao registro criminal para fins particulares e administrativos, porque é difícil conciliar a idéia, perfeitamente extraível da própria existência do registro criminal, de que os condenados são "perigosos" com a de ressocialização, ou seja, da admissão de aptidão do condenado ao respeito dos valores jurídicos-criminais depois de cumprir a pena. Ao lado disso, permanece latente a preocupação de que o registro criminal não deve ser criminógeno, isto é, não deve ampliar as naturais dificuldades para reinserção social dos condenados. $^{272}$

As acentuadas taxas de reincidência daqueles que encerram o cumprimento das penas prisionais servem como fundamento para que a sociedade justifique a necessidade de conhecer os registros criminais das pessoas em determinadas situações, como ocorre nos casos da seleção dos candidatos aos empregos públicos e privados.

É possível verificar que a preocupação com a ressocialização do condenado durante a execução da pena não deve ser interrompida ao término da sanção. Depois do cumprimento da pena, o registro criminal não deverá funcionar como mecanismo para dificultar a reinserção social do condenado, apesar das altas taxas de reincidência, essencialmente, porque a Constituição Federal fixou como um dos objetivos fundamentais da República Federativa do Brasil, entre outros, o repúdio a qualquer forma de discriminação. ${ }^{273}$

Tentativas para o encaminhamento dos questionamentos apresentados permitem oferecer respostas antagônicas. É possível imaginar a vedação do acesso ao registro pelos particulares, incluído o próprio titular do cadastro, facultando-se somente às autoridades, idéia que não é estimulada nem mesmo pelos mais radicais defensores da restrição da publicidade dos dados do registro criminal. ${ }^{274}$ Por outro lado, cabe pensar, também, na possibilidade de franquear o acesso aos dados cadastrais a quaisquer interessados.

Entretanto respostas "radicais" parecem não apresentar soluções satisfatórias aos problemas levantados.

Quanto às taxas elevadas de reincidência, convém ressaltar que, por si, elas só não

${ }^{271}$ GROSSO GALVAN, Manuel, op. cit., p. 128.

272 COSTA, António Manuel de Almeida, op. cit., p. 257-258.

${ }^{273}$ Artigo $3^{\circ}$, inciso IV.

${ }^{274}$ COSTA, António Manuel de Almeida, op. cit., p. 261, especialmente, nota de rodapé no 489 e, também, p. 270 . 
servem para afastar a ressocialização como objetivo da execução penal, pois é provável que se distanciar dessa meta amplie ainda mais o índice de reincidência. Ao medir a reincidência é necessário explicitar quais são as espécies de sanções, os tipos de delitos e a natureza dos delinqüentes em que se encontram maiores taxas de recidiva e, também, verificar quais são os modelos de tratamento penal que ampliam ou reduzem a tendência individual de retornar ao crime. Cabe observar que a colocação de condenados em estabelecimentos prisionais precários somente leva a inocuizá-los ou incapacitá-los durante o período de cumprimento de pena, podendo gerar expressiva ampliação da taxa de reincidência. $^{275}$

Apontar a execução da pena para a ressocialização do criminoso pode servir ao sentido utilitário de evitar a repetição das práticas de delinqüências por parte dos excondenados, mas ostenta alcance maior, porque se assenta sobre a idéia de "solidariedade humana" que deve nortear a execução penal e é aplicável ao Estado. ${ }^{276} \mathrm{Na}$ República Federativa do Brasil essa concepção deve ser extraída do princípio da dignidade da pessoa humana, que é um dos seus fundamentos descritos na Constituição Federal. ${ }^{277}$

Ao arrematar as idéias alinhavadas até aqui, é possível entender não ser contraditório admitir aos particulares e aos órgãos da administração acessar os cadastros criminais para corresponder à necessidade de defesa individual ou coletiva. $O$ acesso, entretanto, deve ser feito a partir de prévia previsão legal, autorização do interessado, determinação judicial ou existência de justa causa, de modo controlado e visando alertar para a possibilidade da reincidência, sem impedir o ex-condenado de reintegrar-se socialmente.

Essa integração exigirá, como primeira providência, alterar o entendimento que se firmou sobre os antecedentes criminais, ou seja, que eles são fator de "seleção instantânea de mão de obra". 278

Não é simples ou fácil conseguir uma alteração comportamental dessa magnitude, porém é preferível buscá-la a negligenciar sistematicamente as informações prestadas oficialmente aos membros do grupo social necessitados de conhecer se certa pessoa tem um passado criminal. Existe o risco de que os particulares procurem alcançar as informações que precisam empregando meios de natureza privada, sem preocupação com o sigilo e a

\footnotetext{
${ }^{275}$ COSTA, António Manuel de Almeida, op. cit., p. 264-265, especialmente, nota de rodapé 491.

${ }^{276}$ Id., ibid., p. 266.

${ }^{277}$ Artigo $1^{\circ}$, inciso III.

${ }^{278}$ GROSSO GALVAN, Manuel, op. cit., p 360.
} 
segurança da informação, e causando maior prejuízo aos ex-condenados. Nesse campo, convém salientar a importância da assistência pós-prisional exercida pelos patronatos e serviços de apoio aos egressos que trabalham para facilitar-lhes a reintegração social e a obtenção de emprego. Assim, nota-se que um dos caminhos adequados consiste em limitar a natureza dos dados que deverão constar dos certificados expedidos a partir dos cadastros criminais para possibilitar que a busca das informações privadas seja desestimulada e ao mesmo tempo seja reforçada a confiança dos particulares no registro criminal, facultandolhes conhecer o passado criminoso de determinada pessoa dentro daquilo permitido pela legislação. ${ }^{279}$

\subsection{Continuação ao acesso para fins particulares e administrativos}

No campo do acesso particular aos dados do registro criminal é possível conceber a solicitação feita pelo interessado ou terceira pessoa. Quando o interessado formula o pedido em seu próprio nome, pareceria lógico inexistir limites ao fornecimento dessas informações, se não se soubesse que é regra fazer esse tipo de solicitação para atender a obrigação exigida na órbita administrativa, trabalhista ou social. Nas hipóteses em que o pedido é feito por terceira pessoa, autorizada ou não pelo interessado, condicionar a expedição da certidão caso inexistirem anotações no registro da pessoa é o mesmo que dizer que essas anotações existem nos respectivos registros daqueles indivíduos cujas certidões não foram emitidas. $^{280}$

Essa forma de responder os requerimentos de terceiras pessoas, aliás, gera maior estigmatização $^{281}$ em relação ao sujeito cujos dados são pesquisados no registro criminal, porque permite ao interessado, ao obter informação criminal, formular juízo depreciativo diante da mera restrição do acesso rápido ao dado, equiparando, subjetivamente, aquele que cometeu crime grave ao envolvido em prática delituosa menos importante.

É difícil encontrar solução à questão do acesso particular aos dados do registro

${ }^{279}$ COSTA, António Manuel de Almeida, op. cit., p. 267-270.

${ }^{280}$ GROSSO GALVAN, Manuel, op. cit., p. 164.

${ }^{281}$ Francisco Bissoli Filho (op. cit., p. 24) frisa que "a cada dia mais, passam a viger leis penais, processuais penais e de execução penal, que apresentam uma série de dispositivos que admitem a influência dos antecedentes e da reincidência criminal [...] os antecedentes e a reincidência criminal por se constituírem em instrumento de apartheid social, uma vez que os indivíduos detentores de antecedentes ou reincidentes criminais passam a pertencer a um grupo especial de pessoas, diferentes dos demais cidadãos, diferenciados pelo seu estigma, de modo que o sistema penal, a cada dia que passa, se torna mais feroz com este grupo de pessoas, a ponto de organizar banco de registro de dados acerca de indivíduos envolvidos nos processos de criminalização, inclusive via Internet" (itálico original). 
criminal. Entre a posição aparentemente mais correta de facultar exclusivamente aos juízes e tribunais o acesso aos dados do registro e aquela visivelmente menos conveniente de permitir amplo acesso particular aos dados do registro, parece equilibrado defender a posição intermediária centrada na idéia da criação de limites definidos ao fornecimento de informe em razão do status do solicitante. Desse modo, as informações prestadas à Justiça devem ser amplas, os dados fornecidos aos órgãos administrativos autorizados, menos extensos, enquanto aqueles facultados aos particulares deveriam ser mínimos e restringir-se ao essencial.

Esse sistema é adotado pelo registro criminal francês que instituiu acesso escalonado aos informes fornecidos pelos bulletins de casier judiciare. O conteúdo das informações extraídas do registro criminal fornecido pelos referidos boletins varia do grau máximo um até o mínimo três. O primeiro tipo de boletim contém resposta à informação pedida pela Justiça. O tipo dois engloba os informes solicitados pelos órgãos administrativos, enquanto o tipo três representa o máximo de dados possíveis de fornecer a partir das solicitações feitas por particulares.

O sistema adotado na França é resultado da adoção da regra que torna o registro acessível aos órgãos públicos e não inteiramente vedado aos particulares. Em outras palavras, esse critério ou sistema mantém o acesso público e não veda o particular, adotando em relação ao registro criminal aquilo que foi convencionado chamar "princípio da informação privada". ${ }^{282}$

No Brasil, a redução do efeito estigmatizante da divulgação dos dados do registro poderia ser alcançada pelo uso equilibrado dos dados inseridos no registro criminal. Isso ocorreria pela adoção de procedimentos legais que reduzissem a publicidade do registro ao fornecimento da informação necessária aos fins investigativos e judiciais e restringisse o acesso pelo particular ou administração, condicionando o fornecimento dessa informação, caso existisse previsão legal, autorização do interessado, ordem judicial ou justa causa.

O direito que a comunidade possui de obter informações em relação à determinada pessoa não deverá ser facilitado pelos órgãos públicos se a fonte ou o arquivo do qual os dados são extraídos não tem caráter público, assim como ocorre na Espanha com o registro criminal por expressa disposição legal. ${ }^{283}$ No Brasil, o caráter reservado dos dados do registro criminal deveria ser extraído, desde logo, da garantia do sigilo dos dados,

\footnotetext{
${ }^{282}$ GROSSO GALVAN, Manuel, op. cit., p. 219.

${ }^{283}$ Conforme dispõe o número 4 do artigo 136 do Código Penal espanhol, as inscrições de antecedentes penais nas distintas secções do Registro Central de Penados y Rebeldes não serão públicas.
} 
assegurado pelo artigo $5^{\circ}$, inciso XII, da Constituição Federal e da análise de dispositivos esparsos encontrados na legislação processual penal. É importante caminhar na busca do aperfeiçoamento legislativo que permita conceder ao registro criminal, expressamente, caráter não-público e desse modo reduzir discussões acerca do acesso particular aos dados nele contidos.

Ainda no campo da questão do acesso do registro criminal para fins particulares e administrativos, é conveniente ressaltar que somente as condenações devem ser divulgadas por meio dos certificados extraídos do registro criminal em razão da subordinação ao princípio da nulla poena sine iudicio. ${ }^{284}$ Quaisquer fatos e decisões que não decorram de condenação definitiva imposta pelo juízo criminal não devem ser objetos de certificação decorrente da pesquisa nos registros criminais, também, em virtude da observância do princípio da presunção de inocência. ${ }^{285}$

Ressalva-se, entretanto, que, caso exista ordem de prisão expedida contra a pessoa cuja informação é buscada pelo particular mediante consulta ao registro criminal, isso deverá ser comunicado ao interessado, inclusive na hipótese de existir notícia de responsabilidade penal pendente. ${ }^{286}$

Esse posicionamento reduz a repulsa que decorre da publicização da existência de qualquer anotação no registro criminal ou policial e, especialmente, impede que os particulares especulem a partir desse dado.

Ao admitir que "a existência de inquéritos e ações penais em curso não serve ao intuito de auxiliar o agravamento da pena na fase de análise das circunstâncias judiciais do artigo 59 do CP"287 e ao constatar que a Lei de Execução Penal proíbe veicular informações relativas às condenações desde que extinta ou cumprida a pena, salvo para instruir processo para apurar prática de nova infração ou outros casos determinados em lei, ${ }^{288}$ nota-se que carece de razão entender que o particular ou a administração possam conhecer, integralmente, dados do registro criminal de terceira pessoa.

Se há limites para o emprego e o conhecimento do conteúdo do registro, tanto que o

\footnotetext{
${ }^{284}$ COSTA, António Manuel de Almeida, op. cit., p. 282 e p. 298.

${ }^{285}$ O parágrafo único do artigo 20 do Código de Processo Penal impõe à autoridade policial somente mencionar nos atestados de antecedentes criminais a existência de inquérito policial instaurado contra o requerente se existir condenação anterior.

${ }_{286}^{28 U}$ BUNO ARÚS, Francisco, op. cit., p. 74.

${ }^{287} \mathrm{O}$ trecho colocado entre aspas foi extraído da ementa do acórdão proferido no Recurso Especial $\mathrm{n}^{\circ}$ 286.419/SP, Relatora: Ministra Maria Thereza de Assis Moura, da $6^{\mathrm{a}}$ Turma (BRASIL. Superior Tribunal de Justiça. Brasília, DF, 24 de maio de 2007. Lex STJ, São Paulo, v. 216, p. 337, ago. 2007.

${ }^{288}$ Artigo 202 da Lei n ${ }^{\circ} 7.210$, de 1984.
} 
juiz criminal conhecedor de determinados dados do registro sem efeito condenatório não deverá usá-los para recrudescer a sanção fixada, e terceiros não deverão ser informados das condenações sofridas por qualquer quando extinta ou cumprida a pena, é cabível fixar condições para o acesso dos particulares e órgãos da administração pública ao registro criminal.

Enfatiza-se que a certidão extraída do registro criminal para fins administrativos e particulares deve conter apenas informações embasadas em sentença penal condenatória em observância aos princípios da necessidade, da proporcionalidade e da mínima intervenção que também orientam outras hipóteses de acesso. É preciso fazer o balanço entre a proporcionalidade do sofrimento do condenado cujo currículo criminal é publicado em certidões e os eventuais prejuízos aos quais fica sujeita a sociedade no caso do cometimento de outros crimes. Após verificar quais as medidas necessárias e proporcionais, deverá ser escolhida aquela que menor gravame causar ao acusado. É possível, ainda, equiparar o acesso para fins administrativos e particulares à disciplina da medida de segurança, cabendo ressaltar três aspectos que deverão ser analisados: a probabilidade da reiteração criminosa, a gravidade dos delitos que poderão ser cometidos e a ponderação dos prejuízos suportados pelo titular do registro que resultem das diferenças da legislação regulamentadora da matéria. ${ }^{289}$

Em relação ao tema medida de segurança, embora afastado do objeto da análise pretendida neste estudo, é conveniente mencionar que entre ela e os antecedentes penais existe um ponto de contato, porque nos dois é feito "juízo de probabilidade de natureza criminológica", ou seja, permite realizar um "prognóstico do futuro delito com base naquele que já foi cometido". O juízo de perigosidade realizado a partir da probabilidade da repetição de crimes que atinjam severamente a ordem jurídica consiste em forma de pensar que pode supervalorizar as características subjetivas do sujeito em detrimento da análise da direção da personalidade da pessoa avaliada. ${ }^{290}$

Isso permite constatar que tanto no momento de analisar a vida passada do agente inimputável para impor medida de segurança quanto na ocasião de aferir os antecedentes do imputável para aplicar a pena, o juiz deverá posicionar-se de modo especialmente claro e objetivo.

${ }^{289}$ COSTA, António Manuel de Almeida, op. cit., p. 299-300.

${ }^{290}$ GROSSO GALVAN, Manuel, op. cit., p. 72 e 74. 


\subsection{Restrição de acesso para fins particulares e administrativos}

A restrição ao acesso administrativo e particular ao registro pode ser fundada em determinação legal acrescida da análise judicial do caso concreto. Em Portugal, o condenado ao cumprimento de "pena de prisão até um ano ou pena não privativa de liberdade" pode ser beneficiado com determinação judicial para não-transcrição da sentença nos certificados emitidos pelo registro criminal para "fins de emprego" e "outros fins", sempre que o juiz verificar que "das circunstâncias que acompanharam o crime não se puder induzir perigo de prática de novos crimes". ${ }^{291}$

Caso imposta interdição, é possível que ela não seja transcrita nos certificados expedidos para "outros fins" e "finns de emprego" se transcorrida a duração dessa interdição, desde que não relacionada ao emprego, profissão ou atividade que se pretenda exercer, porque aquele que requer certidão do registro em Portugal deve declarar a finalidade do seu pedido. $^{292}$ Também nesse ponto a legislação lusitana foi alterada, pois antes da vigência da lei que tratou da identificação e do registro criminal as incapacidades e interdições profissionais deveriam constar da certidão expedida pelo registro criminal, embora sem qualquer referência à infração cometida. ${ }^{293}$

Além das situações em que é inadequado transcrever anotações do registro criminal em certidões para fins administrativos e particulares, pela reduzida probabilidade de nova condenação que resulta na desnecessidade da adoção dessa medida para incrementar a defesa social, nos casos da aplicação de sanções leves, em homenagem ao princípio da proporcionalidade também é possível evitar a transcrição de informações nas certidões ou certificados emitidos pelo registro para certos fins. $O$ fundamento dessa idéia é a ausência de perigosidade daqueles que sofrem penas dentro desse limite. ${ }^{294}$

Essa posição que sacrifica a defesa social em benefício da ressocialização do criminoso também é admitida em Portugal no caso da expedição de certificados para outros fins, nas seguintes hipóteses:

a) pessoa condenada por contravenção, decorrido seis meses do cumprimento da pena;

\footnotetext{
${ }^{291}$ Artigo $17^{\circ}$, número 1, da Lei 57/98, de 18 de Agosto (VEIGA, Catarina, op. cit., p. 154).

${ }^{292}$ Artigo $11^{\circ}$ e artigo $17^{\circ}$, número 2, da Lei 57/98, de 18 de Agosto (Id., ibid., loc. cit.).

${ }^{293}$ COSTA, António Manuel de Almeida, op. cit., p. 304.

${ }^{294}$ Id., ibid., p. 313-315. Cabe ressaltar a regra brasileira prevista no artigo 76, $\S 4^{\circ}$, da Lei no 9.099, de 1995, que indica não forjar reincidência a aceitação da transação penal.
} 
b) “delinqüentes primários" condenados a cumprir pena de prisão ou equivalente não superior a seis meses, salvo enquanto vigorar interdição decretada pelo juiz, conforme dispõe o artigo $12^{\circ}$, alíneas "a" e "d", da Lei 57/98, de 18 de Agosto. ${ }^{295}$

Para satisfazer a necessidade de obtenção de certificados ou certidões do registro pelos órgãos administrativos essa obrigação poderá ser imposta ao próprio interessado que deverá apresentá-los ao órgão público perante o qual ele se dirige. ${ }^{296}$ Esse procedimento restringe o acesso dos órgãos públicos aos dados do registro e transfere a obrigação ao próprio titular do registro que, a seu modo, poderia optar por transferi-los ou não.

A transferência dessa obrigação ao interessado, entretanto, pode gerar problemas, por exemplo, quem tiver registro que o desabone poderia pensar em substituir o documento legítimo por outro falsificado, e indica falta de estrutura do serviço público em geral, pois agindo assim a administração, em suas diversas áreas de atuação, demonstra desconhecer o sistema de registro. Por fim, estimula a intervenção de intermediários, pessoas que obtêm mais facilmente as certidões necessárias em razão do conhecimento dos procedimentos internos da repartição pública expedidora desse documento.

Melhor seria fosse previsto, nos casos de necessidade de obtenção de certidões ou atestados para concurso público, que o candidato recolhesse tarifa específica para a realização desse serviço em favor do próprio órgão que pretende admiti-lo, que ficaria responsável pela obtenção do documento e evitaria possíveis fraudes, bem como tornaria mais fidedigna a informação obtida.

Na Espanha, o Registro Central de Penados y Rebeldes está obrigado a fornecer informações nele contidas aos tribunais, juízes e órgãos oficiais, embora a falta de indicação expressa de quais sejam esses órgãos ou organismos torna o acesso amplo. Além da necessária enumeração dos órgãos legitimados a solicitar dados ao registro, considera-se importante limitar os casos ou as hipóteses do cabimento do acesso, fixar responsabilidades pelo emprego desvirtuado da informação ou sua cessão a órgãos ou pessoas que não poderiam consegui-la. Nesse sentido, ressalta-se que, desde meados de 1980, a legislação alemã que regulava o Registro Central Federal, à época responsável pelo fornecimento das informações criminais dos cidadãos, também relacionava os órgãos e indicava as situações que permitiam obter informes do registro criminal. O fornecimento dessas informações decorre da aplicação do denominado "princípio da informação oficial ou da informação

\footnotetext{
${ }^{295}$ VEIGA, Catarina, op. cit., p. 151.

${ }^{296}$ GROSSO GALVAN, Manuel, op. cit., p. 217.
} 
pública", a partir do qual o registro criminal se obriga a fornecer informes que reúne a uma série de órgãos. Entretanto, como o cumprimento dessa obrigação resulta na exposição, estigmatização e redução da capacidade de reintegração social dos ex-condenados, o nome dos organismos legitimados e a situação justificante das consultas mereceriam expressa regulação legal. ${ }^{297}$

O emaranhado de idéias que deriva do acesso particular aos dados do registro oferece outras questões, ou seja, o problema que resulta da possibilidade de concederem-se informações irrestritas ao próprio interessado e o uso do documento contendo tais dados para comprovação dos antecedentes para fins de emprego.

A falta de controle dessa utilização permitirá que a entidade privada oferecedora da vaga no mercado de trabalho conheça, amplamente, as informações contidas no registro do candidato, dados que por via direta não the seriam franqueados. A dificuldade de solucionar esse ponto, pode ser minimizada a partir da adoção de regras que norteiem o conteúdo do certificado fornecido ao próprio interessado para "fins de emprego" e para "outros fins" conforme dispõe a legislação lusitana novamente referida. ${ }^{298}$

A questão do acesso particular é pouco discutida no Brasil, pois aqui a sistemática vigente consiste em exigir que o interessado requeira em nome próprio documentos comprobatórios dos antecedentes criminais e forneça-os ao empregador. Quanto ao acesso para fins administrativos, embora a sistemática para obtenção de informações sobre o passado criminal do candidato seja semelhante, a inscrição dessa norma em regulamentos administrativos, legislação local e editais de concurso público permite, em certas hipóteses, avaliar o cabimento dessa exigência e discutir a análise que é feita a partir dos antecedentes eventualmente ostentados pelo interessado na obtenção da ocupação cujo acesso é regulado pela administração.

Exigências dessa natureza devem ser compatíveis com a atividade que se pretende exercer. ${ }^{299}$ É o caso daquele que deseja integrar empresa de segurança privada, pessoa para

\footnotetext{
${ }^{297}$ GROSSO GALVAN, Manuel, op. cit., p. 209-210 e 216.

${ }^{298}$ VEIGA, Catarina, op. cit., p. 148-151.

299 Transcrevendo escrito de Pedro Romero Macías, Jefe del Registro Central de Penados y Rebeldes del Ministerio de Justicia, Francisco Bueno Arús (op. cit, p. 97-98) afirma que "potenciar la actividad laboral es la mejor defensa social contra el delito" e em seguida aponta que "la propia Administración Pública, en su ceguera, viene exigindo en bastantes procedimientos la aportación de la certificación de carencia de antecedentes penales, con carácter genérico, para puestos o empleos sin relacíon alguna con los mismos [...] Así no nos encuentraríamos con situaciones como las actuales, en que un ciudadano no puede acceder a una plaza de agente judicial por no haber podido cancelar los antecedentes penales derivados de un delito de conducción bajo la influencia de bebidas alcohólicas, y si pueda ser educador o tener a cargo menores un ciudadano con antecedentes penales de abusos sobre los mismos al no existir norma legal que exija la
} 
quem no Brasil é exigido comprovar, por meio de certidões, a inexistência de registro criminal. $^{300}$

Entretanto, discute-se a validade de semelhante exigência prevista na Lei $\mathrm{n}^{0} 7.369$, de 1969, do Município de São Paulo. Referida legislação, ao dispor sobre o serviço de transporte de táxi na cidade, veda a inscrição do condenado pela prática de crime doloso no Cadastro Municipal de Empresas de Táxi e também obsta a inscrição de pessoa que ostente a mesma modalidade de condenação no Cadastro Municipal de Condutores de Táxi, impedindo ao condenado pela prática de qualquer crime doloso, inclusive, conduzir um táxi. $^{301}$

A questão não se cinge às exigências inseridas em regulamentos ou legislações locais, mas por vezes é trazida no bojo de editais de concursos públicos nos quais, freqüentemente, condiciona-se o exercício de função pública à prova da inexistência de antecedentes criminais, embora tenha sido entendido que semelhante exigência ofende ao princípio da dignidade humana e despreza o direito social do trabalho, ambos protegidos pelo texto constitucional. ${ }^{302}$

Se o ordenamento jurídico deseja manter a "publicidade restritiva" do conteúdo do registro criminal, deveria proibir a entrega de certidões aos próprios interessados, mesmo se a solicitação partisse de repartição pública. Nesse caso, a autoridade responsável pelo órgão interessado nas informações deveria requerer ao registro criminal o encaminhamento dos certificados ou certidões e decidir o cabimento de dar conhecimento sobre o conteúdo das

carencia de antecedentes penales para desarrollar esa actividad tanto en el ámbito público como en el privado."

300 “Art. 27 - Para obter autorização de funcionamento, o interessado deverá adotar o seguinte procedimento: I - protocolizar, no órgão regional do Departamento de Polícia Federal, requerimento firmado pelo representante legal da empresa, dirigido à Coordenação Central de Polícia do DPF;

II - instruir o requerimento a que se refere o inciso anterior com os seguintes documentos:

a)

$[\ldots]$

d) atestados e certidões negativas de registros criminais expedidos pelos Cartórios de Distribuição das Varas Criminais das Justiças Federal, Militar, Eleitoral e Estadual, dos sócios, diretores, administradores e gerentes, dentro do prazo de validade, comprovando a inexistência de condenação criminal transitada em julgado, nos locais da Federação onde mantenham residências e pretendam constituir a empresa" (PORTARIA DPF N ${ }^{\circ}$ 992, de 25 de outubro de 1995. Trata das Empresas de Segurança Privada. Publicações Eletrônicas Associação Paulista do Ministério Público. São Paulo: APMP, 2004-2006. 1 CD-ROM. Produzido por Eduardo Roberto Alcântara Del-Campo e Marinilce Araújo Soria).

${ }^{301}$ CESTARO, Marcel Del Bianco. A inconstitucionalidade dos efeitos (muitas vezes) perenes resultantes de um processo criminal. Boletim IBCCrim, São Paulo, ano 15, n. 181, p. 6-8, dez. 2007.

302 SABINO, Ferez. Concurso público - Certidão Negativa de Antecedentes Criminais. Exigência que contraria a Constituição. Boletim da Procuradoria Geral do Estado - Centro de Estudos, São Paulo, v. 22, n. 4, p. 495-497, jul./ago. 1999. 
informações obtidas ao interessado. ${ }^{303}$

A análise da doutrina e a ênfase a alguns aspectos significativos da legislação portuguesa em vigor relacionados ao tema, confrontadas com situações peculiares ligadas ao acesso para fins particulares e administrativos no Brasil, indicam a complexidade do assunto e, ao mesmo tempo, servem para mostrar que também nessa área o registro criminal nacional carece de estruturação.

\subsection{Acesso especial e acesso para fins estatísticos e científicos}

Sob o contexto estudado é possível analisar, também, a idéia da especialização ou da relativização do acesso ao registro criminal para fins administrativos e particulares. A proposta do acesso especial funda-se no estabelecimento de um nexo entre as várias finalidades que embasam os pedidos de busca nos cadastros e as modalidades delituosas anteriormente cometidas por determinado indivíduo, de modo que a legislação regulamentadora do assunto apresentaria um catálogo de situações em que seria permitido acessar o registro criminal, condicionando o fornecimento da informação à natureza ou modalidade do delito cometido. Em suma, os adeptos dessa idéia pretendem conectar a hipótese da repetição da prática da mesma modalidade delituosa com a finalidade de acesso ao registro criminal objetivando reduzir a publicidade dos dados e estreitar a possibilidade de expor os condenados à infâmia, por exemplo, conhecerem-se eventuais práticas de crimes de trânsito por alguém que pretenda concorrer ao emprego de motorista. ${ }^{304}$

Esse critério, entretanto, não exibe base segura para permitir a regulação do acesso do registro criminal para fins particulares ou administrativos, ${ }^{305}$ principalmente, porque os estudos criminológicos não são concludentes ao apontar a confirmação da escalada criminosa em relação a delitos da mesma natureza e, tampouco, da existência de especialização nas carreiras criminais. ${ }^{306}$

Parece que essa postura mais se assenta na "opinião generalizada" e "de forte

\footnotetext{
${ }^{303}$ BUENO ARÚS, Francisco, op. cit., p. 75.

${ }^{304}$ COSTA, António Manuel de Almeida, op. cit., p. 271-272. Pode servir, também como exemplo, o caso da babá que praticou maus tratos contra a criança que tinha obrigação de cuidar, profissional cujos dados poderiam ser buscados pelas pessoas que pretendessem contratá-la para exercer a mesma atividade.

${ }^{305}$ Id., ibid., p. 273-276.

${ }^{306}$ Id., ibid., p. 293.
} 
tradição" que considera que o "delinqüente, tarde ou cedo, volta a delinqüir"., 307

Desse modo, não é possível estabelecer exclusivamente fórmulas que tendam a especializar ou relativizar as informações exibidas pelas certidões extraídas do registro criminal, porque as idéias em torno dessa proposta são muito obscuras, sendo impossível prever todas as hipóteses de necessidade de acesso e o catálogo de informações passíveis de divulgação em qualquer dispositivo legal, inclusive, em razão do elevado número de certificados expedidos pelo órgão responsável. ${ }^{308}$

A postura que se mostra adequada, portanto, não é relacionar crimes ou situações em que o acesso administrativo e particular aos dados do registro seja permitido, pois apresentar catálogo com esses conteúdos exige valoração e análises desse tipo são mais próprias de serem feitas no caso concreto, não de modo generalizado, especialmente a partir da aferição de justa causa para o fornecimento da informação, assunto a seguir estudado.

Providência mais acertada em relação ao acesso da administração e do particular ao conteúdo do registro consiste em restringir a oferta de informações antes do trânsito em julgado da condenação desde que inexista qualquer determinação cautelar desfavorável ao sujeito, como decreto de prisão preventiva, por exemplo. A informação deverá ser restringida, também, depois de cumprida ou extinta a pena, exceto nas hipóteses ressalvadas pela lei penal, preservada a obrigatoriedade de fornecer informações nos casos de a condenação resultar em efeitos específicos, tais como perda do cargo em razão de violação de dever para com a administração pública, imposição de incapacidade para o pátrio poder, tutela ou curatela ou determinação de inabilitação para dirigir veículos durante sua vigência, na forma especificamente prevista pela lei penal. ${ }^{309}$

Finalmente, o acesso aos dados do registro criminal para fins estatísticos e de investigação científica deve ser amplo, porque tais dados servirão para estudos doutrinários e propostas legislativas no âmbito penal, os quais poderão, inclusive, indicar soluções para problemas gerados no próprio registro criminal.

O pedido de acesso para atender os estudos estatísticos e a investigação científica que se pretenda fazer, entretanto, merece previsão legal e orientação expressa para que a identidade do titular do registro individual analisado não seja devassada. A legislação

\footnotetext{
${ }^{307}$ GROSSO GALVAN, Manuel, op. cit., p 360.

${ }^{308}$ COSTA, António Manuel de Almeida, op. cit.,p. 295-296. Nesse trecho, especialmente na nota de rodapé 563, o autor descreve o crescimento do número de certificados expedidos pelo serviço de registro criminal português entre os anos de 1980 até 1984 .

${ }^{309}$ Artigo 92 do Código Penal.
} 
portuguesa, ao regular as formas, trata dessa modalidade de acesso, atribuindo ao Ministro da Justiça daquele país a responsabilidade para emissão de autorização para essa modalidade de investigação científica ou estatística. ${ }^{310}$

No Brasil, a estatística criminal ou estatística judiciária criminal é tratada pelo artigo 809 do Código de Processo Penal e pelo Decreto-Lei n ${ }^{0} 3.992$, de 30 de dezembro de 1941. A compilação e análise desses dados são atribuídas aos Institutos de Identificação e Estatística ou a repartições congêneres e ao Serviço de Estatística Demográfica, Moral e Política do Ministério da Justiça. Entretanto não é de conhecimento público o modo da realização desse trabalho, ${ }^{311}$ bem como inexiste previsão legislativa reguladora desse tipo de análise.

\subsection{Justa causa e acesso legal para fins diversos}

Sob a idéia de regular o acesso ao registro criminal, especialmente naqueles casos em que a finalidade do emprego da informação é exclusivamente particular, mostra-se necessário analisar o choque entre o legítimo interesse privado em receber e utilizar informações de que o Estado dispõe frente ao não menos legítimo interesse social da reinserção do condenado. ${ }^{312}$

Diante dos fins contrapostos, cada um deles orientado pela finalidade privada e pública, entende-se que o registro criminal brasileiro deva privilegiar o atendimento do interesse social, explicitado no artigo $2^{\circ}$, caput, da Lei de Execução Penal que, além de impor a efetivação das disposições da sentença ou decisão criminal, prevê ser objetivo da execução penal "proporcionar condições para a harmônica integração social do condenado e do internado".

Nem sempre os órgãos oficiais devem ter acesso irrestrito às informações criminais dos cidadãos enquanto aos particulares também não será facultado conhecer livremente dados do registro criminal de terceiras pessoas. $\mathrm{O}$ acesso às informações, tanto na hipótese da necessidade pública como particular, pressupõe "autêntica correlação entre os fins dos antecedentes e a possibilidade de conceder dita informação". 313

\footnotetext{
${ }^{310}$ VEIGA, Catarina, op. cit., p. 149.

${ }^{311}$ SOBRINHO, Mário Sérgio. A identificação criminal. São Paulo: RT, 2003. p. 109.

${ }^{312}$ GROSSO GALVAN, Manuel, op. cit., p. 163.

${ }^{313}$ Id., ibid., p. 208.
} 
A diversidade das regras relativas ao acesso ao conteúdo do registro criminal e a dificuldade de punir quem fizer uso indevido ou abusivo das informações a partir do acesso irregular, ${ }^{314}$ que permite aos representantes de órgãos públicos e aos particulares conhecer e divulgar indevidamente os antecedentes criminais de certa pessoa, recomendam debater a questão da justa causa antes de verificar em quais situações, estranhas aos fins criminais, a legislação nacional facultará o acesso aos dados do registro criminal.

Não é tarefa fácil apontar a configuração da justa causa autorizadora do acesso particular e mesmo dos órgãos da administração ao conteúdo do registro criminal. Ao estudar a justa causa, Maria Thereza Rocha de Assis Moura considerou difícil, senão impossível, defini-la, por tratar-se de expressão multiforme, justificando que essa “impossibilidade decorre, a nosso ver, precipuamente de dois fatores: 'causa' possui significado vago e ambíguo, enquanto justo constitui um valor". 315

Apesar dessa dificuldade, analisar a legislação portuguesa revogada e vigente relacionada ao tema, bem como buscar nos textos legislativos nacionais mais importantes situações indicativas da obrigatoriedade de aferir o cabimento ao acesso aos dados criminais, especialmente se o pedido for feito por particular, facilitarão entender que é possível apontar a justa causa como fundamento legitimador do acesso aos dados do registro criminal.

Nos primórdios da criação do registro criminal português o interessado somente teria acesso aos dados desde que provasse existir "justa causa da pretensão". No mesmo país, o parágrafo $1^{\circ}$ do artigo $8^{\circ}$ do Decreto, de 17 de Março de 1906 , permitiu que o particular obtivesse informações inseridas no registro criminal referentes à outra pessoa, desde que autorizado pelo juiz competente, "por despacho fundado em interesse atendível do supplicante", existindo previsão de recurso dessa decisão ao Supremo Tribunal de Justiça. ${ }^{316}$

Atualmente, em Portugal, os certificados requeridos por particulares para outros objetivos, ou seja, não relacionados aos fins de emprego público ou privado, podem apresentar conteúdo restrito ou ainda ser recusada sua emissão conforme dispõe o número 3

\footnotetext{
${ }^{314}$ Conforme previsão do artigo $37^{\circ}$ do Decreto-Lei 381/98, de 27 de Novembro (Diário..., cit., p. 6581), em Portugal: "1- São de natureza confidencial todos os dados de identificação criminal constantes do ficheiro e arquivo existentes nos serviços de identificação criminal. 2- Os funcionários e agentes que tomem conhecimento no exercício das suas funções dos dados de identificação criminal referidos no número anterior e, bem assim, os trabalhadores das empresas fornecedoras de equipamentos e serviços estão sujeitos a sigilo profissional, mesmo após o término das suas funções."

${ }^{315}$ Justa causa para a ação penal. São Paulo: RT, 2001. p. 97.

${ }^{316}$ COSTA, António Manuel de Almeida, op. cit., p. 120, nota de rodapé 194, e p. 126.
} 
do artigo $12^{\circ}$ da Lei 57/98, de 18 de Agosto. Nesse caso, o certificado emitido a partir do requerimento particular para finalidades não previstas em lei pode ser limitado ou negado pelo "director-geral dos Serviços Judiciários [...] se o requerente não justificar a necessidade de acesso à informação sobre identificação criminal”. ${ }^{317}$

Nota-se, portanto, nesse país, a existência de tradição legislativa que privilegia a aferição do acesso particular ao registro criminal, em última análise, a partir da avaliação da justa causa.

A noção de justa causa e o seu emprego na legislação lusitana com a função de fundamentar a emissão ou a recusa, integral ou parcial, da expedição de informações a partir do registro criminal permitem considerar que no Brasil se deveria atribuir aos órgãos da justiça criminal a função de autorizar, motivadamente, o acesso aos mencionados dados no caso de omissão legislativa, desde que demonstrado ser necessário obter esses dados.

Ao discorrer sobre a normatização inserida no artigo 136.4 do Código Penal, no qual estão reunidos os princípios gerais sobre o Registro Central de Penados y Rebeldes, Francisco Bueno Arús indica que "las inscripciones de antecedentes penales no serán públicas”. Nesse trecho do estudo, o autor afirma que essa disposição permite entender que tais informações devem ser consideradas dados sensíveis, pertencentes à honra e intimidade do indivíduo, não devendo estar disponíveis para terceiros sem consentimento do titular, "a menos naturalmente que concurra un interés preponderante sobre el interés del condenado a guardar el dato secreto." 318

Embora o autor mencionado não trate da existência de justa causa legitimadora do acesso aos dados do registro criminal, mas firme a necessidade de lei reguladora dos casos em que se permita busca no registro, ao referir-se à idéia de "interesse preponderante ao acesso que sobrepuje o interesse do condenado ao segredo", permite entender que a fixação por lei das mencionadas hipóteses deverá ser antecedida da existência de justa causa legitimadora do acesso aos dados do registro criminal.

Uma das questões cujo encaminhamento é dos mais difíceis se situa na delimitação das hipóteses em que os dados inseridos no registro criminal poderão ser divulgados aos particulares e aos órgãos públicos estranhos ao sistema de Justiça Criminal em virtude de exigência legal ou fática. As idéias que deverão nortear os estudos estão sedimentadas no princípio da legalidade e da proporcionalidade e, especialmente, na existência de justa

${ }^{317}$ VEIGA, Catarina, op. cit., p. 151.
${ }^{118}$ Op. cit., p. 73. 
causa legitimadora para o pretendido acesso aos dados do registro criminal.

O Código Civil brasileiro traz previsões cuja comprovação exige a apresentação das cópias de sentenças ou decisões criminais indicativas da prática de crime.

Poderá ser necessário, inicialmente, obter informações armazenadas no registro criminal para comprovar esses crimes. Isso pode ocorrer em várias situações, destacando-se entre elas:

a) revogação de doação por ingratidão comprovada pela prática de homicídio contra o donatário, cometimento de ofensa física, injúria ou calúnia; ${ }^{319}$

b) vedação do exercício da administração de sociedade por pessoa condenada por crime falimentar, de prevaricação, peita ou suborno, concussão, peculato, ou contra a economia popular, o sistema financeiro nacional, as normas de defesa da concorrência, as relações de consumo, a fé pública ou a propriedade, enquanto perdurarem os efeitos da condenação, bem como quando ao sujeito é vedado o acesso aos cargos públicos ainda que temporariamente; ${ }^{320}$

c) erro essencial sobre a pessoa do outro cônjuge para fins de anulação de casamento fundado na ignorância de crime, anterior ao casamento, que, por sua natureza, torne insuportável a vida conjugal; ${ }^{321}$

d) impossibilidade de manutenção da vida em comum pela prática de crime infamante; ${ }^{322}$

319 “Art. 557. Podem ser revogadas por ingratidão as doações:

I - se o donatário atentou contra a vida do doador ou cometeu crime de homicídio doloso contra ele;

II - se cometeu contra ele ofensa física;

III - se o injuriou gravemente ou o caluniou;

IV - se, podendo ministrá-los, recusou ao doador os alimentos de que este necessitava."

320 "Art. 1.011. O administrador da sociedade deverá ter, no exercício de suas funções, o cuidado e a diligência que todo homem ativo e probo costuma empregar na administração de seus próprios negócios.

$\S 1^{\circ}$ Não podem ser administradores, além das pessoas impedidas por lei especial, os condenados a pena que vede, ainda que temporariamente, o acesso a cargos públicos; ou por crime falimentar, de prevaricação, peita ou suborno, concussão, peculato; ou contra a economia popular, contra o sistema financeiro nacional, contra as normas de defesa da concorrência, contra as relações de consumo, a fé pública ou a propriedade, enquanto perdurarem os efeitos da condenação.

$\S 2^{\circ}$ Aplicam-se à atividade dos administradores, no que couber, as disposições concernentes ao mandato."

321 “Art. 1.557. Considera-se erro essencial sobre a pessoa do outro cônjuge:

I - o que diz respeito à sua identidade, sua honra e boa fama, sendo esse erro tal que o seu conhecimento ulterior torne insuportável a vida em comum ao cônjuge enganado;

II - a ignorância de crime, anterior ao casamento, que, por sua natureza, torne insuportável a vida conjugal;

III - a ignorância, anterior ao casamento, de defeito físico irremediável, ou de moléstia grave e transmissível, pelo contágio ou herança, capaz de pôr em risco a saúde do outro cônjuge ou de sua descendência;

IV - a ignorância, anterior ao casamento, de doença mental grave que, por sua natureza, torne insuportável a vida em comum ao cônjuge enganado."

322 "Art. 1.573. Podem caracterizar a impossibilidade da comunhão de vida a ocorrência de algum dos 
e) suspensão do poder familiar ao pai ou mãe condenados por sentença irrecorrível em virtude de crime cuja pena exceda a dois anos de prisão; ${ }^{323}$

f) proibição de exercer a tutela e afastamento do exercício desse encargo ao condenado por crime de furto, roubo, estelionato, falsidade, contra a família ou os costumes, tenha ou não cumprido pena; ${ }^{324}$

g) exclusão da sucessão dos herdeiros ou legatários autores, co-autores ou partícipes de homicídio doloso, ou tentativa deste, contra a pessoa de cuja sucessão se tratar, seu cônjuge, companheiro, ascendente ou descendente. ${ }^{325}$

$\mathrm{Na}$ Espanha, juízes e tribunais não-criminais podem obter informações relativas aos antecedentes criminais de determinada pessoa para motivar pedidos de separação, nulidade matrimonial e divórcio, com base em regra antiga estabelecida na Real Orden, de 1 de abril de 1896. Mediante procedimento estabelecido o pedido de antecedentes criminais é enviado ao chefe do registro criminal que o encaminhará ao Ministro da Justiça o qual ante as razões do pedido autorizará ou não a emissão das informações. ${ }^{326}$

seguintes motivos:

I - adultério;

II - tentativa de morte;

III - sevícia ou injúria grave;

IV - abandono voluntário do lar conjugal, durante um ano contínuo;

$\mathrm{V}$ - condenação por crime infamante;

VI - conduta desonrosa.

Parágrafo único. O juiz poderá considerar outros fatos que tornem evidente a impossibilidade da vida em comum."

323 “Art. 1.637. Se o pai, ou a mãe, abusar de sua autoridade, faltando aos deveres a eles inerentes ou arruinando os bens dos filhos, cabe ao juiz, requerendo algum parente, ou o Ministério Público, adotar a medida que lhe pareça reclamada pela segurança do menor e seus haveres, até suspendendo o poder familiar, quando convenha.

Parágrafo único. Suspende-se igualmente o exercício do poder familiar ao pai ou à mãe condenados por sentença irrecorrível, em virtude de crime cuja pena exceda a dois anos de prisão."

324 “Art. 1.735. Não podem ser tutores e serão exonerados da tutela, caso a exerçam:

I - aqueles que não tiverem a livre administração de seus bens;

II - aqueles que, no momento de lhes ser deferida a tutela, se acharem constituídos em obrigação para com o menor, ou tiverem que fazer valer direitos contra este, e aqueles cujos pais, filhos ou cônjuges tiverem demanda contra o menor;

III - os inimigos do menor, ou de seus pais, ou que tiverem sido por estes expressamente excluídos da tutela; IV - os condenados por crime de furto, roubo, estelionato, falsidade, contra a família ou os costumes, tenham ou não cumprido pena;

$\mathrm{V}$ - as pessoas de mau procedimento, ou falhas em probidade, e as culpadas de abuso em tutorias anteriores; VI - aqueles que exercerem função pública incompatível com a boa administração da tutela."

325 “Art. 1.814. São excluídos da sucessão os herdeiros ou legatários:

I - que houverem sido autores, co-autores ou partícipes de homicídio doloso, ou tentativa deste, contra a pessoa de cuja sucessão se tratar, seu cônjuge, companheiro, ascendente ou descendente;

II - que houverem acusado caluniosamente em juízo o autor da herança ou incorrerem em crime contra a sua honra, ou de seu cônjuge ou companheiro;

III - que, por violência ou meios fraudulentos, inibirem ou obstarem o autor da herança de dispor livremente de seus bens por ato de última vontade."

${ }^{326}$ GROSSO GALVAN, Manuel, op. cit., p. 167. 
O campo processual civil também pode indicar situações a partir das quais se mostra necessário acessar o registro criminal. Nesse aspecto, o Código de Processo Civil brasileiro concebe que pessoa condenada, irrecorrivelmente, por praticar crime de falso testemunho, ao apresentar-se para ser ouvida como testemunha, deve ser considerada suspeita. ${ }^{327}$ Essa norma pode refletir em pedido justificado do autor ou do réu apresentado ao juiz para obter prova da condenação que se pretende alegar.

A Consolidação das Leis do Trabalho indica as seguintes situações que poderão ser comprovadas a partir da consulta de dados inseridos no registro criminal:

a) rescisão do contrato de trabalho;

b) suspensão do exercício funcional do profissional químico;

c) impedimento para exercer cargo eletivo sindical. ${ }^{328}$

Aliás, apesar de encontrarem-se definidas pela legislação trabalhista as situações que permitem relacionar dados do registro criminal às situações laborais, nessa área surgem efeitos imponderáveis em relação às pessoas que ostentam anotações no registro criminal. Tais efeitos são percebidos antes da formalização da relação trabalhista, especialmente se o informe contendo indicação dos antecedentes criminais do candidato à vaga de trabalho for conhecido antecipadamente pelo pretenso empregador ou for considerado como causa de rejeição daquele que pretende trabalhar, sem análise do conteúdo da informação. ${ }^{329}$

No campo dos direitos políticos, a Constituição Federal dispõe no artigo 14, $\S 4^{\circ}$, que são inelegíveis os inalistáveis e os analfabetos. A seguir, no $\S 9^{\circ}$, do mesmo artigo, alterado pela Emenda Constitucional de Revisão nº 4, de 1994, é afirmado que outros casos de inelegibilidade e os prazos de sua cessação serão regulados por lei complementar. A finalidade dessa norma, inserida no texto constitucional, é proteger a probidade administrativa e a moralidade para o exercício do mandato por meio da análise da vida

327 “Art. 405. Podem depor como testemunhas todas as pessoas, exceto as incapazes, impedidas ou suspeitas. $\S 1^{\circ}[\ldots]$

$\S 3^{\circ}$ São suspeitos:

I - o condenado por crime de falso testemunho, havendo transitado em julgado a sentença;

II $-[\ldots]$

$\S 4^{\mathrm{o}}$ Sendo estritamente necessário, o juiz ouvirá testemunhas impedidas ou suspeitas; mas os seus depoimentos serão prestados independentemente de compromisso (art. 415) e o juiz lhes atribuirá o valor que possam merecer."

328 “Art. 530 - Não podem ser eleitos para cargos administrativos ou de representação econômica ou profissional, nem permanecer no exercício desses cargos: [...] II - os que houverem lesado o patrimônio de qualquer entidade sindical; [...] IV - os que tiverem sido condenados por crime doloso enquanto persistirem os efeitos da pena;"

${ }^{329}$ Marcel Del Bianco Cestaro (op. cit., p. 6-8) apontou a desproporcionalidade contida na Lei $\mathrm{n}^{\circ} 7.369$, de 1969, do Município de São Paulo, que veda ao condenado pela prática de qualquer crime doloso inscrever-se no Cadastro Municipal de Empresas de Táxi ou de Condutores de Táxi. 
pregressa do candidato.

A lei complementar brasileira reguladora desse dispositivo atende os critérios da proporcionalidade e da temporariedade. Ela restringe a divulgação dos dados contidos no registro criminal daquele que pretende candidatar-se a cargos públicos eletivos, indicando a natureza dos delitos que deverão constar da certidão relativa a antecedentes para fins eleitorais, e limita a inserção dessa informação ao prazo de três anos após o cumprimento da pena. ${ }^{330,331 \text { e } 332}$

$\mathrm{Na}$ Itália, conforme analisado anteriormente, existe semelhante orientação, embora mais ampla, pois nesse país a informação ofertada pelo registro criminal para finalidades eleitorais abrange condenação e outros provimentos que tenham influência na esfera do direito eleitoral. ${ }^{333}$

O acesso ao registro criminal para fins de fornecer informações necessárias para satisfazer interesses na esfera eleitoral também deve se pautar pela análise da existência de justa causa legitimadora da obtenção dessa informação.

Partidos políticos, órgãos da Justiça e do Ministério Público Eleitoral, por exemplo, ao concederem legenda para disputa de eleições e fiscalizarem os candidatos e ocupantes de cargos para os quais foram eleitos pelo voto popular, devem ter acesso aos dados do registro criminal.

As situações indicadas neste trecho que cuidou do acesso legal para fins diversos foram extraídas de textos nacionais que, embora não tratem, especificamente, de assuntos

\footnotetext{
${ }^{330}$ Lei Complementar $n^{\circ} 64$, de 18 de maio de 1990, estabelece, de acordo com o artigo 14, parágrafo $9^{\circ}$, da Constituição Federal, os casos de inelegibilidade, os prazos de cessação e determina outras providências. A alínea "e" do artigo $1^{\circ}$ dessa lei dispõe que são inelegíveis para qualquer cargo "os que forem condenados criminalmente, com sentença transitada em julgado, pela prática de crimes contra a economia popular, a fé pública, a administração pública, o patrimônio público, o mercado financeiro, pelo tráfico de entorpecentes e por crimes eleitorais, pelo prazo de 3 (três) anos, após o cumprimento da pena."

331 As Normas de Serviço da Corregedoria-Geral da Justiça do Estado de São Paulo (cit.) dispõem no item 54.3 que "das certidões de antecedentes, para fins eleitorais, constarão as distribuições acerca dos delitos elencados no artigo $1^{\circ}$, inc. I, letra "e", da Lei Complementar $n^{\circ} 64 / 90$, bem como observação expressa de que é expedida para fins eleitorais."

332 O Supremo Tribunal Federal, em 6 de agosto de 2008, por maioria, vencidos dois Ministros, julgou improcedente o mérito da argüição referente à Ação de Descumprimento de Preceito Fundamental (ADPF) $n^{\circ}$ 144 em decisão relatada pelo Ministro Celso de Mello. Nesse pedido, ajuizado pela Associação dos Magistrados Brasileiros, foram questionadas as alíneas "d", "e", "g" e "h" do inciso I do artigo $1^{\circ}$ e parte do artigo 15, ambos da Lei Complementar $n^{\circ}$ 64, de 18 de maio de 1990, pretendendo permitir a impugnação do candidato a cargo eletivo que ostentasse condenação criminal a partir da decisão proferida pela Justiça Eleitoral. NOTICIAS STF. Ministro Marco Aurélio vota contra a ação da AMB. Disponível em: $<$ http://www.stf.gov.br/portal/cms/verNoticiaDetalhe.asp?idConteudo=94226\&caixaBu...>. Acesso em: 17 set. 2008.

${ }^{333}$ Ver item 2.6 do Capítulo 2 deste estudo.
} 
criminais, apontam que terceiro interessado, órgãos administrativos e jurisdicionais poderão ter acesso às informações do registro criminal, caso possuírem interesse legítimo em conhecê-las, ou seja, existir previsão legal ou justa causa, pois esse conhecimento não é exclusivo dos órgãos encarregados da persecução penal.

Além disso, esse trecho do estudo demonstra que a anotação inserida no registro ultrapassa a finalidade de comprovar antecedentes criminais e reincidência para fins penais e processuais penais, argumento que valida a defesa da necessidade de manter e aperfeiçoar o registro criminal brasileiro diante do emprego legítimo, diverso e múltiplo que poderá ser feito da informação criminal. 


\section{FUNCIONAMENTO DO REGISTRO E TEMAS CORRELATOS}

\subsection{O funcionamento do registro criminal brasileiro}

No Brasil, em linhas gerais, o registro criminal abrange outras modalidades de arquivos de dados, porque além de compilar as referências relativas ao envolvimento das pessoas com processos criminais e condenações, usualmente, reúne anotações das seguintes áreas:

a) informações policiais, abrangendo a relação das pessoas procuradas pela Justiça;

b) infrações penais de menor potencial ofensivo;

c) processos suspensos;

d) execução penal.

Cada uma dessas áreas é suficientemente complexa para reclamar registros individualizados e independentes, como deveria ocorrer com o registro policial, mas o inter-relacionamento dos conteúdos mostra ser essa reunião adequada, exceto no que concerne aos dados policiais, conforme será debatido adiante.

Neste trecho do estudo, pretende-se analisar o funcionamento do registro criminal a partir da inserção no sistema de dados da informação relativa à investigação policial instaurada para apuração do fato e sua autoria, passando pela anotação da acusação apresentada em relação ao provável autor do crime e acolhida por decisão judicial, além da inscrição das informações geradas na fase da execução penal.

O registro policial merecerá detida análise por ser o embrião do registro criminal e com ele guardar proximidade. Neste ponto do estudo, a rápida abordagem da evolução legislativa do registro policial português servirá para demonstrar avanços e retrocessos pelos quais o instituto passou nesse país, cotejando-os com o estágio do registro policial no Brasil.

O tratamento das anotações referentes aos processos criminais em que o acusado não é citado pessoalmente, exigindo a citação editalícia sem a constituição de defensor ou comparecimento, também será analisado, pois demandará inserir essa informação no registro criminal para facilitar o encontro do acusado e o prosseguimento da ação penal.

Existe necessidade de discutir o registro das infrações penais de menor potencial 
ofensivo especialmente para tornar efetiva a restrição ao acesso da notícia da condenação à pena de multa exclusiva, depois do seu pagamento, exceto para fins de requisição judicial, previstos pela Lei $\mathrm{n}^{\circ} 9.099$, de 1995, na forma adiante exposta.

A pretensão deste capítulo é mostrar o funcionamento do registro criminal e dos sistemas de dados criminais a ele ligados, especialmente porque "não haverá antecedentes, nem a reincidência criminal, se o sistema penal não possuir um banco de dados capaz de informá-lo a respeito". 334

Além disso, será estudado o relacionamento de temas variados ao registro criminal, tais como o rol de culpados, a folha de antecedentes, a reincidência, os antecedentes penais, o interrogatório, os atestados policiais e os cadastros criminais mantidos pelo Ministério Público.

No Brasil, em linhas gerais, reserva-se aos Estados da Federação e ao Distrito Federal a atribuição de criar, manter e atualizar as anotações referentes ao envolvimento das pessoas com crimes, formando o registro criminal. Por isso, antes de tratar dos temas que compõem este capítulo, convém salientar que, pela análise do funcionamento do registro criminal brasileiro, é possível constatar que seus arquivos estão dispersos nas bases de dados estaduais e distrital, criadas e mantidas pelos Institutos de Identificação e Estatística. $^{335}$

Referidos Institutos, criados a partir dos antigos Gabinetes de Identificação e Estatística Criminal e sediados nos diversos Estados da Federação e no Distrito Federal ao longo do século XX, estão ligados, tradicionalmente, à área policial e situam-se no interior da estrutura das pastas estaduais da segurança pública ou justiça. Os Institutos de Identificação e Estatística normalmente se dedicam, entre outros, aos seguintes trabalhos:
a) identificação civil;
b) identificação criminal;
c) estatística criminal;
d) expedição de documentos de identidade, folhas e atestados de antecedentes;
f) cadastro criminal. ${ }^{336}$

\footnotetext{
${ }^{334}$ BISSOLI FILHO, Francisco, op. cit., p. 215.

335 O Código de Processo Penal refere-se ao Instituto de Identificação e Estatística nos seguintes artigos: 23; $166 ; 541$, parágrafo $2^{\circ}$, alínea "b"; 709, caput e parágrafo $1^{\circ} ; 747 ; 809$, caput e parágrafo $3^{\circ}$.

${ }^{336}$ DEPARTAMENTO DE POLÍCIA FEDERAL. Disponível em:

$<$ http://www.dpf.gov.br/homepageIni.html>. Acesso em: 24 novembro 2007.
} 
Ao lado desses Institutos de Identificação e Estatística sediados nos diversos Estados e Distrito Federal, existe o Instituto Nacional de Identificação (INI), instituído pela Lei $\mathrm{n}^{\mathrm{o}} 4.483$, de 16 de setembro de 1963, com a finalidade de coordenar e interligar os serviços de identificação civil e criminal no País. Uma das atribuições do INI é manter intercâmbio de informações criminais com organizações congêneres, nacionais e estrangeiras, ${ }^{337}$ providência alcançada no âmbito interno pela celebração de convênios, em respeito ao modelo federativo brasileiro e à autonomia dos entes federados assegurados pela Constituição Federal.

No Brasil, o Decreto Federal no 6.138, de 28 de junho de 2007, instituiu, no âmbito do Ministério da Justiça, a Rede de Integração Nacional de Informações de Segurança Pública, Justiça e Fiscalização denominada Rede Infoseg. ${ }^{338}$ Por meio dessa rede é facultado aos órgãos competentes realizaram o intercâmbio das informações criminais no País.

$\mathrm{O}$ artigo $8^{\circ}$ do referido decreto federal aponta que a Rede Infoseg sucederá o Programa de Integração de Informações Criminais, enquanto o artigo 12 revoga, expressamente, o Decreto Federal não numerado, de 26 de dezembro de 1995, que institui esse programa.

Entre os fins designados à Rede Infoseg, conforme dispõe o artigo $1^{\circ}$ do Decreto Federal $n^{\circ}$ 6.138, de 2007, está a obrigação de "integrar, nacionalmente, as informações que se relacionam com segurança pública, identificação civil e criminal”. A finalidade que o decreto atribui à rede é "disponibilizar suas informações para a formulação e execução de ações governamentais e de políticas públicas federal, estaduais, distrital e municipais”, podendo dela participar, nos termos do artigo $2^{\circ}$ do mencionado decreto, os órgãos federais da área de segurança pública, controle e fiscalização, as Forças Armadas e os órgãos do Poder Judiciário e do Ministério Público e, mediante convênio, os Estados, o Distrito Federal e os Municípios.

Ao celebrar esse tipo de convênio, os órgãos convenientes ficarão obrigados, dentro das suas atribuições, a gerenciar e atualizar on line os dados respectivos os quais permanecerão disponíveis para consulta na Rede Infoseg cujo acesso é restrito aos usuários credenciados.

\footnotetext{
337 DEPARTAMENTO DE POLÍCIA FEDERAL. Disponível em: <http://www.dpf.gov.br/homepageIni.html>. Acesso em: 24 novembro 2007.

${ }^{338}$ DECRETO FEDERAL No 6.138, de 28 de junho de 2007. Publicações Eletrônicas Associação Paulista do Ministério Público. São Paulo: APMP, 2004-2006. 1 CD-ROM. Produzido por Eduardo Roberto Alcântara Del-Campo e Marinilce Araújo Soria.
} 
O Decreto Federal no 6.138 , de 2007, nos artigos $6^{\circ}$ e $7^{\circ}$, indica também que "o fornecimento de informações de monitoramento e controle da Rede Infoseg e de seus usuários é condicionada à instauração e a instrução de processos administrativos e judiciais" e aponta que "o usuário que se valer indevidamente das informações obtidas por meio da Rede Infoseg está sujeito à responsabilidade administrativa, civil e criminal”.

Os dispositivos constitucionais ${ }^{339}$ e a lei, ${ }^{340}$ invocados para justificar o Decreto Federal $n^{\circ}$ 6.138, de 2007, não mencionam a Lei da Identificação Criminal, ${ }^{341}$ qualquer artigo da legislação penal, processual penal ou de execução penal, apesar de o referido decreto presidencial tratar de assuntos relacionados à legislação citada, como a identificação civil e criminal, os cadastros estaduais de informações criminais, os mandados de prisão expedidos, os processos judiciais e a população carcerária. ${ }^{342}$

Entre as várias leituras que o texto desse decreto permite, uma delas indica que o Ministério da Justiça não visualizou que os textos legais mencionados, uns com mais ênfase e outros menos, tratam dos temas a que o decreto se referiu e, por essa razão, deveriam ser analisados para deles se extraírem subsídios fundamentadores do decreto. Além disso, o decreto pouco se preocupou com o sigilo dos dados armazenados na Infoseg e com a privacidade, desprestigiando a orientação da interpretação dos assuntos nele regulados a partir das garantias constitucionais.

Necessário anotar, ainda, que os registros dos diversos órgãos da justiça criminal, mantidos a partir das informações produzidas pelos juízos criminais, também contribuem

339 “Art. 84 - Compete privativamente ao Presidente da República:

$[\ldots]$

IV - sancionar, promulgar e fazer publicar as leis, bem como expedir decretos e regulamentos para sua fiel execução;

$[\ldots]$

VI - dispor, mediante decreto, sobre:

a) organização e funcionamento da administração federal, quando não implicar aumento de despesa nem criação ou extinção de órgãos públicos;"

${ }^{340}$ Lei n ${ }^{\circ} 10.683$, de 28 de maio de 2003, que dispõe sobre a organização da Presidência da República e dos Ministérios e dá outras providências.

341 A Lei $\mathrm{n}^{\mathrm{o}} 10.054$, de 12 de dezembro de 2000, dispõe sobre a identificação criminal e dá outras providências.

${ }^{342}$ O Conselho Nacional de Justiça (CNJ), órgão do Poder Judiciário, conforme artigo 92, inciso I-A, da Constituição Federal, acrescido pela Emenda Constitucional n ${ }^{\circ} 45$, de 2004, editou a Resolução $n^{\circ} 33$, de 10 de abril de 2007, (Revista A Força Policial, São Paulo: Lene Gráfica, ano 14, n. 56, p. 103-105, out./nov./dez. 2007) que dispõe sobre a criação do Sistema Integrado da População Carcerária no âmbito do Poder Judiciário Nacional.. Referida resolução prevê que o sistema será gerido pelo CNJ, que centralizará as informações sobre pessoas condenadas, a partir dos informes fornecidos pelos órgãos do Poder Judiciário. Entre as várias considerações feitas para justificar a edição da resolução, foi ressaltado que o Poder Judiciário dispõe de informações compartimentadas sobre a população carcerária, as quais são tratadas no âmbito de cada unidade da federação. A atribuição assumida pelo CNJ, apesar das considerações feitas para edição da referida resolução, não é prevista, expressamente, entre aquelas fixadas pelo artigo 103-B, $\S 4^{\circ}$, da Constituição Federal, as quais poderão ser ampliadas pelo Estatuto da Magistratura. 
para a existência do registro criminal, pois neles estão reunidos elementos informativos que permitem expedir certidões comprobatórias do ajuizamento de ações penais e da prolação de decisões criminais condenatórias.

A abordagem que foi feita do assunto registro criminal permite verificar que no Brasil ele é formado e mantido no âmbito do Poder Executivo dos Estados da Federação e Distrito Federal, embora receba contribuição efetiva dos órgãos judiciários criminais, inexistindo legislação federal que trace diretrizes para o seu funcionamento. ${ }^{343}$ Essa ausência dificulta o intercâmbio de informações criminais entre os diversos Institutos de Identificação e Estatística, sem falar em outras dificuldades que podem prejudicar a investigação e a persecução penal, sugerindo ser necessário estruturar o registro criminal no âmbito nacional.

\subsection{Características gerais do registro policial}

$\mathrm{O}$ registro policial, tal qual o registro criminal, foi criado para permitir o conhecimento a respeito do envolvimento criminal das pessoas, tarefa cumprida durante muito tempo pelo primeiro em vários países. ${ }^{344}$

Os dados que formam o registro policial são lastreados na identificação criminal. Essa afirmação é reforçada pelo artigo 32 do Código de Processo Penal Tipo para a IberoAmérica, porque logo depois de tratar da identificação do imputado, a parte final do texto desse artigo recomendou que o procedimento identificatório realizado em relação a alguma pessoa "não implicará seu ingresso num registro penal". 345

Nos países em que a Justiça é informada a respeito dos antecedentes criminais pela polícia, o registro criminal e o policial fundem-se em um só cadastro, não havendo interesse

\footnotetext{
${ }^{343} \mathrm{Na}$ Espanha, sob a ótica administrativa, o registro de antecedentes penais realiza, principalmente, as seguintes funções: a) fornecer aos juízes e tribunais os impressos para anotar as condenações que serão inseridas no registro; b) receber as notas informativas de condenações, classificá-las e arquivá-las, emitindo recibo comprobatório; c) receber os pedidos oficiais de antecedentes e depois de pesquisar os dados, emitir os certificados pertinentes; d) receber as solicitações particulares; e) fazer as eliminações das anotações cabíveis. Em síntese, as operações realizadas podem se resumir em três grandes estágios: a) entrada de documentos; b) tramitação das informações documentais; c) saída de documentos (GROSSO GALVAN, Manuel, op. cit., p. 141-143).

${ }^{344}$ COSTA, António Manuel de Almeida, op. cit., p. 137-138. Cf., também, VEIGA, Catarina, op. cit., p. 56, nota de rodapé $\mathrm{n}^{\mathrm{O}} 75$.

345 GRINOVER, Ada Pellegrini; MOREIRA, José Carlos Barbosa (Colab.). Projeto de Código Processual Penal-Tipo para a Ibero-América. 2a Parte. Revista de Processo, São Paulo, n. 62, p. 176, jan./set. 1991.
} 
em estudar o segundo de modo particular. ${ }^{346}$

Não é essa a realidade nacional, pois o registro criminal brasileiro não depende, exclusivamente, do policial. Embora parte dos dados reunidos no registro criminal resulte das informações inicialmente obtidas pela polícia judiciária, especialmente a partir da instauração de inquéritos policiais, os registros criminal e policial não estão fundidos. Isso se comprova pelo acesso ao conteúdo desses arquivos, visto que tanto a polícia fornece informação e emite atestado a partir dos seus registros como os órgãos judiciários estão aptos a expedir certidões relativas a processos criminais e condenações referentes à determinada pessoa.

Em Portugal, durante considerável parcela de tempo, o registro policial foi uma espécie de duplicata do registro criminal. Esse registro dúplice foi criado e mantido para facilitar o bom desempenho das funções policiais. A polícia, aliás, repetidamente, investiga a autoria de crimes e, ao cumprir essa tarefa, não é incomum que seus agentes associem os criminosos que utilizaram modus operandi parecido aos autores de outros crimes praticadas em circunstâncias semelhantes para iniciarem investigações do delito cuja autoria é incerta. O registro policial autônomo, instrumento para a realização da atividade essencialmente investigativa desenvolvida pela polícia, deveria limitar o fornecimento dessas informações somente ao âmbito interno da corporação. ${ }^{347}$

Ao realizar investigações, é legítimo que a polícia conheça os antecedentes criminais do investigado, embora não se ignore que os agentes policiais, em determinados casos, especialmente naqueles em que as suspeitas da autoria delitiva não recaiam sobre pessoa determinada, empreguem informações extraídas desse banco de dados para selecionar suspeitos que serão investigados para verificar o possível envolvimento deles com o crime sob apuração.

Em Portugal, a existência duplicada do registro policial e criminal fundou-se também na preocupação de defesa da "sociedade contra os ex-condenados" e na utilização do registro policial para elucidar casos de erro de identificação. Apesar de importante ao desempenho da função investigativa, tarefa essa principal, a existência do registro policial possibilitará seja colocado em risco o status dignitatis do cidadão, pois o conhecimento de algumas ocorrências policiais que não correspondam à condenação judicial poderá contribuir para sua estigmatização e facilitar sua pré-seleção como candidato às 
investigações realizadas pela própria polícia, ${ }^{348}$ inclusive porque não é oculto ser "a atuação da Polícia seletiva". 349 e 350

O registro policial, também conhecido como arquivo policial, reúne essas informações que normalmente são cumulativas e amplas, porquanto os dados do envolvimento criminal dos indivíduos, de modo freqüente, são mantidos indefinidamente nesse arquivo, sem cancelamento.

Servir como repositório cumulativo das informações criminais é um dos traços característicos do registro policial, pois normalmente ele conserva os dados recolhidos sem permitir alterações.

$\mathrm{Na}$ Espanha, apesar de existirem normas orientadoras e controladoras do arquivo policial e, também, reguladoras da supressão das informações nele inseridas, afirma-se que cancelar registros policiais é prática, freqüentemente, ignorada pelos corpos policiais e pelos particulares. $^{351}$

$\mathrm{Na}$ Espanha, o arquivo policial é centralizado e fica em Madrid, mas de certo modo está reproduzido na sede das chefaturas regionais de polícia. Seu conteúdo foi considerado como cópia exata do Registro Central de Penados y Rebeldes, embora dotado de características diversas como a maior amplitude dos dados e menor controle da utilização das informações reunidas. O agrupamento das informações pessoais objetivas e dos dados subjetivos das pessoas envolvidas em crimes aumenta o efeito estigmatizante do registro policial no qual se pretende aglutinar o máximo de informação possível para proporcionar eficiência à polícia. Ele serve para facilitar a busca inicial dos autores de determinado crime entre aqueles que possuem antecedentes policiais. Investigar a partir dos antecedentes, sejam criminais ou policiais, é "base insubstituível da mecânica policial”. Os antecedentes penais do investigado também se somam ao arquivo policial, tratando-se de importante parte das informações nele reunidas. ${ }^{352}$

Ainda na Espanha é possível cancelar as informações reunidas no arquivo policial, diferindo o procedimento a ser adotado caso o sujeito possua ou não antecedentes penais.

\footnotetext{
${ }^{348}$ COSTA, António Manuel de Almeida, op. cit., p. 140.

${ }^{349}$ GROSSO GALVAN, Manuel, op. cit., p. 191-196.

${ }^{350}$ BISSOLI FILHO, Francisco, op. cit, p. 174, nota de rodapé 93. Em outro trecho do texto (p. 180), depois de analisar a posição de alguns estudiosos, o autor afirma que "a lógica que orienta o funcionamento do sistema penal é a diferenciação ou seleção de pessoas", arrematando, mais adiante (p. 188), com a seguinte afirmação: "Estudos feitos demonstram que as forças policiais concentram as suas atenções e suas atividades de prevenção e repressão sobre certos grupos que foram anteriormente identificados por meio de etiquetas. (A folha de antecedentes policiais e penais representa aqui um importante papel)."

${ }^{351}$ GROSSO GALVAN, Manuel, op. cit., p. 23.

${ }^{352}$ Id., ibid., op. cit., p. 186-191.
} 
Se possuí-los, o interessado deverá alcançar primeiro o cancelamento dos antecedentes penais e depois requerer o cancelamento dos dados correspondentes anotados no arquivo policial. Considera-se injustificável, aliás, não refletir automaticamente o cancelamento do registro criminal na anotação correspondente do arquivo policial. Se o indivíduo não possuir antecedentes, porque na Espanha se anotam os antecedentes criminais a partir do trânsito em julgado da decisão condenatória, o cancelamento dos antecedentes policiais exigirá apresentação do documento indicativo da não-responsabilização penal do interessado (por exempo, prova da absolvição). Deferido o cancelamento da anotação do arquivo policial, o respectivo registro não será eliminado, o que transforma o cancelamento em vedação de certificar sobre a anotação cancelada, traduzindo-se na prática na manutenção no arquivo das anotações da pessoa que não cometeu delito e até pode ter sido apontada como seu autor por equívoco policial e permitindo, inclusive, seja seu nome colocado entre os suspeitos em potencial da prática dos crimes a investigar. ${ }^{353}$

Registro policial é assunto que gera diversos conflitos, os quais devem ser dirimidos, pois ao mesmo tempo que é considerado importante para a tarefa de investigação, tanto que é comum afirmar estar "a eficácia policial baseada na eficácia dos seus arquivos", seu emprego também pode colocar o particular em risco. O maior conflito produto do uso do registro policial é o emprego dos seus dados para selecionar prováveis criminosos e descobrir eventuais crimes, atividade conhecida como "etiquetamento" ou, pior ainda, gerar, artificialmente, a criminalidade e os criminosos. ${ }^{354}$

Ao tratar dos registros policiais e criminais, José Laércio Araújo afirma que o legislador deveria se encaminhar no sentido de excluir anotações inseridas no registro de antecedentes criminais e "arquivos paralelos". O autor considera como "arquivos paralelos" os cadastros mantidos pelas delegacias de polícia especializadas para "consulta interna" e "externa", servindo para transformá-las em "verdadeiros órgãos paralelos de informação". Ele usa como argumento para sustentar sua opinião os mandamentos do artigo $5^{\circ}$, inciso XII, da Constituição Federal e indica que essa forma de uso das informações dos registros ofende a imagem e a intimidade do indivíduo. ${ }^{355}$

José Laércio Araújo trata, ao mesmo tempo, temas diferentes, porque aborda o registro criminal e policial, possivelmente, diante da ligação umbilical desses assuntos. Entretanto se destacam na opinião do autor as referências à irregularidade de determinadas

\footnotetext{
${ }^{353}$ GROSSO GALVAN, Manuel, op. cit., p. 192-196.

${ }^{354}$ Id., ibid., p. 363-367.

${ }^{355}$ Intimidade, vida privada e direito penal. São Paulo: Habeas [s.d.] p. 119-121.
} 
consultas aos registros policiais, à criação de "arquivos paralelos" e, principalmente, ao uso indevido dos dados reunidos nesses arquivos com ofensa à pessoa, tema abordado nesta tese.

Outro problema que acompanha o registro policial é a dificuldade da criação de mecanismos legislativos adequados ao seu controle. ${ }^{356}$ Deveria existir disposição legal que indicasse ser o seu conteúdo de uso exclusivo da polícia e estabelecesse, de modo expresso, sanções aos funcionários que descuidassem dessa regra elementar. Esses cuidados serviriam para desestimular o risco da divulgação indevida dessas informações.

Regular por lei o registro policial no Brasil é idéia que deve ser debatida juntamente com eventuais propostas legislativas de regulação do registro criminal, exigindo análise de temas como a regulação do conteúdo e do acesso.

Cumpre acrescentar, ainda, que as informações relativas às pessoas procuradas e que se evadiram das prisões, alimentadoras do cadastro dos procurados, devem ser fornecidas ao registro policial e criminal pela necessidade dessa situação ser conhecida pela justiça, polícia e demais órgãos ligados à persecução penal. Esse cadastro de pessoas procuradas, desde que destacado do registro criminal e policial, deve ser público, inclusive porque "a recaptura do réu evadido não depende de prévia ordem judicial e poderá ser efetuada por qualquer pessoa". 357

Outro assunto correlato ao registro policial que exige atenção especialmente em virtude do risco de afrontar a privacidade é a questão de a polícia emitir atestados relacionados com a existência de inquéritos policiais a partir da consulta aos seus arquivos.

$\mathrm{O}$ atestado de antecedentes, expedido pela autoridade policial na forma do artigo 20, parágrafo único, do Código de Processo Penal, ${ }^{358}$ assemelha-se ao antigo certificado de buena conducta espanhol, mais recentemente denominado informe de conducta ciudadana, regulado pela Ley de 1 de diciembre de 1980 que dispõe sobre a certificação dos antecedentes penais pela polícia espanhola. O informe de conducta ciudadana, portanto, é uma espécie de certificado penal amplo no qual são anotados quaisquer envolvimentos

\footnotetext{
${ }^{356}$ COSTA, António Manuel de Almeida, op. cit., p. 141.

357 Art. 684 do Código de Processo Penal.

358 “Art. 20 - A autoridade assegurará no inquérito o sigilo necessário à elucidação do fato ou exigido pelo interesse da sociedade.

Parágrafo único. Nos atestados de antecedentes que lhe forem solicitados, a autoridade policial não poderá mencionar quaisquer anotações referentes a instauração de inquérito contra os requerentes, salvo no caso de existir condenação anterior.

* Parágrafo acrescentado pela Lei n ${ }^{\circ} 6.900$, de 14 de abril de 1981.”
} 
criminais da pessoa. ${ }^{359}$

O tema referente aos atestados fornecidos pela polícia liga-se ao sigilo dos dados do inquérito policial, pois nesse documento a polícia exterioriza a notícia dos inquéritos policiais nos quais o investigado foi indiciado. A partir do indiciamento, o nome do investigado constará dos arquivos policiais e será inscrito nos atestados de antecedentes expedidos a pedido do próprio interessado e nas informações fornecidas à polícia e ao juiz. $\mathrm{O}$ indiciamento e sua divulgação por meio de atestado "constitui pecha, que traz conseqüências nefastas de toda a ordem”, porque já se afirmou que propostas de emprego ou negociações imobiliárias podem ser desfeitas a partir do conhecimento do conteúdo de atestado de antecedentes policiais. ${ }^{360}$

Ao final, nota-se que o registro policial deve ser visto e pensado como instrumento colocado à disposição da polícia para o exercício da atividade investigativa. Seu conteúdo deve exibir, entre outras informações, as condenações decretadas pela Justiça e os dados acerca dos mandados de captura passíveis de cumprimento. ${ }^{361} \mathrm{O}$ acesso ao seu conteúdo, por meio de atestados, deve ser feito de modo a proteger a privacidade da pessoa e obedecer aos estritos limites traçados pela regra inserida no parágrafo único do artigo 20 do Código de Processo Penal.

\subsection{Notas sobre a evolução do registro policial português}

Em Portugal, o registro policial surgiu a partir de um Decreto, de 25 de maio 1825, que criou uma secretaria para regular o controle da expedição de passaportes e o respectivo registro. Nesse país, à época, era exigido o passaporte para todas as pessoas que desejassem se afastar por mais de cinco léguas do local do domicílio, exceto para os militares que obedeciam a regras específicas. A adoção desse sistema rigoroso tinha por objetivo reduzir a movimentação das pessoas e outorgar à autoridade, pelo menos de modo teórico, o controle total da circulação delas no interior do território. Ao ser criado, o registro policial português estava fundado, basicamente, na idéia de defesa da sociedade, tanto que abrangia não apenas os condenados e pronunciados, mas também as pessoas consideradas suspeitas

\footnotetext{
${ }^{359}$ GROSSO GALVAN, Manuel, op. cit., p. 197.

${ }^{360}$ PEREIRA, Flávia Rahal Bresser. A publicidade no processo penal brasileiro. Confronto com o direito à intimidade. Dissertação (Mestrado em Processo Penal) - Faculdade de Direito do Largo de São Francisco, São Paulo, 2000. p. 206-209.

${ }^{361}$ COSTA, António Manuel de Almeida, op. cit., p. 142, em especial, nota de rodapé 235.
} 
e, em relação aos não condenados inexistia previsão de meios para apagar as anotações de mera suspeita. $^{362}$

O registro policial português, no período entre o final do século XVIII e o início do século seguinte, embora estabelecido e desenvolvido para atender fins da prevenção especial, acabou utilizado como instrumento de "política extremista", porque passou a abranger "além dos condenados e pronunciados, os próprios suspeitos". ${ }^{363}$ Essa constatação extraída da experiência portuguesa serve como advertência e orientação para análise de eventuais propostas reguladoras do registro policial no Brasil, ao conduzir ao debate sobre a natureza e a qualidade das informações que deverão compor esse registro cujo arquivo não pode ser discriminatório e deverá, integralmente, respeitar valores constitucionais.

Ainda em Portugal, Decretos editados em 1893 e 1894, de certa forma, alteraram o registro policial, pois, em especial, permitiram que nos casos de absolvição o cadastro seria inutilizado por ordem do juiz, identicamente ao que deveria ocorrer nos casos de morte ou reabilitação. Entretanto, se em algum aspecto é possível observar evolução, houve evidente retrocesso e ampliação do caráter estigmatizante e discriminatório do registro policial nesse país, porque na época se tolerava nele anotar, sempre que houvesse interesse indicado pelo juiz, os vícios, os costumes e até as doenças, não só dos presos, bem como dos seus familiares. A exteriorização dos dados constantes do registro passou a ser feita por intermédio de certidões expedidas às autoridades públicas, ao próprio titular e aos terceiros interessados, devendo estes demonstrar que o pedido era conveniente por meio de documentos ou testemunhas. No mesmo período, o registro criminal já existia e, em relação aos terceiros, as certidões dos dados nele inseridos eram concedidas se houvesse fundamentação do pedido e demonstração do justo motivo perante o Ministério Público. ${ }^{364}$

A finalidade do registro policial, desde a sua instituição, era servir como instrumento para a realização da atividade investigativa da polícia, enquanto $o$ fornecimento dos dados aos terceiros interessados configurou uma espécie de anomalia lastreada pelo cumprimento da tarefa de defesa social. ${ }^{365}$

É interessante imaginar a redução do âmbito de utilização do arquivo policial, ao condicioná-lo a órgão informativo interno da Polícia, eliminando a possibilidade do acesso aos particulares pela emissão dos atestados ou certidões. Restringir o emprego da

\footnotetext{
${ }^{362}$ COSTA, António Manuel de Almeida, op. cit., p. 143-144.

${ }^{363}$ VEIGA, Catarina, op. cit., p. 56, nota de rodapé 75.

${ }^{364}$ COSTA, António Manuel de Almeida, op. cit., p. 145-146.

${ }^{365}$ Id., ibid., p. 147.
} 
informação produzida, registrada e mantida no arquivo policial para uso interno não reduz ou neutraliza a importância do registro policial, mas permite a fixação de limite ao uso o qual não deveria ter sido ultrapassado. ${ }^{366}$

Retomando a análise evolutiva do registro policial no território lusitano, observa-se que o Decreto $\mathrm{n}^{\mathrm{o}} 14.731$, de 15 de dezembro de 1927, foi o último texto que atualizou a regulamentação do registro policial nesse país, editado antes da sua unificação ao registro criminal em dezembro de 1936. Esse decreto lhe alterou a organização e o acesso ao conteúdo, pois, a partir de 1927, o registro policial organizou-se alicerçado em critério de domicílio, isto é, foi repartido pelo país com base em ficheiros locais e também autorizou a expedição de duas modalidades de certificados, ou seja, integrais e parciais quanto ao conteúdo do registro policial. A partir dessa regulamentação, permitiu-se expedir certificados integrais para atender os magistrados judiciais e do Ministério Público, à polícia e às autoridades administrativas que exercessem funções semelhantes àquelas desempenhadas pelos juízes. Para atendimento das demais solicitações eram expedidos certificados parciais, nos quais as detenções que não fossem seguidas de condenações deveriam ser omitidas, bem como aquelas ocorridas depois de determinado espaço de tempo, assemelhando-se ao regramento que já existia em relação ao registro criminal. ${ }^{367}$

Após a unificação ao registro criminal ocorrida em dezembro de 1936, o registro policial português retornou a cumprir a finalidade orientadora da sua criação, ou seja, servir como subsídio para guiar as funções investigativas da polícia. $\mathrm{O}$ acesso particular aos seus dados foi vedado, impedindo-se a terceiros e entidades públicas, exceto nos casos excepcionados por lei, o fornecimento de informações, enquanto este passou a ser tarefa do registro criminal.

Em Portugal, pela regra do Decreto-Lei 39/83, de 25 de Janeiro, não eram incluídas no registro policial as condenações proferidas pelos tribunais, pois caso necessário a polícia conseguiria essa informação mediante acesso ao registro criminal, ${ }^{368}$ situação que parece mantida a partir da entrada em vigor da Lei 57/98, de 18 de Agosto.

É importante visualizar a evolução do registro policial português, especialmente conhecer os seus percalços, a partir do retrocesso resultante da ampliação ao acesso particular e distante do atendimento das necessidades investigativas próprias da polícia para as quais foi criado. Verificar, também, que é preciso condicioná-lo ao fim para o qual foi

\footnotetext{
${ }^{366}$ GROSSO GALVAN, Manuel, op. cit., p 198.

${ }^{367}$ COSTA, António Manuel de Almeida, op. cit., p. 148.

${ }^{368}$ VEIGA, Catarina, op. cit., p. 57, nota de rodapé 75.
} 
instituído e constatar a multiplicidade de textos que regularam o assunto ao longo de quase duzentos anos em Portugal, deve despertar o legislador nacional para o debate do tema.

A precariedade da regulação do registro policial no território nacional leva os responsáveis pelo gerenciamento desse sistema de dados criminais adotar providências peculiares para cumprir determinação judicial referente ao cancelamento de dados do registro. Exemplo disso é o que ocorre no Estado de São Paulo, porque entre os cadastros criminais mantidos pelo Instituto de Identificação Ricardo Gumbleton Daunt de São Paulo (IIRGD) existem anotações colocadas "em caráter reservado, o que impede o seu acesso por unidades policiais". 369

O respeito à privacidade do indivíduo e a eficiência esperada dos órgãos públicos, entre eles a polícia, devem nortear a regulação e a interpretação dos temas relacionados ao registro policial brasileiro, que deve estruturar-se e voltar-se à sua finalidade peculiar, ou seja, fornecer dados necessários à investigação de crimes a ser realizada pelos órgãos competentes.

\subsection{Cadastros criminais mantidos pelo Ministério Público}

O Ministério Público deve ter acesso aos dados do registro criminal e policial relativos às pessoas processadas e investigadas com a mesma possibilidade que têm os juízes, os tribunais e a polícia de conhecer essas informações.

Referido acesso deve estar condicionado ao exame dos antecedentes criminais das pessoas acusadas ou investigadas em procedimento determinado e apuratório de crime. ${ }^{370}$

A regulamentação do acesso ao registro criminal pelo órgão do Ministério Público no Brasil pode ser extraída da previsão contida no parágrafo $2^{\circ}$ do artigo 163 da Lei $n^{\circ}$ 7.210, de 1984, que trata da execução penal. ${ }^{371}$ Essa norma, que cuida do registro sigiloso

\footnotetext{
${ }^{369}$ O trecho colocado entre aspas consta do Mandado de Segurança $n^{\circ}$ 438.372.3/7 (BRASIL. Tribunal de Justiça. Relator: Hélio de Freitas, da $4^{\text {a }}$ Câmara Criminal, São Paulo, SP, 30 de março de 2004. Disponível em:

$<$ http://cjo.tj.sp.gov.br/esaj/cpo/sg/show.do?processo.foro+990\&processo.codigo=RL00CQYF0000\&cdForo $=1 \&$ baseIndice=INDSG $>$. Acesso em: 20 set. 2008). No corpo do acórdão foi transcrita comunicação enviada ao tribunal pelo Delegado de Polícia, encarregado do IIRGD, na qual descreve o procedimento adotado pelo órgão em relação ao tratamento de determinados dados contidos no cadastro criminal.

${ }_{370}^{370}$ GROSSO GALVAN, Manuel, op. cit., p 214.

371 “Art. 163 - A sentença condenatória será registrada, com a nota de suspensão, em livro especial do juízo a que couber a execução da pena.

$\S 1^{\circ}$. Revogada a suspensão ou extinta a pena, será o fato averbado à margem do registro.

$\S 2^{\circ}$. O registro e a averbação serão sigilosos, salvo para efeito de informações requisitadas por órgãos
} 
da suspensão condicional da pena, nesse aspecto complementou a regra trazida pelo parágrafo $2^{\circ}$ do artigo 709 do Código de Processo Penal. ${ }^{372}$

Em Portugal, o acesso do Ministério Público aos dados da identificação e, por conseqüência, ao registro criminal, decorre de expresso dispositivo inserido na alínea "a" do $\operatorname{artigo} 7^{\circ}$ da Lei $57 / 98$, de 18 de Agosto. ${ }^{373}$

Sob outro ângulo, também não é possível vedar ao Ministério Público, no exercício das suas funções institucionais, criar e manter cadastros contendo dados relativos às pessoas investigadas e acusadas em razão do conhecimento que o órgão detiver do envolvimento criminal dessas pessoas. Esse cadastro, entretanto, deve servir, exclusivamente, ao uso interno dos membros da instituição. As informações nele contidas poderão ser utilizadas, excepcionalmente, à semelhança dos dados extraídos do registro criminal para comprovar os antecedentes criminais da pessoa cadastrada em determinadas situações que adiante serão referidas.

O cadastro criminal que o Ministério Público pode manter, portanto, é sigiloso e reúne informações criminais, não se tratando de arquivo geral criminal, mas espécie de extrato sistêmico e classificado das informações criminais que poderão ser empregadas para o correto exercício das funções institucionais. Esse cadastro deve ser usado com respeito à privacidade da pessoa, razão pela qual não deve franquear acesso a terceiros, somente aos próprios interessados e aos órgãos judiciários se houver necessidade demonstrada de alterar ou corrigir dados incorretos com a finalidade de preservar a privacidade.

Sua manutenção e funcionamento devem seguir, em linhas gerais, a regulamentação fixada ao registro policial, pois sua função a ele se assemelha. Enquanto o registro policial contribui na tarefa investigativa desenvolvida, peculiarmente, pela polícia, o cadastro criminal elaborado e mantido pelo Ministério Público pretende auxiliar o membro dessa instituição, essencialmente, ao promover a ação penal pública, na forma da lei, missão

judiciário ou pelo Ministério Público, para instruir processo penal.”

372 "Art. 709 - A condenação será inscrita, com a nota de suspensão, em livros especiais do Instituto de Identificação e Estatística, ou repartição congênere, averbando-se, mediante comunicação do juiz ou do tribunal, a revogação da suspensão ou a extinção da pena. Em caso de revogação, será feita a averbação definitiva no registro geral.

$\S 1^{\circ}$. Nos lugares onde não houver Instituto de Identificação e Estatística ou repartição congênere, o registro e a averbação serão feitos em livro próprio no juízo ou no tribunal.

$\S 2^{\circ}$. O registro será secreto, salvo para efeito de informações requisitadas por autoridade judiciária, no caso de novo processo.

$\S 3^{\circ}$. Não se aplicará o disposto no $\S 2^{\circ}$, quando houver sido imposta ou resultar de condenação pena acessória consistente em interdição de direitos.”

${ }^{373}$ VEIGA, Catarina, op. cit., p. 148. 
constitucional e privativa atribuída à instituição pela Constituição Federal. ${ }^{374}$

Esse cadastro poderá reunir, por exemplo, informações relativas ao infrator e ao crime investigado, bem como outros dados importantes, tais como:

a) dados variados acerca da identificação pessoal;

b) natureza, local e horário da prática criminosa;

c) nome dos policiais responsáveis pela investigação;

d) indicação dos nomes de outros agentes que se associaram para o cometimento do crime;

e) peculiaridades relativas ao cometimento do crime;

f) decretação de prisão preventiva, temporária ou outra medida restritiva eventualmente imposta;

g) data, local e período da prisão;

h) números atribuídos à investigação policial, processo criminal e processo de execução penal;

i) nome da vítima e das eventuais testemunhas.

Os dados mencionados a título de exemplo, além de outros que poderão ser acrescidos, serão empregados para otimizar o exercício funcional, mas se necessário, poderão servir como meio facilitador da obtenção de certidões criminais relativas às condenações que, por motivos variados, não constem das informações oficiais fornecidas pelo registro criminal.

Exatamente para suprir deficiências informativas do registro criminal foi referido que na Espanha se permitiu à Fiscalía del Tribunal Supremo, com base no que dispunha o artigo 397 da Ley de Enjuiciamiento Criminal, utilizar dados recolhidos por outros registros, referindo-se no caso aos registros mantidos por juízes e tribunais, principalmente quando houver demonstração de divergência entre os dados do registro central e registros parciais, ou quando apresentarem informações incompletas. Isso foi admitido, frisa-se, como providência complementar e excepcional, pois nesse país os antecedentes penais devem ser pedidos exclusivamente ao Registro Central de Penados y Rebeldes. ${ }^{375}$

Essa situação permite fundamentar o entendimento de que ao órgão do Ministério

${ }^{374}$ Art. 129, inciso I.

${ }^{375}$ GROSSO GALVAN, Manuel, op. cit., p 28. 
Público é facultado usar os dados contidos no cadastro criminal que a instituição pode manter para, excepcionalmente, comprovar a existência de antecedentes criminais, caso o acesso regular ao registro criminal não permita fazê-lo.

É necessário assegurar ao Ministério Público, ao promover ação penal na forma da lei, tarefa que lhe é reservada pela Constituição Federal, o acesso aos dados do registro criminal, independentemente, da autorização judicial, sem restrições do responsável pelo gerenciamento dessas informações criminais. Não deve ser obstado ao órgão, também, manter arquivos criminais próprios disponíveis, normalmente, ao uso interno, mas facultado o emprego para comprovação de antecedentes se tais dados inexistirem ou forem omitidos pelo registro criminal.

\subsection{Infração penal de menor potencial ofensivo e registro criminal}

A expressão "infração penal de menor potencial ofensivo", inserida no ordenamento jurídico nacional a partir da entrada em vigor da Constituição Federal em 5 de outubro de $1988,{ }^{376}$ está definida para os efeitos da aplicação da Lei $n^{0} 9.099$, de 1995, Lei dos Juizados Especiais Cíveis e Criminais, como "as contravenções penais e os crimes a que a lei comine pena máxima não superior a 2 (dois) anos, cumulada ou não com multa". ${ }^{377}$

A partir da edição da Lei $\mathrm{n}^{0} 9.099$, de 1995, outros textos legislativos permitiram a aplicação, cada qual com suas peculiaridades e limitações, do acordo civil, da transação penal, da representação ou da suspensão condicional do processo, ${ }^{378}$ medidas despenalizadoras definidas e tratadas pelos artigos $74,75,76$ e 89 , todos da referida lei.

\footnotetext{
376 “Art. 98 - A União, no Distrito Federal e nos Territórios, e os Estados criarão:

I - juizados especiais, providos por juízes togados, ou togados e leigos, competentes para a conciliação, o julgamento e a execução de causas cíveis de menor complexidade e infrações penais de menor potencial ofensivo, mediante os procedimentos oral e sumaríssimo, permitidos, nas hipóteses previstas em lei, a transação e o julgamento de recursos por turmas de juízes de primeiro grau;"

377 "Art. 61 - Consideram-se infrações penais de menor potencial ofensivo, para os efeitos desta Lei, as contravenções penais e os crimes a que a lei comine pena máxima não superior a 2 (dois) anos, cumulada ou não com multa.

Artigo com redação determinada pela Lei 11.313/2006.

$[\ldots]$

Art. 84 - Aplicada exclusivamente pena de multa, seu cumprimento far-se-á mediante pagamento na Secretaria do Juizado.

Parágrafo único - Efetuado o pagamento, o Juiz declarará extinta a punibilidade determinando que a condenação não fique constando dos registros criminais, exceto para fins de requisição judicial."

${ }^{378} \mathrm{O}$ registro criminal conterá anotações dos processos nos quais foi concedida suspensão condicional do processo, porque essa medida deverá ser revogada obrigatoriamente se no curso do prazo for processado por outro crime ou, facultativamente, se processado por contravenção penal.
} 
Os textos legislativos nacionais, a seguir indicados, trataram da infração de menor potencial ofensivo, do emprego das medidas despenalizadoras ou do procedimento definido na Lei $\mathrm{n}^{\circ}$ 9.099, de 1995:

a) o Código de Trânsito brasileiro, Lei no 9.503, de 1997, permitiu fossem essas medidas aplicadas a determinados crimes; ${ }^{379}$

b) a legislação que definiu condutas e atividades lesivas ao meio ambiente, Lei $n^{0}$ 9.605, de 1998, autorizou aplicar a transação penal e a suspensão condicional do processo às infrações de menor potencial ofensivo, se realizada ou projetada a reparação do dano ambiental; 380

c) o Estatuto do Idoso, Lei $\mathrm{n}^{\mathrm{o}} 10.741$, de 2003, permitiu aplicar o procedimento previsto na Lei $n^{\circ} 9.099$, de $1995 .^{381}$

Além desses dispositivos, a Lei $\mathrm{n}^{\mathrm{o}} 11.719$, de 20 de julho de 2008 , que alterou o

\footnotetext{
379 “Art. 291 - Aos crimes cometidos na direção de veículos automotores, previstos neste Código, aplicam-se as normas gerais do Código Penal e do Código de Processo Penal, se este Capítulo não dispuser de modo diverso, bem como a Lei $\mathrm{n}^{\circ} 9.099$, de 26 de setembro de 1995, no que couber.

$\S 1^{\circ}$ Aplica-se aos crimes de trânsito de lesão corporal culposa o disposto nos arts. 74, 76 e 88 da Lei $n^{\circ}$ 9.099, de 26 de setembro de 1995, exceto se o agente estiver:

I - sob a influência de álcool ou qualquer outra substância psicoativa que determina dependência;

II - participando, em via pública, de corrida, disputa ou competição automobilística de exibição ou demonstração de perícia em manobra de veículo automotor, não autorizada pela autoridade competente;

III - transitando em velocidade superior à máxima permitida para a via em $50 \mathrm{~km} / \mathrm{h}$ (cinqüenta quilômetros por hora).

$\S 2^{\circ}$ Nas hipótese previstas no $\S 1^{\circ}$ deste artigo deverá ser instaurado inquérito policial para a investigação da infração."

Artigo com redação alterada pela Lei 11.705 , de 19 de junho de 2008.

380 "Art. 27 - Nos crimes ambientais de menor potencial ofensivo, a proposta de aplicação imediata de pena restritiva de direitos ou multa, prevista no art. 76 da Lei n ${ }^{\circ} 9.099$, de 26 de setembro de 1995, somente poderá ser formulada desde que tenha havido a prévia composição do dano ambiental, de que trata o art. 74 da mesma lei, salvo em caso de comprovada impossibilidade.

Art. 28 - As disposições do art. 89 da Lei no 9.099, de 26 de setembro de 1995, aplicam-se aos crimes de menor potencial ofensivo definidos nesta Lei, com as seguintes modificações:

I - a declaração de extinção de punibilidade, de que trata o $\S 5^{\circ}$ do artigo referido no caput, dependerá de laudo de constatação de reparação do dano ambiental, ressalvada a impossibilidade prevista no inciso I do $\S$ $1^{\circ}$ do mesmo artigo;

II - na hipótese de o laudo de constatação comprovar não ter sido completa a reparação, o prazo de suspensão do processo será prorrogado, até o período máximo previsto no artigo referido no caput, acrescido de mais um ano, com suspensão do prazo da prescrição;

III - no período de prorrogação, não se aplicarão as condições dos incisos II, III e IV do $\S 1^{\circ}$ do artigo mencionado no caput;

IV - findo o prazo de prorrogação, proceder-se-á à lavratura de novo laudo de constatação de reparação do dano ambiental, podendo, conforme seu resultado, ser novamente prorrogado o período de suspensão, até o máximo previsto no inciso II deste artigo, observado o disposto no inciso III;

V - esgotado o prazo máximo de prorrogação, a declaração de extinção de punibilidade dependerá de laudo de constatação que comprove ter o acusado tomado as providências necessárias à reparação integral do dano."

381 “Art. 94. Aos crimes previstos nesta Lei, cuja pena máxima privativa de liberdade não ultrapasse 4 (quatro) anos, aplica-se o procedimento previsto na Lei $\mathrm{n}^{\circ}$ 9.099, de 26 de setembro de 1995, e, subsidiariamente, no que couber, as disposições do Código Penal e do Código de Processo Penal."
} 
Código de Processo Penal, dispôs no parágrafo primeiro do artigo 394 que o "procedimento será comum e especial" (inciso I), enquanto o "procedimento comum será ordinário, sumário ou sumaríssimo" (inciso II), reservando o sumaríssimo para "as infrações penais de menor potencial ofensivo, na forma da lei” (inciso III).

A partir dessas observações serão feitas considerações acerca das infrações penais de menor potencial ofensivo e do registro criminal, especificamente em relação à transação penal e à sentença condenatória com imposição do pagamento exclusivo de multa em virtude do tratamento "levemente diferenciado" dispensado ao registro criminal pela Lei $\mathrm{n}^{\circ}$ 9.099, de $1995 .^{382}$

Inicialmente, admite-se anotar no registro policial e criminal os dados que forem obtidos a partir da lavratura do termo circunstanciado, referido no caput do artigo 69 da Lei $\mathrm{n}^{\circ}$ 9.099, de 1995 . $^{383}$ Citadas informações são anotadas, mesmo sem determinação legal específica para sua realização, "a título de controle administrativo, entretanto sem qualquer conotação penal até aquele momento", 384 mediante aplicação subsidiária da regra do artigo 23 do Código de Processo Penal, permitida pelo artigo 92 da Lei $n^{\circ}$ 9.099, de 1995, pois se ao remeter o inquérito policial ao juízo a autoridade policial comunica ao Instituto de Identificação ou repartição congênere, ao enviar o termo circunstanciado deve adotar idêntica providência. Mencionada anotação é sigilosa para preservação da privacidade do autor do fato e da vítima, estando acessível somente mediante requisição judicial ou do órgão ministerial.

A transação penal, ${ }^{385}$ por se tratar de medida despenalizadora sem efeito condenatório, que "não importará em reincidência" e "não constará de certidão de antecedentes criminais", também merecerá registro. Embora a anotação seja feita no próprio registro criminal, deverá ser inserida em campo específico nele desenvolvido, no qual também deve ser anotada a notícia da existência do termo circunstanciado, guardando independência em relação a outras anotações referentes a inquéritos policiais, processos criminais e de execução penal, por exemplo. Esse registro deverá, sobretudo, ser preservado

${ }^{382}$ MACHADO, Daniel Felipe. Registro Criminal e o Juizado Especial. Revista dos Juizados Especiais. Brasília, Tribunal de Justiça do Distrito Federal e dos Territórios, n. VIII, p. 18, jan./jun. 2000.

383 "Art. 69 - A autoridade policial que tomar conhecimento da ocorrência lavrará termo circunstanciado e o encaminhará imediatamente ao Juizado, com o autor do fato e a vítima, providenciando-se as requisições dos exames periciais necessários."

${ }^{384}$ MACHADO, Daniel Felipe, op. cit., loc. cit.

385 Transação penal pode ser considerada como a proposta antecipada de aplicação de pena restritiva de direitos ou multa apresentada pelo Ministério Público ao autor da infração e seu defensor, no caso do cometimento de infração penal de menor potencial ofensivo, desde que ausentes as hipóteses tratadas pelo parágrafo $2^{\circ}$ do artigo 76 da Lei no 9.099, de 1995. 
pelo sigilo para proteger a privacidade da pessoa.

A anotação relacionada à aceitação da transação penal é automática, seguindo a regra do automatismo do registro criminal, ou seja, é realizada independentemente de determinação judicial específica.

O acesso ao conteúdo da anotação referente à transação penal, inserida no citado campo especialmente desenvolvido do registro criminal, deve ser permitido apenas para atender as requisições judiciais ou do Ministério Público, ou seja, para vedar proposta de transação em favor da pessoa que recebeu outra ou, nos exatos termos do inciso II do parágrafo $2^{\circ}$ do artigo 76 da Lei $\mathrm{n}^{\circ}$ 9.099, de 1995, impedir o gozo ao "ter sido o agente beneficiado anteriormente, no prazo de 5 (cinco) anos, pela aplicação de pena restritiva ou multa". 386

A transação penal celebrada em razão da prática de infração penal de menor potencial ofensivo, abrangida pelo artigo 76 da Lei $\mathrm{n}^{\circ}$ 9.099, de 1995, e aceita em virtude de indicação especialmente outorgada pelas leis antes indicadas (Código de Trânsito brasileiro, condutas e atividades lesivas ao meio ambiente e Estatuto do Idoso), também será anotada no registro criminal automaticamente.

A anotação estará acessível para atender a requisição judicial ou do Ministério Público para fins de impedir a repetição da medida despenalizadora antes de ultrapassado o prazo de 5 (cinco) anos e, ${ }^{387}$ ainda, não deverá constar das certidões judiciais ou atestados de antecedentes policiais expedidos.

Aquele que aceitou transação penal poderá requerer em seu nome certidão para "fins civis ou funcionais", mas nela não "constará a incidência delituosa dirimida pela transação penal e com a conseqüente extinção da punibilidade pelo seu cumprimento". 388

É importante fazer uma pausa para citar duas situações diferenciadas, previstas na Lei $n^{\circ} 9.099$, de 1995, relacionadas aos casos em que a lei exige representação para apurar a infração penal de menor potencial ofensivo ou permitir celebrar acordo civil que resulte na

\footnotetext{
${ }^{386}$ Conforme dispõem os parágrafos $2^{\circ}$, inciso II, $4^{\circ}$ e $6^{\circ}$, todos da Lei $n^{\circ} 9.099$, de 1995.

${ }^{387} \mathrm{O}$ extinto Tribunal de Alçada Criminal de São Paulo considerou inexistir direito líquido e certo e indeferiu pedido formulado em mandado de segurança ajuizado por pessoa beneficiada pela Lei $n^{\circ}$ 9.099, 1995, que buscava o cancelado de anotação feita em seu nome no distribuidor criminal e no Instituto de Identificação do Estado. Segundo esse julgado, no caso de transação penal, a própria lei "que manda olhar o juiz não seja duas vezes favorecido o acusado no espaço de cinco anos" assegura o rigor do registro, não o seu cancelamento (BRASIL. Tribunal de Alçada Criminal. Mandado de Segurança $\mathrm{n}^{\circ}$ 398.542-8/Jundiaí, Relator: Carlos Biasotti, da $15^{\mathrm{a}}$ Câmara, São Paulo, SP, 7 de março de 2002. Revista dos Juizados Especiais, São Paulo, ano 7, v. 23, p. 207-211, jan./mar. 2002).

${ }^{388}$ MACHADO, Daniel Felipe, op. cit., n. VIII, p. 18-19.
} 
renúncia ao direito de queixa ou representação.

Caso o ofendido não representar ou celebrar acordo civil, tais situações devem ser anotadas no registro criminal, ressalvando-se que a anotação somente seria divulgada para atender a requisição judicial ou do Ministério Público. A inserção dessa informação permite verificar pela análise do registro criminal, sem consulta ao juízo, o que ocorreu a partir da inclusão no registro da notícia de infração de menor potencial ofensivo.

Existe outra situação que envolve a infração penal de menor potencial ofensivo e o registro criminal que merece análise.

O autor de infração de menor potencial, por razões diversas, poderá não se sujeitar às medidas despenalizadoras e ser submetido ao processo criminal na forma do artigo $77 \mathrm{e}$ seguintes da Lei $\mathrm{n}^{\circ}$ 9.099, de 1995. Se condenado por decisão judicial ao pagamento de pena de multa exclusiva surgirá a situação prevista no parágrafo único do artigo 84 da Lei $\mathrm{n}^{\text {o }} 9.099$, de 1995, com reflexos no registro criminal. ${ }^{389}$

Acerca desse ponto, não cabe adotar a idéia sintética de que "não ficará constando a condenação à pena de multa" no registro criminal, ${ }^{390}$ pois esse posicionamento não condiz com os estudos até o momento realizados, especialmente com a regra do automatismo da inscrição dos dados no registro criminal.

É preciso explicitar que a disposição examinada e tratada pela Lei $n^{0} 9.099$, de 1995, não contraria a mencionada regra do automatismo do registro, porque a decisão condenatória que impõe o pagamento de multa exclusiva pela prática de infração penal de menor potencial ofensivo será inscrita no registro criminal. Isso se comprova, pois é possível informar ao juiz da sua existência no caso de ele requisitar essa informação.

Entretanto o acesso ao conteúdo dessa anotação, depois de paga a multa e extinta a punibilidade, é restrito, porque posteriormente o juiz deverá determinar, na forma da lei e explicitamente, que a referência à condenação "não conste dos registros criminais".

Essa providência não se trata do apagamento ou cancelamento dos dados do registro, mas restrição à publicidade do seu conteúdo.

Nessa situação, não vige o princípio da reserva da inscrição, que exclui

389 “Art. 84 - Aplicada exclusivamente pena de multa, seu cumprimento far-se-á mediante pagamento na Secretaria do Juizado.

Parágrafo único - Efetuado o pagamento, o Juiz declarará extinta a punibilidade determinando que a condenação não fique constando dos registros criminais, exceto para fins de requisição judicial."

390 TOURINHO NETO, Fernando da Costa; FIGUEIRA JÚNIOR, Joel Dias. Juizados Especiais Estaduais Cíveis e Criminais. 4. ed. São Paulo: RT, 2005. p. 637. 
determinados tipos penais da publicidade restringindo o uso do registro a certos casos e pessoas determinadas, mas restrição regulada à divulgação das informações inseridas no registro criminal. ${ }^{391}$

Nota-se que essa norma não abrange as situações em que o juiz condenar a pessoa acusada pela prática de infração penal de menor potencial ofensivo, impondo-lhe pena privativa de liberdade ou restritiva de direitos, ou uma delas cumuladas com pena de multa.

O objetivo do tratamento legislativo diferenciado, no caso isolado de condenação seguida do pagamento da multa, "é o de silenciar qualquer efeito civil ou funcional que poderia acarretar com a divulgação do registro criminal", 392 que se funda na preservação da privacidade dos dados pessoais armazenados no registro, amparado pela Constituição Federal.

Essa medida também reduz a estigmatização do condenado e estimula o pagamento da multa, pois se ele não quitá-la, nem justificar por que não o fez, a restrição ao acesso não deve ser declarada pelo juiz.

Ao abordar a questão da infração penal de menor potencial ofensivo e o registro criminal no Brasil, é possível fazer outro comentário considerando o regramento legal lusitano revogado e o vigente, ambos relacionados ao assunto.

Em Portugal toda conduta criminal era inscrita no registro criminal a partir de regra inserida no artigo $3^{\circ}$ do Decreto-Lei 39/83, de 25 de Janeiro, disposição que refletia a postura do Direito Penal português de não diferenciar "bagatelas penais" de crimes de maior gravidade. Essa orientação foi mantida pela Lei 57/98, de 18 de Agosto, que, entretanto, inovou permitindo que os tribunais, ao condenar alguém ao cumprimento de pena de prisão até um ano ou pena não privativa de liberdade, se as circunstâncias da prática do crime não indicarem perigo da prática de outros, possam determinar a nãotranscrição da sentença nos certificados expedidos pelo registro criminal a pedido de particulares para fins de emprego e outras finalidades. ${ }^{393}$

Concluindo este item do estudo, nota-se que o modelo previsto pela Lei $\mathrm{n}^{\circ}$ 9.099, de 1995, não impede o registro dos fatos relacionados à infração de menor potencial ofensivo, nem determina seja criado sistema paralelo para anotá-los, mas impõe restrição à divulgação dos dados relativos à transação penal e sentença penal condenatória com

\footnotetext{
${ }^{391}$ GROSSO GALVAN, Manuel, op. cit., p. 207.

${ }^{392}$ MACHADO, Daniel Felipe, op. cit., n. VIII, p. 19.

${ }^{393}$ VEIGA, Catarina, op. cit., p. 58-59. Ver artigos $17^{\circ}, 11^{\circ}$ e $12^{\circ}$, da Lei 57/98, de 18 de Agosto.
} 
imposição de multa exclusiva. Esse modelo, aliás, reforça a proteção constitucional à privacidade do registro criminal.

\subsection{Suspensão processual e registro criminal}

Deverá ser inscrita no registro criminal a decisão judicial que declarar a suspensão do processo pela não-localização do acusado, depois de citado por edital, sem comparecer ou constituir defensor, conforme prevê o artigo 366 do Código de Processo Penal. A necessidade de proceder-se à referida comunicação não está prevista em lei, mas é providência que resulta da interpretação do regramento inserido no mencionado artigo da lei processual penal a partir da edição da Lei $n^{\circ}$ 9.271, de 17 de abril de 1996, recentemente alterada pela Lei $\mathrm{n}^{\mathrm{o}} 11.719$, de 20 de junho de 2008, que entrou em vigor 60 (sessenta) dias após a data de sua publicação. ${ }^{394}$

No Brasil, conforme exposto anteriormente, a começar do encaminhamento dos autos do inquérito policial ao juízo, os dados do investigado são comunicados e anotados no registro criminal.

Se existir causa para a suspensão do processo, na forma ora tratada, o sistema de registro deverá ser alimentado com a notícia da decisão judicial que suspendeu o andamento do processo.

Essa causa, cujo afastamento depende de o juízo conseguir realizar a citação pessoal ou com hora certa do acusado, ${ }^{395}$ do comparecimento do próprio acusado em juízo ou de providência deste para a constituição de defensor, pode desaparecer a qualquer momento e permitir a retomada da tramitação processual.

\footnotetext{
${ }^{394}$ A Lei $\mathrm{n}^{\mathrm{o}} 11.791$, de 2008, revogou, expressamente, os parágrafos $1^{\mathrm{o}}$ e $2^{\circ}$ do artigo 366 do Código de Processo Penal, adiante transcritos, além de ter sido vetado pelo Presidente da República o novo texto do caput mencionado do artigo, permanecendo em vigor, portanto, o texto original do referido artigo, conforme redação da Lei no 9.271, de 1996: “Art. 366 - Se o acusado, citado por edital, não comparecer, nem constituir advogado, ficarão suspensos o processo e o curso do prazo prescricional, podendo o juiz determinar a produção antecipada das provas consideradas urgentes e, se for o caso, decretar prisão preventiva, nos termos do disposto no art. 312.

$\S 1^{\circ}$. As provas antecipadas serão produzidas na presença do Ministério Público e do defensor dativo (revogado).

$\S 2^{\circ}$. Comparecendo o acusado, ter-se-á por citado pessoalmente, prosseguindo o processo em seus ulteriores atos (revogado)."

${ }^{395}$ O artigo 392 do Código de Processo Penal, a partir das alterações produzidas pela Lei $\mathrm{n}^{\mathrm{o}}$ 11.791, de 2008, dispõe que: "Verificando que o réu se oculta para não ser citado, o oficial certificará a ocorrência e procederá a citação com hora certa, na forma estabelecida nos arts. 227 a 229 da Lei n ${ }^{\circ} 5.689$, de 11 de janeiro de 1973 - Código de Processo Civil", enquanto o parágrafo único do mesmo artigo determina que: "Completada a citação com hora certa, se o acusado não comparecer, ser-lhe-á nomeado defensor dativo."
} 
Retomado o curso da ação penal, esta poderá resultar, ainda, em eventual decisão judicial condenatória que será noticiada ao Instituto de Identificação ou repartição congênere, responsável pela formação do registro criminal, por intermédio do boletim individual tratado no parágrafo $3^{\circ}$ do artigo 809 do Código de Processo Penal.

A anotação, resultado da propositura da ação penal, já lançada no registro, deverá ser atualizada com a notícia da suspensão processual que deve ser mantida no cadastro até sua revogação. ${ }^{396}$

O motivo para inclusão da anotação no registro criminal da suspensão do processo pela não-localização do acusado é facilitar que ele seja encontrado, providência que permitirá retomar a tramitação processual a partir de sua citação pessoal ou da constituição de defensor.

A folha de antecedentes somente contém outros dados qualificativos da pessoa nela individualizada, como nome, filiação, data e local de nascimento, número do documento de identidade oficial, algumas vezes a fórmula datiloscópica.

Entretanto, a folha de antecedentes não contém o endereço do acusado, principalmente por tratar-se de dado alterável com facilidade. Parece existir outra razão que também justifica o desinteresse em anotar-se esse dado na folha de antecedentes, pois o sistema processual penal não exigia citar pessoalmente o acusado para permitir o seguimento válido do processo, realidade alterada em meados de 1996, porque até então era regular a citação editalícia do acusado não encontrado, exceto em situações bem definidas, como no caso de ele encontrar-se preso por outro processo na mesma unidade da Federação em que o juiz exerce a sua jurisdição, conforme Súmula $n^{\circ} 351$, do Supremo Tribunal Federal.

A tarefa de localizar o acusado, realizada de diversas formas, é facilitada pelo exame periódico da folha de antecedentes. Essa análise poderá indicar se em relação ao acusado foi instaurada nova investigação policial ou ajuizada ação penal, ou, ainda, decretada ou cumprida ordem de prisão, situações que facilitarão buscar sua localização a partir de consultas feitas aos dados compilados no novo inquérito ou processo.

A questão do não-atendimento do chamamento judicial pessoal ao processo e a

\footnotetext{
${ }^{396}$ A fixação de prazo para manutenção da suspensão processual gerada pela citação editalícia sem o comparecimento do acusado ou sem a constituição de defensor pelo próprio acusado, foi projetada pelo inciso I do parágrafo $2^{\circ}$ da Lei $n^{\circ} 11.719$, de 2008 , cuja redação foi vetada pelo Presidente da República. O texto vetado estava assim redigido: "ficará suspenso o curso do prazo prescricional pelo correspondente ao da prescrição em abstrato do crime objeto da ação (art. 109 do Código Penal); após, recomeçará fluir aquele.”
} 
necessidade de recorrer-se à citação ficta, por edital, conhecida como contumácia, são tratadas em Portugal pela legislação regulada da identificação e do registro criminal. Nesse país, o registro de contumazes está previsto pelos artigos $18^{\circ}$ a $20^{\circ}$ da Lei $57 / 98$, de 18 de Agosto.

O registro de contumazes português permite recolher, tratar e divulgar a informação sobre argüidos e condenados contumazes, com a finalidade de "garantir a eficácia das medidas de desmotivação de ausência", considerando-se como a principal a emissão do certificado de contumácia. Esse registro pode conter decisões judiciais que declarem a contumácia, alterem essa declaração ou a façam cessar, estando acessível ao titular da informação ou a quem provar que faz o pedido em nome ou no interesse daquele. Estão habilitados ao acesso ao registro de contumazes as entidades que podem acessar o registro criminal, as entidades públicas a quem incumbir assegurar a execução dos efeitos da contumácia e os terceiros que comprovem que seu pleito visa acautelar interesses ligados à celebração de negócio jurídico com pessoa declarada contumaz. ${ }^{397}$

Observa-se que a legislação portuguesa abrange a anotação de dados referentes a processos em relação aos quais os acusados foram condenados e considerados contumazes, tema próprio no Brasil ao cadastro das pessoas condenadas.

No Brasil, na prática, é o acesso à folha de antecedentes, assunto a seguir estudado, que facilita ao órgão judicial ou do Ministério Público ${ }^{398}$ localizar o acusado nos casos em que o processo e prazo prescricional são suspensos em virtude da citação editalícia e do seu não-comparecimento ou de advogado conforme dispõe o artigo 366 do Código de Processo Penal, segundo a Lei $n^{0}$ 9.271, de 1996, recentemente alterada pela Lei $n^{\circ} 11.719$, de 20 de junho de 2008, que entrou em vigor 60 (sessenta) dias após a data de sua publicação.

O legislador nacional, entretanto, poderia inspirar-se na legislação editada em Portugal e utilizar o acesso pessoal ao registro criminal como mecanismo para comunicar ao acusado acerca da existência de processo criminal movido em sua relação. Essa postura, conseqüentemente, reduziria a incidência da suspensão processual decorrente da citação por

\footnotetext{
${ }^{397}$ VEIGA, Catarina, op. cit., p. 154-155.

398 Para atingir essa finalidade, o Ato n 168/98-PGJ-CGMP, de 21 de dezembro de 1998 (Publicações Eletrônicas Associação Paulista do Ministério Público. São Paulo: APMP, 2004-2006. 1 CD-ROM. Produzido por Eduardo Roberto Alcântara Del-Campo e Marinilce Araújo Soria), que aprovou o Manual de Atuação Funcional dos Promotores de Justiça do Estado de São Paulo, recomendou aos Promotores de Justiça manter na Promotoria a relação dos processos suspensos com base no art. 366 do Código de Processo Penal e requerer periodicamente informações da Coordenadoria dos Estabelecimentos Penais do Estado, da Casa de Detenção de São Paulo e da Divisão de Vigilância e Capturas da Polícia Civil (DVC) sobre eventual prisão do acusado, dados que poderão ser encontrados na folha de antecedentes.
} 
edital sem o comparecimento ou nomeação de defensor, efeito que a alteração legislativa do Código de Processo Penal, indicada no final do parágrafo anterior, procurou intensificar a partir da admissão da citação com hora certa no processo penal brasileiro, forma de chamamento ao processo agora prevista pelo artigo 362 do Código de Processo Penal.

Facultar-se ao próprio acusado ter acesso aos dados do registro criminal e pela prática desse ato certificar-se a comunicação relativa à existência de processo ajuizado contra ele próprio, cujo andamento está suspenso em razão da citação editalícia sem comparecimento ao juízo ou nomeação de defensor, ofereceria ao acusado informe seguro a respeito da existência do processo e também lhe permitiria avaliar a viabilidade de comunicar-se com o juízo perante o qual tramita esse processo e exercitar o direito à ampla defesa.

O acesso pessoal e a documentação da presença do acusado buscando informação compilada no registro criminal deveriam servir como outra forma de levar notícia da existência do processo que foi movido contra ele próprio e cujo andamento foi suspenso, providência que poderia ser discutida pelo legislador nacional.

Em poucas palavras, o informe referente à existência do processo movido contra o acusado, levado ao seu conhecimento mediante acesso pessoal e documentado ao registro criminal, deveria ser relacionado na legislação nacional como justificador da revogação da decisão judicial que decretou a suspensão do processo. Nessa hipótese, apesar de o acusado não ter tomado conhecimento profundo do conteúdo da acusação, saberá que lhe é imputado o envolvimento com a prática de crime, situação que pouco difere da citação com hora certa que, ao ser concluída, também gera conhecimento ficto do conteúdo da acusação.

É preciso frisar que no Brasil o acesso ao registro feito pelo próprio interessado ou por terceiro, em nome daquele, seguido da expedição da certidão na qual conste notícia da existência de processo suspenso, não é causa legal do afastamento da situação que ensejou a suspensão.

A questão do acusado que acessou, comprovadamente, dados individuais do seu registro criminal e obteve notícia comprovada da existência de processo suspenso e dos efeitos processuais que isso poderia gerar, merece análise e propostas para sua estruturação no processo penal brasileiro, de modo que as regras complementares que tratem desse tema possam ser editadas. Referida alteração legislativa poderia acarretar eficácia e maior utilidade ao registro se permitisse acesso ao conteúdo do registro criminal ao mesmo tempo em que preservasse o direito de o acusado ser processado com conhecimento da acusação 
que é movida contra ele.

\subsection{Rol de culpados, folha de antecedentes e registro criminal}

É efeito da sentença penal condenatória recorrível o lançamento do nome do réu no rol dos culpados, ${ }^{399}$ conforme previsão do artigo 393, inciso II, do Código de Processo Penal.

Mencionada providência, entretanto, exige o trânsito em julgado da sentença penal condenatória, porque a interpretação literal do dispositivo inserido no Código de Processo Penal é incompatível com a consagração constitucional da presunção de inocência. 400

Sob esse aspecto cabe frisar que, até a entrada em vigor da Constituição Federal de 1988, essa providência também deveria ser adotada aos acusados pronunciados pela prática de crime doloso contra a vida, em observância ao disposto no texto revogado do parágrafo $1^{\circ}$ do artigo 408 do Código de Processo Penal.

Entretanto, a leitura dessa norma também foi alterada a começar da interpretação do princípio da presunção de inocência, inscrito no artigo $5^{\circ}$, inciso LVII, do referido texto constitucional e definitivamente mudado a partir da vigência da Lei 9.033, de 1995, que alterou a redação do artigo 408, parágrafo $1^{\circ}$, do Código de Processo Penal e dele retirou a previsão de lançar o nome do réu no rol de culpados quando da pronúncia. ${ }^{401}$

Recentemente, a Lei $\mathrm{n}^{\mathrm{o}}$ 11.689, de 9 de junho de 2008, que modificou os dispositivos do Código de Processo Penal relativos ao Tribunal do Júri, observou o princípio constitucional da presunção de inocência e não trouxe qualquer previsão quanto à inserção do nome do acusado pronunciado no rol de culpados.

O rol de culpados, em poucas palavras, é o registro judicial das condenações. A única finalidade que ainda parece cumprir é servir para auxiliar a constatação dos antecedentes criminais e da reincidência dos acusados.

É possível entender, todavia, que o livro de registro de sentenças que contém o rol de culpados não guarda relação direta com o registro criminal. Manter o registro das

\footnotetext{
399 Francisco Bissoli Filho (op. cit., p. 60) afirma, a partir de estudos, que o rol de culpados surgiu por disposições das Ordenações do Reino, especificamente, a começar do Código Filipino, indicando que nele se inscreviam os nomes das pessoas condenadas pela justiça criminal.

${ }^{400}$ GRECO FILHO, Vicente. Manual de processo penal. S. Paulo: Saraiva, 6. ed., 1999. p. 339.

${ }^{401}$ FRANCO, Alberto Silva; STOCO, Rui (Coord.), Código..., cit., v. 2, p. 2468.
} 
sentenças é obrigação imposta ao escrivão judicial. Ele deve ser escriturado em livro especialmente destinado a esse fim conforme menciona o artigo 389 do Código de Processo Penal. Referida inscrição constitui providência "apenas complementar e se destina a imprimir maior segurança à documentação". 402

O registro da sentença pode servir também como matriz para sua reprodução ou, como referência da decisão, caso o processo no qual foi prolatada esteja fora do cartório ou, eventualmente, extraviado. Por não estar classificado de modo a permitir consulta rápida aos nomes das pessoas condenadas pela justiça, empregá-lo para pesquisar antecedentes é providência que exige tempo e paciência.

A Lei $\mathrm{n}^{\mathrm{o}} 11.719$, de 20 de junho de 2008, que alterou vários artigos do Código de Processo Penal, perdeu a oportunidade de revogar, expressamente, o inciso II do artigo 393 do Código de Processo Penal. Diante daquilo que foi visto, a elaboração de relação nominal das pessoas condenadas pela prática de crime em determinado juízo, denominada rol de culpados, é providência que deveria ser dispensada, pois se mostra ineficiente ao reunir dados cujas fontes são decisões condenatórias proferidas por único juízo criminal e não permitir consulta rápida. Além disso, as informações que podem ser fornecidas pela consulta ao rol de culpados decerto serão conseguidas com maior rapidez, amplitude e segurança mediante acesso ao registro criminal.

Apesar de a lei processual penal ainda não dispensar a elaboração do rol de culpados, é possível verificar que são restritas as informações obtidas ao consultar-se esse rol se comparadas aos resultados das buscas feitas no registro criminal, argumento que orienta pensar que sua manutenção não deve ser obrigatória, inclusive por tratar-se de providência burocrática e onerosa, cujo acesso pode ser substituído pela consulta ao registrado criminal. Dispensar a elaboração do rol de culpados, a despeito de faltar lei revogadora, poderia ser orientação dos órgãos correicionais aos juízos criminais, pois essa postura não resulta em ofensa a direito e garantia individual, nem viola normas do devido processo penal, mas ajusta regra procedimental à realidade.

Em relação à folha de antecedentes, cabe destacar ser uma das tarefas atribuídas à autoridade policial durante a investigação juntá-la aos autos do inquérito policial, conforme dispõe o artigo $6^{\circ}$, inciso VIII, parte final, do Código de Processo Penal.

A folha de antecedentes é documento empregado internamente tanto que "não é fornecida a particular algum, nem mesmo à pessoa que se referia. Serve para uso interno da 
Polícia e para fornecimento de informações ao Ministério Público e ao Poder Judiciário". 403 Nela constarão as seguintes informações:

a) inquéritos policiais nos quais determinada pessoa foi indiciada e seu andamento ou destino;

b) processos criminais nos quais a pessoa foi acusada e o seu andamento ou desfecho;

c) outras qualificações usadas pela pessoa.

No Estado de São Paulo, faz algum tempo que nesse documento existem campos nos quais são apresentadas informações relacionadas ao envolvimento da pessoa com infrações penais de menor potencial ofensivo, reguladas pela Lei nº 9.099, de 1995, tema já abordado, além dos informes relacionados às passagens carcerárias e relativas à execução penal.

A folha de antecedentes, folha de antecedentes criminais, folha penal ou folha de antecedentes penais, usualmente tratada pelas iniciais "FA" ou "FAC", já chamada de "boletim de antecedentes", ${ }^{404}$ é documento organizado pelo Instituto de Identificação e Estatística ou repartição congênere, por disposição do Código de Processo Penal, a partir das informações fornecidas pela polícia ${ }^{405}$ e justiça. ${ }^{406}$ Ele reúne várias informações não somente relacionadas aos processos criminais com resultado condenatório, e serve para conhecer, de forma ampla, todos os envolvimentos criminais de determinada pessoa.

A folha de antecedentes funciona, também, como uma espécie de índice, porque a partir do exame dos dados nela reunidos é possível buscar documentos comprobatórios de processos criminais em andamento ou com decisão condenatória definitiva para configurar maus antecedentes criminais e a reincidência.

No Estado de São Paulo, a base de dados que integra os arquivos do Instituto de Identificação Ricardo Gumbleton Daunt, da Polícia Civil paulista, responsável no Estado pelo fornecimento das informações que incorporam a folha de antecedentes, está à disposição da justiça criminal por meio de acesso à distância em grande parte das unidades judiciárias. Esse acesso informatizado foi regulado pelo Provimento $n^{\circ}$ 9, de 1992, da

\footnotetext{
${ }^{403}$ NOGUEIRA, Carlos Frederico Coelho. Comentários ao Código de Processo Penal. São Paulo: Edipro, 2002. p. 335.

${ }^{404}$ NORONHA, Edgard Magalhães. Curso de direito processual penal. 18. ed. São Paulo: Saraiva, 1987, p. 19.

${ }^{405}$ Artigo 23 do Código de Processo Penal.

${ }^{406}$ Artigo 809, parágrafo $3^{\circ}$, do Código de Processo Penal.
} 
Corregedoria-Geral da Justiça, incorporado às Normas de Serviço desse órgão. ${ }^{407}$

Também no Estado São Paulo, a obrigação imposta à autoridade policial pela lei processual penal de fazer juntar a folha de antecedentes do indiciado foi mitigada pela Corregedoria-Geral da Justiça. Referido órgão considerou obrigatória a remessa ao juízo da folha de antecedentes somente nos casos de prisão em flagrante delito, permitindo nas demais hipóteses a coleta dos dados necessários para sua obtenção pelo juízo, ao qual é determinada a requisição desse documento ao receber a denúncia. ${ }^{408}$

No Brasil, portanto, a folha de antecedentes agrega informações produzidas pelo órgão policial que realizou as investigações e pela unidade judiciária perante a qual o processo criminal tramitou, resultado respectivo do trabalho policial investigativo e do ajuizamento das ações penais movidas pelo Ministério Público e pelos querelantes.

Em Portugal, o documento que integra todos os antecedentes criminais da pessoa é conhecido como certificado do registro criminal. ${ }^{409}$

O fornecimento de informações relativas à determinada pessoa com base nos dados armazenados no registro exige coincidência exata entre a identificação da pessoa e a ostentada pelo sujeito cuja anotação está inserida no arquivo pesquisado. Em outras palavras, a busca dos antecedentes penais deve ser precedida da definição da identidade do indivíduo cujos antecedentes criminais pretende-se conhecer. Essa tarefa não é própria do sistema de registro criminal e deve ser efetivada pela polícia e pelos peritos, normalmente os papiloscopistas que empregarão o método datiloscópico ou outros que se mostrem úteis e compatíveis para determinação da identidade da pessoa antes da realização da pesquisa no registro criminal. ${ }^{410}$

Essa análise permite considerar que para emitir a folha de antecedentes criminais é essencial o confronto entre os dados individuais referentes à pessoa em relação à qual se

407 “81.7. O funcionário que efetuar as pesquisas na base-de-dados do Instituto de Identificação Ricardo Gumbleton Daunt, certificará na folha de antecedentes que for expedida: 'Certifico ter acessado, por mídia eletrônica, a base-de-dados do IIRGD, extraindo em impressora as informações constantes desta peça', consignando data, nome e matrícula" (PROVIMENTO No 9, de 1992, da Corregedoria-Geral da Justiça. Publicações Eletrônicas Associação Paulista do Ministério Público. São Paulo: APMP, 2004-2006. 1 CDROM. Produzido por Eduardo Roberto Alcântara Del-Campo e Marinilce Araújo Soria).

${ }^{408}$ As Normas de Serviço da Corregedoria-Geral da Justiça do Estado de São Paulo (cit.), no item 81.4., dispõem que: "A autoridade policial requisitará a folha de antecedentes somente em caso de prisão em flagrante, sendo atendida preferencialmente pelo IIRGD, desde que destacada a condição de pessoa presa. Nos demais casos, a autoridade policial se limitará apenas a colher os dados indispensáveis à posterior obtenção da folha de antecedentes pelo juiz (qualificação completa, identificação datiloscópica e R.G.)" (NOGUEIRA, Carlos Frederico Coelho, op. cit., p. 336).

${ }^{409}$ VEIGA, Catarina, op. cit., p. 119.

410 GALVAN, Manuel Grosso. Los antecedentes penales: rehabilitacion y control social. Barcelona: Bosch, 1983, p. 129-133. 
pretende obter tais informações e aqueles inseridos no sistema sob pena de eventual falta de absoluta coincidência entre um e outro resultar na expedição de informações de outra pessoa.

É importante que na folha de antecedentes criminais conste o nome, a filiação, a data e o local de nascimento, número de documento de identidade e fórmula datiloscópica os quais permitirão confronto simples e objetivo. Se preciso, poderá ser feita pesquisa detalhada para confrontar as impressões digitais.

Deveria ser providenciada a inclusão da fotografia da pessoa cujos dados constam na folha de antecedentes, por retratar-lhe alguns caracteres pessoais que poderão ser importantes nos casos de dúvida de identidade. A adoção dessa providência ampliaria a oferta de dados relacionados à pessoa e seria mera transcrição da identificação criminal, que abrange o processo datiloscópico e fotográfico, nos exatos termos da Lei $\mathrm{n}^{\circ} 10.054$, de 7 de dezembro de 2000, que dispõe sobre a identificação criminal.

A folha de antecedentes, portanto, é documento utilizado para instruir investigações e processos que exteriorizam os antecedentes criminais das pessoas. Expedida pelo Instituto de Identificação e Estatística ou repartição congênere, serve de índice dos dados reunidos no registro criminal.

\subsection{Reincidência e registro criminal}

É necessário conhecer conceitos básicos de antecedentes criminais e da reincidência para, em seguida, verificar o relacionamento deles com o registro criminal.

Os antecedentes penais e a reincidência são temas inter-relacionados, ${ }^{411}$ pois é por meio do exame deles que esta ficará caracterizada e, em algumas ocasiões, ambos se entrelaçam profundamente, embora um só fato não deve ser considerado a título de antecedente e reincidência, sob pena de gerar bis in idem. Antecedentes podem ser considerados como gênero, enquanto a reincidência surge como espécie no campo da

411 Francisco Bueno Arús (op. cit., p. 47) considera que "la existencia de un Registro de gestión administrativa dónde consten los antecedentes penales de las personas que cometan delitos es necesaria para la realización de una serie de actuaciones judiciales y procesales respecto de las cuales no es indiferente la condición de delincuente primario o no del interesado. Carece interés que las consecuencias de tales antecedentes se fundamenten en la mayor antijuridicidad de la conducta realizada o bien en la mayor culpabilidad o peligrosidad del sujeto, así como que la doctrina subyacente a tales consecuencias sea de naturaleza retributiva o preventiva" 
existência anterior de condenação criminal, tratando ambos da vida pretérita da pessoa. ${ }^{412}$

Antecedentes e reincidência estão ligados, diretamente, ao registro criminal, porque este deve reunir todas as informações relacionadas ao passado criminal de determinada pessoa para permitir a demonstração daqueles.

$\mathrm{Na}$ Espanha foi afirmado que a principal função do registro de antecedentes penais é facilitar a apreciação da circunstância agravante da reincidência e proporcionar ao órgão julgador conhecer as outras condenações impostas ao mesmo acusado. ${ }^{413}$

A reincidência já foi apontada como fator indicativo, embora não isolado, da eficiência do sistema penal, tanto que alguns a consideram como "pedra de toque", embora não possa ser esquecido que os organismos que investigam e apuram os crimes são seletivos, ou seja, normalmente voltam o exercício das suas ações aos setores sociais bem delineados nos quais a prática criminal é mais freqüente. ${ }^{414}$

No Brasil as sentenças penais que concedem perdão judicial não se prestam a forjar reincidência. ${ }^{415}$ Também não servem para isso os crimes militares próprios e os crimes políticos, ${ }^{416}$ restringindo-se os efeitos de condenação anterior quando relacionada à prática de contravenção penal ou crime culposo. ${ }^{417}$ Além disso, não prevalece para fins de reincidência a sentença condenatória se, entre a data do cumprimento ou extinção da pena e a infração posterior, tiver decorrido período de tempo superior a 5 (cinco) anos, computado o período de prova da suspensão ou livramento condicional, se não ocorrer revogação. ${ }^{418}$

O último dispositivo da lei penal brasileira relativo à temporariedade da reincidência serve para estimular o argumento de que o sistema criminal deve estruturar-se de modo a determinar que, a partir do transcurso de certo período, o conteúdo de decisões da Justiça Criminal não esteja acessível a terceiros que possam acessar os dados do registro criminal.

A legislação penal da Espanha possui disposição semelhante, também denominada "prescrição da reincidência", mas nesse país o legislador avançou e dispôs que os antecedentes cancelados, bem como aqueles que não estejam, mas que deveriam estar, não serão computados pelo juiz. Francisco Bueno Arús, também aponta ser “conclusión lógica

412 BISSOLI FILHO, Francisco, op. cit., p. 59.

${ }^{413}$ BUENO ARÚS, Francisco, op. cit., p. 48. Concordaria em alterar o trecho:

${ }^{414}$ GROSSO GALVAN, Manuel, op. cit., p. 40 e 46.

415 Art. 120 do Código Penal.

${ }^{416}$ Art. 64, inciso II, do Código Penal.

${ }^{417}$ BISSOLI FILHO, Francisco, op. cit., p. 88.

${ }^{418}$ Art. 64, inciso I, Código Penal. 
desde la perspectiva del principio de presunción de inocencia" caber à acusação demonstrar "que los antecedentes penales que se intenta computar ni han sido cancelados ni hubieren podido serlo". 419

Não existe posição firme da jurisprudência nacional em relação à forma de provar-se a reincidência, seja por meio de certidões expedidas pelos ofícios judiciais ou mediante exibição da folha de antecedentes criminais.

Afirma-se que os tribunais entendem que a folha de antecedentes não serve para comprovar a reincidência ${ }^{420}$ e ser necessária a certidão judicial com data do trânsito em julgado da decisão condenatória para comprovar tal circunstância. ${ }^{421}$

Apesar disso, encontram-se algumas decisões do Superior Tribunal de Justiça nas quais são aceitas a folha de antecedentes ou certidão fornecida pelo Instituto Nacional de Identificação (INI), órgão da Polícia Federal, para comprovar essa causa geral de aumento de pena desde que contenham dados que identifiquem o processo e a unidade judiciária de origem, qualifiquem o acusado, indiquem o tipo penal por ele violado e tragam a data do trânsito em julgado. ${ }^{422}$

No julgamento do Recurso Especial $\mathrm{n}^{\circ}$ 285.750-DF, o Ministro Felix Fischer elaborou "voto-vista" e mencionou que, por vivência prática, entendia que a reincidência caracterizada por informação tomada a partir dos dados constantes do Instituto de

${ }^{419}$ Op. cit., p. 49-50.

${ }^{420}$ NOGUEIRA, Carlos Frederico Coelho, op. cit., p. 336.

${ }^{421}$ Cf. GOMES FILHO, Antonio Magalhães. Direito à prova no processo penal. São Paulo: RT, 1997, p. 98 e BISSOLI FILHO, Francisco, op. cit., p. 100. Ressalta-se, entretanto que o segundo autor refere julgados que admitiram provar a reincidência por outro modo, que não pela juntada de certidões judiciais.

${ }^{422}$ Os seguintes recursos especiais julgados pela $5^{\mathrm{a}}$ Turma, do Superior Tribunal de Justiça, registrados sob os $\mathrm{n}^{\mathrm{os}}$ 285.750-DF, relatado pela Ministra Laurita Vaz, julgado em 19 de agosto de 2003 e publicado no Diário da Justiça em 8 de março de 2004; 275.971-DF, relatado pelo Ministro Gilson Dipp, julgado em 24 de setembro de 2002 e publicado no Diário da Justiça em 11 de novembro de 2002; e 254.005-DF, relatado pelo Ministro José Arnaldo da Fonseca, julgado em 19 de março de 2002 e publicado no Diário da Justiça em 6 de maio de 2002, entenderam que a folha de antecedentes (somente o primeiro) e certidões (os demais) do Instituto Nacional de Identificação, desde que contenham dados que identifiquem o processo e a unidade judiciária de origem, qualifiquem o acusado, indiquem o tipo penal e tragam data do trânsito em julgado servem para caracterizar a reincidência. No acórdão do Recurso Especial $\mathrm{n}^{\circ}$ 285.750-DF, foi transcrita a ementa de outro acórdão que foi invocado pelo recorrente, no caso o Ministério Público do Distrito Federal, como precedente. $\mathrm{O}$ trecho da ementa transcrita do acórdão é o seguinte: "PENAL. HABEAS CORPUS. REINCIDENNCIA. COMPROVAÇÃO. CONCURSO DE CIRCUNSTÂNCIAS. MENORIDADE. CONCESSÃO DE OFÍCIO: A folha de antecedentes criminais expedida pela Polícia Civil é idônea a comprovar reincidência, até prova em contrário, quando dela constem as informações necessárias a identificação da condenação anterior e de seu trânsito em julgado. A sentença que não examina a repercussão da menoridade do acusado, mas considera, para efeito de agravamento da pena-base, a reincidência, não pode subsistir por causar prejuizo manifesto ao paciente, especialmente se considerado que aquela atenuante prevalece sobre as circunstâncias objetivas contrárias, inclusive a própria reincidência. Precedente (HC $n$. 66.605). Pedido indeferido, concedendo-se, no entanto, habeas corpus de oficio para, sem prejuízo da condenação, anular a sentença na parte em que fixada a pena, determinando-se ao juízo competente que outra seja prolatada, considerando-se a menoridade. (HC 70.873/RJ, Rel. Ministro Ilmar Galvão)”. 
Identificação "não são certidão de cartório, mas mera informação", nem sempre atualizada, "porquanto pode ter havido, posteriormente, revisão criminal, um habeas corpus, etc." (negrito original).

A referida posição é a mais adequada e garantista, pois também exigiu comprovação efetiva e irrefutável da condenação anterior, com base em certidão do juízo da vara criminal na qual o acusado foi condenado, para forjar a reincidência.

Apesar de a prova da reincidência ser questão controvertida nos tribunais, ${ }^{423}$ adota-se a idéia de ser indispensável juntar certidão judicial para provar a validez da condenação anterior para fins da reincidência, devendo tomar-se idêntico cuidado para provar os antecedentes criminais, ${ }^{424}$ especialmente diante dos sérios efeitos que ambas as circunstâncias poderão causar ao acusado.

Essa postura, sintonizada com o entendimento da doutrina, além de ser garantista, evita que eventuais desfechos modificativos da decisão condenatória com trânsito em julgado que não foram inseridos, por qualquer motivo, na folha de antecedentes, possam ser desconhecidos dos juízes que deverão apreciar novos processos movidos contra aqueles acusados.

Não se trata de reduzir a força probatória do conteúdo da folha de antecedentes, mas constatar que a precária regulamentação do registro criminal nacional e a falta de atribuição de responsabilidades definidas aos órgãos do sistema de justiça e do Instituto de Identificação e Estatística, ao realizarem trabalhos conjuntos relativos ao registro criminal, poderão ocasionar erros e omissões que possibilitarão prejudicar ou beneficiar, indevidamente, aquele que é processado.

${ }^{423} \mathrm{O}$ modo de provar a reincidência é questão discutida pelos tribunais. As ementas de alguns julgados permitem verificar que "a prova da reincidência também pode ser aceita através de confissão do réu de haver cumprido a pena anterior, cujo quantum, natureza do crime e local de cumprimento foram expressamente mencionados" (BRASIL. Tribunal de Alçada. Apelação Criminal n ${ }^{\circ} 2.125$, Relator: Vicente Borges, da $1^{\mathrm{a}}$ Turma da Câmara, Carmo do Cajuru, MG, 3 de setembro de 1971. RT, São Paulo, v. 440, p. 459-460, jun. 1972) e "haver desnecessidade de certidão cartorária fora dos casos de dúvida ou impugnação" (BRASIL. Tribunal Regional Federal - $2^{\mathrm{a}}$ Região. Apelação Criminal no 94.02.21346-5/RJ, Relator: Des. Federal Arnaldo Lima, da $3^{\text {a }}$ Turma. Rio de Janeiro, RJ, 7 de fevereiro de 1996. RT, São Paulo, v. 736, p. 715-721, fev. 1997). Em sentido oposto, outro julgado expõe na ementa que para comprovar essa circunstância agravante existe "necessidade de certidão da condenação anterior com trânsito em julgado e indicação da data de eventual cumprimento ou extinção da pena" (BRASIL. Tribunal de Alçada. Apelação Criminal ${ }^{\circ}$ 188.816-3, Relator: Djalma Lofrano, da 6 Câmara Criminal, Campinas, SP, 14 de setembro de 1995. Diário Oficial do Estado de São Paulo, Poder Judiciário, São Paulo, SP, 10 out. 1995. Caderno I).

${ }^{424}$ Francisco Bissoli Filho (op. cit., p. 63) aborda a questão da prova dos antecedentes criminais, destacando ressentir-se a folha de antecedentes da "fé pública" atribuída às certidões das escrivanias judiciais. 


\subsection{Antecedentes e registro criminal}

\section{O substantivo masculino "antecedentes" significa "fatos anteriores, que deixam} prever os que hão de seguir-se". ${ }^{425}$ No singular esse substantivo indica "fato que determina outro posterior". ${ }^{426} \mathrm{O}$ significado da palavra "antecedente(s)" no plural ou singular pressupõe diagnosticar fato passado visando construir idéia de ocorrência futura.

É nesse sentido, em geral, que os principais textos da legislação criminal brasileira emprega "antecedentes", ${ }^{427}$ sem defini-lo, ${ }^{428}$ postura diversa daquela que foi adotada pela lei penal em relação à reincidência, ${ }^{429}$ mas sob a idéia de significar fato anterior apreciável

${ }^{425}$ FERREIRA, Aurélio Buarque de Holanda, op. cit.

${ }^{426}$ MICHAELIS: moderno dicionário da língua portuguesa. São Paulo: Companhia Melhoramentos, 1998. p. 163.

427 “Antecedentes”, expressão usada na redação de diversos artigos da legislação criminal a seguir indicados, atende finalidades diversificadas também adiante expostas. No Código Penal: a) 44, inciso III (requisito para conversão da pena privativa de liberdade em restritiva de direitos); b) 59, caput (circunstância apreciada pelo juiz para fixar a pena); c) 71, parágrafo único (crime continuado específico, ou seja, praticado contra vítimas diferentes mediante violência e grave ameaça); d) 77, inciso II, e 83, inciso I (requisitos para a suspensão da pena e do livramento condicional); e) 168-A, $\S 3^{\circ}$, e $337-\mathrm{A}, \S 2^{\circ}$ (requisito para concessão do perdão judicial ou aplicação da pena de multa no crime de apropriação indébita previdenciária). No Código de Processo Penal: a) $6^{-}$, inciso VIII (juntar aos autos do inquérito policial a folha de antecedentes do indiciado); b) art. 20, parágrafo único (nos atestados de antecedentes solicitados à autoridade policial, esta não poderá mencionar quaisquer anotações referentes à instauração de inquérito contra os requerentes, exceto no caso de existir condenação anterior); c) 748 (proibição da menção à condenação ou condenações anteriores na folha de antecedentes do reabilitado, nem em certidão extraída dos livros do juízo, salvo quando requisitada por juiz criminal); d) 809, inciso V (ao inserir informações no "boletim individual" constarão dados acerca dos antecedentes judiciários do condenado). $\mathrm{Na}$ Lei de Execução Penal: a) $5^{\circ}$ (requisito para classificação e individualização concreta da pena); b) 106, inciso IV (informação que constará na guia de recolhimento); c) 114, inciso II (condição para ingresso no regime prisional aberto); d) 180, inciso III (condição para conversão da pena privativa de liberdade não superior a dois anos em privativa de direitos); e) 190 (exposição no relatório do Conselho Penitenciário a ser elaborado nos casos de anistia e indulto). O inciso II do artigo 114 da Lei de Execução Penal foi redigido para proporcionar condições para a harmônica integração social do condenado, conforme dispõe o artigo $1^{\circ}$ dessa lei, ao permitir substituir o exame dos antecedentes pela aferição do resultado dos exames a que foi submetido o condenado por ocasião em que o juiz verifica se existem fundados indícios do ajustamento do condenado à autodisciplina e senso de responsabilidade exigidos pelo regime aberto. Substituir a análise dos antecedentes pela aferição dos resultados desses exames é providência que merece destaque, pois demonstra abordagem diferente dos demais dispositivos legais relativos ao tema, que tratam antecedentes como uma espécie de vaticínio imutável ao qual se vincula a avaliação do juiz.

${ }_{428}$ Francisco Bissoli Filho (op. cit., p. 109) ressalta que "a vagueza ou a inexistência do conceito de antecedentes no Direito Positivo brasileiro" impõe que os operadores jurídicos se orientem na elaboração desse conceito por aquilo que denominou "meta-regras sociais", "second code (segundo código)" ou "basic rules (regras básicas)", esclarecendo que antecedentes criminais e reincidência exercem influência no "conceito de dolo, de previsibilidade (nos tipos culposos), de potencial consciência da ilicitude (pertencentes à teoria do crime), personalidade perigosa (pertencente à teoria do criminoso)".

${ }_{429}$ Antonio Magalhães Gomes Filho (Presunção..., cit., p. 58-63) trata da prisão cautelar no direito brasileiro diante das alterações introduzidas por diversas leis editadas até 1989 que refletiram na legislação processual penal e menciona o sensível abrandamento que a Lei $\mathrm{n}^{\circ} 5.941$, de 29 de novembro de 1973, causou ao rigoroso e revogado sistema da prisão cautelar obrigatória imposta ao réu pronunciado ou condenado por sentença recorrível. Depois de referir-se ao artigo 408, $\S 2^{\circ}$, do Código de Processo Penal, que permitia ao juiz, fosse o réu primário e de bons antecedentes, deixar de decretar-lhe a prisão ou revogá-la, caso se encontrasse preso, e a revogada redação do artigo 594, que dispunha que o réu não podia apelar sem recolherse à prisão, ou prestar fiança, salvo se primário e de bons antecedentes, assim reconhecido na sentença 
pelo juiz e dotado de potencial para influir sobre sua futura decisão.

Este estudo abordará os antecedentes sob o aspecto estritamente criminal, ou seja, a partir da aferição da existência de processos criminais e inquéritos policiais anotados no registro criminal do acusado. ${ }^{430}$ Não serão analisadas situações relacionadas à conduta social do acusado, porque a redação do artigo 59, caput, do Código Penal, a partir da Lei $\mathrm{n}^{\circ} 7.209$, de 1984, prevê a conduta social do réu como "circunstância independente dos antecedentes, esvaziando, por conseguinte, seu significado." 431

Os antecedentes criminais relacionam-se ao registro, pois os dados nele compilados serão as primeiras informações consultadas para constatação dos "antecedentes" de determinada pessoa.

Caso alguém não ostente antecedentes criminais deverá ser considerada como pessoa sem antecedentes, possuidora de bons ${ }^{432}$ ou ótimos antecedentes. Ao contrário, se ostentá-los, será considerada portadora de antecedentes, possuidora de maus ou péssimos antecedentes. Não cabe aprofundar o debate dos critérios que podem ser empregados para classificar alguém de portador de bons ou ótimos antecedentes criminais, pois fatos positivos ou meritórios não são anotados no registro criminal. Caberá, entretanto, apontar qual conteúdo encontrado no registro criminal permitirá afirmar que determinada pessoa é portadora de antecedentes criminais negativos, classificar a intensidade dos antecedentes para considerá-los maus ou péssimos e, finalmente, discutir se antecedentes anotados devem ser apagados ou desconsiderados depois do transcurso de certo lapso temporal.

A fixação de critério objetivo para considerar alguém portador de "(maus) antecedentes criminais" foi apontada como necessária para orientar as decisões judiciais acerca desse assunto a partir da aplicação do princípio da presunção de inocência, previsto

condenatória, ou condenado por crime de que se livre solto, o autor faz considerações relativas à personalidade do acusado e ensina que: "enquanto o conceito de primariedade é objetivo, resultando da existência ou não de condenação anterior, a idéia de 'bons antecedentes' é extremamente fluida, o que tem possibilitado a adoção de critérios jurisprudenciais extremamente largos, que incluem apreciações subjetivas a respeito da personalidade do agente e de circunstâncias do fato criminoso, estranhos à valoração da situação de perigo exigível para a decretação ou manutenção da custódia cautelar." Acerca dos artigos do Código de Processo Penal referidos nesta nota cabe assinalar que o artigo 408, $\S 2^{\circ}$, foi alterado pelo artigo $413, \S 3^{\circ}$, incluído pela Lei $n^{\circ} 11.689$, de 9 de junho de 2008, enquanto o artigo 594 foi revogado pela Lei $n^{\circ} 11.719$, de 20 de junho de 2008, que também inseriu parágrafo único ao artigo 387.

${ }^{430}$ Francisco Bissoli Filho (op. cit., p. 62-63), nesse trecho da obra, enumera e discute, com profundidade, as diversas situações consideradas a título de antecedentes pela Dogmática Penal.

${ }^{431}$ CAPEZ, Fernando. Curso de direito penal: parte geral. 11. ed. São Paulo: Saraiva, 2007. v. 1, p. 441.

432 Ao discorrer sobre o conceito de bons antecedentes, Alberto Zacarias Toron (A Constituição de 1988 e o conceito de bons antecedentes para apelar em liberdade. Revista Brasileira de Ciências Criminais, RT, São Paulo, n. 4, p. 71, out./dez. 1993) aponta "problema de natureza metodológica quanto aos dados que podem ser levados em consideração para sua aferição (se o senso comum ou os ditames da ciência do direito) até os limites cognitivos do juiz com relação a processos findos." 
no artigo $5^{\circ}$, inciso LVII, da Constituição Federal, pois somente a sentença penal condenatória irrecorrível permite considerar que determinada pessoa possui ou não "(maus) antecedentes criminais", enquanto "simples inquéritos ou até mesmo ações penais em andamento são dados que não devem ser levados em consideração, sendo fundamental aguardar o desfecho dos feitos." 433

Além da ofensa ao princípio da presunção de inocência, ao devido processo legal e à ampla defesa, que já foram afrontados pela "amplitude do conceito de antecedentes, que permite que sejam considerados, conforme visto, processos e inquéritos em trâmite, assim como inquéritos arquivados", sem que o fato ou a situação considerados a título de antecedente negativo sejam descritos na peça acusatória ou sem permitir ao acusado contrariá-los durante a tramitação do processo. ${ }^{434}$

Citada postura pode ser atribuída ao pouco cuidado dispensado ao interpretar-se o artigo 41 do Código de Processo Penal, que trata dos requisitos da denúncia ou queixa, sem exigir expressa referência ao antecedente criminal, caso seja pretensão do acusador empregar mencionada circunstância em desfavor do acusado, sem estrita observância das garantias previstas na Constituição Federal em seu artigo $5^{\circ}$, incisos LIV e LV, sem falar na eventual afronta ao inciso LVII, antes referida.

Os antecedentes criminais traduzem dupla intencionalidade. Se por um lado são aptos a apresentar um "caudal informativo mais que notável" para a individualização da pena, por outro servem como reprodutores de "induvidável tendência" a potencializar inclinações preconcebidas de alguns juízes e promotores que avaliam com maior rigor aqueles que ostentam anotações criminais. Além dessa avaliação subjetiva, o efeito objetivo que os antecedentes indicados pelo registro pode causar ao seu portador é intenso, tanto que já foi frisado que na Alemanha, em muitas ocasiões, a pena imposta àquele que ostenta

${ }^{433}$ MOYANO, Hélio A. Nogues. Um critério objetivo de antecedentes criminais. Boletim IBCCrim, São Paulo, n. 8, p. 3, set. 1993. O autor também indica que "existem apenas quatro tipos de acusados (réus ou indiciados), todos perfeitamente identificáveis. São eles: O primário sem (maus) antecedentes - contra o qual não existe sentença condenatória transitada em julgado, nem antes nem depois da ocorrência do(s) novo(s) ilícito(s); o primário com (maus) antecedentes - contra o qual existe uma ou mais sentenças condenatórias (todas) transitadas em julgado após a prática de novo(s) crime(s), ou, ainda, aquele que, apesar de ter contra si sentença(s) condenatória(s) definitiva(s), atende ao disposto no artigo 64 do CP; o reincidente sem (maus) antecedentes - contra quem existe apenas uma sentença condenatória transitada em julgado antes da prática do ou dos novos delitos, e; o reincidente com (maus antecedentes) - quem tem contra si duas ou mais sentenças condenatórias irrecorríveis, sendo que, pelo menos uma delas, transitou em julgado antes da prática da ou das infrações e não se adapta ao disposto no referido artigo 64 do CP" (negritos originais).

${ }^{434}$ BISSOLI FILHO, Francisco, op. cit., p. 66. 
maus antecedentes é duplicada. ${ }^{435}$

Francisco Muñoz Conde afirma que os antecedentes criminais ou penais são, sem dúvida, as mais desconhecidas e esquecidas conseqüências jurídicas do delito, são inúteis e estão em flagrante contradição aos fins teóricos e constitucionalmente reservados às penas e medidas de segurança, tratando de reminiscência da antiga flor de lis gravada a fogo no ombro ou na orelha do condenado. $O$ autor considera que a tendência da evolução legislativa é reduzir claramente seu âmbito de eficácia, porém pondera estar muito distante o momento do seu definitivo desaparecimento. ${ }^{436}$

Nota-se que essa afirmação de Muñoz Conde, escrita quase vinte e cinco anos atrás, é provocativa e exige esclarecimentos em razão do direcionamento dado a este trabalho no qual não se busca demonstrar a inutilidade dos antecedentes criminais, mas analisar o seu relacionamento com o registro criminal e demonstrar que no Brasil este deve ser estruturado de modo a não ofender direitos individuais e ser dotado de eficiência que facilite seu emprego para atender os fins previstos na legislação penal e processual penal.

Em relação às idéias apresentadas por Francisco Munõz Conde acerca dos antecedentes criminais, aquela que se afina com o presente estudo está relacionada à tendência da redução da eficácia dos antecedentes, aspecto adiante analisado.

Aliás, antecedentes criminais é assunto de que, inicialmente, todo estudante imagina conhecer e não se permite analisá-lo por considerar algo sabido de antemão e com reduzidas possibilidades de investigação em face do seu caráter burocrático. Ocorre que essa sensação desaparece ao aprofundar o estudo do tema, surgindo no seu lugar vários problemas e singularidades que transformam a visão acanhada daquele que imagina bem conhecer os antecedentes criminais. ${ }^{437}$

Os reflexos que os antecedentes criminais (ou penais) causam ao acusado no processo penal são múltiplos. Um dos mais comentados é orientar o juiz no momento de fixar a pena, ${ }^{438}$ mas pode ser aferido até como índice para avaliar a veracidade da confissão prestada pelo co-réu colaborador quando o juiz verifica na personalidade desse acusado condições favoráveis à concessão da delação premiada. ${ }^{439}$

Ao investigar fato aparentemente criminoso, a polícia tem necessidade e interesse

\footnotetext{
${ }^{435}$ GROSSO GALVAN, Manuel, op. cit., p. 39, especialmente, nota de rodapé 25.

${ }^{436}$ Id., ibid., p. IX e XI-XII. Prólogo de Francisco Muñoz Conde.

${ }^{437}$ Id., ibid., p. 1.

${ }^{438}$ Art. 59, caput, do Código Penal.

${ }^{439}$ SILVA, Eduardo Araújo. Crime organizado: procedimento probatório. São Paulo: Atlas, 2003. p. 146.
} 
de conhecer os antecedentes criminais do investigado. Mencionados dados, algumas vezes, servem para desencadear a propositura de medidas gravosas, tais como a prisão preventiva, que é rápida e freqüentemente aplicada ao acusado nos casos em que o juiz avalia negativamente seu passado pela existência de antecedentes criminais. ${ }^{440}$ e 441

$\mathrm{Na}$ Espanha, foi dito que os antecedentes penais geram reflexos como funcionar como agravante genérica, permitir que a prática de falta seja considerada como delito e resultar na aplicação de penas mais graves, além de resultar em efeitos acessórios, como gerar a revogação da liberdade condicional com perda do tempo de pena transcorrido nessa condição e impedir o indulto. Referidos efeitos foram suficientes para defesa da idéia da eliminação dos antecedentes penais do ordenamento jurídico. ${ }^{442}$

Antonio Magalhães Gomes Filho, ao tratar das máximas de experiência, indica que elas se fundam em conhecimentos comuns e "incluem na sua formulação elementos vagos, heterogêneos, mutáveis e ambíguos", por vezes confundidas "com generalizações, preconceitos, julgamentos morais e vulgarizações pseudocientíficas" freqüentemente "difundidas pelos meios de comunicação" que assumem indevida "condição de regras certas e universais, qualidades que em alguns casos não possuem". Ao expor seu raciocínio, o autor salienta exemplo sugestivo que é empregado por Vicente Greco Filho que fala do preconceito, utilizado com freqüência no juízo penal, referindo-se aos julgamentos feitos com base em simples antecedentes criminais. ${ }^{443}$

Ao tratar a Constituição Federal como a norma fundamental de cada comunidade, indicar que ela funciona como origem dos princípios que regem o ordenamento jurídico, considerar o processo penal como ramo desse ordenamento que detém princípios e regras próprios para comandar e orientar o legislador, o juiz e todo aquele que intervir no processo penal, Catarina Veiga consigna que os princípios processuais não estão previamente postos à disposição, porque eles são derivados e extraídos da prática dos tribunais, da doutrina e, principalmente, do grau de maturidade da consciência jurídica comunitária. Ao proceder a este estudo, a autora ressalta que "nada mais importante e imediato que as normas que governam a prática dos tribunais e juristas”. A seguir, expõe que as soluções dos problemas

\footnotetext{
${ }^{440}$ VEIGA, Catarina, op. cit., p. 121.

${ }^{441}$ A interferência dos antecedentes e da reincidência criminal "na formação do juízo de valor por parte dos operadores penais" e "diversos agentes do sistema penal [...] pode ser constatada nas decisões que ensejam a decretação de prisão cautelar" (BISSOLI FILHO, Francisco, op. cit., p. 106 e 109).

${ }^{442}$ GROSSO GALVAN, Manuel, op. cit., p. 52.

443 A referência ao texto de Vicente Greco Filho feita por Antonio Magalhães Gomes Filho na nota de rodapé $\mathrm{n}^{\circ} 111$ de sua obra (A motivação das decisões penais. São Paulo: RT, 2001. p. 165) foi por este extraída da página 13 do artigo jurídico "Regras de inferência" (Plural - Boletim Informativo do CEAF/Escola Superior do Ministério Público, 4(18): 9-14, 1999).
} 
no âmbito do processo penal dependem, portanto, do desenvolvimento social e cultural daquela comunidade, das suas concepções políticas de base e das concretas formas de poder nela vigentes, ou seja, da sua tradição histórica. ${ }^{444}$

A afirmação da autora acerca dos princípios e regras, somado ao entendimento de Antonio Magalhães Gomes Filho e ao exemplo apresentado por Vicente Greco Filho, antes citados, permitem demonstrar quanto é importante a interpretação do juiz referente aos dados anotados no registro criminal do acusado. Nessa avaliação, quanto maior rigor o juiz impuser para analisar o tipo de informação que lhe é oferecida, mais desfavorável será a interpretação que ele poderá fazer dos antecedentes da pessoa processada.

Na Espanha, foi considerado que antecedentes penais, sob uma ótica estrita, são as informações remetidas diretamente pelos tribunais penais ao Registro Central de Procesados y Penados, com o fim de constatar a reiteração ou a reincidência em relação aos delinqüentes e permitir ao Estado controlar mais severamente e reprimir os indivíduos. Os antecedentes penais ganham sentido a partir da condenação e cumprem o papel de recolher, arquivar e classificar as sentenças penais, servindo como base para o registro criminal. $^{445}$

Os estudos processuais penais feitos por Antonio Scarance Fernandes, no campo da reação defensiva à imputação ampla, apontam que o indiciamento é o meio pelo qual se inclui o nome do indiciado nos registros policiais. $\mathrm{O}$ autor descreve a dificuldade para o cancelamento dos registros nos casos de arquivamento do inquérito policial, absolvição, cumprimento de pena e reabilitação, conceituando "árdua a luta" das pessoas que pretendem alcançar esse objetivo. Comenta, também, que o registro é permanente, permite o fornecimento de informações quando solicitadas e atinge o conceito social da pessoa. Adverte, por fim, especificamente, que conforme a orientação adotada para se conceituar bons antecedentes, a divulgação do conteúdo do registro alcança outros processos criminais, apesar da presunção constitucional de inocência, pois existem posições na doutrina e jurisprudência que consideram portador de maus antecedentes quem ostentar em nome próprio inquéritos policiais arquivados. ${ }^{446}$

O emprego variado e a visão multiforme dos antecedentes criminais recomendam sua detida análise, especialmente porque as informações que são consideradas a título de

\footnotetext{
${ }^{444}$ VEIGA, Catarina, op. cit., p. 24. A referência bibliográfica da obra, cujo trecho foi traduzido livremente pela autora citada, é a seguinte: "Dworkin, Ronald. A Mater of Principle, Harvard University Press, Cambridge, Massachussets, 1985, p. 72 e seguintes."

${ }^{445}$ GROSSO GALVAN, Manuel, op. cit., p. 21 e 24-25.

${ }^{446}$ FERNANDES, Antonio Scarance. A reação defensiva à imputação. São Paulo: RT, 2002. p. 128-129.
} 
antecedentes, freqüentemente, são fornecidas pelo registro criminal. Aliás, é importante ressaltar que o registro criminal não admite lançamento de anotações meritórias e, ${ }^{447}$ portanto, nele não se deveria permitir a inscrição e manutenção de anotações pejorativas se elas não servem para conferir ao acusado a condição de reincidente ou portador de maus antecedentes.

Defender que as decisões não-condenatórias inseridas no registro criminal devem ser consideradas em prejuízo do acusado ${ }^{448}$ não é postura adotada neste trabalho por entender-se que a presunção constitucional de inocência afasta essa possibilidade e impede, por exemplo, a imposição de pena mais rigorosa qualitativa ou quantitativamente ${ }^{449}$ e a restrição de benefícios na fase da execução da pena. Aliás, funda-se na impossibilidade dessa apreciação a idéia de propor o cancelamento desses dados do registro criminal depois de transcorrido determinado lapso temporal sem notícia de outros envolvimentos da pessoa com a prática de crimes.

Abrigado pelo princípio da presunção de inocência, Alberto Zacarias Toron admite que "os antecedentes do acusado, do ponto de vista de registros policiais e judiciais, só se considerarão maculados quando houver decisão transitada em julgado. Dessa forma, não se poderá computar o mero registro de inquéritos e ações penais em folha de antecedentes". 450 Essa posição concilia a necessidade da anotação da informação no registro criminal e restringe sua utilização sistemática em prejuízo do acusado.

Em Portugal, foi afirmado não parecer conveniente permitir a inscrição no cadastro criminal referente à determinada pessoa de decisão judicial que não avaliou a culpa do acusado, porque a divulgação dessa informação não é essencial e indispensável à justiça e,

\footnotetext{
${ }^{447}$ BISSOLI FILHO, Francisco, op. cit., p. 64.

${ }^{448}$ BITENCOURT, Cezar Roberto. Manual de direito penal: parte geral. 4. ed. São Paulo: RT, 1997. p. 529. $\mathrm{O}$ autor entende que inquéritos com decisões absolutórias, processos em andamento, absolvições por insuficiência de provas, prescrições abstratas, retroativas e intercorrentes devem ser analisados a título de "antecedentes criminais", pois não considerá-los seria "rematado equívoco", porque ao se admitir tais situações, como antecedentes negativos, não se faz novo juízo de censura.

449 Confira-se, a propósito, a ementa do acórdão a seguir transcrita: "Direito Penal. Habeas Corpus. Receptação. Dosimetria da pena. Reincidência. Circunstâncias judiciais. Afastamento. Pena mínima e regime inicial aberto. 'Não podem militar em desfavor do réu procedimentos arquivados e processos penais em curso. Ordem concedida para, mantida a condenação e a pena de multa, reduzir a reprimenda privativa de liberdade para um ano de reclusão, em regime inicial aberto.' (STJ - 6 ${ }^{\mathrm{a}} \mathrm{T}-\mathrm{HC}$ 47.774/MS - rel. Maria Thereza de Assis Moura - j. 30.10.07 - DJU 26.11.07, p. 248-249).” Além desse julgado, foi considerado que: "É entendimento pacífico nesta Corte de Justiça que, como maus antecedentes criminais, por força de dispositivo constitucional (art. 5\%, LVII, CRFB), tem-se a condenação transitada em julgado por delito anterior ao que se examina, excluídas aquelas que configuram reincidência (art. 64, I, CP) [STJ, AgRg no REsp 753419. rel. Min. Jane Silva, DJe 26.05.2008, edição n. 146, documento n. 3878407].”

${ }^{450}$ Op. cit., p. 74.
} 
além disso, pode produzir efeito duplamente incriminador. ${ }^{451}$

No Brasil, esse efeito é exacerbado e inevitável, pois o registro criminal também contém inscrição relacionada à existência de inquérito policial instaurado para apurar crime imputado à determinada pessoa, sem previsão da existência de meios simples para se alcançar o cancelamento do dado, por exemplo, no caso do arquivamento da investigação, conforme afirmou Antonio Scarance Fernandes no trecho antes transcrito.

Além disso, é importante ressaltar que aquilo que se convencionou chamar pessoa detentora de bons antecedentes, nada mais é que alguém cujo prontuário criminal está vazio sem qualquer anotação. A manutenção desse prontuário sem anotações, por dilatado período de tempo, permite considerar que a pessoa ostenta ótimos antecedentes.

Por outro lado, se existir anotação decorrente de decisão condenatória transitada em julgado relacionada à prática de crime anterior, será o suficiente para considerar a pessoa portadora de antecedentes no momento da avaliação dos seus antecedentes criminais. Duas ou mais condenações justificarão adjetivar tais antecedentes de maus, enquanto número maior de condenações permite falar em péssimos antecedentes.

Entretanto, é necessário dar oportunidade para a pessoa reverter essa situação impedindo que gravame dessa natureza recaia perenemente sobre alguém considerado portador de antecedentes criminais.

Ao aproximar as idéias relativas aos antecedentes à reincidência criminal, Francisco Bissoli Filho critica a normatização daquele instituto à luz deste, evidentemente diante da relação de gênero e espécie que guardam. $O$ autor não encontra justificativa para a legislação penal nacional deixar de aplicar o princípio da transitoriedade aos antecedentes criminais, conforme previsto para a reincidência, permitindo a influência perpétua dos antecedentes "na vida do indivíduo, mormente quando a sociedade, patrocinada por organismos estatais, procura organizar bancos de dados de infrações criminais, inclusive através de redes informatizadas, com possibilidade de acesso a inúmeros cidadãos" ${ }^{452}$

Adotar o critério da temporariedade para impedir que os efeitos negativos dos antecedentes criminais se perenizem, sem modificação do conteúdo do registro criminal, é idéia também defendida por Alberto Zacarias Toron, ao questionar o cabimento da prescrição dos antecedentes, levando em consideração acórdão que tratou desse tema. ${ }^{453}$

${ }^{451}$ VEIGA, Catarina, op. cit., p. 68.

452 Op. cit., p. 24.

453 "Outra questão importante está em saber se o fato de alguém um dia ter sido condenado há mais de cinco 
Anota-se, que caso os antecedentes criminais extraídos do registro, em determinadas situações, favorecerem o acusado, este ou alguém em seu nome poderá requerer certidão comprobatória dessa informação mesmo se ela estiver cancelada por decisão judicial. Em determinados casos, durante a tramitação do processo penal, poderá ser importante conhecer a existência de outros fatos ligados ao crime sob apuração, eventualmente analisados em outros processos, como ocorre nos casos em que há conexão e crime continuado. ${ }^{454}$

Por fim, considera-se necessário adotar critério objetivo para apontar determinada pessoa como portadora de antecedentes criminais, extraindo-se tal conclusão da presença de anotação no registro criminal que aponte existir condenação criminal anterior transitada em julgado, sem configurar reincidência. Entender que aquele que ostenta antecedentes pode ser considerado portador de maus ou péssimos antecedentes exige contabilizar o número de situações que geram tal condição, pois quem possui uma anotação que resultar em antecedentes deve ser considerado diversamente daquele que possui duas e do outro que ostenta três ou mais anotações. Cabe, também, fixar espaço de tempo razoável para o emprego desse dado, visando impedir a perenização da sua manutenção em arquivo e a exposição daquele que ostenta a anotação por lapso temporal indefinido.

\subsection{Interrogatório e registro criminal}

Ao iniciar o estudo deste tema, é interesse observar a redação atual do caput e o parágrafo $1^{\circ}$ do artigo 187 do Código de Processo Penal, a partir da Lei $n^{\circ} 10.792$, de $2003,{ }^{455}$ e compará-la ao texto original do artigo 188 dessa lei que dispunha sobre o mesmo

anos e, portanto, tecnicamente primário, deverá ser eternamente considerado portador de maus antecedentes? Recente jurisprudência do Superior Tribunal de Justiça indica que não. Com efeito, o Min. Vicente Cernicchiaro, em acórdão não unânime da $6^{\mathrm{a}}$ T., deixou assentado o seguinte: 'Direito penal. Reincidência. Antecedentes. O art. 61, I, do CP determina que, para efeito da reincidência, não prevalece a condenação anterior, se entre a data do cumprimento ou extinção da pena e a infração anterior houver decorrido período superior a cinco anos. O dispositivo se harmoniza com o Direito Penal e a Criminologia modernos. O estigma da sanção criminal não é perene. Limita-se no tempo. Transcorrido o tempo referido, evidencia-se a ausência de periculosidade, denotando, em princípio, criminalidade ocasional. O condenado quita sua obrigação com a Justiça Penal. A conclusão é válida também para os antecedentes. Seria ilógico afastar expressamente a agravante e persistir genericamente para recrudescer a sanção aplicada.' (Recurso em Habeas Corpus $\mathrm{n}^{\mathrm{o}}$ 2.227-2/MG, Brasília, DF, 18 de dezembro de 1992. Diário Oficial [da] República Federativa do Brasil, Brasília, DF, 29 mar. 1993, p. 5268 apud TORON, Alberto Zacarias, op. cit., p. 74.)"

${ }^{454}$ VEIGA, Catarina, op. cit., p. 122.

455 “Art. 187 - O interrogatório será constituído de duas partes: sobre a pessoa do acusado e sobre os fatos. $\S 1^{\circ}-\mathrm{Na}$ primeira parte o interrogando será perguntado sobre a residência, meios de vida ou profissão, oportunidades sociais, lugar onde exerce a sua atividade, vida pregressa, notadamente se foi preso ou processado alguma vez e, em caso afirmativo, qual o juízo do processo, se houve suspensão condicional ou 
tema. $^{456}$

A redação em vigor do parágrafo $1^{\circ}$ do artigo 187 do Código de Processo Penal indica que serão dirigidas ao acusado perguntas sobre sua vida pregressa, se foi ou não preso ou processado, se foi submetido a processo regular ou se houve suspensão do seu andamento e, ainda, se cumpriu pena, ou seja, inovou em relação ao dispositivo anterior.

No texto revogado, o artigo 188 do Código de Processo Penal dispunha que o acusado seria cientificado da acusação e interrogado, devendo-se indagar-lhe previamente o nome, naturalidade, estado, idade, filiação, residência, meios de vida ou profissão, lugar onde exerce atividade e se sabe ler e escrever.

Assim, entre as alterações trazidas pela Lei $\mathrm{n}^{0}$ 10.792, de 2003, relativas ao interrogatório, aquela que interessa discutir no presente estudo é a obrigação de o acusado responder, antes do início do interrogatório de mérito, as perguntas relacionadas não apenas à sua qualificação pessoal, mas também à sua vida pregressa. ${ }^{457}$

Enfatiza-se que o $\S 1^{\circ}$ do artigo 187 do Código Penal dispõe seja indagado pelo juiz ao acusado se foi preso ou processado alguma vez e, em caso afirmativo, qual o juízo do processo, se houve suspensão condicional ou condenação, qual a pena imposta e se a cumpriu. Ao responder tais indagações, o acusado não fornecerá somente dados relativos à vida pregressa, ligados à conduta social, mas dará informes reveladores dos seus antecedentes criminais em afronta ao direito de manter silêncio sobre fatos e situações que poderão ser prejudiciais à sua defesa.

condenação, qual a pena imposta, se a cumpriu e outros dados familiares e sociais.

$\S 2^{\circ}$ - Na segunda parte será perguntado sobre:"

${ }^{456}$ Redação anterior: "Art. 188 - O réu será perguntado sobre o seu nome, naturalidade, estado, idade, filiação, residência, meios de vida ou profisssão e lugar onde exerce a sua atividade e se sabe ler e escrever, e, depois de cientificado da acusação, será interrogado sobre:"

457 " O direito ao silêncio, no momento do interrogatório, é limitado quanto à sua extensão mas não quanto à sua profundidade [...] o direito ao silêncio limita-se, apenas, à última parte do ato de interrogatório, mas, nesta, seu exercício é pleno, não encontrando limites, porque assegurado pela Constituição da República. $\mathrm{O}$ direito ao silêncio não pode ser invocado pelo interrogado como motivo para deixar de responder às perguntas referentes à sua qualificação (art. 188 do CPP), ou, ainda, para mentir sobre elas, por três motivos: primeiro, porque tais respostas não trazem em si qualquer atividade defensiva; segundo, porque a exata qualificação do interrogado evita confusões acerca de sua identidade; e, terceiro, porque a mentira que se permite é aquela de que se vale o interrogado para defender-se quanto aos fatos que lhe são imputados" (MOURA, Maria Thereza Rocha de Assis; MORAES, Maurício Zanoide. Direito ao silêncio no interrogatório. Revista Brasileira de Ciências Criminais, RT, São Paulo, n. 6, p. 138, abr.jun. 1994). O artigo jurídico mencionado foi escrito antes da edição da Lei ${ }^{\circ}$ 10.792, de 2003, que introduziu no Código de Processo Penal várias alterações no capítulo que trata do interrogatório do acusado. Entretanto, a afirmação dos autores no trecho transcrito é irretocável e atual no que tange ao chamado interrogatório de qualificação ou sobre a pessoa do acusado, mantido pela redação vigente do artigo $187, \S 1^{\circ}$, do Código de Processo Penal. Antes dessa alteração ao juiz não cabia indagar ao acusado sobre sua vida pregressa na primeira parte do interrogatório, mudança introduzida pela legislação modificadora do interrogatório em vigor a partir de 2003. 
O acusado não está obrigado a responder as questões supramencionadas, mas se o fizer, não estará compelido a dizer a verdade e, ainda, ao recusar-se a respondê-las sua negativa não poderá ser usada contra ele sequer para demonstrar, por exemplo, que o acusado não esclareceu a verdade sobre seus antecedentes criminais.

Se "o silêncio do acusado, na ótica da Constituição, assume dimensão de verdadeiro direito, cujo exercício há de ser assegurado de maneira plena, sem poder vir acompanhado de pressões, diretas ou indiretas, destinadas a induzir o acusado a prestar depoimento", 458 levando em consideração a posição da Professora Ada Pellegrini Grinover é possível estender à parte introdutória do interrogatório legítima autorização ao acusado não responder indagações feitas pelo juiz, se ao respondê-las estiver obrigado a fornecer respostas auto-incriminantes ou lesivas à sua dignidade, conforme interpretação feita a partir de critério teleológico e sistemático da disciplina do interrogatório adotada no Brasil a partir da Lei $n^{\mathrm{o}} 10.792$, de $2003{ }^{459}$

Avançando o raciocínio, também é possível considerar que se o direito ao silêncio também é aplicável à primeira parte do interrogatório do acusado tão-somente em relação às indagações referentes à vida pregressa que possam obrigá-lo a expor ao juiz informações acerca dos seus antecedentes criminais, caso o acusado se omitir e nada falar sobre tais informes, parece que não cometerá crime algum, porque inexiste norma penal que incrimine e puna, especificamente, essa conduta.

Não é possível considerar que os dados do registro criminal integrem, em sentido amplo, a identidade da pessoa para indicar que ocorreu falsa identidade prevista no artigo 307 do Código Penal.

Poder-se-ia imaginar que o acusado que omite a verdade ou declara falsamente fatos relacionados aos seus antecedentes criminais quando indagado sobre eles no início do ato

${ }^{458}$ GRINOVER, Ada Pellegrini; FERNANDES, Antonio Scarance; GOMES FILHO, Antonio Magalhães. As nulidades..., cit., p. 97.

459 "Pensamos - e já escrevemos neste sentido - que o interrogatório que constitui manifestação de autodefesa, acobertado por isto pelo direito ao silêncio, é em princípio o interrogatório sobre os fatos ( $\S 2^{\circ}$ do art. 187). Nenhum exercício de defesa parece conter-se na simples qualificação do acusado. Ocorre, porém, que o interrogatório sobre a pessoa do acusado, previsto no $\S 1^{\circ}$ do art. 187 do CPP, inclui a solicitação de informações sobre residência, meios de vida ou profissão, oportunidades sociais, lugar onde exerce atividades, vida pregressa, se foi preso ou processado (com indicação do juízo do processo, a informação a respeito da condenação, imposição e cumprimento de pena ou suspensão condicional da penal) e outros dados familiares e sociais. Essas informações podem ser auto-incriminantes ou, ao menos, configurar lesão à dignidade do acusado. Elas também só podem ser prestadas espontaneamente. Se houver recusa a falar, também aqui estará o acusado exercendo seu legítimo direito ao silêncio. Observe-se que esta não é apenas a interpretação teleológica do dispositivo, mas também sistemática, uma vez que o direito ao silêncio vem garantido genericamente no art. 186, anterior ao art. 187.” GRINOVER, Ada Pellegrini. O interrogatório como meio de defesa (Lei 10.792/2003). Revista Brasileira de Ciências Criminais, RT, São Paulo, n. 53, p. 188, mar./abr. 2005. 
de interrogatório, conforme traça a normatização do artigo 187 do Código de Processo Penal, pode sofrer a sanção prevista no artigo 299 do Código Penal que trata da falsidade ideológica. Entretanto, referido raciocínio parece não se sustentar pelo fato de a omissão ou a falsidade da declaração não alterar a verdade sobre fato juridicamente relevante, porque se o acusado estiver corretamente identificado, os dados relativos aos seus antecedentes criminais podem ser facilmente obtidos pela polícia ou justiça.

Não há paralelismo entre a norma processual penal que obriga o acusado a revelar dados relativos aos seus antecedentes criminais e outra de natureza penal que o puna pela omissão ou declaração falsa de seus antecedentes criminais durante o interrogatório, providência outrora prevista pela legislação portuguesa, conforme adiante exposto.

Esse paralelismo, aliás, é encontrado entre o artigo 207 do Código de Processo Penal que proíbe o testemunho de pessoas que, em razão de função, ministério, ofício ou profissão devam guardar segredo, que desobrigadas pelo interessado desejarem depor, e o artigo 154 do Código Penal que pune com pena de 3 (três) meses a 1 (um) ano de detenção e multa a revelação, sem justa causa, de segredo conhecido em razão de função, ministério, ofício ou profissão, e cuja revelação possa produzir dano a outrem.

Finalmente, o silêncio do acusado para responder questionamentos da autoridade policial ou judicial acerca de dados da sua vida pregressa relacionados aos próprios antecedentes criminais não configurará crime de desobediência. Inadmissível a caracterização do mencionado delito pelo exercício do direito de não se auto-incriminar mediante recusa de prestar-se a colaborar para produção de prova contra a própria pessoa, efeito que pode ser extraído das respostas do acusado fornecidas ao juiz na primeira parte do interrogatório quando, por exemplo, não admite ter sofrido prisão anterior, processo ou condenação posteriormente comprovados por informação ofertada pelo registro criminal. ${ }^{460}$

A possibilidade de o acusado omitir referências às decisões canceladas no registro criminal perante o tribunal já foi considerada em Portugal como posicionamento que se harmoniza com as modernas tendências legislativas, tratando de verdadeira faculdade da qual ele poderá ou não abrir mão, avaliado o seu interesse, porque poderá servir para prova

\footnotetext{
${ }^{460}$ Antonio Scarance Fernandes (Processo..., cit., p. 279) não aborda diretamente a questão sob enfoque, mas indica que o exercício do direito de não se auto-incriminar permite ao acusado recusar colaboração para produzir prova contra sua própria pessoa. Nesse trecho da obra, o autor refere-se a julgado (Supremo Tribunal Federal. Habeas Corpus $\mathrm{n}^{\mathrm{o}}$ 77.135/SP, Relator: Ministro Ilmar Galvão, Brasília, DF, 8 de setembro de 1998. Informativo STF, Brasília, n. 122, p. 1) no qual foi assentado que o não-fornecimento de padrões gráficos de próprio punho para instruir investigação acerca de crime de falsificação de documento, diante do que dispõe o artigo 174, inciso IV, do Código de Processo Penal, "não obriga o indiciado fornecer prova para caracterizar sua própria culpa, mas apenas determina a intimação deste para, querendo, fornecê-la".
} 
de sua inocência relativamente ao fato que se pretende demonstrar. ${ }^{461}$

Nesse aspecto, para fundamentar ainda mais a afirmação feita, vale ressaltar que a possibilidade de o acusado não estar obrigado a declinar dados acerca dos seus antecedentes criminais decorre do princípio de defesa, abordado no número 1 do artigo $32^{\circ}$ da Constituição da República portuguesa, no qual são extraídos vários direitos e, entre eles, o direito de não ser interrogado sobre os seus antecedentes criminais. Não se impõe ao acusado, também, o dever de colaboração. ${ }^{462}$

Especificamente em relação à obrigação de o acusado informar ao juiz durante o interrogatório seus antecedentes criminais, é importante conhecer o tratamento dado pelo direito processual penal português ao tema. O número 2 do artigo $342^{\circ}$ do Código de Processo Penal português, de 1987, frisava que no começo da audiência de discussão e julgamento o argüido deveria responder perguntas sobre os seus antecedentes criminais com a seguinte redação: “dever de responder com verdade a perguntas feitas por entidade competente sobre a sua identidade e, quando a lei impuser, sobre os seus antecedentes criminais". Assim, o argüido responderia perguntas referentes a fatos sem ligação com o objeto do processo e não definidos na acusação contra ele formulada, permitindo fosse avaliado negativamente por impressões extraídas de sua "perigosidade criminal anterior e linha de conduta pessoal". 463

Ocorre que referida disposição processual foi revogada a partir de 3 de dezembro de 1995, data em que entraram em vigor algumas alterações, no Código de Processo Penal português, editadas para parificar a posição jurídica da acusação e defesa e também para "incrementar a igualdade de armas". Essa revogação, especificamente, foi fundada no entendimento que a indagação dos antecedentes criminais do argüido atentava contra sua dignidade e garantias constitucionais, buscando facultar-lhe "todas as garantias de defesa", para permitir fosse o argüido "tratado como sujeito e não objeto do processo" e para "salvaguarda da presunção de inocência até o trânsito em julgado da condenação". 464 Mencionada disposição processual revogada era acompanhada de norma material não

${ }^{461}$ COSTA, António Manuel de Almeida, op. cit., p. 353-354.

462 VEIGA, Catarina, op. cit., p. 42 e 44.

${ }^{463}$ Id., ibid., p. 46.

464 Referido artigo do Código de Processo Penal português (Disponível em: $<$ http://www.portolegal.com/CPPen.htm>. Acesso em: 13 set. 2008) está redigido do seguinte modo: “Artigo 342. ${ }^{\circ}$ : Identificação do arguido. 1 - O presidente começa por perguntar ao arguido pelo seu nome, fíliação, freguesia e concelho de naturalidade, data de nascimento, estado civil, profissão, local de trabalho e residência e, se necessário, pede-lhe a exibição de documento oficial bastante de identificação. 2 - O presidente adverte o arguido de que a falta de resposta às perguntas feitas ou a falsidade da mesma o pode fazer incorrer em responsabilidade penal." 
eliminada (artigo $359^{\circ}$, número 2, $2^{\mathrm{a}}$ parte, do Código Penal português) por meio da qual havia punição para a falsidade de depoimento ou de declaração relativas à declaração do argüido sobre seus antecedentes criminais. ${ }^{465}$

Embora essa alteração possa ter resultado em "eliminação infrutífera", porque não solucionou o problema da violação das garantias de defesa uma vez que continua possível ao juiz em Portugal conhecer os antecedentes criminais do argüido mediante análise do certificado de registro criminal que é anexado aos autos antes da audiência de discussão e julgamento dos fatos, permitiu fazer desaparecer aspectos vexatórios e estigmatizantes da obrigação imposta ao argüido de declarar, oralmente, perante o juiz que seria responsável por julgá-lo, os seus antecedentes criminais. ${ }^{466}$ A crítica que se faz em relação à questão trazida a lume não está relacionada ao modo de exteriorização dos antecedentes criminais do argüido no processo penal português, mas, sobretudo, ao momento que isso ocorre, pois a antecipação do conhecimento amplo dos dados do passado criminoso do argüido possibilita que essas informações sejam "susceptíveis de criar pré-juízos na avaliação do facto criminógeno". 467

Nota-se, portanto, que o efeito constatado no direito processual penal de Portugal relativo ao conhecimento dos antecedentes criminais a partir do interrogatório do acusado e o tratamento dado nesse país para referido aspecto servem como parâmetro para analisar a mesma situação no sistema processual penal brasileiro.

No Brasil, identicamente, o juiz poderá conhecer os antecedentes criminais do indiciado e acusado no início da investigação e do processo criminal por meio da juntada de documentos, mas o direito a não auto-incriminação deveria orientá-lo não exigir do interrogado respostas que servissem para conferir os antecedentes criminais. Além disso, pelas idéias expostas, inexiste condição de responsabilizar o acusado penalmente ou usar a informação relativa ao silêncio ou à resposta mentirosa acerca dos seus antecedentes criminais colhida no interrogatório para prejudicá-lo.

\footnotetext{
${ }^{465}$ VEIGA, Catarina, op. cit., p. 47-49.

${ }^{466}$ Corroborando a idéia de que a eliminação da possibilidade de a Justiça tomar conhecimento dos antecedentes do infrator é parcial, necessário apontar que, durante o primeiro interrogatório realizado pelo juiz de instrução, este deverá indagar do interrogando acerca de eventuais condenações anteriores, conforme dispõe o artigo $141 .^{\circ}$, número 3 , do Código de Processo Penal português (cit.): "o arguido é perguntado pelo seu nome, filiação, freguesia e concelho de naturalidade, data de nascimento, estado civil, profissão, residência, local de trabalho, se já esteve alguma vez preso, quando e porquê e se foi ou não condenado e por que crimes, sendo-lhe exigida, se necessário, a exibição de documento oficial bastante de identificação. Deve ser advertido de que a falta de resposta a estas perguntas ou a falsidade das mesmas o pode fazer incorrer em responsabilidade penal."

${ }^{467}$ VEIGA, Catarina, op. cit., p. 51-54.
} 


\subsection{Execução penal e registro criminal}

No campo da execução penal, verifica-se a importância e a hierarquização dos antecedentes criminais para o exame da personalidade do condenado, pois eles ocupam papel preponderante para a classificação prévia ao cumprimento da sanção privativa de liberdade imposta. ${ }^{468}$

É possível visualizar pontos comuns entre o registro criminal e a execução da pena ao observar, inicialmente, que a Lei $\mathrm{n}^{0} 7.210$, de 1984, que trata da execução penal, fixa como objetivos:

a) alcançar a efetivação das disposições de sentença ou decisão criminal;

b) proporcionar condições para a harmônica integração social do condenado ou do internado. Os dois objetivos traçados pela Lei de Execução Penal relacionam-se com os antecedentes criminais reunidos no registro.

Ao buscar-se a efetivação das disposições da sentença judicial e impor-se o cumprimento da sanção, é importante a prévia classificação do condenado mediante realização de exame criminológico conforme previsão do artigo 34 do Código Penal e, especialmente, do artigo $5^{\circ}$ da Lei de Execução Penal. O condenado submetido ao cumprimento de pena privativa de liberdade em regime fechado será classificado para orientar a individualização da execução penal, de acordo com os seus antecedentes e personalidade, providência que é facultada no caso de impor-se regime semi-aberto conforme disposição legal. ${ }^{469}$

A Comissão Técnica de Classificação é encarregada de elaborar o exame criminológico. Ao exercer essa tarefa, seus membros utilizarão peças e informações do processo de execução, nos termos do artigo $9^{\circ}$ da mencionada Lei de Execução Penal, debruçando-se, evidentemente, sobre dados que farão emergir informações relacionadas aos antecedentes criminais do condenado referido nesses documentos.

A análise e o encontro de antecedentes criminais extraídos do registro importará na adoção de providências diversas em relação ao modo de os condenados cumprirem suas penas. Impõe-se, então, tratamento penitenciário menos rigoroso àqueles cujos antecedentes não sejam desabonadores, devendo o primário, inclusive, cumprir pena em seção prisional distinta daquela reservada aos reincidentes nos estabelecimentos em que estiverem

${ }^{468}$ GROSSO GALVAN, Manuel, op. cit., p. 98 e 100.

${ }^{469}$ Artigo $8^{\circ}$ da Lei de Execução Penal. 
recolhidos. ${ }^{470}$

Aliás, segundo Francisco Bueno Arús, conhecer a personalidade do condenado é fundamental para o sucesso de várias regras próprias da fase de execução da pena. ${ }^{471}$

Cumpre salientar que a Lei de Execução Penal foi alterada para permitir a sujeição ao denominado regime disciplinar diferenciado do preso em relação ao qual recaiam fundadas suspeitas de envolvimento ou participação, a qualquer título, em organizações criminosas, quadrilha ou bando, ${ }^{472}$ medida que conta com objeções, especialmente, pela ausência de previsão legal acerca do conceito de organização criminosa ou de crime organizado no Brasil. O envolvimento do condenado com a criminalidade organizada poderá ser conhecido por meio do exame dos documentos encartados no processo de execução penal, mas também pelas informações extraídas dos antecedentes criminais inseridos no registro criminal do condenado.

Não somente o envolvimento do condenado com a criminalidade violenta e organizada justifica aos órgãos responsáveis pelo cumprimento e fisscalização da pena acessarem dados do registro criminal, mas a simples inserção do preso no estabelecimento penitenciário. $^{473}$

Nota-se o realce que é dado ao conteúdo do registro criminal no momento de individualizar o cumprimento da pena, tanto que já foi afirmado que as informações sobre o passado e a biografia do condenado se apresentam como elementos indispensáveis para "individualizar a pena ao máximo". 474

Essa biografia do condenado, segundo Foucault, espécie de "boletim individual de modelo uniforme em todas as prisões", acompanhará "o detento do tribunal à prisão". 475

\footnotetext{
${ }^{470}$ Artigo 84, parágrafo $1^{\circ}$, da Lei de Execução Penal.

471 "El conocimiento de la personalidad de condenado, y en consecuencia de cuantos antecedentes sobre su personalidad y modo de ser y de vivir se pueden recopilar, es fundamental para el éxito de reglas como las relativas a la separación, clasificación, régimen (educación, trabajo, permisos de salida), grados de tratamiento penitenciario (inspirado en el principio de individualización científica art. 72, de la LOGP), liberdad condicional y asistencia social postpenitenciaria (itálico original)." (Op. cit., p. 59).

${ }^{472}$ Artigo 52, parágrafo $2^{\circ}$, da Lei de Execução Penal, alterado pela Lei n ${ }^{\circ} 10.792$, de 2003.

${ }^{473}$ Razão assiste a Francisco Bueno Arús (op. cit., p. 59) ao afirmar que a necessidade de conhecimento das peculiaridades de cada condenado interessa "tanto al personal de los establecimientos penitenciarios (directivo, técnico e auxiliar) como a los Jueces de Vigilancia Penitenciaria, por lo que ni el régimen más estricto de acceso al Registro de Antecedentes Penales pude prohibir el acceso de las autoridades y funcionarios mencionados a los efectos que se indican."

${ }^{474}$ GROSSO GALVAN, Manuel, op. cit., p. 97.

${ }^{475}$ FOUCAULT, Michel. Vigiar e punir. 32. ed. Tradução de Raquel Ramalhete. Petrópolis: Vozes, 1987. p. 210-211. Nesse trecho da clássica obra na qual o autor analisa o nascimento da prisão, ao dizer que "o delinqüente se distingue do infrator pelo fato de não ser tanto seu ato, quanto sua vida o que mais o caracteriza", Foucault permite entender que a biografia do condenado é documento mais abrangente que o registro de antecedentes criminais, pois congrega observações feitas a respeito da cada detento pelo diretor ou
} 
Depois de pesquisar e examinar os antecedentes inseridos no registro criminal para efetivar a decisão judicial, outra preocupação da Lei de Execução Penal é a integração social do condenado, objetivo também relacionado às informações depositadas no registro criminal, pois há estreita ligação entre a ressocialização e a consulta aos dados criminais.

A discutida ressocialização do condenado que cumpre pena privativa de liberdade merece ser compreendida dentro do contexto da redução dos efeitos colaterais da pena. Acerca da ressocialização, assunto que toca o tema objeto deste estudo, cabe ressaltar que "não representa perigo algum, senão ao contrário uma certa intenção de dulcificar ou humanizar as instituições penitenciárias" que não conseguiram alcançar o fim pretendido da recuperação do condenado para a sociedade, providência que exigiria alteração total dos valores sociais e mudança drástica do tratamento dos antecedentes criminais. ${ }^{476}$

No Brasil, a disposição que pretende fazer cumprir essa tarefa em relação ao cadastro de antecedentes se encontra no artigo 202 da Lei de Execução Penal, dispositivo de evidente caráter ressocializador e impregnado da nítida intenção de proporcionar harmônicas condições de integração social ao condenado e ao internado conforme preleciona o artigo $1^{\circ}$ desse texto legal.

O reflexo causado pelo antecedente criminal, última conseqüência da condenação, poucas vezes é imaginado pelo criminoso e talvez pelo próprio julgador, pois ambos, ao seu modo respectivo, normalmente não visualizam ser o registro que a condenação gerará uma espécie de marca que acompanhará o condenado por sua vida inteira.

A anotação do antecedente no registro individual de determinada pessoa causará conseqüências, mais ou menos graves, para sua vida futura. O registro exerce influência, negativamente, na sua vida mesmo depois de cumprida ou extinta a pena. ${ }^{477}$ Esse efeito é sentido especialmente no campo social, jurídico e profissional e, apesar de não estar

chefe dos guardas, pelo sacerdote e pelo professor, enfim, todos envolvidos de algum modo em vigiar, controlar ou assistir o condenado. Francisco Bissoli Filho (op. cit., p. 195) indica também que "a biografia é um importante elemento de identificação pessoal, uma vez que cada indivíduo somente pode ter uma. É através dela que se pode estruturar a sua história."

${ }^{476}$ GROSSO GALVAN, Manuel, op. cit., p. 389-390.

$477 \mathrm{Na}$ Espanha, a Ley Orgánica General Penitenciaria $n^{\circ} 1 / 1979$, de 26 de septiembre, ao tratar da assistência pós-penitenciária, dispôs que os antecedentes não poderão ser em nenhum caso motivo de descriminação social ou jurídica (GROSSO GALVAN, Manuel, op. cit., p. 94). Referido trecho da lei, a seguir transcrito, foi classificado de "belo", mas na prática reduzida a uma "declaração de princípios":

"Artículo setenta y três

Uno. El condenado que haya cumplido su pena y el que de algún otro modo haya extinguido su responsabilidad penal deben ser plenamente reintegrados en el ejercicio de sus derechos como ciudadanos.

Dos. Los antecedentes no podrán ser en ningún caso motivo de discriminación social o jurídica."

Idêntica crítica é feita por Francisco Bueno Arús (op. cit., p. 20) ao afirmar que o mesmo artigo da Ley Orgánica Penitenciaria "hace una declaración solemne en el terreno de los principios, pero carente de consistencia." 
previsto em lei e determinado pela decisão judicial condenatória, trata-se de reflexo silencioso da condenação que repercute na esfera social e profissional do ex-condenado com o fim de satisfazer a defesa e a proteção da sociedade. ${ }^{478}$

Mesmo no momento do cumprimento ou execução da pena, a importância do registro criminal não é reduzida, porque se faculta o acesso aos dados do registro à autoridade judicial e administrativa, encarregada de fazer cumprir essa tarefa visando permitir-lhe ações para individualizar o cumprimento da pena. ${ }^{479}$

A utilidade do registro criminal é uma característica não contestada neste trabalho, porque ele é considerado como instrumento útil para aferir a reiteração da atividade criminosa e para identificar os detentores de personalidade freqüentemente violadora da norma penal, apesar das pretéritas advertências recebidas pelas decisões judiciais escoradas no ordenamento jurídico e impregnadas de mensagens sobre a inadequação dessas condutas. ${ }^{480}$ Embora útil, inegável, também, que o registro funcione como obstáculo real à reinserção social e profissional do condenado que cumpriu a pena, cabendo ao Estado posicionar-se claramente para reduzir, dentro do possível, esses efeitos negativos.

O registro criminal ocupa o papel de controle do criminoso além dos limites estabelecidos pelo cumprimento da pena. Ele também serve como uma espécie de "modelador" da sociedade pelos seguintes motivos:

a) comprova eficácia da pena;

b) reproduz a delinqüência socialmente necessária;

c) facilita o aumento da repressão aos setores que mostrem especial resistência ao cumprimento das leis. ${ }^{481}$

Essas características permitem verificar a perversidade e complexidade do registro criminal, instituto que não deve simplesmente ser extirpado, mas que exige sérias alterações que reduzam seu efeito estigmatizante e criminógeno.

Parece correto dizer que o registro criminal é uma espécie de "mal necessário". Isso não significa admitir que o instituto deva permanecer estagnado, sem aperfeiçoarem-se os seus mecanismos, especialmente, pela redução das inscrições nele lançadas as quais deveriam restringir-se ao necessário e útil para o desempenho da tarefa de proteção da

\footnotetext{
${ }^{478}$ VEIGA, Catarina, op. cit., p. 93.

${ }^{479}$ GROSSO GALVAN, Manuel, op. cit., p. 289.

${ }^{480}$ VEIGA, Catarina, op. cit., p. 94.

${ }^{481}$ GROSSO GALVAN, Manuel, op. cit., p. 5-6.
} 
sociedade. Nesse aspecto, as idéias de eficiência e garantismo mostram-se convenientes para orientar o emprego e a regulação do registro, cujas características o tornam semelhante à droga farmacológica, pois embora o medicamento seja indispensável no combate de certas doenças, os pesquisadores procuram, continuamente, reduzir-lhe os efeitos negativos. Esse procedimento deveria ser transferido para o campo do registro criminal e orientar a interpretação e as discussões relativas ao tema, permitindo que as informações necessárias para o conhecimento do passado criminal da pessoa estejam corretas e facilmente acessíveis ao juiz, mas não sejam por ele interpretadas exclusivamente no aspecto negativo, em especial quando essa interpretação não é feita em conformidade com a lei penal e processual, tal qual ocorre nos casos em que juízes e tribunais consideram inquéritos arquivados e processos sem resultado condenatório como configuradores de maus antecedentes criminais.

A visível contradição entre o fim ressocializador da pena e o registro criminal deve servir como ponto para reflexão, porquanto não é possível permitir que ao lado de cumprir a tarefa de informar os antecedentes da pessoa submetida ao julgamento ele dificulte a reincorporação do condenado à vida normal. ${ }^{482}$

A comprovação da condição de não-reincidente em crime doloso e portador de bons antecedentes para fins de requerer a concessão do livramento condicional, tratado no artigo 83 do Código Penal, requer acesso aos dados do registro criminal. Essa concessão exige a comprovação de quantidade de pena cumprida, dependendo da condição subjetiva do condenado, também regulada pelo mencionado artigo do Código Penal.

A respeito do livramento condicional já foi mencionado que o cumprimento de parcela da pena indica aptidão para convivência harmônica. Isso resulta em desnecessidade de defesa social e permite não seja anotada a situação em certidões do registro criminal expedidas para fins administrativos e particulares, exceto no que toca às eventuais incapacidades e interdições. ${ }^{483}$

Ao liberado condicional, o Código Penal brasileiro exige a comprovação de aptidão para promover a própria subsistência mediante trabalho honesto, devendo ser concedido prazo razoável para iniciar esse trabalho, pois se a dificuldade de obtê-lo atinge o cidadão incólume, muito mais o liberado que traz consigo a "indelével marca do cárcere". Em relação àquele que cumpriu a pena e o liberado condicional também já foi dito que o

${ }^{482}$ GROSSO GALVAN, Manuel, op. cit., p. 14.

${ }^{483}$ COSTA, António Manuel de Almeida, op. cit., p. 305-307. 
"estigma carcerário carregado pelo egresso é fator suficiente para dificultar-lhe a obtenção de emprego". Ainda no campo da reinserção do ex-condenado, cabe ressaltar a exigüidade do prazo de concessão de assistência ao egresso, pois o artigo 25 , inciso II, da Lei $\mathrm{n}^{\circ} 7.210$, de 1984, concede 2 (dois) meses, prorrogáveis uma única vez, por igual período, no qual é possível conceder auxílio material àquele que foi recentemente liberado do sistema penitenciário, lapso temporal considerado insuficiente para que a pessoa alcance meios dignos para sustentar-se. ${ }^{484}$

Finalmente, depois de referir-se ao livramento condicional e ao trabalho do liberado e do egresso, cabe discorrer, resumidamente, sobre as faltas disciplinares praticadas pelos condenados.

Essas infrações ao regime fixado e à disciplina imposta no ambiente carcerário, ao seu modo, ficarão registradas nos prontuários individuais de cada condenado, exercendo função semelhante ao registro criminal, tal qual uma "versão limitada" dele em relação às faltas disciplinares, porém não por isso "carente de repercussão no sistema penitenciário". A constatação da falta, a imposição de sanção disciplinar e as anotações dos incidentes nos prontuários dos presos servem não-somente para apurar, punir e desestimular $\mathrm{o}$ cometimento das faltas, sobretudo para diferenciar os condenados, papel desempenhado com especial ênfase pela existência dos antecedentes. ${ }^{485}$

A equação entre execução penal e registro criminal deve resultar na busca dos objetivos da execução, ou seja, efetivar as disposições da sentença ou decisão criminal e proporcionar condições para a integração social do condenado sem desguarnecer os interesses da sociedade.

${ }^{484}$ BRITO, Aléxis Augusto Couto de. Execução penal. São Paulo: Quartier Latin, 2006. p. 132 e 343.

${ }^{485}$ GROSSO GALVAN, Manuel, op. cit., p. 102-103. 


\section{CANCELAMENTO DO REGISTRO}

\subsection{Cancelamento, eliminação e valor histórico do registro criminal}

Reduzir-se o efeito estigmatizante da publicidade do registro criminal pela adoção de regras limitadoras para a expedição dos certificados ${ }^{486}$ é idéia anteriormente defendida neste trabalho e especialmente tratada no capítulo que cuidou do acesso ao registro. Entretanto, fixar limites para expedir certificados nem sempre é suficiente para proteger informações que devam ser mantidas sob reserva.

É possível agir de dois outros modos para restringir o acesso ao conteúdo do registro criminal e evitar a divulgação dos dados. Um deles exige a aferição do status daquele que deseja obter a informação, seguida da possibilidade da recusa, caso o requerente não esteja sequer habilitado a pleitear a informação. $O$ outro consiste em afastar as anotações do registro. Esses modos de ação não se repelem, ao contrário, complementam-se.

Impor sanção administrativa e penal àqueles que, indevidamente, busquem acessar ou divulgar dados extraídos do registro criminal também é providência importante para dar segurança e confiabilidade ao sistema. Essa forma de proteção, pela natureza administrativa e penal que ostenta, não será objeto de análise neste trecho do estudo, pois já referida anteriormente, e agora a proposta é concentrar o debate no afastamento das informações do registro criminal pelo cancelamento e pela eliminação dos seus dados.

Afastar as anotações lançadas no registro criminal por meio do cancelamento e da eliminação dos dados, dentro das hipóteses previstas pela legislação, aceitas pela jurisprudência e referidas pela doutrina, é providência eficiente para restringir ou vedar a divulgação e a publicidade dos dados que, ao mesmo tempo, preserva direitos e garantias individuais, ${ }^{487}$ embora por vezes encontre resistência. ${ }^{488}$

\footnotetext{
${ }^{486}$ GROSSO GALVAN, Manuel, op. cit., p. 7.

487 Estendendo o raciocínio desenvolvido neste parágrafo, é importante anotar que Francisco Bueno Arús (op. cit., p. 115, 122 e 128) afirma que na Espanha o cancelamento dos antecedentes penais é procedimento de natureza administrativa. O autor segue asseverando que a difusão indevida da informação do Registro Central de Penados y Rebeldes e a sua utilização para o exercício de direitos contemplados pela lei, entre eles o mais significativo é o direito ao trabalho, "es infringir maliciosamente principios fundamentales de nuestra Constitución y de nuestro sistema penal."

${ }^{488}$ A Procuradoria-Geral de Justiça do Estado de São Paulo publicou no dia 17 de junho de 2005, no Diário Oficial do Estado (Poder Executivo, p. 33) o Aviso no 321/05-PGJ, de 14 de junho de 2005, comunicando a
} 
Aponta-se, logo de início, que o afastamento da informação, quando admissível, em regra, não deverá prejudicar possíveis pesquisas para fins estatísticos e de investigação científica, gerando efeitos no campo do acesso particular, administrativo e para fins processuais.

Existe diferença entre o cancelamento e a eliminação dos dados inseridos no registro criminal.

A primeira espécie do gênero afastamento dos dados do registro, o cancelamento, é ação que limita ou restringe a utilização dos dados, sem excluí-los do acervo compilado no registro criminal.

A segunda espécie, a eliminação, permite separar e destruir o material contido na ficha de antecedentes criminais. Em outras palavras, eliminar significa suprimir do registro as anotações que, por motivo específico, não devam ser mantidas; permite liberação do espaço físico, facilita o manuseio dos arquivos e evita possíveis equívocos interpretativos ao impedir consultar as informações que deixarão de existir.

Entre as duas modalidades, o cancelamento da anotação é a providência mais freqüentemente admitida para restringir a publicidade dos dados do registro criminal, pois ele amplia a privacidade, permite as pesquisas estatísticas e científicas e mantém a informação para atender, exclusivamente, consultas autorizadas e justificadas.

Permite-se eliminar dados do registro em determinados casos, por exemplo, se houver comprovação de erros ou inscrição indevida da anotação nos arquivos. Nessa hipótese, manter a anotação mostra-se providência desnecessária e, especialmente, ofensiva à privacidade, tanto que nessa situação não se justifica sequer preservá-la para fins de estudo estatístico e de investigação científica.

Neste ponto do estudo e sob o tema analisado, interessa ressaltar que não será buscada sinonímia entre cancelar ${ }^{489}$ e eliminar ${ }^{490}$, pois fazendo referência ao registro

aprovação da Tese $\mathrm{n}^{\circ}$ 212, do Setor de Recursos Extraordinários e Especiais Criminais, redigido da seguinte forma: "ANTECEDENTES CRIMINAIS - EXCLUSÃO DE DADOS DOS INSTITUTOS DE IDENTIFICAÇÃO - IMPOSSIBILIDADE. A lei assegura o sigilo dos cadastros criminais, nas hipóteses de arquivamento de inquérito, absolvição, reabilitação e extinção da punibilidade, salvo requisições judiciais ou casos expressos em lei. Tais dados, portanto, não podem ser excluídos dos terminais dos Institutos de Identificação."

489 "Cancelar (lat cancellare) vtd 1 Riscar (o que está escrito) para que fique sem efeito. 2 Declarar nulo ou sem efeito; invalidar. 3 Eliminar, excluir. 4 Dir Concluir, não mais prosseguir (um processo). Antôns (acepções 1, 2 e 3): restabelecer, restaurar" (itálico original). In: Dicionário Michaelis da língua portuguesa. Disponível em: <http://michaelis.uol.com.br/moderno/portugues/index.php?lingua=portuguesportugues\&palavra $=$ cancelar $>$. Acesso em: 22 set. 2008. 
criminal cada um desses verbos exterioriza conteúdo próprio e sentido específico.

Cancelar a informação inserida no registro criminal conduz à idéia de riscar, tornar sem efeito ou invalidar a anotação, restringindo drasticamente a possibilidade da sua divulgação. Eliminar, por sua vez, leva à compreensão de fazer desaparecer, suprimir, apagar ou fazer sair a anotação do registro, impedindo sua divulgação. ${ }^{491}$

O cancelamento do registro ainda permite a obtenção da informação, caso necessário resgatá-la, mas exigiria determinação judicial, ${ }^{492}$ enquanto a eliminação suprimiria o dado, sem possibilitar sua reconstituição.

Cada uma dessas ações, cancelar ou eliminar anotações do registro criminal, poderá produzir efeito positivo ou negativo, dependendo do ponto de vista. A opção por um ou outro mecanismo exige analisar a tendência político-criminal. Caso a finalidade seja preservar a privacidade daquele que tem dados criminais não-essenciais anotados no registro, é desejável eliminar essa informação, mas se há interesse na preservação do acervo, mesmo em relação a informações não-essenciais, é recomendável cancelar a anotação, preservando-a para atender futura e eventual busca com autorização judicial.

Entretanto, o cabimento de cada uma delas deveria ser expressamente normatizado, ressalvada a possibilidade de o registro cancelado ser eliminado, mediante condições.

O tema sob análise conduz, necessariamente, à reflexão acerca do destino das anotações afastadas do registro criminal. Canceladas, serão mantidas no arquivo, vedando sejam transcritas e informadas nos certificados ou certidões, ressalvadas as hipóteses legais de atendimento da requisição judicial ou do órgão do Ministério Público e necessidade investigativa. Eliminadas, elas serão destruídas, impossibilitando sua transcrição em certificados ou certidões.

\footnotetext{
490 "Eliminar (lat eliminare) vtd 1 Fazer desaparecer; suprimir: O serviço sanitário trata de eliminar os focos de infecção. vtd $\mathbf{2}$ Excluir: Eliminar candidatos não aptos. vtd $\mathbf{3}$ Fazer sair do organismo: Pelo transpirar eliminamos as toxinas. vtd $\mathbf{4}$ Mat Fazer desaparecer uma incógnita de uma equação em um sistema de várias equações com várias incógnitas. vtd $\mathbf{5}$ Pôr fora da porta; expulsar: Eliminaram-no do clube. vpr $\mathbf{6}$ Matar-se: Ele não tinha motivo para eliminar-se" (itálico original). In: Dicionário Michaelis da língua portuguesa. Disponível $\quad \mathrm{em}: \quad<\mathrm{http} / /$ michaelis.uol.com.br/moderno/portugues/index.php?lingua=portuguesportugues\&palavra=eliminar $>$. Acesso em: 22 set. 2008.

${ }^{491}$ Francisco Bueno Arús (op. cit., p. 131-132) com clareza afirma que "Si la eliminación del antecedente es definitiva, parece obvio que el antecedente eliminado ya no podrá ser tenido en cuenta ni siquiera a los efectos judiciales que dejan subsistentes los artículos 118 del CP de 1973 y 136 del CP de 1995 para los antecedentes solamente cancelados. Pero, en mi opinión, si la palabra eliminación, carente por cierto de una interpretación auténtica, ha de tener algún sentido, tiene que significar la desaparición del Registro de los antecedentes eliminados. Eliminar es, pura e simplemente, borrar" (itálico original).

${ }^{492}$ Id., ibid., p. 94. Na Espanha, também vige a regra - "Jueces y Tribunales, pues, según la ley, ellos conocerán de todas las anotaciones, canceladas o no" - complementada por dispositivo que impõe às referidas autoridades não levar em conta as anotações do registro que poderiam ser canceladas pelo transcurso de prazo, mas ainda não foram.
} 
$\mathrm{Na}$ Espanha, foi apontado ser possível eliminar informações do registro criminal nas seguintes situações, a partir de prescrições encontradas na Real Ordem, de 5 de dezembro de 1892, que não consta estar expressamente revogada:

a) morte comprovada;

b) atingimento de 70 anos de idade desde que a pessoa não cumpra pena ou esteja sendo processada;

c) ocorrência da abolitio criminis;

d) absolvição mediante revisão ou concessão da anistia. ${ }^{493}$

Apesar disso, foi observado nesse país existir resistência de a administração eliminar os registros de antecedentes, mesmo nas situações acima indicadas, sentindo-se tendência em optar pelo cancelamento e não por eliminação das informações. ${ }^{494}$

Também no campo do direito comparado, é interessante referir que em diversos países está consagrada a possibilidade de cancelar ou eliminar as anotações inseridas no registro criminal, fundamentando-se a possibilidade em situações diversas, como a morte, a idade, a revisão das sentenças condenatórias, a descriminalização, o sursis, a liberdade condicional, a reabilitação e as variadas formas do direito de graça, e atribuindo-se denominações variadas ao procedimento gerador do afastamento da anotação. Entretanto, o aspecto mais significativo do cancelamento ou da eliminação dos dados do registro criminal é a prévia verificação dos pressupostos que autorizam não se comunicarem os dados às entidades que, legalmente, teriam acesso às informações do cadastro e, posteriormente, ficarão impedidas de conhecer a informação. Restringir a divulgação pelo cancelamento ou permitir o apagamento dos dados do registro por meio da eliminação são providências que, na prática, estão fundamentadas na economia e no descongestionamento do sistema, mas como também confrontam as idéias da "defesa em face dos ex-condenados ou à sua ressocialização" a adoção dessas medidas dependerá dos objetivos traçados pela política criminal. ${ }^{495}$

Além da exceção referente à possibilidade de acessar dados do registro criminal

\footnotetext{
${ }^{493}$ Francisco Bueno Arús (op. cit., p. 132-133) acrescenta às situações previstas na mencionada Real Ordem outras duas que resultam na eliminação da anotação no registro de antecedentes. São elas as hipóteses de cancelamento da anotação relativa ao cometimento de falta, que parece assemelhar-se às contravenções penais do direito pátrio em virtude de norma penal que possui retroatividade benéfica, além da possibilidade do apagamento em razão da ocorrência da prescrição. O autor ressalta que, apesar de a legislação dar a essas situações efeito de somente cancelar do registro, ambas permitem eliminar a anotação.

${ }^{494}$ GROSSO GALVAN, Manuel, op. cit., p. 153-155.

${ }^{495}$ COSTA, António Manuel de Almeida, op. cit., p. 204-205.
} 
cancelados para fins estatísticos e de investigação científica, acrescentam-se três situações, a seguir descritas e anteriormente mencionadas, em relação às quais é necessário preservar o acesso aos dados cancelados, por entender-se presente justa causa legitimadora do fornecimento das informações integrais do registro, mesmo cancelados. São elas as hipóteses de instrução do pedido judicial para revisão de sentença condenatória, instrução do procedimento relativo a exame médico ou psicológico instaurado para verificar a personalidade ou o estado mental do acusado e atendimento de requerimento feito pelo interessado, ou por terceiro em nome dele, para prova da inocência.

Estabelecer a possibilidade de cancelar determinadas anotações inseridas no registro criminal é demonstração das conseqüências negativas que elas causam, ao mesmo tempo em que isso funciona como uma espécie de benefício para aquele que o alcança. ${ }^{496}$

Neste ponto do estudo justifica-se discutir o cancelamento dos dados do registro criminal, a despeito do entendimento por vezes sustentado em decisões judiciais pelo argumento da proteção do valor histórico do seu conteúdo. ${ }^{497}$

É necessário esclarecer que se defende a idéia de que é possível cancelar as anotações lançadas no registro criminal, impedindo ou restringindo a publicização do seu conteúdo a terceiros e autoridades, apesar dos argumentos contrários a esse pensamento, especialmente a alegação de que é preciso mantê-las, a qualquer custo, para preservar aspectos históricos.

Afirmar-se que a anotação feita no registro criminal deve ser mantida para resguardar o seu valor histórico não pode servir como argumento suficiente para impedir o cancelamento do registro criminal.

A importância histórica está relacionada ao fato em si e não será reduzida pelo cancelamento da anotação do arquivo. O cancelamento é providência que o órgão judiciário responsável pela anotação deve permitir, caso a caso, quando a anotação não se mostrar hábil para demonstrar reincidência ou maus antecedentes e, ainda, prejudicar o conceito social da pessoa ou ampliar o risco de ela sofrer medida restritiva da sua liberdade.

Caso a anotação se refira à pessoa ou a fato que alcançou notoriedade e, portanto, a

${ }_{497}^{496}$ GROSSO GALVAN, Manuel, op. cit., p. 101.

497 "O registro histórico do processo e das informações relativas a ele não pode ser cancelado, apagado ou eliminado dos assentamentos das repartições policiais e do Poder Judiciário, pois é necessário para a preservação da memória histórica da Administração Pública, que exige que seus arquivos sejam completos e fidedignos, a fim de que se saiba tudo que nela tramitou." (BRASIL. Tribunal de Justiça. Mandado de Segurança $\mathrm{n}^{\mathrm{o}} 438.372 .3 / 7 \ldots$, cit.) 
referência possa despertar interesse histórico, não é razoável usar o argumento da existência de valor histórico do registro criminal para impedir seu cancelamento.

A história, como ciência e método de aquisição e transmissão dos conhecimentos, pode valer-se de outras fontes de informação e pesquisa. Os próprios autos do processocrime, as anotações cartorárias e judiciais, os livros de registro policial, ${ }^{498}$ as notas publicadas pela imprensa, o relato das pessoas, ou seja, tudo que servir como fonte de informação pode auxiliar o historiador.

A possibilidade de cancelar determinadas anotações lançadas no registro também é justificada pela constatação de que nesse cadastro há informações que "não cumprem uma missão autêntica e genuína do ponto de vista político-criminal, mas sim, uma vertente meramente estigmatizante". 499

Partindo da premissa que o cidadão não pode ser mero objeto da atividade estatal, pois assim agindo o Estado invadiria o núcleo essencial dos direitos do indivíduo, ${ }^{500}$ é indispensável assegurar ao indivíduo meios para apresentar reações legais ao poder público para fazer inserir anotações no seu registro de antecedentes criminais, facultando-lhe apresentar contra-argumentos à idéia de manter essas anotações no mencionado cadastro.

O cancelamento dos antecedentes anotados no registro deve assumir caráter de autêntico direito desde que cumpridos os requisitos estabelecidos pelo legislador ${ }^{501}$ e sob essa ótica deve ser considerado pelos juízes e tribunais. A estes, em última análise, caberá a tarefa de decidir os pedidos para cancelamento e eliminação dos dados do registro sob a fiscalização do órgão do Ministério Público. Em relação aos registros cancelados, os quais conforme foi afirmado não serão eliminados, também por ordem judicial será deferido o eventual acesso aos dados, se houver justa causa.

Franscisco Bueno Arús afirma que na Espanha a jurisprudência entende que o cancelamento do registro "es un derecho subjetivo del penado y no una gracia, como

\footnotetext{
${ }^{498}$ Os dados inseridos nos livros de registro da polícia e das prisões redigidos entre os anos de 1808 e 1822 e a verificação dos crimes que envolveram libertos (ou forros) e escravos habitantes da cidade do Rio de Janeiro permitiram reconstruir o perfil histórico-social dessa camada da população nesse período e localidade específica. A mencionada pesquisa foi feita a partir da análise desses documentos, mas sem valer-se dos registros individuais de pessoa alguma os quais, inclusive, à época, estavam precariamente sistematizados no Brasil. Essa constatação permite afirmar que não dispor dos registros individualizados de informações criminais de determinada pessoa não impede investigações históricas. (ALGRANTI, Leila Mezan. Os registros da polícia e seu aproveitamento para a história do Rio de Janeiro: escravos e libertos. Revista de História. São Paulo, USP, n. 119 (nova série), p. 115-125, jul. 1985/dez. 1988).

${ }^{499}$ VEIGA, Catarina, op. cit., p. 66.

${ }^{500}$ Id., ibid., p. 37.

${ }^{501}$ GROSSO GALVAN, Manuel, op. cit., p. 300.
} 
afirma también expresamente el segundo párrafo de los artículos 118 del CP de 1973 y 136.1 de CP de 1995 (véanse STS de 15 julio 1984, 14 diciembre 1984 y 27 enero 1987).",502

Oportuno referir disposição, trazida pelo Estatuto da Criança e do Adolescente, ${ }^{503}$ cujo conhecimento é útil no campo da análise do cancelamento do registro criminal.

Nesse texto, consta que a sentença judicial que concede a adoção será inscrita no "registro civil mediante mandado do qual não se fornecerá certidão" e que referido mandado será arquivado e "cancelará o registro original do adotado". Dispõe a legislação que "nenhuma observação sobre a origem do ato poderá constar nas certidões do registro", mas que "a critério da autoridade judiciária, poderá ser fornecida certidão para a salvaguarda de direitos". ${ }^{504}$

Isso permite verificar que na área da infância e juventude existe previsão que cancela o registro de nascimento civil, veda a expedição de certidão que se refira ao ato cancelado e mantém os dados canceladas sob sigilo, afastáveis por ordem da autoridade judiciária, para salvaguarda de direitos.

Essa regulamentação, embora própria do Estatuto da Criança e do Adolescente, ao tratar da adoção, pela semelhança com o cancelamento do registro criminal, deve orientar e servir de parâmetro aos mecanismos que a legislação brasileira poderá fixar para regular o cancelamento do registro criminal.

Apresentadas as formas de afastar a anotação dos dados do registro criminal por intermédio do seu cancelamento e eliminação, destacado não ser o caráter histórico da informação impeditivo absoluto dessas providências, serão analisados outros temas. Depois de discutir a temporariedade do registro, alguns aspectos da reabilitação criminal e o emprego do habeas data, mandado de segurança e habeas corpus utilizados com o fim de alterar o registro, serão analisadas algumas situações específicas que poderão gerar efeito semelhante. Essas situações, ligadas a institutos de natureza penal, processual ou mista, não serão abordadas profundamente, mas tão-somente visualizadas sob o efeito de permitir alterar dados do registro criminal no Brasil.

\footnotetext{
502 Op. cit., p. 26-27.

${ }^{503}$ Lei no 8.069 , de 13 de julho de 1990.

${ }^{504}$ Ver artigo 47 e parágrafos da Lei $n^{\circ} 8.069$, de 13 de julho de 1990.
} 


\subsection{Temporariedade do registro criminal}

O transcurso de tempo é o argumento que deve ser usado para justificar o cancelamento do registro, cabendo admitir, inclusive, que o "transcurso de determinado plazo sin volver a delinquir después de la extinción de la anterior responsabilidad penal es signo de la rehabilitación personal delicuente". ${ }^{505}$

A Constituição Federal brasileira prioriza o princípio da igualdade ${ }^{506}$ e não permite penas de caráter perpétuo, ${ }^{507}$ enquanto o Código Penal, sob a rubrica "limite das penas", fixa que "o tempo de cumprimento das penas privativas de liberdade não pode ser superior a 30 (trinta) anos", determinando regras para unificá-las caso a somatória superar esse limite. $^{508}$

O Código Penal e a legislação penal, em geral, também trabalham com a noção do tempo ao fixar limites mínimo e máximo às penas privativas de liberdade, enquanto o artigo 109 daquele texto legal utiliza, adequadamente, o tempo como critério para regular prazos prescricionais. ${ }^{509}$

Os efeitos do tempo regulados no Código Penal alcançam ainda a reincidência, porque essa circunstância agravante genérica cede ao seu transcurso, tanto que para caracterizá-la "não prevalece a condenação anterior, se entre a data do cumprimento ou extinção da pena e a infração posterior tiver decorrido período de tempo superior a 5 (cinco) anos, computado o período de prova da suspensão ou do livramento condicional, se não ocorrer revogação". 510

${ }^{505}$ BUENO ARÚS, Francisco, op. cit., p. 25.

${ }^{506}$ Francisco Bissoli Filho (op. cit., p. 162) expõe o seguinte pensamento: “A verdade é que os antecedentes, especialmente os negativos, e a reincidência criminal constituem importante fator de diferenciação do criminoso dos demais seres humanos, de tal sorte que o indivíduo que registra alguma espécie de antecedentes negativos ou é reincidente criminal, acaba merecendo, da parte do sistema penal, um tratamento diferencial, sendo considerado, portanto, pertencente a uma categoria específica. Esta diferenciação visa tornar mais nítida a linha que separa os 'bons' dos 'maus', confrontando, assim, com o princípio da igualdade."

${ }_{507}$ Art. 50, inciso XLVII, alínea "b".

${ }^{508}$ Art. 75 do Código Penal. Semelhante regra é encontrada no artigo 10 da Lei das Contravenções Penais, Decreto-Lei $\mathrm{n}^{\mathrm{o}} 3.688$, de 3 de outubro de 1941, que também limita em 5 (cinco) anos o período máximo para o cumprimento da pena de prisão simples.

509 Acerca do tempo em relação à prescrição já foi afirmado que: "O tempo, na esfera penal, tem relevância sobre a conveniência de se manter a persecução criminal sobre o suposto autor de um delito, ou de se executar a sanção aplicada numa decisão condenatória. Vale dizer, com a fixação de prazos o indivíduo não fica sujeito eternamente sob a perseguição do Estado; doutro lado, este se vê forçado a proceder diligências para encerrar o caso que foi colocado a julgamento ou dar cumprimento à sanção decretada." (SHIMURA, Sergio Seiji. Reabilitação - Impossibilidade da prescrição primitiva. Revista de Processo, São Paulo, n. 60, p. 178, out./dez. 1990.

${ }^{510}$ Art. 64, inciso I, do Código Penal. 
Assim, visando impedir a perenidade dos efeitos dos antecedentes e do registro criminal em relação à pessoa que ostenta citadas anotações, referidos institutos deveriam ser interpretados, considerando-se o efeito limitador do tempo sobre a sanção conforme faz a lei penal ao permitir a mencionada "prescrição da reincidência".

Em relação aos antecedentes, inclusive, já foi indicado ser cabível não comunicá-los depois do transcurso de certo lapso temporal contado a partir da data da prática do crime, ${ }^{511}$ embora no Brasil a interpretação literal do Código Penal permita entender que "os efeitos da estigmatização anterior [...] para fins de reincidência perdura durante cinco anos e, para fins de antecedentes, por tempo indeterminado [...] tornando-o refém do passado." 512

Os dados inscritos no registro criminal são pessoais, embora reunidos e mantidos pelo Estado. Ultrapassado lapso temporal suficiente para permitir sejam usados para caracterizar reincidência e maus antecedentes, deveriam ser submetidos ao crivo do “direito ao esquecimento", 513 "que impõe ao responsável pelo tratamento de dados que conserve os dados pessoais apenas durante o período estritamente necessário para a prossecução das finalidades da recolha ou do tratamento posterior". 514

O esquecimento relativo à condenação penal pode ser alcançado por meio da reabilitação, que resulta na declaração do sigilo sobre o processo e a condenação, exceto no caso de requisição judicial.

Regulada a reabilitação criminal pelo Código Penal, o primeiro requisito exigido para sua concessão consiste no cumprimento do prazo de carência de dois anos, contado a partir "do dia em que for extinta, de qualquer modo, a pena ou terminar sua execução, computando-se o período de prova da suspensão e o do livramento condicional, se não sobrevier revogação".

O transcurso do lapso temporal não é a única exigência que deve ser atendida para requerer a reabilitação, porque os três incisos do artigo 94 do Código Penal indicam outras que deverão ser cumpridas. ${ }^{515}$

${ }^{511}$ COSTA, António Manuel de Almeida, op. cit., p. 337 e 342.

${ }^{512}$ BISSOLI FILHO, Francisco, op. cit., p. 216-217.

${ }^{513} \mathrm{O}$ "direito ao esquecimento" foi conceituado como "faculdade de a pessoa não ser molestada por atos ou fatos do passado que não tenham legítimo interesse público. Trata-se do reconhecimento jurídico à proteção da vida pretérita, proibindo-se a revelação do nome, da imagem, e de outros dados referentes à personalidade". [DOTTI, René Ariel. O direito ao esquecimento e a proteção ao habeas data. In: WAMBIER, Teresa Arruda Alvim (Coord.). Habeas data. São Paulo: RT, 1998. p. 300.]

${ }^{514}$ CASTRO, Catarina Sarmento e, op. cit., p. 11.

515 "Art. 94 - A reabilitação poderá ser requerida, decorridos 2 (dois) anos do dia em que for extinta, de 
O pressuposto básico para a reabilitação criminal, portanto, é a existência de sentença penal condenatória transitada em julgado. A reabilitação não é admitida no caso de decisão absolutória, extintiva da punibilidade ${ }^{516}$ ou se ocorreu arquivamento do inquérito policial. ${ }^{517}$

A análise feita mostra que a reabilitação criminal é a providência legal que atenua a publicidade da condenação penal transitada em julgado, gerando sigilo sobre o processo e a condenação, exceto no caso de requisição judicial. Entretanto, o legislador brasileiro não criou mecanismo direto para restringir o acesso aos dados do registro criminal quando a Justiça não pronunciar decisão condenatória, situação que recomenda aplicar-se o princípio da proporcionalidade, permitindo ao interessado buscar providência judicial dotada de efeito pelo menos igual ao gerado pela reabilitação.

Já foi entendido pelo Superior Tribunal de Justiça que o juiz pode proibir a divulgação de processo sem desfecho condenatório cujos dados foram anotados no registro criminal, salvo no caso de requisição judicial, nos termos do artigo 748 do Código de Processo Penal, com base na analogia in bonam partem, conforme admitido. ${ }^{518}$

Nessa decisão, que mencionou faltar sentido em manter os arquivos judiciários escancarados por tempo indeterminado, o então Ministro Luiz Vicente Cernicchiaro disse que o juiz deve notar o "murmúrio das ruas" e "estar atento às conseqüências das leis", afirmando também que "todas as pessoas têm direito à proteção da intimidade, mesmo quem haja sofrido a desventura de ser réu!"

Não atende o princípio da proporcionalidade permitir-se que a divulgação de decisão condenatória seja restringida pela reabilitação criminal, sem facultar-se emprego de qualquer expediente ao acusado absolvido, cuja punibilidade foi extinta, ou à pessoa que sequer foi processada em virtude do arquivamento da investigação. Nestas situações, sem desfecho desfavorável ao indiciado ou suspeito, o registro criminal recebe e conserva,

qualquer modo, a pena ou terminar sua execução, computando-se o período de prova da suspensão e o do livramento condicional, se não sobrevier revogação, desde que o condenado:

I - tenha tido domicílio no País no prazo acima referido;

II - tenha dado, durante esse tempo, demonstração efetiva e consoante de bom comportamento público e privado;

III - tenha ressarcido o dano causado pelo crime ou demonstre a absoluta impossibilidade de o fazer, até o dia do pedido, ou exiba documento que comprove a renúncia da vítima ou novação da dívida.

Parágrafo único. Negada a reabilitação, poderá ser requerida, a qualquer tempo, desde que o pedido seja instruído com novos elementos comprobatórios dos requisitos necessários."

${ }_{516}$ MIRABETE, Julio Fabbrini. Manual de direito penal. 12. ed. São Paulo: Atlas, 1997. v. 1, p. 351 e PRADO, Luiz Regis; BITENCOURT, Cezar Roberto, Código..., cit., p. 405. Cf., também, JESUS, Damásio Evangelista de. Código Penal anotado. 7. ed. São Paulo: Saraiva, 1997. p. 249-250.

517 JESUS, Damásio Evangelista de, op. cit., p. 250.

${ }^{518}$ BRASIL. Superior Tribunal de Justiça. Recurso Ordinário em Mandado de Segurança no 6.761/SP..., cit. 
por tempo indeterminado, anotação sem lastro em decisão condenatória, enquanto naquela, com desfecho desfavorável, transcorrido lapso temporal determinado e cumpridas condições, a reabilitação gera o sigilo do registro criminal.

De modo semelhante, transcorrer certo período de tempo não deveria ser a única exigência prevista para a concessão de pedido judicial para cancelamento do registro criminal que possa ser regulado na legislação nacional, pois a comprovação desse lapso temporal é providência que deveria ser cumulada com outras obrigações, entre elas a comprovação de não estar sendo processado ou não ter sido condenado. ${ }^{519}$

Nesse campo, deve ser evitado condicionar o cancelamento do registro à comprovação da "boa conduta", por tratar-se de "standart jurídico desacreditado pela doutrina", conforme assinalado por Francisco Bueno Arús, diante da imprecisão e fácil manipulação dessa expressão, além do risco de permitir confundir o Direito com a Moral, ao ser apreciada concretamente. ${ }^{520}$

As anotações relacionadas a inquérito policial arquivado ou queixa-crime rejeitada lançadas no registro criminal também deveriam submeter-se ao critério da temporariedade, possibilitando fossem canceladas. Embora o inquérito policial possa ser desarquivado, caso surgirem novas provas, conforme prevê a parte final do artigo 18 do Código de Processo Penal, ${ }^{521}$ ultrapassado determinado lapso temporal, é importante o cancelamento do registro da investigação arquivada em virtude da estigmatização da pessoa investigada.

O prazo mais adequado a se aguardar, antes de cancelar a anotação do registro criminal relativa ao inquérito policial arquivado, parece ser aquele que a lei penal impõe para operar o efeito da prescrição em relação ao crime investigado, considerando-se o patamar inferior da pena prevista pela lei. É controvertido fixar esse prazo com base no mínimo da pena privativa de liberdade cominada ao crime, mas a escolha é guiada pelo

519 A Súmula no 323, do Superior Tribunal de Justiça, editada em 23 de novembro de 2005, dispõe que "a inscrição de inadimplente pode ser mantida nos serviços de proteção ao crédito por, no máximo, cinco anos". Acrescenta-se ao texto o entendimento que para deixar de ter o "nome sujo" o interessado não poderá possuir outras dívidas nesse período. Isso permite considerar que, no campo da defesa do consumidor, a desconsideração da anotação por dívida anterior, além do prazo depurador de cinco anos, também exige inexistência de notícias relativas a outras dívidas não pagas nesse período. Disponível em: $<$ http://busca.folha.uol.com.br/search? $\mathrm{q}=$ cadastro+prote $\% \mathrm{E} 7 \% \mathrm{E} 3 \mathrm{o}+\mathrm{cr} \% \mathrm{E} 9$ dito\&site=online $>$. Acesso em: 24 nov. 2005.

${ }_{520}$ Op. cit., p. 27.

521 “Art. 18 - Depois de ordenado o arquivamento do inquérito pela autoridade judiciária, por falta de base para a denúncia, a autoridade policial poderá proceder a novas pesquisas, se de outras provas tiver notícia. Sobre esse tema, a Súmula 524, do Supremo Tribunal Federal dispõe que: 'Arquivado o inquérito policial, por despacho do juiz, a requerimento do Promotor de Justiça, não pode a ação penal ser iniciada, sem novas provas"” (Disponível em: http://www.stf.jus.br/portal/cms/verTexto.asp?servico=jurisprudenciaSumula\&pagina =sumula_501_600. Acesso em: $11 \mathrm{dez}$.2008). 
princípio da proporcionalidade em sentido estrito e pela possibilidade de reduzir a estigmatização da pessoa humana.

Invoca-se o requisito intrínseco do princípio da proporcionalidade como um dos fundamentos para justificar a posição adotada. A pessoa não processada nem condenada, somente investigada a partir de inquérito policial arquivado, permaneceria impossibilitada de requerer providências para cancelar a respectiva anotação do registro criminal por prazo superior àquele que deveria aguardar caso condenado a cumprir pena fixada no mínimo legal previsto para o crime cometido, se usado como referência o máximo da pena privativa de liberdade. Ao condenado é assegurado requerer a reabilitação criminal contados dois anos do dia em que a pena foi extinta, de qualquer modo, ou terminar sua execução, computando-se o período de prova da suspensão e do livramento condicional, se não sobrevier revogação, conforme dispõe o artigo 94, caput, do Código Penal, enquanto a pessoa investigada por meio de inquérito policial arquivado estaria obrigada aguardar prazo superior, portanto, desproporcional. ${ }^{522}$

Ao tratar do transcurso do "prazo de prova" como um dos requisitos para o deferimento do cancelamento do registro criminal na Espanha, Francisco Bueno Arús entende cabível "dispensar el transcurso del plazo de prueba previo a la cancelación” se "el interesado demuestre que se ha rehabilitado socialmente para que el Estado lo rehabilite jurídicamente". Pouco depois, transcreve escrito de Pedro Romero Macías, Jefe del Registro Central de Penados y Rebeldes del Ministerio de Justicia, afirmando que "potenciar la actividad laboral es la mejor defensa social contra el delito.,"523

Referidas afirmações permitem considerar, inclusive, que em determinadas situações aguardar-se o prazo mínimo para cancelar as anotações do registro criminal é critério que poderá ser amenizado se os fatores subjetivos favorecerem o requerente.

\footnotetext{
522 Significativo confrontar a situação da pessoa condenada por homicídio simples (artigo 121, caput, do Código Penal) ao cumprimento de pena mínima de seis anos de reclusão à situação da pessoa investigada pelo mesmo crime, na qual o inquérito policial que apurou o fato foi arquivado. $\mathrm{O}$ condenado, cumpridos seis anos de reclusão, poderia atender o requisito temporal para requerer a reabilitação criminal depois de dois anos contados do término da pena, sem falar no aproveitamento de eventual período de livramento condicional. O investigado deveria aguardar vinte anos, a contar do arquivamento do inquérito policial, para requerer o cancelamento do registro criminal respectivo, levando-se em conta a pena máxima imposta ao crime investigado e o critério temporal do artigo 109 do Código Penal. Alterado o exemplo criado para a hipótese de alguém também condenado a cumprir por homicídio simples pena de doze anos de reclusão, dobro do mínimo, seria cabível sua reabilitação antes de permitir-se ao investigado pela prática de idêntico crime com investigação arquivada requerer o cancelamento do registro criminal. O condenado estaria apto a requerer a reabilitação depois de dois anos de cumprir a condenação de doze anos, prazo ainda menor que o lapso de vinte anos previsto em relação ao investigado que sequer foi processado.

${ }_{523}$ Op. cit., p. 96-97.
} 
O registro da investigação estigmatiza, no meio social, a pessoa indiciada em inquérito policial ou, de qualquer modo, considerada suspeita da autoria de crime que a polícia investiga. A intensidade dessa exposição e os efeitos que podem causar à privacidade do investigado são aumentados pelos meios de comunicação. ${ }^{524}$

O rigor dos efeitos gerados pela anotação inserida no registro criminal sem correspondente sentença penal condenatória transitada em julgado permite associá-la a outra, extraída da literatura, com a finalidade de enfatizar os reflexos do registro da investigação em relação ao investigado.

O capítulo XXVIII da segunda parte da obra Dom Quixote apresenta a narrativa de uma das várias aventuras do Cavaleiro de Triste Figura e seu escudeiro Sancho Pança cujas peripécias, descritas pelo autor no capítulo anterior, resultaram em violenta surra sofrida somente por Sancho, aplicada por membros de um estranho esquadrão de "zurradores". Essa sova ocorreu quando o escudeiro foi abandonado pelo amo que bateu em retirada ao perceber que também poderia ser trucidado pelo grupo. Depois de receber numerosos golpes com pedaços de pau, Sancho retomou seu caminho e encontrou-se com seu amo Dom Quixote. Este examina o corpo daquele em busca de feridas, mas se surpreende por encontrá-lo são, sem machucaduras visíveis. Logo depois, recolocados sobre suas montarias, a dupla retomou a peregrinação. No percurso, de quando em quando, Sancho emitiu profundos e dolorosos gemidos, queixando-se das dores sentidas do "extremo do espinhaço até a nuca". ${ }^{525}$

Essa situação pitoresca, produto da magnífica obra literária produzida por Cervantes, assemelha-se àquela vivenciada pela pessoa que, sem ostentar condenação criminal, foi submetida à investigação policial, mas as anotações relativas ao inquérito permanecem no seu registro sem permitir apagamento, porque sem exibir "machucaduras visíveis", que poderiam ser comparadas à condenação, sofre "dores indescritíveis", resultado da investigação que respondeu.

Finalizando, cabe admitir que o juiz ou tribunal que determinou a inserção dos dados no registro criminal deve apreciar e deferir requerimento do interessado para cancelar essa anotação, ultrapassado determinado lapso temporal e cumpridas outras

\footnotetext{
${ }^{524}$ Ao tratar do sigilo das investigações criminais e a mídia, Ana Lúcia Menezes Vieira (Processo penal e mídia. São Paulo: RT, 2003. p. 204) afirma que: “Outro aspecto é a estigmatização do indiciado. A só notícia de fato criminoso é sempre deletéria. Muito mais o será quando a imprensa noticia o nome, adjetiva negativamente a pessoa que está sendo investigada. Sua vida familiar, social e trabalho é prejudicada, sua honra, imagem e privacidade são destruídas."

525 SAAVEDRA, Miguel de Cervantes. Dom Quixote de La Mancha. Tradução de Viscondes de Castilho e Azevedo. São Paulo: Nova Cultural, 2002. p. 476-477.
} 
exigências que a legislação poderia fixar. Essa providência seria dotar o sistema de uma espécie de "porta de saída", ${ }^{526}$ importante meio para fazer o registro criminal respeitar e preservar a privacidade da pessoa, valor protegido pela Constituição Federal brasileira.

\subsection{A reabilitação e o registro criminal}

No aspecto histórico, a reabilitação era o inverso da infâmia, porque tratava de constatar se o condenado passou a gozar de impecável reputação pública. A medida era concedida em cerimônia pública realizada depois do exame dos seus pressupostos, em especial, da boa conduta. As raízes da reabilitação são encontradas na Idade Média, mas é somente a partir da Revolução Francesa que é possível notar sua desvinculação dos institutos que a precederam, como o perdão e a graça. O primeiro passo para a regulação da reabilitação ocorreu na França, a partir de uma ordenança real, de 1670, que exigiu para sua concessão o cumprimento da pena e, sempre que possível, a reparação do dano. O segundo é encontrado no Código Penal francês, de 1791, enquanto o terceiro se situa também na França, a partir do Código de Instrução Criminal, de 1808, que estabeleceu tivesse a reabilitação caráter público, anotando-se em boletim judicial o lugar que a concedeu e daquele onde foi decretada a condenação. ${ }^{527}$

Existe interesse em analisar a reabilitação neste estudo, porque durante sua evolução é possível notar que a alteração das condições sociais e a adoção enfática das orientações preventivo-especiais pela doutrina e legislação de diversos países europeus permitiram fosse ela empregada para alterar o registro criminal. O foco da reabilitação migrou, portanto, da busca de efeitos contra a estigmatização causada pela condenação para a eliminação dos registros ou, ao menos, a inviabilização da comunicação do conteúdo dos cadastros às entidades que pudessem conhecê-lo.

Retomando alguns aspectos da sua evolução a partir do século XIX, na França, país considerado o local do nascimento da reabilitação, outras características e avanços foram incorporados ao instituto, numa espécie de primeira fase da reabilitação, com as seguintes características gerais:

a) permitiu a legislação de 1832 que a reabilitação alcançasse penas de caráter

\footnotetext{
${ }^{526}$ José Laércio Araújo (op. cit., p. 117), ao tratar dos arquivos policiais e criminais, afirma que: “O problema assume proporções maiores ao se verificar que o complexo de informações só mantém o registro de suas entradas, dificilmente corrigindo-as posteriormente ou lançando-as fora."

${ }^{527}$ COSTA, António Manuel de Almeida, op. cit., p. 211-212.
} 
aflitivo e infamante, enquanto, em 1835, outra lei estendeu seu alcance àquelas de caráter correicional;

b) transferiu-se o poder de apreciar o pedido em última instância do Presidente da República ao Ministro da Justiça;

c) ganhou, a partir de 1885, a reabilitação caráter de direito do condenado que cumpriu pena, rompendo semelhança que por muito tempo guardou com a graça;

d) previu-se, dessa época em diante, também, que a reabilitação apagava a condenação, efeito que até hoje muitas legislações não conseguiram estabelecer de modo razoável;

e) alterou-se, no mesmo período, a postura de negar a reabilitação aos reincidentes para concedê-la a partir do transcurso de lapso temporal superior (em dobro) ao exigido dos não reincidentes. ${ }^{528}$

A fase seguinte do desenvolvimento da reabilitação é visualizada a partir de outra lei, de 1899, que regulava o registro criminal francês e a reabilitação. Referida legislação firmou a natureza da reabilitação como direito do condenado e permitiu a expedição de circulares administrativas para autorizar o exercício desse direito, inclusive fixando que a reabilitação deveria ser concedida automaticamente, desde que satisfeito determinado lapso temporal e comprovado bom comportamento, resultando na perda da validade da anotação do "casier judiciarie".

Em linhas gerais, a legislação de diversos países exige a comprovação do requisito da boa conduta para conceder a reabilitação, entendido de forma majoritária, como a ausência de novas condenações. ${ }^{529}$

Esses textos legislativos ganhariam objetividade caso estabelecessem como requisito para concessão da reabilitação "não ter cometido crime no prazo da reabilitação", embora seja fácil visualizar que exigir boa conduta para conceder a reabilitação confere maior poder à autoridade responsável pela sua concessão. ${ }^{530}$

Na prática, a reabilitação corresponde ao mero cancelamento do registro criminal e fundamenta-se em postulados e exigências calcados no princípio da prevenção especial. ${ }^{531}$

A análise do funcionamento da reabilitação, em diversos países nos quais ela é

\footnotetext{
${ }^{528}$ GROSSO GALVAN, Manuel, op. cit., p. 231-236.

${ }^{529}$ COSTA, António Manuel de Almeida, op. cit., p. 216.

${ }^{530}$ GROSSO GALVAN, Manuel, op. cit., p. 278-279.

${ }^{531}$ COSTA, António Manuel de Almeida, op. cit., p. 217.
} 
prevista, permite notar ser possível dividi-la em duas grandes espécies, a saber, a reabilitação legal e a reabilitação administrativa ou judicial. A primeira é concedida ao condenado que tenha permanecido sem envolver-se com crimes durante determinado tempo, ou pelo menos, sem envolver-se com crimes graves. A segunda exige prévia constatação da reintegração social do condenado.

A legislação belga consagrou o effacement ou "reabilitação especial" por meio do qual é permitido o cancelamento do registro criminal pelo mero transcurso de lapso temporal determinado, independentemente da execução efetiva da pena e do cometimento de novos crimes. Esse instituto permite o cancelamento automático do registro criminal relativo às infrações muito leves, não-geradoras de incapacidades ou interdições por mais de 5 (cinco) anos, sem comprovação da execução ou extinção da pena. O prazo para sua aplicação conta da data da condenação e aplica-se a tantas quantas forem as condenações existentes. $^{532}$

Na legislação européia, de modo amplo, a reabilitação assumiu a natureza de “direito do condenado ressocializado", passível de ser reclamado perante o órgão judicial competente. Há legislações em que a prática excepcional de atos meritórios, com risco da própria vida para atendimento de interesse social, permitem a concessão da reabilitação sem necessidade de atendimentos de quaisquer requisitos. ${ }^{533}$

Se o condenado foi reabilitado, não há justificativa para fins de defesa social que legitime a inserção da informação relativa à condenação nas certidões extraídas do registro criminal para atender a solicitação das entidades públicas e privadas. O prazo exigido para a concessão da reabilitação é suficientemente longo e abrange espaço de tempo em que, por tendência, oitenta por cento das novas condenações podem acontecer. Os vinte por cento restantes encontram-se dentro do índice do "risco que a coletividade tem de correr, como tributo da sua participação na ressocialização dos delinqüentes". 534

$\mathrm{Na}$ Espanha, a reabilitação concedida com base no antigo texto do artigo 118 do Código Penal, que tornava sem efeito o cancelamento outorgado e restabelecia a eficácia da inscrição cancelada quando o reabilitado cometesse novo delito posteriormente à concessão da reabilitação, foi considerada como "uma brilhante exposição de princípios, mas vazia de conteúdo" e "excessivamente limitada". 535

${ }^{532}$ COSTA, António Manuel de Almeida, p. 217-219. Ver, especialmente, nota de rodapé 393.

${ }_{333}$ MANZINI, Vicenzo. Trattato di diritto penale italiano. 4. ed. Torino: Torinese, 1961. v. 3, p. 717.

${ }^{534}$ COSTA, António Manuel de Almeida, p. 308-310.

${ }^{535}$ GROSSO GALVAN, Manuel, op. cit., p. 41 e 44. 
A partir dessa retrospectiva histórica da reabilitação, é possível entender que o instituto adquiriu natureza jurídica de "verdadeiro direito subjetivo que possui o condenado uma vez cumprida as condições para sua concessão". 536

A reabilitação deixou de ocupar o lugar de ato de clemência para alcançar status de direito do condenado que atendesse os requisitos legais para pleiteá-la e estivesse, ${ }^{537}$ presumidamente, ressocializado, tanto que se considerou de natureza declaratória o ato da sua concessão. ${ }^{538}$

\subsection{Outros aspectos da reabilitação e do registro criminal}

No Brasil, o artigo 95 do Código Penal dispõe que a reabilitação será revogada de ofício ou a requerimento do Ministério Público, se a pessoa for condenada como reincidente, por decisão definitiva, à sanção que não seja de multa. Assim, é necessário que, entre a data do cumprimento ou extinção da pena e a segunda infração, não tenha transcorrido o período de 5 (cinco) anos, depurador da reincidência, e que a pena aplicada seja privativa de liberdade ou restritiva de direitos.

O regramento nacional da reabilitação deixa claro, portanto, que o seu deferimento não cancela ou elimina os antecedentes, mas tão-somente confere sigilo dos registros sobre o processo e a condenação, conforme previsão da parte final do caput do artigo 93 do Código Penal. Como juízes e membros do Ministério Público mantêm acesso aos antecedentes criminais relacionados a processo no qual foi deferida reabilitação, no caso da sua revogação por motivo de condenação definitiva como reincidente ao cumprimento de pena que não seja de multa, resta a possibilidade de rediscutir se a condenação reabilitada e revogada gerará reincidência ou maus antecedentes.

Fixar ou não a reincidência como causa de revogação da reabilitação e, conseqüentemente, restabelecer o registro do antecedente que foi cancelado pela concessão da reabilitação é questão de política criminal orientada no modo pelo qual é apreciado o

\footnotetext{
${ }^{536}$ GROSSO GALVAN, Manuel, op. cit., p. 245.

${ }^{537}$ Francisco Bueno Arús (op. cit., p. 111-112), depois de cuidar do procedimento para o cancelamento dos antecedentes penais na Espanha, que corresponde à reabilitação tratada pelo Direito Penal brasileiro, aponta que há três meios para alcançar o mencionado cancelamento (a pedido do interessado, de ofício pelo Ministério da Justiça e de ofício pelos juízes e Tribunais). Em seguida, o autor esclarece que se referir ao cancelamento dos antecedentes penais com a expressão "benefício" não lhe retira a condição jurídica de direito subjetivo, que verdadeiramente ostenta.

${ }^{538}$ COSTA, António Manuel de Almeida, op. cit., p. 214.
} 
instituto da reabilitação e os seus reflexos no campo do registro criminal.

Dividindo essas duas posturas, estão as opiniões daqueles para quem a reincidência tem tamanho reflexo que anula a reabilitação concedida em frente do pensamento de outras pessoas que entendem que o cometimento de outro crime não pode fazer ressurgir antecedentes criminais que foram cancelados pela concessão da reabilitação. ${ }^{539}$

Entre as duas posições citadas parece mais equilibrado e garantista seguir uma postura intermediária, segundo a qual deveria ser exigido transcurso de determinado período temporal depois da concessão da reabilitação para cancelar a anotação do registro impedindo-se, a partir de então, seu restabelecimento no caso de aquele agente ser condenado em novo processo criminal.

Neste trecho do estudo é necessário observar que a legislação penal nacional não avançou em relação às conseqüências da reabilitação, especialmente não impôs a eliminação nem o cancelamento do registro resultante da condenação criminal, somente sua não-publicidade ao assegurar "ao condenado o sigilo dos registros sobre seu processo e condenação", tanto que já foi considerado como "dispositivo de reduzidíssima valia prática e menor importância". 540

Aliás, a emissão de informações relativas aos antecedentes criminais sem anotações é efeito concedido pelo dispositivo inserido no artigo 202 da Lei de Execução Penal sem qualquer outra exigência que não o cumprimento ou extinção da pena. ${ }^{541}$

A diferença entre eliminação e cancelamento do antecedente criminal anotado no registro como resultado da concessão da reabilitação é significativa, porque, cancelado o antecedente, poderá "reviver", enquanto a eliminação impedirá sua "ressureição". A opção pelo não-apagamento do antecedente criminal do reabilitado amplia o efeito repressivo da pena e dá aos antecedentes a característica, ainda que imprópria, de uma espécie de sanção perpétua. Normalmente, o fundamento da opção pela eliminação ou cancelamento dos antecedentes tem íntima ligação com o entendimento que é firmado a partir do instituto da reabilitação, pois para os estudiosos e os sistemas que consideram a reabilitação como direito é adequado aceitar como reflexo a eliminação dos antecedentes, enquanto se a reabilitação é considerada como concessão estatal, o efeito desse entendimento é do mero cancelamento da anotação, quando não, como o singelo sigilo dos registros conforme

\footnotetext{
${ }^{539}$ GROSSO GALVAN, Manuel, op. cit., p. 313.

${ }^{540}$ DELMANTO, Celso. Código Penal comentado. 3. ed. Rio de Janeiro: Renovar, 1991. p. 144.

541 PRADO, Luiz Regis; BITENCOURT, Cezar Roberto, Código..., cit., p. 405. Cf., também, JESUS, Damásio Evangelista de, op. cit., p. 249-250.
} 
preconiza o caput do artigo 92 do Código Penal brasileiro. A eliminação do antecedente criminal reabilitado é meta a ser perseguida pelo instituto da reabilitação. ${ }^{542}$

Os principais motivos para não eliminar antecedentes alcançados pela reabilitação são a necessidade de exercer maior controle dos reincidentes e realizar a correta individualização da pena. Essas razões se contrapõem, na prática, à meta da redução da influência dos antecedentes penais para facilitar a real reabilitação dos condenados, ${ }^{543}$ exigindo que, a partir das razões alegadas e da busca da meta referida, seja encontrado um ponto ideal para que qualquer delas não inviabilize a outra.

A reabilitação alcança as pessoas vivas, mas em tempos passados também poderia ser deferida em favor dos mortos, pois se tratando do reverso da infâmia, que atingia a memória da pessoa falecida, a reputação e a condição jurídica dos seus descendentes poderiam ser resgatadas em razão da reabilitação do defunto. Entretanto, como a morte deveria refletir no registro criminal, a reabilitação do morto perde o sentido, embora no Brasil esse reflexo ainda não está legalmente regulado.

Referir, com base no direito comparado, os efeitos que a reabilitação gera ao registro criminal, ou seja, se ela implica no seu cancelamento em relação a todos órgãos e pessoas que tenham acesso à informação ou somente parte deles, é conveniente para orientar posturas que podem ser adotadas no Brasil. A respeito disso, frisa-se que a quase totalidade das legislações européias dispõe que a reabilitação permite excluir das certidões expedidas todas as informações fornecidas aos particulares, enquanto a maior parte dos textos legais indica que, embora concedida a reabilitação, a informação deverá ser fornecida aos órgãos administrativos encarregados da apuração criminal e investigação policial. $^{544}$

A reabilitação, direito concedido ao condenado que se readaptou ao convívio social, não pode ser circunscrita a determinados crimes e classes de criminosos. Ela deve ser concedida, independentemente do tipo penal violado e da personalidade do criminoso, embora não seja desproporcional exigir maior rigor para o seu deferimento.

Assim, estimula-se "a idéia da ressocialização dos delinqüentes, consubstanciada, não só na crença na sua corrigibilidade e no estabelecimento de índices 'cientificamente' fundados para comprovação dela, mas também na eliminação de todos os elementos que,

\footnotetext{
${ }^{542}$ GROSSO GALVAN, Manuel, op. cit., p. 252-254.

${ }^{543}$ Id., ibid., p. 256-257.

${ }^{544}$ COSTA, António Manuel de Almeida, op. cit., p. 224-225.
} 
não sendo indispensáveis à defesa da sociedade, constituem obstáculo à reintegração dos condenados". 545

Em linhas gerais, a idéia que paira ao lado da reabilitação não está ligada, exclusivamente, ao condenado retornar à situação anterior ao momento da condenação, tanto que o Brasil e grande parte dos países nos quais os ordenamentos jurídicos dispõem acerca da reabilitação existe vedação expressa de reintegração a cargo ou função pública ou mandato eletivo ao condenado reabilitado. A virtude maior buscada pela reabilitação e a garantia que ela deve gerar é que os fatos delitivos motivadores da condenação não mais repercutirão a partir da sua concessão. ${ }^{546}$

O principal efeito da reabilitação é cancelar os antecedentes criminais, mas isso pode ser obtido de modo mais ou menos amplo, conforme o sistema adotado que poderá inclinar-se por permitir o cancelamento imediato, o cancelamento progressivo ou somente a restrição da publicidade dos antecedentes. O primeiro deles se caracteriza pelo cancelamento automático dos antecedentes criminais a partir da concessão da reabilitação, enquanto o segundo propõe divisão temporal do efeito cancelatório em dois tempos, pois no primeiro os antecedentes ficam cancelados e depois do transcurso de determinado prazo são efetivamente eliminados, retornando o agente à condição de alguém que nunca cometeu crime. $\mathrm{O}$ último sistema é aquele que torna secreto o registro aos particulares a partir da concessão da reabilitação, sem dirigir esse efeito aos órgãos judiciais e administrativos, sendo característico dos ordenamentos jurídicos em que o poder executivo é muito forte. ${ }^{547}$

O caráter da concessão da reabilitação é variado, mas para atender a idéia da reintegração social do condenado, o sistema legal deve privilegiar que a sua concessão seja irrevogável pelo menos depois de determinado período de tempo. Quando se refere ao seu caráter, se quer dizer da possibilidade da sua revogação e das condições necessárias para que isso ocorra. Nesse aspecto, a reabilitação terá que assumir três modalidades, a saber: provisória, definitiva e mista. A primeira delas admite a revogação, situação não permitida para a segunda, enquanto a terceira autoriza a revogação até determinada época que,

\footnotetext{
${ }^{545}$ COSTA, António Manuel de Almeida, op. cit., p. 226.

${ }^{546}$ GROSSO GALVAN, Manuel, op. cit., p. 312. O autor menciona em seu estudo, aliás, que Bulgária e Hungria eram exceções, pois em meados de 1980 a reabilitação concedida nesses países anulava todos os efeitos da condenação e permitia recolocar o condenado no cargo ocupado antes do cometimento do crime. Referida postura parece exceder a finalidade prevista para a reabilitação e reflete no campo administrativo pela natural dificuldade que deve ser gerada com a recondução do servidor ao exercício da função da qual foi afastado pela prática de crime.

${ }^{547}$ Id., ibid., p. 307-308.
} 
ultrapassada, veda a alteração da reabilitação. ${ }^{548}$

Ligada ao caráter da reabilitação está a questão da permanência ou da exclusão das informações referentes a condenações reabilitadas no registro criminal, ou seja, seu cancelamento ou eliminação, tema antes analisado. As legislações estrangeiras dispõem de um modo ou de outro, conforme resultem de maior força as idéias de defesa social ou da ressocialização do criminoso, embora não seja somente a inclinação político-criminal que interfira na opção, mas ainda razões diversas, como a necessidade de manter os levantamentos científicos e a estatística criminal. ${ }^{549}$

A reparação dos danos é providência cuja satisfação deverá ser exigida dentro das possibilidades daquele que pretende alcançar a reabilitação, observada a realidade sócioeconômica da maior parte dos condenados e o freqüente envolvimento com crimes patrimoniais, sérios indicativos da impossibilidade de ressarcir os danos. A comprovação do cumprimento dessa obrigação, embora tenha feição de "declaração de boas intenções por parte do legislador", demonstra preferência positiva de valor assumida pela legislação. ${ }^{550}$ Deve ser preservada a exigência da reparação dos danos nos textos legais reguladores da reabilitação e estimulada a avaliação criteriosa dessa exigência nos julgamentos que precedem sua concessão pelos juízes e tribunais.

A reabilitação guarda relação próxima ao registro e aos antecedentes criminais, porque sua concessão influirá nos dados criminais arquivados e, por conseqüência, refletirá nos antecedentes penais de determinada pessoa. Aliás, dentre eles, a reabilitação surge como o tema que mais atrai a atenção da doutrina. A reabilitação trata, praticamente, do único meio jurídico empregado para suavizar os efeitos negativos dos antecedentes penais. Ela se assenta em uma espécie de renúncia estatal em manter controle sobre aquele que cumpriu pena e visa eliminar as conseqüências dessa pena cumprida ou extinta, imposta a partir da fixação da responsabilidade penal do agente. Esse instituto, que teria a finalidade de reconduzir o condenado ao gozo de situação jurídica e social anterior ao momento da prática do crime, ostenta como requisitos essenciais o bom comportamento social e o transcurso de lapso temporal os quais não deveriam ser exigidos "já que o cumprimento da condenação deveria bastar para que seus efeitos desaparecessem". 551

No campo administrativo, nota-se que também vige a idéia de impedir o emprego

\footnotetext{
${ }^{548}$ COSTA, António Manuel de Almeida, op. cit., p. 228.

${ }^{549}$ Id., ibid., p. 229, ver notas de rodapé 416, 417 e 418.

${ }^{550}$ GROSSO GALVAN, Manuel, op. cit., p. 285.

${ }^{551}$ Id., ibid., p. 222-228.
} 
de anotação disciplinar desabonadora depois de transcorrer lapso temporal determinado e inexistir prova da prática de outra infração. Exemplo disso é encontrado na Lei Orgânica do Ministério Público do Estado de São Paulo, Lei Complementar n ${ }^{0}$ 734, de 26 de novembro de $1993,{ }^{552}$ que concede uma espécie de reabilitação automática da imposição de sanção disciplinar desde que passados 5 (cinco) anos da condenação anterior sem cometimento de outra infração.

É necessário que a reabilitação gere maior efeito no registro criminal do que assegurar sigilo das anotações relativas ao processo e à condenação conforme previsto pela legislação nacional.

O registro criminal reúne informações produzidas, normalmente, a partir das investigações e dos processos criminais, os quais, em regra, não são sigilosos. Ocorre que o agrupamento individualizado desses dados forma um rico arquivo de dados pessoais ${ }^{553}$ relacionado a diversos aspectos da vida privada das pessoas que é gerenciado pelo Poder Público. Isso permite concluir que a informação extraída do registro criminal deve ter a natureza de informação reservada, independentemente do sigilo atribuído como efeito da reabilitação.

A reabilitação produziria efeitos sensíveis caso permitisse o cancelamento da respectiva condenação, somente divulgada mediante expressa autorização judicial. A reabilitação poderia evoluir ainda mais caso se estruturasse no Brasil de modo que o instituto permitisse, além do cancelamento, a eliminação das anotações inseridas no registro criminal, mediante requerimento do interessado, desde que transcorrido

552 “Art. 247 - As decisões referentes à imposição de pena disciplinar constarão do prontuário do infrator com menção dos fatos que lhe deram causa. Parágrafo único - Decorridos 5 (cinco) anos da imposição da sanção disciplinar, sem cometimento de nova infração, não mais poderá ela ser considerada em prejuízo do infrator, inclusive para efeito de reincidência. No mesmo sentido e com redação idêntica, encontra-se o artigo 221 e seu parágrafo único da Lei Complementar $n^{\circ} 11$, de 18 de janeiro de 1996, que institui a Lei Orgânica do Ministério Público do Estado da Bahia" (LEI ORGÂNICA DO MINISTÉRIO PÚBLICO DO ESTADO DE SÃO PAULO, Lei Complementar no 734, de 26 de novembro de 1993. Publicações Eletrônicas Associação Paulista do Ministério Público. São Paulo: APMP, 2004-2006. 1 CD-ROM. Produzido por Eduardo Roberto Alcântara Del-Campo e Marinilce Araújo Soria).

${ }^{553} \mathrm{O}$ arquivo de dados pessoais é resultado distante da invenção da escrita, pois ela nasceu para suprir a necessidade humana de comunicação e ao mesmo tempo para permitir a conservação e transmissão de informações. Os arquivos de dados pessoais existem desde a antiguidade e são conhecidos há muito tempo, tais como os registros paroquiais, tributários, civis, escolares, policiais, comerciais, de propriedade, clínicos, podendo ser citado, a título de exemplo, o arquivo dos registros de nascimento criados na Roma de Augusto por intermédio da legislação “Aelia Sentia y Papia Poppaea”. Entretanto, são as novas tecnologias de informação e comunicação que agilizaram as tarefas de obter, armazenar, processar e transmitir dados, aumentando, a cada dia, o relacionamento entre os dados colhidos e a criação de novas informações. Isso exige encontrar adequado equilíbrio entre os direitos constitucionais, protegendo a intimidade para evitar discriminação e a liberdade de informação e publicidade dos atos do governo, essenciais ao sistema democrático (SLAVIN, Diana de. Mercosur: la protección de los datos personales. Buenos Aires: Depalma, 1999. p. 92-93). 
determinado lapso temporal e comprovado inexistir envolvimento do requerente com a prática de crimes nesse espaço de tempo.

\subsection{Habeas data e registro criminal}

É necessário conhecer certas peculiaridades do habeas data, do mandado de segurança e do habeas corpus, pois essas ações de natureza constitucional, conhecidas como remédios constitucionais, ${ }^{554}$ poderão ser empregadas por quem desejar ter acesso aos dados pessoais armazenados no registro criminal ou pretender alterá-los.

O habeas data, previsto no Brasil pela Constituição Federal, de $1988,{ }^{555}$ foi tratado pela Lei $\mathrm{n}^{\circ}$ 9.507, de 12 de novembro de 1997, que regula o direito constitucional de acesso às informações e disciplina o rito processual desse remédio constitucional. ${ }^{556}$ Ele pode ser empregado pelo impetrante que desejar conhecer, retificar ou inserir informações em registro ou banco de dados de entidades governamentais e de caráter público.

Antes da entrada em vigor da Constituição Federal, de 1988, a importância do conhecimento, do acesso e da retificação das informações reunidas em banco oficial de dados havia sido tratada pelo legislador estadual paulista por meio da Lei $\mathrm{n}^{\circ} 5.446$, de 19 de dezembro de 1986, que dispôs "sobre o acesso do cidadão às informações sobre a sua

${ }^{554}$ José Afonso Silva (op. cit., p. 386) considera remédios constitucionais "os meios postos à disposição dos indivíduos e cidadãos para provocar a intervenção das autoridades competentes, visando sanar, corrigir, ilegalidade e abuso de poder em prejuízo de direitos e interesses individuais."

555 “Art. $5^{\circ}$ - Todos são iguais perante a lei, sem distinção de qualquer natureza, garantindo-se aos brasileiros e aos estrangeiros residentes no País a inviolabilidade do direito à vida, à liberdade, à igualdade, à segurança e à propriedade, nos termos seguintes:

LXXII - conceder-se-á habeas data:

a) para assegurar o conhecimento de informações relativas à pessoa do impetrante, constantes de registros ou bancos de dados de entidades governamentais ou de caráter público;

b) para a retificação de dados, quando não se prefira fazê-lo por processo sigiloso, judicial ou administrativo; $[\ldots]$

LXXVII - são gratuitas as ações de habeas corpus e habeas data, e, na forma da lei, os atos necessários ao exercício da cidadania."

${ }^{556}$ Foi frisado, acertadamente, que o dispositivo constitucional inserido no artigo $5^{\circ}$, inciso LXXII, da Constituição Federal, que trata do habeas data, deve ser lido à luz dos seguintes mandamentos também presentes no mesmo texto constitucional: a) artigo $5^{\circ}$, inciso $\mathrm{X}$ - proteção da intimidade, da vida privada, da honra e da imagem da pessoa; b) artigo $5^{\circ}$, inciso XII - inviolabilidade das comunicações de dados; c) artigo $5^{\circ}$, inciso XXXIII - direito de receber de órgãos públicos informações de interesse particular ou interesse coletivo ou geral, ressalvadas aquelas cujo sigilo seja imprescindível à segurança da sociedade e do Estado; d) artigo $5^{\circ}$, inciso XXXIV - direito de petição aos Poderes Públicos em defesa de direito ou contra ilegalidade ou abuso de poder e direito de obter certidão em repartições públicas para defesa de direitos e esclarecimento de situações de interesse pessoal, ambos exercidos, independentemente, do pagamento de taxas; e) artigo 37 - princípio da publicidade, entre os demais que informam a atividade administrativa [CLÉVE, Clémerson Merlin. Habeas data: algumas notas de leitura. In: WAMBIER, Teresa Arruda Alvim (Coord.). Habeas data. São Paulo: RT, 1998. p. 74]. 
pessoa". 557

Referida lei, redigida em quatro artigos e sancionada pelo Poder Executivo com vetos parciais, reconheceu ao cidadão direito de acesso às informações sobre a sua pessoa armazenadas em bancos de dados ou arquivos do Estado, da Administração Direta e Indireta e também lhe permitiu conhecer a destinação desses informes. A legislação paulista facultou ao cidadão consultar e exigir a retificação dos seus dados pessoais em caso de falha ou inexatidão e dispôs que o requerimento de retificação devia ser encaminhado diretamente à administração do banco de dados ou arquivo. Encerrou o texto legal artigo que restringia o emprego das informações constantes dos bancos de dados ou arquivos para fins diversos daqueles para os quais foram obtidas.

A existência dessa legislação estadual foi mencionada, incidentalmente, por Fernando da Costa Tourinho Filho, ao tratar da competência dos juízes federais para apreciar habeas data ajuizado contra ato de autoridade federal. ${ }^{558}$ Nesse trecho da obra, o autor ressalta a atuação de José Afonso da Silva para fazer incluir o habeas data no texto constitucional, de 1988, e transcreve o artigo 35 da Constituição portuguesa, promulgada em 2 de abril de 1976, ao lado de trecho da mencionada lei paulista, que entrou em vigor dez anos depois da vigência da nova ordem constitucional lusitana.

A transcrição dos trechos da Constituição portuguesa, de 1976, e da Lei Estadual $n^{\circ}$ 5.446, de 19 de dezembro de 1986, encontrada no livro de Tourinho Filho, permite notar coincidências e dissonâncias entre elas, sem falar no grau de alcance das normas, uma firmada por texto constitucional e outra por legislação de Estado membro.

Entre as dissonâncias, verifica-se que o legislador paulista não conseguiu editar dispositivo expresso que impedisse a terceiros acessar os arquivos com dados pessoais, como relativamente regulado em Portugal, nem limitou o emprego da informática para tratamento dos dados individuais sensíveis, providência importante diante do seu avanço e da facilitação da interconexão de dados entre os arquivos informatizados.

As coincidências dos textos, por outro lado, resultam da adoção de regras para garantir o direito de tomar conhecimento do que constar dos registros informáticos a respeito do interessado, conhecer a finalidade do emprego dessa informação e assegurar o direito à retificação e à atualização dos dados incorretos.

A legislação paulista e o texto da Constituição portuguesa não exerceram influência

${ }^{557}$ Lei $\mathrm{n}^{\mathrm{o}} 5.446$, de 19 de dezembro de 1986.

${ }^{558}$ TOURINHO FILHO, Fernando da Costa. Processo penal. 30. ed. São Paulo: Saraiva, 2008. v. 2, p. 198. 
suficiente sobre o Legislador Constituinte brasileiro, de 1988, que permitisse a ampliação das bases constitucionais do habeas data, embora existisse proposta de redação que apresentava texto semelhante àquele adotado pela Constituição portuguesa, trazida pelo Anteprojeto de Notáveis, da Comissão Afonso Arinos. ${ }^{559}$

No Estado de São Paulo, o direito de acesso do cidadão às informações pessoais posteriormente foi tratado pela Lei $\mathrm{n}^{\mathrm{o}} 5.702$, de 5 de junho de $1987,{ }^{560}$ revogada pela Lei $\mathrm{n}^{\mathrm{o}}$ 10.177 , de 30 de dezembro de $1998,{ }^{561}$ que tratou o processo administrativo no âmbito da administração pública estadual.

A comparação entre essas leis estaduais e a leitura das seções VI e VII da lei em vigor, que tratam do procedimento para obtenção e retificação de informações pessoais, indicam ampliação do direito de acesso do cidadão aos informes pessoais e da alteração dessas informações pela administração pública mediante procedimento administrativo.

A Lei $\mathrm{n}^{\mathrm{o}}$ 10.177, de 1998, regula o direito de acesso aos dados reunidos em "qualquer espécie de fichário ou registro, informatizado ou não, dos órgãos ou entidades da Administração, inclusive policiais", enquanto a legislação revogada indicava ser acessível "qualquer fichário dos órgãos da administração direta ou indireta do Estado, inclusive fichários policiais", sem facultar, expressamente, o direito de acesso aos arquivos quando informatizados. O artigo 79 da mesma legislação também estipulou que, caso a administração responder requerimento do interessado ocultando informações a respeito do solicitante, ficará vedado empregá-las em procedimentos eventualmente instaurados contra referida pessoa. ${ }^{562}$

Nota-se que os textos dessas leis estaduais, tanto a revogada quanto aquela em vigor, asseguraram, expressamente, ao cidadão conhecer e retificar informações pessoais inseridas no fichário ou registro policial, reforçando a necessidade de facultar-se ao cidadão acesso e não lhe negar a iniciativa para influir nesse sistema de dados, no caso de existir erro ou incorreção.

Depois de analisar a inserção do habeas data na Constituição brasileira e acompanhar o tratamento legislativo referente ao acesso e à retificação administrativa das

\footnotetext{
${ }^{559}$ CLÉVE, Clémerson Merlin, op. cit., p. 75-77.

${ }^{560}$ GARCIA, Maria. Habeas data: o direito à informação. In: WAMBIER, Teresa Arruda Alvim (Coord.). Habeas data. São Paulo: RT, 1998. p. 230-231.

${ }_{561}^{562}$ Lei $n^{\circ} 5.702$, de 5 de junho de 1987, revogada pela Lei $\mathrm{n}^{\circ} 10.177$, de 30 de dezembro de 1998.

562 “Art. 79 - Os dados existentes, cujo conhecimento houver sido ocultado ao interessado, quando de sua solicitação de informações, não poderão, em hipótese alguma, ser utilizados em quaisquer procedimentos que vierem a ser contra o mesmo instaurados."
} 
informações pessoais no Estado de São Paulo, é importante observar a relação daquele instituto ao registro criminal, partindo da normatização trazida pela Lei Federal $n^{0}$ 9.507, de 12 de novembro de 1997, e da idéia de que o registro criminal é o acervo de dados de natureza criminal mantido por entidades governamentais, no qual as informações reunidas estão acessíveis a terceiros, considerados os integrantes dos órgãos policiais, os juízes de direito e os membros do Ministério Público, além do próprio interessado, que poderão, legitimamente, conhecê-las.

A feição constitucional e a interpretação da Lei $n^{0}$ 9.507, de 1997, permitem verificar que o direito para ajuizar o habeas data é personalíssimo, pois "somente o interessado, isto é, aquele que tem seus dados pessoais registrados, pode valer-se da ação de habeas data, para conhecê-los, obter sua retificação, contestá-los ou justificá-los" não podendo requerer em seu nome membros da própria família ou admitir-se sucessão do direito de pedir. ${ }^{563}$

Considerar que o habeas data pode ser impetrado exclusivamente pelo interessado, conforme dispõe a lei e a doutrina, é interpretação incensurável.

Entretanto, no caso de morte do interessado, deveria ser permitido que o habeas data ajuizado objetivando conhecer e retificar dados inseridos no registro criminal fosse apresentado pelo cônjuge, ascendente, descendente ou irmão do interessado. ${ }^{564}$ Poderia, ao menos, ser permitida a substituição, no caso de a morte do interessado ocorrer depois do ajuizamento do pedido.

Essa proposição se funda na seguinte razão: a informação inserida no registro criminal, embora esteja relacionada à vida privada, reflete no conceito social e atinge a memória do morto, justificando a idéia apresentada, inspirada na disciplina da revisão criminal tratada pelos artigos 623 do Código de Processo Penal ${ }^{565}$ e 553 do Código de Processo Penal Militar, ${ }^{566}$ que permite o ajuizamento do pedido por terceiro, no caso da morte do condenado, e sua continuidade, caso o falecimento do réu ocorrer durante a

${ }^{563}$ TUCCI, Rogério Lauria. Processo e procedimento na ação de habeas data. In: WAMBIER, Teresa Arruda Alvim (Coord.). Habeas data. São Paulo: RT, 1998. p. 335-336.

564 'Em se tratando de 'dado pessoal' - ou personalíssimo -, somente a pessoa em cujo nome constar o registro tem legitimidade ativa ad causam ou legitimação para agir. Exceção feita aos mortos, quando, então, o herdeiro legítimo ou cônjuge supérstite poderão impetrar o writ (STJ - HD - Rel. Milton Pereira - DJU 02.05.89)" [FRANCO, Alberto Silva; STOCO, Rui (Coord.), Código..., cit., v. 1, p. 783-784].

565 "Art. 623 - A revisão poderá ser pedida pelo próprio réu ou por procurador legalmente habilitado ou, no caso de morte do réu, pelo cônjuge, ascendente, descendente ou irmão."

566 “Art. 553 - A revisão poderá ser requerida pelo próprio condenado ou por seu procurador; ou, no caso de morte, pelo cônjuge, ascendente, descendente ou irmão." 
tramitação da revisão criminal. ${ }^{567}$

Entender de outro modo, sem regular o cancelamento do registro criminal pela comprovação da morte do interessado e sem fixar prazo limite para o expurgo das informações, torna permanente e inacessível a anotação inserida, contrariando a idéia de ser o registro criminal arquivo que deve compilar informações enquanto úteis para os fins amplos da persecução penal.

Seguindo na análise de alguns preceitos próprios do habeas data regulados pela Lei Federal $\mathrm{n}^{\mathrm{o}}$ 9.507, de 12 de novembro de 1997, aplicáveis ao registro criminal, cabe salientar que o pedido de habeas data deverá ser instruído com prova do indeferimento ou não-apresentação da resposta ${ }^{568}$ ao pleito administrativo previamente enviado pelo interessado ao responsável do órgão que compile o registro criminal. Essa providência é necessária, pois a obtenção e a correção administrativa das informações poderão ter resultado mais rápido e eficiente, se comparadas à tramitação de pedido jurisdicional.

Se a regra a ser observada é que o detentor da legitimação ativa para o pedido de habeas data é o interessado, passivamente, estarão legitimados para essa ação qualquer órgão público, pessoa ou entidade de direito privado, desde que conservem registros ou bancos de dados públicos, seja no âmbito federal, estadual ou municipal, inseridos entre eles os órgãos ligados aos Poderes Legislativo e Judiciário, bastando que as informações arquivadas sejam acessíveis a terceiros, de modo habitual ou relativo. ${ }^{569}$

É necessário que as informações que se pretenda conhecer, retificar ou inserir integrem registro ou banco de dados públicos, pois o emprego dessa ação constitucional foi considerado inadequado para atender interesse de candidato que pretendia conhecer as razões do indeferimento da sua inscrição em concurso público, porque mencionado indeferimento não é informação que deva integrar registro ou banco de dados públicos, ${ }^{570}$ bem como também já foi considerado meio inidôneo para alcançar agilização da tramitação

${ }^{567}$ FRANCO, Alberto Silva; STOCO, Rui (Coord.), Código..., cit., v. 1, p. 855.

${ }^{568}$ O parágrafo único do artigo $8^{\circ}$ da Lei $\mathrm{n}^{\circ}$ 9.507, de 1997, traz essa exigência e dispõe que, transcorrido o período de dez ou quinze dias sem resposta ou providência, conforme a modalidade do pedido administrativo, é admissível o ajuizamento do habeas data.

${ }_{570}^{5}$ TUCCI, Rogério Lauria, op. cit., p. 336 e 339.

570 Nesse sentido já foi decidido que: "Concurso público - Inscrição indeferida - "Habeas data" impetrado pelo candidato para apurar as razões ou motivos da decisão - Meio inidôneo - Inexistência de registro e banco de dados perpetuando informações sobre o interessado - Mera investigação no interesse da instituição, em caráter interno, e, portanto, sem veiculação do apurado" (BRASIL. Tribunal de Justiça. Habeas Data n 1/90, Relator: Des. Mauro José Pereira, Mato Grosso, MS, 8 de março de 1990. Revista dos Tribunais, n. 668, p. 138, jun. 1991). Entretanto é possível imaginar que se qualquer entidade governamental ou de caráter público agir de modo discriminatório e, por exemplo, reunir dados das pessoas impedidas de habilitar-se a concurso em arquivo público, mostra-se admissível o habeas data para o interessado conhecer e retificar esse registro. 
processual obter informações sobre o andamento de processo ou cópias xerográficas de autos. $^{571}$

Os informes inseridos no registro criminal podem ser transmitidos a terceiros, consideradas as pessoas que representam determinados órgãos institucionais, como a Polícia, a Justiça e o Ministério Público, além do próprio interessado.

Em relação ao fornecimento de dados ao próprio interessado, é importante ressaltar ser comum órgãos públicos e particulares condicionarem deferir alguma pretensão da pessoa interessada à apresentação das informações criminais pelo interessado, obtidas por ele próprio perante os órgãos responsáveis pela expedição dos informes e certidões criminais.

Essa exigência, por via oblíqua, transfere a órgãos públicos e particulares informações criminais que de outro modo não seriam por eles conhecidas. Essa afirmação permite raciocinar e obriga admitir ser o registro criminal arquivo de caráter público, mas controlado o acesso ao conteúdo. Classificá-lo de outro modo, afastaria a incidência do habeas data, particularmente diante do texto do parágrafo $1^{\circ}$ do $\operatorname{artigo} 1^{\circ}$ da Lei $\mathrm{n}^{\circ} 9.507$, de $1997,{ }^{572}$ e impediria ao interessado recorrer ao mencionado remédio constitucional para conhecer e retificar dados pessoais criminais inseridos no registro criminal.

O registro criminal brasileiro é composto e mantido pela somatória dos esforços das entidades públicas envolvidas, amplamente, na persecução penal, porque sua atualização demanda ações da Polícia, do Ministério Público e da Justiça.

No Brasil, preservam-se arquivados, organizados e acessíveis os dados relativos ao envolvimento criminal de qualquer pessoa pela ação conjugada dos órgãos comprometidos a persecução penal acima mencionados, pois neles é possível notar interesse comum em conhecer informações para ampliar a eficiência da missão que lhes é reservada. Isso ocorre especialmente em relação à Polícia, mas não deixa de atingir o promotor de Justiça e juiz de direito em determinada fase do exercício das tarefas que lhes são impostas pela legislação criminal, como ocorre no momento de impor sanção, quando a informação fornecida com rapidez e segurança pelo registro criminal permite conhecer eventuais envolvimentos criminais anteriores das pessoas sob julgamento, para adequada fixação da

\footnotetext{
${ }^{571}$ FRANCO, Alberto Silva; STOCO, Rui (Coord.), Código..., cit., v. 1, p. 783-784.

572 "Art. $1^{\circ}$ (VETADO)

Parágrafo único. Considera-se de caráter público todo registro ou banco de dados contendo informações que sejam ou que possam ser transmitidas a terceiros ou que não sejam de uso privativo do órgão ou entidade produtora ou depositária das informações."
} 
pena.

A dificuldade de apontar o exato órgão da entidade governamental responsável pelo registro criminal não pode servir como argumento para excluir a pessoa que necessite conhecer e retificar os dados nele inseridos da proteção do habeas data. Reforça essa afirmação a correta interpretação dada aos incisos XXXIV e LXXII do artigo $5^{\circ}$ da Constituição Federal e a conclusão de que o serviço de proteção ao crédito se equipara à entidade de caráter público. ${ }^{573}$

Aproveitando o raciocínio acima mencionado, cabe entender que, se a informação relativa ao crédito pessoal, reunida em arquivo normalmente mantido por associações comerciais, pode ser alcançada pelo habeas data, é razoável supor que esse remédio sirva para assegurar o direito de obter informe e retificação do registro criminal, porque nele se depositam dados criminais cujo conhecimento e retificação podem interessar ao titular dos dados para evitar a divulgação a terceiros, a redução do seu prestígio social e dificuldades para sua inserção no mercado de trabalho, efeitos que também podem ser trazidos pelas informações desfavoráveis quanto ao crédito.

Ao finalizar o estudo do habeas data, previsto no Brasil pela Constituição Federal, de 1988, e regulado pela Lei no 9.507, de 1997, convém ressaltar seu emprego estrito para conhecer, retificar ou inserir dados no registro criminal. Entretanto, sem contemplar, expressamente, a possibilidade da aplicação para cancelar ou eliminar dados do registro criminal, por exemplo, caso comprovada a desnecessidade da manutenção das informações, referida ação constitucional deveria ser admitida para tal finalidade, ou seja, cancelamento ou eliminação dos dados do registro criminal, providência a ser considerada, em sentido amplo, como uma forma para alcançar a retificação daqueles dados e preservar o sigilo dessas informações.

Noutro sentido, determinados aspectos importantes relacionados ao manejo do habeas data ficaram sem previsão legal, como a regulação da hipótese em que terceiros poderiam acessar registros de dados alheios e a restrição da interconexão dos dados entre os arquivos computadorizados.

Apesar disso, a previsão constitucional e a normatização legal do habeas data permitem seja ele empregado pelo interessado que desejar conhecer, retificar ou inserir

\footnotetext{
${ }^{573}$ Tribunal de Justiça de São Paulo, Apelação Cível no 223.380-1, Relator Oliveira Prado, julgada em 16 de agosto de 1995 (LOPES, Maurício Antonio Ribeiro; LOPES, Vera Maria de Oliveira Nusdeo. Ementário sobre o habeas data. In: WAMBIER, Teresa Arruda Alvim (Coord.). Habeas data. São Paulo: RT, 1998. p. 437).
} 
dados no registro criminal. É provável que o uso do habeas data nesse campo possa ser ampliado se juízes e tribunais compreenderem a existência, a finalidade e o funcionamento do registro criminal e no campo constitucional e processual penal o cotejarem ao direito à privacidade, limitando a utilização dos dados do registro criminal para comprovar reincidência, maus antecedentes e atender outra finalidade legal na esfera criminal, como a avaliação da idoneidade de jurados e peritos criminais.

\subsection{Mandado de segurança, habeas corpus e registro criminal}

Necessário, a seguir, o exame do mandado de segurança ${ }^{574}$ individual, pois é usual seja ele empregado pelo interessado em obter decisão judicial que permita alterar ou excluir determinada anotação do registro criminal.

São extraídas da jurisprudência nacional diversas decisões que admitem o uso do mandado de segurança para assegurar direito líquido e certo do impetrante relacionado ao registro criminal, tanto que alguns julgados nesse sentido constam das referências anteriormente feitas neste estudo. ${ }^{575}$

Além delas, é possível encontrar outras decisões que mostraram a aplicabilidade do mandado de segurança a diversas situações relacionadas ao registro criminal, como pedido de cancelamento de distribuição criminal, requerimento da expedição de certidão limitada no tempo, obtenção de decreto de sigilo dos registros criminais após a absolvição, reabilitação, arquivamento do inquérito e trancamento de ação penal. ${ }^{576}$

Tratando o registro criminal de acervo de dados mantido e controlado pelo Poder Público, será considerada ato de autoridade para efeito do ajuizamento de mandado de segurança visando alterar ou excluir anotação desse registro a determinação do agente público com o fim de inserir nome de pessoa relacionado à prática de crime no mencionado registro criminal. ${ }^{577}$

\footnotetext{
574 O mandado de segurança é considerado "remédio constitucional, com natureza de ação civil, posto à disposição de titulares de direito líquido e certo, lesado ou ameaçado de lesão, por ato ou omissão de autoridade pública ou agente de pessoa jurídica no exercício de atribuições de Poder Público" (SILVA, José Afonso, op. cit., p. 391).

${ }^{575}$ Vide notas de rodapé $\mathrm{n}^{\mathrm{os}} 7$ referente ao Recurso Ordinário em Mandado de Segurança $\mathrm{n}^{\mathrm{o}} 16.202 / \mathrm{SP}, 8$, e 18 concernente ao Recurso Ordinário em Mandado de Segurança n ${ }^{\circ} 6.761 / \mathrm{SP}$.

${ }^{576}$ FRANCO, Alberto Silva; STOCO, Rui (Coord.), Código..., cit., v. 1, p. 808-809.

577 "Ato de autoridade é toda manifestação ou omissão do Poder Público ou de seus delegados, no desempenho de suas funções ou a pretexto de exercê-las. Por autoridade entende-se a pessoa física investida de poder de decisão dentro da esfera de competência que lhe é atribuída pela norma legal" (MEIRELLES,
} 
A inclusão do nome de pessoa no registro criminal é freqüentemente determinada por juiz de direito, razão pela qual comum seja este colocado como impetrado em mandado de segurança destinado a alterar o registro criminal. É a autoridade judicial quem expede, de modo definitivo, determinação para inserir anotação no arquivo criminal. ${ }^{578}$

Outra exigência para a viabilidade do mandado de segurança que pretenda alterar ou excluir anotação do registro criminal se liga à existência de direito líquido e certo de obter provimento jurisdicional que permita alterar ou excluir dado determinado desse registro.

Nesse ponto, a jurisprudência é divergente. É possível encontrar decisão proferida em mandado de segurança relacionado ao registro criminal que considera que o impetrado absolvido, sem distinção da fundamentação, "tem o direito de o fato não ser objeto de conhecimento de terceiro, salvo com autorização judicial", 579 enquanto outra decisão considerou impossível o cancelamento de registros policiais, ao afirmar que "o fato de ter sido a ação penal trancada no Tribunal por falta de justa causa não gera para a parte direito líquido e certo ao cancelamento desses dados". 580

A análise realizada, especialmente a partir do exame dos julgados que foram referidos nesse trecho da exposição, serve para demonstrar que o mandado de segurança é um dos mecanismos freqüentemente utilizados pelos interessados em alcançar alteração ou exclusão dos dados pessoais do registro criminal.

Finalmente, cabe fazer sucinta análise do habeas corpus empregado para corrigir situação geradora de constrangimento ilegal relacionada ao registro criminal.

O habeas corpus, "remédio destinado a tutelar o direito de liberdade de locomoção, liberdade de ir, vir, parar e ficar" ${ }^{581}$ foi admitido pela $5^{\text {a }}$ Turma do Superior Tribunal de

Hely Lopes. Mandado de segurança, ação popular e ação civil pública. 11 ed. São Paulo: RT, 1987. p. 8).

${ }^{578}$ No sentido de ser, sob a ótica analisada, o juiz de direito considerado autoridade coatora em mandado de segurança, é possível verificar os seguintes julgados: a) BRASIL. Tribunal de Justiça. Mandado de Segurança $n^{\circ}$ 440.517-3/0-00, Relator: Damião Cogan, da $5^{\text {a }}$ Câmara Criminal, São Paulo, SP, 26 de março de 2004. Por unanimidade de votos. Jurisprudencia do Tribunal de Justiça, São Paulo, v. 279, p. 653-658, ago. 2004; b) BRASIL. Tribunal de Justiça. Mandado de Segurança $n^{\circ} 438.372 .3 / 7 . .$. , cit.; c) BRASIL. Superior Tribunal de Justiça. Recurso Ordinário em Mandado de Segurança $n^{0}$ 7.220/SP, Relator: Edson Vidigal, da $5^{\text {a }}$ Turma, Brasília, DF, 23 de setembro de 1996. Disponível em: $<$ http://www.stj.jus.br/webstj/Processo/stjimagem/frame.asp?browser+true?vPortalAreaPai+289\&vPortalAre a+338\&vPortalAreaRaiz+>. Acesso em: 20 set. 2008.

${ }^{579} \mathrm{O}$ trecho colocado entre aspas foi extraído da ementa do acórdão proferido no Recurso Ordinário em Mandado de Segurança ${ }^{\circ}$ 6.761/SP (BRASIL, Superior Tribunal de Justiça..., cit.).

${ }^{580}$ Recurso Ordinário em Mandado de Segurança no 7.220/SP (BRASIL, Superior Tribunal de Justiça..., cit.). Desse julgado cabe destacar também que o relator, ao empregar argumentação secundária para sustentar o indeferimento do pedido e considerar impossível o cancelamento de registros policiais, afirmou que o caso demandava habeas data e não mandado de segurança.

${ }^{581}$ SILVA, José Afonso, op. cit., p. 390. 
Justiça ao acatar pedido de alteração do registro criminal em sede de recurso ordinário. ${ }^{582}$ Entretanto, em outra oportunidade, a $6^{\text {a }}$ Turma desse tribunal entendeu descabido empregálo para discutir a legalidade da inclusão do nome do paciente no cadastro do Serviço Nacional de Informações Criminais (SNIC), no caso de extinção da punibilidade por falta de representação do ofendido. ${ }^{583}$

Merece referência um julgado que, apesar de indeferir pedido de cancelamento de anotação no arquivo criminal do Instituto de Identificação paulista decorrente de processo criminal que resultou em absolvição, pois embora criticasse o ajuizamento de habeas corpus no lugar de mandado de segurança, ponderou com acerto que "melhor será esquecermos as filigranas e analisarmos, de pronto, a questão proposta, que é simples e não permite que se faça maiores digressões". 584

Não se trata de pregar o uso indistinto de qualquer ação constitucional por outra, mas verificar qual a providência jurisdicional é pretendida e, principalmente, se há fundamento para eventual deferimento do pedido.

Além disso, se a liberdade do requerente for restringida por ato de autoridade e seu registro criminal for maculado por anotação indevida, será admissível o ajuizamento do habeas corpus para preservação do risco à liberdade e saneamento da incorreção registral. Essa situação pode ocorrer se os dados de identificação de determinada pessoa forem utilizados indevidamente por outrem, gerando indevida decretação de prisão preventiva, anotação da existência de investigação e processo no registro criminal do inocente. Nessa hipótese, não seria razoável exigir-se impetração de habeas corpus para preservar a liberdade e outro pedido judicial visando excluir a anotação indevida do registro, bastando que, ao ajuizar o primeiro, cumule-se, expressamente, pedido para correção do cadastro criminal.

Conforme foi visto no capítulo anterior, o habeas data mostra-se instrumento apropriado para retificar dados indevidamente lançados no registro criminal, situação

\footnotetext{
${ }^{582}$ Vide nota de rodapé $\mathrm{n}^{\mathrm{o}} 7$ referente ao Recurso Ordinário em Habeas Corpus $\mathrm{n}^{\circ}$ 14.376/SP.

583 A ementa do julgado foi assim redigida: "Habeas corpus. Indiciamento. Arquivamento do procedimento. Registro no Serviço Nacional de Identificação Criminal. 1. A par de não representar ofensa ao direito de ir e vir a justificar a utilização da via do habeas corpus, a baixa do registro no SNIC é excludente de qualquer ilegalidade a ser reparada. 2. Ordem denegada. RECURSO ORDINARIO EM HABEAS CORPUS NÚMERO 8575 UF SP DTDE 19990601CORG T6 ORG SEXTA TURMA. RELATOR FERNANDO GONÇALVES. FONTE DJ DATA:21/06/1999 PG:00203" (Publicações Eletrônicas Associação Paulista do Ministério Público. São Paulo: APMP, 2004-2006. 1 CD-ROM. Produzido por Eduardo Roberto Alcântara Del-Campo e Marinilce Araújo Soria).

${ }^{584}$ BRASIL. Tribunal de Justiça. Habeas Corpus $\mathrm{n}^{\mathrm{o}}$ 462.544-3/3-00, Relator: Ricardo Tucunduva, da $6^{\mathrm{a}}$ Câmara Criminal, São Paulo, SP, 12 de agosto de 2004. Por unanimidade de votos. Jurisprudência do Tribunal de Justiça, São Paulo, v. 283, p. 539-541, dez. 2004.
} 
diversas vezes sanada pelo mandado de segurança ou habeas corpus.

A freqüência dos pedidos dirigidos aos juízes por meio do habeas data, mandado de segurança ou habeas corpus visa alterar informações escritas contidas no registro criminal, mas poderão ser objeto de exame jurisdicional outros dados pessoais que integrem o arquivo, porque o arquivo de dados criminais poderá incluir dados não-escritos como a imagem fisionômica. Convém considerar ser cabível que a pessoa sem envolvimento criminal se insurja contra o uso da sua fisionomia para compor álbum fotográfico com a coleção dos suspeitos da prática de determinado crime, mantido por repartição policial investigativa. Nessa hipótese, é possível ao interessado impetrar habeas data, se necessário confirmar a inclusão indevida da sua imagem nesse catálogo e em seguida requerer a remoção da fotografia do mencionado álbum.

\subsection{Descriminalização}

No Brasil, em relação a fato que lei posterior deixa de considerar crime cessam a execução e os efeitos penais da sentença condenatória conforme dispõe o artigo $2^{\circ}$, caput, do Código Penal.

A descriminalização gera o abandono do juízo de desvalor à conduta anteriormente classificada como crime. A informação inserida no registro criminal não deve ser divulgada para fins administrativos e particulares, pois nessa hipótese cessam as razões de prevenção especial negativa, isto é, desaparece a necessidade de a administração e os particulares conhecerem a probabilidade da prática de crimes. Identicamente, é cabível vedar-se o fornecimento da anotação referente a conduta descriminalizada para fins processuais, porque o mero conhecimento pelo juiz de sentença penal anterior, mesmo alcançada pela descriminalização, poderia causar maior rigor punitivo em relação ao novo delito. $^{585}$

Na Espanha, foi considerado possível eliminar do Registro Central de Penados y Rebeldes, com base em normatização fixada por legislações anteriores, as anotações relacionadas à prática de fato que o Código Penal e a legislação especial deixaram de considerar criminoso, como ocorreu em relação ao crime de adultério. ${ }^{586}$

\footnotetext{
${ }^{585}$ COSTA, António Manuel de Almeida, op. cit., p. 361-364.

${ }^{586}$ Francisco Bueno Arús (op. cit., p. 135) menciona como situação que também gerou a eliminação da anotação do registro de antecedentes o caso da descriminalização do "cheque en descubierto" e estende esse
} 
A sedução, o rapto e o adultério foram descriminalizados no Brasil pela Lei $n^{\circ}$ 11.106, de 2005, que entre outras providências, revogou os artigos 217, 219 até 222 e 240, todos do Código Penal, mas referida legislação não autorizou, expressamente, o cancelamento automático do registro criminal daqueles eventualmente condenados pela prática desses crimes.

Esse efeito poderia ser alcançado caso fosse interpretada, extensivamente, a regra da abolitio criminis traçada no parágrafo único, do artigo $2^{\circ}$, do Código Penal. ${ }^{587} \mathrm{~A}$ partir desse entendimento o interessado ou o Ministério Público poderia provocar o juiz determinar a alteração do registro no mesmo momento em que requer a extinção da punibilidade com base no artigo 107, inciso III, do Código Penal.

Cancelar dados do registro criminal em razão da descriminalização do crime que deu origem à anotação preserva os dados para eventuais estudos estatísticos e científícos, mas essa providência se mostra factível, em larga escala, somente se os dados do registro criminal estiverem plenamente informatizados. Caso contrário, a entrada em vigor de lei que promova abolitio criminis permitirá o cancelamento do registro ao se atender requerimentos judiciais individualmente apresentados pelos interessados.

\subsection{Idade e morte}

Refere-se que determinados países incluem em suas legislações normas reguladoras do cancelamento ou eliminação do registro criminal pelo atingimento de determinada idade. $^{588}$

Essa postura se funda no amortecimento da prevenção especial negativa que

efeito para a hipótese de despenalização de qualquer conduta da categoria de delito para classificá-la como falta, que parece assemelhar-se à contravenção penal do direito pátrio. Cf., também, GROSSO GALVAN, Manuel, op. cit., p. 334.

${ }^{587}$ Damásio Evangelista de Jesus (op. cit., p. 6) indica que "a condenação é registrada e lançado o nome do réu no rol dos culpados, ato que permite a documentação da decisão condenatória para que produza seus efeitos secundários. Ocorrendo a abolitio criminis, a condenação é declarada inexistente e o nome do condenado é riscado do rol de culpados: o comportamento, como conduta punível, deixa de figurar em sua vida pregressa. Se vier a praticar outra infração, a conduta anterior, tornada inexistente, não o poderá prejudicar." Aquilo que o autor considera como "riscar" o nome do condenado do rol de culpados deve ser compreendido como eliminar ou apagar a referência feita ao fato no registro criminal.

${ }^{588} \mathrm{Na}$ Espanha, em 1925 foi estabelecida norma que permitiu a eliminação das anotações inseridas no registro criminal das pessoas maiores de 70 anos e que não estivessem cumprindo pena (GROSSO GALVAN, Manuel, op. cit., p. 120). Na Argentina, o cancelamento dos dados do registro é permitido ao ser constatado que o titular do registro atingiu 100 anos de idade (ARGENTINA. L. 22117 - Registro Nacional de Reincidencia. Disponível em: <http://consulex.com.ar/Legislacion/Leyes/L0022117.htm>. Acesso em: 3 jan. 2008). 
decorre do alcance de idade avançada e conseqüente redução das energias como resultado do envelhecimento, tornando desnecessário esse mecanismo de defesa social em relação aos idosos. $\mathrm{O}$ argumento favorável à adoção dessa medida se baseia no resultado do descongestionamento dos serviços a começar do cancelamento do registro das pessoas a partir de determinada idade, mas se admite que o emprego da informática é providência que permite alcançar esse efeito mais facilmente. A análise criteriosa indica inexistir fundamento suficiente para apontar a idade avançada como causa para cancelar o registro criminal. $^{589}$

Em reforço à idéia de não ser adequado fixar idade limite para exclusão dos dados da pessoa do registro criminal, pode ser somado o argumento da ampliação da longevidade do homem pela melhoria das condições de vida.

A legislação portuguesa vigente, que trata da identificação e do registro criminal, não fixa idade a partir da qual se cancelam ou se eliminam os dados dos arquivos criminais. $^{590}$

Afirmar-se que a idade avançada e a presumível diminuição das energias reduzem a necessidade de defesa social referente ao idoso, também é entendimento que não se mostra linear para todas as pessoas e em relação a todos os crimes, cabendo mencionar, por exemplo, que a idade avançada, normalmente, não dificultará a ação do agente que organiza a atuação dos grupos envolvidos com a criminalidade organizada cuja prática pode dispensar vigor físico.

A formação e a manutenção do arquivo relativo aos atos infracionais praticados por aqueles que não atingiram idade compatível com a maioridade penal, ou seja, adolescentes, é assunto que ultrapassa os limites deste estudo e, portanto, não será discutido.

Em relação à morte, é possível verificar que ela é causa para o cancelamento do registro criminal admitida pela legislação de vários países, encontrando como fundamento o desaparecimento de exigências preventivo-especiais com reflexo na dispensa do fornecimento da informação para fins particulares, administrativos e processuais. ${ }^{591}$

No Brasil, o cancelamento do registro criminal a partir da comprovação da morte não é providência expressamente prevista pela lei, mas referida posição deve ser extraída da qualificação da morte como causa extintiva da punibilidade, efeito previsto no artigo

\footnotetext{
${ }^{589}$ COSTA, António Manuel de Almeida, op. cit., p. 366-367.

${ }^{590}$ VEIGA, Catarina, op. cit., p. 145-158.

${ }^{591}$ COSTA, António Manuel de Almeida, op. cit., p. 364-365.
} 
107, inciso I, do Código Penal.

Ao extinguir o procedimento pela morte do agente, elimina-se o motivo que sustentaria o acesso ao registro criminal da pessoa investigada ou acusada, exceto na hipótese da revisão extraordinária da sentença condenatória a requerimento dos parentes ou herdeiros do morto nos termos do artigo $675^{\circ}$ do Código de Processo Penal português. ${ }^{592}$

No Brasil, a revisão criminal pós-morte do acusado pode ser requerida por seu cônjuge, ascendente, descendente ou irmão. ${ }^{593}$

Na Espanha, em 1925 se editou norma que permitiu a eliminação das anotações inseridas no registro criminal dos condenados falecidos. ${ }^{594}$ Frisa-se que a Espanha permite eliminar os antecedentes penais do morto, ${ }^{595}$ enquanto em Portugal, a notícia do falecimento do argüido condenado é fato sujeito a registro criminal nos termos do artigo $5^{\circ}$, número 2, alínea "b", da Lei 57/98, de 18 de Agosto. ${ }^{596}$

A descriminalização e a morte, em razão de produzirem efeitos extintivos da punibilidade, deveriam ser, expressamente, previstas pela legislação nacional como causas geradoras não somente do cancelamento do registro criminal, mas da sua eliminação, providência que seria determinada pelo juiz ex officio ou para atender pedido do órgão do Ministério Público, da defesa, do interessado, cônjuge, ascendente, descendente ou irmão.

\subsection{Pena suspensa, anistia e prescrição}

A suspensão condicional da pena ${ }^{597}$ somente permitirá impedir o conhecimento do registro criminal em relação ao acesso dos particulares e de certas autoridades administrativas, assegurando o fornecimento integral da informação se requisitada para fins judiciais e policiais e, especialmente, diante da provisoriedade dessa medida.

No Brasil, existem normas legais que tratam, expressamente, da suspensão condicional da pena no Código de Processo Penal ${ }^{598}$ e na Lei de Execução Penal, ${ }^{599}$

\footnotetext{
${ }^{592}$ COSTA, António Manuel de Almeida, op. cit., p. 365-366.

593 Artigo 623 do Código de Processo Penal.

${ }^{594}$ GROSSO GALVAN, Manuel, op. cit., p. 120.

595 Francisco Bueno Arús (op. cit., p. 78 e 132), aliás, atribui o cabimento de eliminar o registro de antecedentes no caso de morte à legislação mais antiga, ou seja, ao texto do artigo 10 da Real Ordem, de 5 de dezembro de 1892.

${ }^{596}$ VEIGA, Catarina, op. cit., p. 147.

${ }^{597}$ Ver artigos 77-82 do Código Penal.

598 “Art. 709 - A condenação será inscrita, com a nota de suspensão, em livros especiais do Instituto de
} 
atribuindo ao seu registro caráter secreto ou sigiloso, exceto para atender requisição judicial ou do Ministério Público.

A suspensão da pena e o livramento condicional devem ser conhecidos da autoridade policial, pois fica vedada a concessão de fiança ao acusado que cometer novo crime doloso durante gozo de sursis ou livramento. ${ }^{600}$

A anistia, prevista como causa extintiva da punibilidade no artigo 107, inciso II, primeira figura, do Código Penal, é concedida por ato legislativo estatal de renúncia "ao poder-dever de punir o autor do crime, atendendo a razões de necessidade ou de conveniência política" e o seu deferimento "impede o reconhecimento da reincidência quanto aos ilícitos futuros". 601

Manter-se anotado no registro criminal e conceder-se certidão informativa de fato anistiado é contra-senso, faz persistir o efeito estigmatizante e serve como pré-juízo negativo em relação à pessoa beneficiada pelo instituto. Essa posição é injustificável, porque o fato alcançado pela anistia não poderá servir para forjar reincidência, mesmo que em relação a ela exista sentença penal condenatória com trânsito em julgado, afronta o princípio da presunção de inocência, especialmente no caso em que a anistia impediu o julgamento do mérito de ação penal proposta, além de contrapor-se à vontade políticocriminal do legislador que editou o ato legislativo concessivo da anistia com a finalidade de fazer prevalecer a idéia do esquecimento da prática criminosa. Diante desses

Identificação e Estatística, ou repartição congênere, averbando-se, mediante comunicação do juiz ou do tribunal, a revogação da suspensão ou a extinção da pena. Em caso de revogação, será feita a averbação definitiva no registro geral.

$\S 1^{\circ}$. Nos lugares onde não houver Instituto de Identificação e Estatística ou repartição congênere, o registro e a averbação serão feitos em livro próprio no juízo ou no tribunal.

$\S 2^{\circ}$. O registro será secreto, salvo para efeito de informações requisitadas por autoridade judiciária, no caso de novo processo.

$\S 3^{\circ}$. Não se aplicará o disposto no $\S 2^{\circ}$, quando houver sido imposta ou resultar de condenação pena acessória consistente em interdição de direitos."

599 “Art. 163 - A sentença condenatória será registrada, com a nota de suspensão, em livro especial do juízo a que couber a execução da pena.

$\S 1^{\circ}$. Revogada a suspensão ou extinta a pena, será o fato averbado à margem do registro.

$\S 2^{\circ}$. O registro e a averbação serão sigilosos, salvo para efeito de informações requisitadas por órgãos judiciário ou pelo Ministério Público, para instruir processo penal."

600 “Art. 324 - Não será, igualmente, concedida fiança:

I - aos que, no mesmo processo, tiverem quebrado fiança anteriormente concedida ou infringido, sem motivo justo, qualquer das obrigações a que se refere o art. 350;

II - em caso de prisão por mandado do juiz do cível, de prisão disciplinar, administrativa ou militar;

III - ao que estiver no gozo de suspensão condicional da pena ou de livramento condicional, salvo se processado por crime culposo ou contravenção que admita fiança;

IV - quando presentes os motivos que autorizam a decretação da prisão preventiva (art. 312).

* Inciso IV com redação determinada pela Lei n. ${ }^{\circ}$ 6.416, de 24 de maio de 1977" (Código de Processo Penal).

${ }^{601}$ DOTTI, René Ariel. Curso..., cit., p. 674-675. 
argumentos, a concessão da anistia deveria refletir diretamente no registro criminal permitindo o cancelamento do respectivo registro. ${ }^{602}$

A idéia de que a concessão da anistia deva refletir no registro criminal causando o cancelamento da anotação referente ao fato anistiado ainda não foi assimilada pela legislação em Portugal.

Nesse país, embora a Lei 57/98, de 18 de Agosto, que trata da identificação e do registro criminal, não traga previsão para a inscrição da decisão concessiva de anistia no registro criminal, referida providência era prevista pelo Decreto-Lei 39/83, de 25 de Janeiro, que mandava inscrever as "decisões que apliquem amnistias" e fazia perpetuar os efeitos penais que a anistia pretendia evitar. A vigência do texto legal anterior pode ser subentendida pela leitura de trecho da nota introdutória ao Decreto-Lei 381/98, de 27 de Novembro. ${ }^{603}$

É oportuno frisar, no plano do direito comparado, que em países como a Grécia e Suíça a concessão da anistia pode ser anotada somente à margem do registro. Na Bélgica, ela causa cancelamento dos cadastros, gerando os mesmos efeitos da reabilitação. ${ }^{604}$

O conhecimento pelos juízes e tribunais dos crimes anistiados é controvertido, porque o instituto se sustenta na idéia de pacificação social e omitir notícia acerca da existência da concessão da anistia resultaria em prejuízo da sua apreciação, por exemplo, para servir como parâmetro para a medida da pena. Em razão de a anistia poder aplicar-se a fatos que foram objetos de sentença penal condenatória com trânsito em julgado e àqueles que sequer foram julgados, melhor seria que qualquer modalidade dela resultasse no cancelamento do registro criminal para quaisquer fins, inclusive judiciais. Apesar disso, o direito penal português considera a sentença anistiada para fins de reincidência, conforme dispõe o artigo $75^{\circ}$, número 4 , efeito que exigirá, portanto, a inclusão da informação nos certificados extraídos do registro criminal. ${ }^{605}$

$\mathrm{Na}$ Espanha, a anistia resulta na eliminação dos antecedentes criminais, pois referido instituto "extingue todas las consecuencias del delito y produce el olvido del

${ }^{602}$ VEIGA, Catarina, op. cit., p. 83-89.

603 "O funcionamento do registo criminal encontra-se, ainda hoje, regulado pelo Decreto-Lei n. ${ }^{\text {" }} 39 / 83$, de 25 de Janeiro, publicado na seqüência do Código Penal de 1982 com o objectivo de harmonizar o regime do registo criminal com as profundas alterações operadas por este Código, o qual, no entanto, não introduziu alterações profundas no regime anteriormente vigente" (PORTUGAL. Decreto-Lei 39/83, de 25 de Janeiro. Diário..., cit., p. 6576).

${ }^{604}$ COSTA, António Manuel de Almeida, op. cit., p. 231-232.

${ }^{605}$ Id., ibid., p. 334-336. O mencionado dispositivo do Código Penal português está redigido do seguinte modo: "A prescrição da pena, a amnistia, o perdão genérico e o indulto, não obstam à verificação da reincidência” (PORTUGAL. Código Penal..., cit.). 
mismo, se concede por Ley del Legislativo y hace eliminar los antecedentes penales". ${ }^{606}$

No Brasil, em virtude da taxatividade dos incisos I e II do artigo 64 do Código Penal, ao tratar daquilo que não configura reincidência, o registro criminal também deverá informar as decisões anistiadas aos juízes e tribunais, exceto se decisão alcançada pela anistia não possuir conteúdo condenatório.

Em relação à prescrição, não permitir eliminar as anotações do registro no caso de ser reconhecida a prescrição é entendimento considerado na Espanha como redutor da lógica jurídica de que o transcurso do tempo faz desaparecer a pena a ser cumprida e os seus efeitos, sem correspondência da eliminação do registro respectivo. A partir dessa análise foi sugerida alteração legislativa que permita eliminar o registro depois de transcorrido lapso temporal igual ao que gera a prescrição da condenação. ${ }^{607}$

No Brasil, não existe previsão legal que permita cancelar anotações do registro no caso do reconhecimento judicial da prescrição, mas o Superior Tribunal de Justiça corretamente entendeu que essa providência é possível se reconhecida a prescrição da pretensão punitiva. ${ }^{608}$

Entretanto, o cancelamento do registro não será cabível se a punibilidade do agente foi extinta pelo reconhecimento da prescrição da pretensão executória, porque nesse caso é necessário manter anotada a condenação, desde que não ultrapassado o prazo depurador fixado em 5 (cinco) anos pela legislação nacional, pois "a extinção da punibilidade de crime anterior, tão somente para efeitos de cumprimento de pena, não descaracteriza a reincidência". ${ }^{609}$ Cancelar o registro criminal, é providência que não deve causar efeito desproporcional e dificultar o apontamento da reincidência e dos maus antecedentes, sob pena de reduzir-lhe a eficácia.

${ }^{606}$ BUENO ARÚS, Francisco, op. cit., p. 82.

${ }^{607}$ GROSSO GALVAN, Manuel, op. cit., p. 155-156.

${ }^{608}$ BRASIL. Superior Tribunal de Justiça. Antecedentes criminais. Inquéritos arquivados, reabilitação, absolvição e reconhecimento da prescrição da pretensão punitiva. Exclusão de dados do registro de identificação criminal. Direito líquido e certo. Recurso provido. Recurso Ordinário em Mandado de Segurança ${ }^{\circ} 16.202 / \mathrm{SP} . . .$, cit.

${ }^{609}$ BRASIL. Supremo Tribunal Federal. Habeas Corpus no ${ }^{\circ}$ 68.569/DF, Relator: Ministro Celio Borja, da $2^{\mathrm{a}}$ Turma, Brasília, DF, 11 de junho de 1991. Diário Oficial [da] República Federativa do Brasil, Brasília, DF, 16 ago. 1991. p. 10786. 


\subsection{Cancelamento do registro criminal e exclusão da prova}

Uma das finalidades mais marcantes do registro criminal, no âmbito processual penal, é servir como repositório dos antecedentes criminais e fonte principal para, a partir dele, ser obtida prova da existência da reincidência e dos antecedentes.

O direito que as partes têm de introduzir provas no processo penal para convencer o julgador, embora ostente natureza constitucional, não é absoluto. Esse direito à admissão da prova é restrito e limitado pelos demais valores e interesses também protegidos pelo ordenamento jurídico. Excluir provas para atender regras processuais é providência usual no sistema anglo-americano, no qual o julgamento de certos fatos é atribuição de cidadãos comuns que poderiam ser ludibriados por determinada modalidade de prova apresentada, tanto que nele são vedadas as "provas relacionadas aos antecedentes do acusado, que poderiam levar o júri a reconhecer sua culpabilidade em razão de outros fatos, e não aquele pelo qual está sendo efetivamente julgado, e outras". 610

No caso de a anotação ter sido cancelada do registro, ela poderá ser conhecida da polícia, membro do Ministério Público e juiz, pois a regra é não lhes vedar essa informação. ${ }^{611}$

Especialmente, em relação ao juiz, é possível que ele conheça informação referente a determinado processo ou condenação que mais tarde ele próprio confirme esteja relacionada à anotação cancelada do registro criminal. Informação dessa natureza poderá ser levada ao conhecimento do juiz e fixada no processo, por exemplo, na ocasião do interrogatório, da oitiva das testemunhas ou exame de documento apresentado pela acusação.

A prova da reincidência, assunto anteriormente tratado neste estudo, é feita por meio da juntada aos autos do processo criminal da certidão judicial na qual conste, pelo menos, os dados qualificativos do acusado, referências ao processo e ao crime, além da

610 GOMES FILHO, Antonio Magalhães. Direito..., cit., p. 80, 91 e 96. Ainda, segundo o autor, a Constituição Federal brasileira "além de consagrar as tradicionais cláusulas do contraditório e da ampla defesa (art. $5^{\circ}$, inc. LV), também assegura o devido processo legal (art. $5^{\circ}$, inc. LIV) e a presunção de inocência (art. $5^{\circ}$, inc. LVII), dos quais também se extrai o direito de defender-se provando, que não somente é pressuposto de um processo justo e eqüitativo, mas também condição indispensável para que se possa obter, validamente, a prova da culpabilidade" (itálicos originais).

${ }^{611}$ Acerca do cancelamento de ofício das anotações do registro, na Espanha, Francisco Bueno Arús (op. cit., p. 31) comenta que "se anuncia la cercana promulgación de un Real Decreto, pendiente en la actualidad únicamente del informe del Consejo de Estado, que regulará el procedimiento para la cancelación de los antecedentes penales en el Registro, 'apostando por la cancelación de oficio, frente a la mayoritaria a instancia de parte, como actualmente sucede' (Romero Macías)." 
indispensável menção à data em que a condenação transitou em julgado.

Afirma-se, por conseguinte, que as informações canceladas do conteúdo do registro criminal não devem ser valoradas para provar antecedentes desabonadores.

Forçoso admitir, portanto, que o cancelamento da anotação do cadastro criminal impedirá a valoração dessa informação mesmo que o juiz dela tome conhecimento em razão da prerrogativa de ter acesso aos dados cancelados ${ }^{612}$ ou por conhecê-la por outro meio que não o acesso ao registro criminal ou o exame de certidão judicial.

As anotações canceladas deverão ser consideradas "extintas no plano jurídico"613 e delas não deve resultar quaisquer efeitos para fins de recrudescer a sanção a ser imposta, excetuados determinados usos antes referidos, entre eles, especialmente, servir como prova para defesa do acusado.

Excluir a possibilidade do emprego do registro para comprovar antecedentes desabonadores a partir de informação cancelada no registro significa proibir seu uso em juízo e impossibilitar seja levada em consideração, caso indevidamente conhecida pelo juiz ou tribunal.

O cancelamento do conteúdo do cadastro criminal "parece, desde logo, implicar uma proibição de prova quanto aos factos por ele abrangidos". ${ }^{614}$

$\mathrm{Na}$ hipótese de o juiz conhecer os antecedentes do acusado em razão da participação em julgamento de outro processo relativo ao mesmo acusado, ele não deverá utilizá-los para fins probatórios se a informação estiver cancelada no registro. Nessa situação, a não-admissão desse informe para provar reincidência e antecedentes equipara esse conhecimento anterior aos "dados de sua ciência particular", os quais se recomenda ao juiz não utilizar para fins probatórios. ${ }^{615}$

Existem duas previsões na legislação brasileira que impedem o acesso e a

\footnotetext{
${ }^{612}$ No sentido de preservar o juiz de conhecer informações criminais canceladas, nota-se o conteúdo do julgado cuja ementa é a seguinte: "Mandado de segurança - Impetração contra magistrado que indefere pedido de cancelamento de registros criminais existentes em nome do impetrante - Queixas-crime movidas contra este liminarmente rejeitadas por falta de justa causa. Possibilidade de cancelamento, salvo em caso de requisição por autoridade judiciária - Ordem concedida. Se mesmo em caso de condenação a lei penal faz timbre em evitar a estigmatização, para todo o sempre, dos que se viram envolvidos em crimes sem que se evidenciasse periculosidade (arts. 709, § $2^{\circ}$, e 748, do CPP), com maior razão é irrecusável o direito daquele que teve trancada ação penal contra si instaurada, por falta de justa causa, de obter o cancelamento da distribuição do feito, a fim de que apenas sejam expedidas certidões negativas de seus antecedentes, salvo em caso específico de requisição judicial (TACrim - SP - MS 159.832-6 - Rel. Lourenço Filho - JUTACRIMSP 94/465)" [FRANCO, Alberto Silva; STOCO, Rui (Coord.), Código..., cit., v. 1, p. 809].

${ }^{613}$ COSTA, António Manuel de Almeida, op. cit., p. 378 (itálico original).

${ }^{614}$ Id., ibid., p. 378.

${ }^{615}$ GOMES FILHO, Antonio Magalhães. Direito..., cit., p. 91-92.
} 
divulgação, em determinadas situações, dos dados relativos à condenação criminal anterior. Ambas foram editadas sem o objetivo de restringir o direito à produção de prova criminal, mas refletem sobre esse tema, servindo como referência.

A primeira previsão é encontrada na Lei nº 7.805 (Lei de Execução Penal), de 1984, cujo artigo 202 veda a expedição de certidão que faça menção à condenação, se cumprida ou extinta a pena, tema já abordado neste estudo.

A segunda está na Lei $n^{0} 5.250$ (Lei de Imprensa), de 1967, cujo artigo 21, § 2º, equipara ao crime de difamação a "publicação ou transmissão, salvo se motivada por interesse público, de fato delituoso, se o ofendido já tiver cumprido pena a que tenha sido condenado em virtude dele". ${ }^{616}$

Nota-se que a Lei de Execução Penal restringe a expedição de certidão relacionada à condenação anterior cuja pena foi cumprida ou extinta, enquanto a Lei de Imprensa pune a publicação ou transmissão de notícia de fato delituoso relativa à reprimenda cumprida, salvo neste caso se existir interesse público. Essas vedações legais devem servir como referência para limitar a produção e a valoração da prova do antecedente criminal desabonador perante o juiz, na eventualidade do prévio cancelamento da respectiva anotação no registro criminal.

A revelação de fatos relacionados a informações canceladas no registro pela acusação é hipótese que deveria encontrar regulação dentro do sistema de registro criminal, ${ }^{617}$ devendo existir norma expressa que vede essa possibilidade.

A restrição quanto à divulgação da condenação criminal, nas hipóteses da execução penal e da lei dos crimes de imprensa acima mencionadas, sugere a vedação ao emprego dos dados cancelados para provar antecedentes negativos mesmo sem regulação direta pela legislação nacional, pois essa restrição pode ser debatida no campo da limitação do direito à prova.

Esse entendimento, além dos argumentos antes apresentados, foi reforçado por duas alterações recentes do Código de Processo Penal brasileiro.

A primeira delas permitiu, nos procedimentos comuns ordinário e sumário, conforme antes fixado no procedimento sumaríssimo, ao juiz expressamente indeferir

\footnotetext{
${ }^{616}$ Mencionado dispositivo da Lei de Imprensa, além de outros, está com a eficácia suspensa e sob análise do Supremo Tribunal Federal, diante de decisão exarada nos autos da Medida Cautelar nº 130/07 (cit.), mas serve como referência, pois não foi revogado.

${ }^{617}$ COSTA, António Manuel de Almeida, op. cit., p. 354.
} 
provas consideradas irrelevantes, impertinentes ou protelatórias. ${ }^{618}$ Essa regra poderá servir para fundamentar a recusa de o juiz apreciar anotação cancelada do registro criminal para comprovar antecedente negativo sob o argumento de tratar-se de prova impertinente.

A segunda alteração, aplicável ao procedimento relativo aos processos da competência do Tribunal do Júri, dispõe que durante os debates as partes não poderão, sob pena de nulidade, fazer referência, entre outras, "à determinação do uso de algemas como argumento de autoridade" para beneficiar ou prejudicar o acusado. ${ }^{619}$

Esse dispositivo, trazido pela reforma do capítulo do Código de Processo Penal que tratou do júri, inovou com a finalidade de evitar que o jurado pudesse ser impressionado durante os debates por argumento extraído do simbolismo que resulta do uso de algemas.

O legislador poderia ter avançado e também vedado às partes debater em plenário acerca dos antecedentes criminais do acusado visando beneficiá-lo ou prejudicá-lo. Essa restrição impediria fosse o acusado portador de antecedentes julgado por fato diverso daquele pelo qual está sendo processado, conforme mencionado quando da referência feita ao sistema anglo-americano. Além disso, ficaria o jurado isento da avaliação decorrente da existência de anotação no registro criminal, freqüentemente negativa, vedação especialmente justificada se o antecedente criminal estiver cancelado.

${ }^{618}$ Artigo 400, $\S 1^{\circ}$, do Código de Processo Penal, conforme Lei $\mathrm{n}^{\mathrm{o}} 11.719$, de 20 de junho de 2008, e artigo $81, \S 1^{\circ}$, da Lei $n^{\circ} 9.099$, de 1995.

${ }^{619}$ Artigo 478, inciso I, do Código de Processo Penal, conforme Lei no 11.689, de 9 de junho de 2008. 


\section{CONCLUSÕES}

Ao finalizar o estudo do registro criminal sob a ótica da eficiência e do garantismo e verificar seu relacionamento a temas criminais diversos, é momento de extrair sínteses e conclusões que poderão servir para aperfeiçoar a estruturação do registro criminal no processo penal brasileiro, para criar ou alterar a legislação e, também, para modificar paradigmas seguidos por juízes e outros profissionais da área jurídica ao defrontarem-se com questões relacionadas ao registro criminal.

Estas conclusões visam suscitar reflexões sobre o registro criminal brasileiro a começar da sua relativa (des)estruturação e do efeito por ele causado à pessoa submetida à investigação ou processo criminal e a respeito de outra fisionomia que o instituto pode assumir, especialmente, a partir da observância de direitos e garantias constitucionais, do controle ao acesso e do cabimento da exclusão dos dados para restringir a divulgação da informação e dificultar avaliação negativa da pessoa que ostenta anotação, por vezes considerada, precipitadamente, portadora de maus antecedentes criminais.

A começar da análise dos pressupostos constitucionais e dos temas fundamentais relacionados ao registro criminal, são extraídas conclusões a seguir especificadas (Capítulo 1):

A proteção da privacidade e da liberdade da pessoa impõe ao registro criminal estruturar-se de modo a não fornecer informações sem previsão legal, autorização do interessado, determinação judicial ou justa causa.

O emprego do princípio da proporcionalidade para tratar o acesso às informações do registro criminal permite satisfazer com equilíbrio o interesse em obter informações e a proteção aos direitos individuais, gerando eficiência estatal durante a persecução penal sem violação indevida da intimidade e da liberdade da pessoa.

A eficiência e o garantismo são valores incorporados ao moderno processo penal que devem atuar simultaneamente sobre o registro criminal, fazendo pressões simétricas para equilibrar o sistema e permitindo o uso das informações criminais sem impedir a inserção social da pessoa cujo nome nele foi inserido. A eficiência não deve ser medida apenas pela resposta rápida aos pedidos de informações dirigidos ao registro, pois embora celeridade seja característica importante, o sistema, além de veloz, deverá aferir a possibilidade de ofertar a informação ao 
solicitante. O garantismo não deve transformá-lo em arquivo fechado, mas em fonte acessível de dados criminais que funcione conforme padrões constitucionais e legais. Eficiência e garantismo devem orientar o emprego e a regulação do registro criminal, cujas características permitem compará-lo à droga farmacológica, pois do mesmo modo que o medicamento é indispensável para tratar doenças, exigindo pesquisa freqüente para reduzir os efeitos prejudiciais à saúde do usuário, o registro criminal mostra-se necessário ao Direito Processual Penal, porém deve ser empregado minimizando-se efeitos estigmatizantes e negativos.

O conteúdo do registro criminal deve ser considerado como uma espécie de dado sensível individual mantido pelo Estado e dele merecer proteção semelhante às demais informações relacionadas à vida privada, justificando que a legislação nacional classifique o registro criminal como arquivo sigiloso e lhe regule o acesso para evitar busca e fornecimento indevido de dados criminais sem impedir o fornecimento deles se houver interesse público.

A proteção da vida privada proporcionada pelo sigilo do registro criminal é valor e ao mesmo tempo tendência que deveria ser seguida para construção e interpretação desse sistema de armazenamento de dados, a exemplo dos dispositivos legais que impõem sigilo no caso de suspensão condicional da pena e da reabilitação, especialmente diante de inexistir orientação para tratar como público esse arquivo, observado o inciso $\mathrm{X}$ do artigo $5^{\circ}$ da Constituição Federal brasileira que considera inviolável a vida privada.

À defesa e à acusação deve ser assegurado o direito de manifestação sobre documentos e certidões relativos aos antecedentes criminais do acusado, inclusive se juntados depois de encerrada a instrução, garantindo-se o contraditório efetivo, igualmente o princípio constitucional da presunção de inocência deverá incidir sobre a interpretação das informações extraídas do registro criminal.

O registro criminal deve ser instituído, organizado e mantido pelo Estado com o fim de demonstrar a quem se aplicou a Justiça, devendo o legislador estabelecer regras básicas para sua criação, manutenção, funcionamento e acesso, observada a Constituição Federal além das orientações doutrinárias, jurisprudenciais e de direito comparado, pois a divulgação de anotação do registro criminal reduz o conceito social da pessoa, efeito que deverá ser minimizado sem impedir a existência desse sistema. 
No campo processual penal, o registro criminal serve, essencialmente, como meio de prova para configurar a reincidência e os antecedentes criminais. Centralizá-lo em um serviço nacional único, conforme fazem os Estados unitários, possibilita emitir certificados por um só órgão e reduzir fraudes relativas ao acesso e ao fornecimento dos dados sem ampliar o risco da destruição por incidentes, porque ferramentas modernas na área da informática permitem copiar esses dados. Esse padrão, embora não aplicado ao modelo federativo, induz pensar que no Brasil os órgãos da Justiça e Polícia dos respectivos Estados membros, Distrito Federal e União deveriam conveniar-se e interligar, nacionalmente, o registro criminal.

O registro criminal deve ser concebido no Estado Democrático de Direito como mecanismo não-impeditivo para a construção de uma sociedade livre, justa e solidária sem revestir-se unicamente do indissociável caráter discriminatório. Para acompanhar o perfil democrático do Estado brasileiro, o registro criminal deveria ser estruturado a partir de orientação político-criminal fundada nos princípios constitucionais aplicáveis ao processo penal buscando, por exemplo, dotá-lo de mecanismos que estabeleçam "portas de entrada" e "vias de saída", ao evitar que anotação criminal antiga acompanhe a pessoa pela vida toda, cabendo fixar prazo a partir do qual o acesso seja restrito e a divulgação controlada.

O registro criminal não deve funcionar com a finalidade de exercer papel de moralização social ou servir como instrumento para reduzir a prática de crimes, especialmente porque esses efeitos poderão alcançar o criminoso ocasional, pessoa que normalmente teme a inscrição do seu nome nesse cadastro pela estigmatização e dificuldade para obter trabalho.

A tecnologia é essencial para o registro criminal estruturar-se e funcionar com modernismo, tendência que seguiu em determinados momentos da sua trajetória histórica, pois se não o fizesse acabaria obsoleto e incapaz de atender a demanda, observando que os avanços não poderão torná-lo frágil e permitir a exposição de informações sigilosas.

A regulação do acesso às informações do registro criminal não significa renúncia do Poder Público ao direito de conhecer os antecedentes criminais das pessoas envolvidas com a Justiça, mas demonstra o interesse de preservá-los da divulgação indevida. 
Do exame das questões referentes ao acesso do registro criminal insta apresentar as seguintes conclusões para o aperfeiçoamento (Capítulo 3):

O acesso irrestrito ao conteúdo das informações do registro criminal desvirtua sua finalidade que é oferecer informes à Justiça Criminal e o assemelha a uma espécie de punição autônoma e discriminatória para quem ostentar anotações.

Ao juiz, ao Ministério Público e à Polícia deve ser garantido amplo acesso ao registro criminal para o exercício específico das suas funções, enquanto ao acusado e seu defensor o acesso será concedido pelo juiz, se houver justa causa.

A divulgação da informação do registro criminal poderá ser restringida quando relacionada à prática de contravenção penal ou infração leve, seguindo-se a orientação fixada pelas Normas Gerais de Serviço da Corregedoria Geral da Justiça de São Paulo.

A previsão do artigo 225 , parágrafo $3^{\circ}$, da Constituição Federal, e a disposição contida na Lei $\mathrm{n}^{\circ}$ 9.605, de 1998, que permite punir pessoa jurídica autora de atividades lesivas ao meio ambiente, sugerem formar o cadastro criminal das pessoas jurídicas.

A legislação nacional deveria controlar o acesso de terceiros ao registro criminal, com normas claras, precisas e minuciosas para evitar divulgação indevida dos dados criminais, seja pela Administração Pública ou por terceiros.

A utilidade e a jovialidade do registro criminal decorrerão do equilíbrio entre a vedação da acessibilidade desmedida e a permissão para exteriorização do seu conteúdo atendendo o interesse público e particular justificados.

O agente que violar segredo protegido pelo sigilo do registro criminal será punido, tal qual aquele que negligenciar informações, cabendo em situações excepcionais facultar ao interessado o acesso direto aos dados desse sistema.

A doutrina portuguesa deveria orientar a legislação nacional quando aquela propõe cabível consultar os registros inacessíveis para instruir pedido de revisão da sentença condenatória e exames médicos e psicológicos tendentes à verificação da personalidade ou do estado mental do acusado ou para provar a inocência dele.

O sistema da cesura do julgamento caracterizado pela previsão da aferição da responsabilidade criminal antes da discussão sobre a fixação da pena não encontra campo fértil para sua incorporação ao processo criminal brasileiro por lentificar o 
julgamento sem impedir ao julgador o prévio conhecimento dos antecedentes do acusado, especialmente porque o modelo brasileiro vigente impõe à autoridade policial, desde o início da investigação, juntar ao inquérito policial a folha de antecedentes, tornando difícil efetivar alteração que impeça ao juiz conhecer os antecedentes criminais do investigado ou acusado, circunstâncias que sugerem mais efetividade da estruturação do sistema por meio da regulação do acesso e do cancelamento de determinadas anotações lançadas no registro a partir do decurso do tempo.

O interesse em ressocializar o condenado pode ultrapassar o término da pena se o registro criminal não impedir a reinserção social do ex-condenado, não servindo para a seleção das pessoas aptas para ocupar postos de trabalho, mas assegurando o conhecimento da existência de ordem de prisão não cumprida ou responsabilidade penal pendente.

Apesar de ser difícil regular por lei o acesso ao registro criminal, porque no Brasil é praxe o particular e a administração exigirem que o interessado apresente certidão de antecedentes criminais, essa regulação serviria para desestimular o particular não conceder vaga de trabalho a partir da avaliação negativa dos antecedentes do candidato e justificar a recusa por motivo diverso. Tal providência facilitaria discutir essa situação perante a Justiça, como se faz no caso de a administração discriminar pessoa para exercer ocupação comum na qual o interesse público dispensar prova dos antecedentes, especialmente se a exigência não constar da legislação, regulamento ou edital do concurso.

As informações fornecidas pelo registro criminal à Justiça e Polícia devem ser amplas, enquanto os dados concedidos aos órgãos administrativos, menos extensos e aqueles facultados aos particulares, mínimos e restritos ao essencial, devendo a legislação nacional inspirar-se no sistema francês que instituiu acesso escalonado aos informes providenciados pelos bulletins de casier judiciare, que alternam entre o grau máximo (um) até o mínimo (três) o conteúdo das informações divulgadas, atendendo o primeiro tipo de boletim resposta à Justiça, o tipo dois, aos órgãos administrativos e o tipo três, ao particular.

A idéia da justa causa é empregada pela legislação lusitana para fundamentar a emissão ou a recusa, integral ou parcial, da expedição de informações do registro criminal. No Brasil, essa aferição é feita pelo próprio juiz criminal, autoridade que avalia o cabimento do acesso, mesmo sem disposição legislativa. 
$\mathrm{O}$ acesso aos dados do registro criminal para fins estatísticos e de investigação científica deve ser amplo, porque não gera violação ao sigilo e servirá para fundamentar estudos doutrinários e propostas legislativas que permitirão aperfeiçoar o sistema.

Depois de analisar o funcionamento do registro criminal, o registro policial e outros temas correlatos, também cabe apresentar arremates significativos (Capítulo 4):

O registro policial deve estar separado do registro criminal e servirá como repositório cumulativo das informações criminais, por vezes útil para investigar crimes a partir dos antecedentes do suspeito. Não deveria fornecer atestados, mas caso necessário emiti-los será preciso preservar a privacidade da pessoa e respeitar o disposto no parágrafo único do artigo 20 do Código de Processo Penal. Restringir a divulgação do registro policial não reduz ou neutraliza sua importância, antes dificulta a terceiros, exceto se autorizados por lei, nele buscar informações que o registro criminal deveria ofertar. $\mathrm{O}$ respeito à privacidade do indivíduo e a eficiência esperada dos órgãos públicos, entre eles, da Polícia, correspondem às idéias do garantismo e da eficiência que devem nortear o registro policial.

$\mathrm{O}$ nome das pessoas procuradas pela Justiça deverá constar do registro criminal e policial, podendo permanecer disponível à população pelo interesse público em recapturar fugitivo, providência que a legislação processual penal permite seja realizada por qualquer pessoa independentemente de ordem judicial.

O Ministério Público deve ter acesso aos dados do registro criminal e policial para fins da promoção da ação penal, conforme previsão constitucional e legal, com idêntica amplitude permitida aos juízes e à Polícia. Se conveniente ao exercício das suas funções institucionais poderá criar e manter cadastro reservado contendo informações criminais das pessoas investigadas e acusadas a partir da análise dos inquéritos e processos, cadastro que servirá ao uso interno, mas excepcionalmente poderá ser utilizado para apontar antecedentes criminais se houver divergência, falha ou omissão do registro criminal.

O registro criminal e policial conterá anotações relativas à lavratura do termo circunstanciado, ao não-oferecimento da representação pela vítima quando necessário e à celebração de acordo civil tratados pela Lei $\mathrm{n}^{\circ}$ 9.099, de 1995, providência permitida pela aplicação subsidiária da regra do artigo 23 do Código de 
Processo Penal, conforme autoriza o artigo 92 da Lei nº 9.099, de 1995.

A aceitação da proposta de transação penal, que "não importará em reincidência" e "não constará de certidão de antecedentes criminais", será anotada automaticamente em campo próprio do registro criminal, porque, ao aceitá-la, o autor do fato ficará impedido de receber nova proposta por cinco anos, situação que deve ser conhecida pelo juiz e Ministério Público.

O disposto no artigo 84, parágrafo único, da Lei n 9.099 , de 1995, não viola a regra do automatismo do registro, pois a decisão condenatória que impõe o pagamento de multa exclusiva pela prática de infração penal de menor potencial ofensivo será inscrita no registro criminal com cláusula judicial geradora da restrição ao acesso depois da multa paga e extinta a punibilidade, providência que não apaga somente restringe a publicidade do registro.

A comprovação de que o acusado conheceu pessoalmente os dados do registro criminal e recebeu notícia da existência de determinado processo anteriormente ajuizado contra ele, cujo andamento foi suspenso em razão de não ter sido localizado e citado por edital sem comparecimento ao juízo ou nomeação de defensor, deveria ser enumerada pela legislação que trata da suspensão condicional do processo e do respectivo prazo prescricional (artigo 366 do Código de Processo Penal) como causa suficiente para permitir a retomada da tramitação processual, porquanto nessa situação o acusado recebeu notícia singela do processo, podendo avaliar a viabilidade de comunicar-se com o respectivo juízo e exercitar sua defesa.

A formação do rol de culpados é providência que a legislação ou a orientação fornecida pelos órgãos correicionais aos juízos criminais deveria suprimir, pois sua eliminação não ofende direito individual ou viola o devido processo penal, mas atualiza regra procedimental por ser demorado e ineficiente consultar informações relativas às decisões condenatórias proferidas por juízo criminal único compiladas em livro, classificadas a partir da colocação do nome dos condenados em ordem alfabética, se comparadas rapidez, certeza e abrangência das informações fornecidas pelo registro criminal.

A fotografia da pessoa deveria constar do registro criminal, por retratar-lhe caracteres pessoais úteis para dirimir certos casos de dúvida de identidade, providência fruto da mera transcrição da identificação criminal que abrange $o$ processo datiloscópico e fotográfico, nos exatos termos da Lei $\mathrm{n}^{\circ} 10.054$, de 7 de 
dezembro de 2000.

Ao fixar prazo de cinco anos para a sentença penal condenatória servir para forjar a reincidência, computado o período de prova da suspensão ou do livramento não revogados, o inciso I do artigo 64 do Código Penal sugere criar lei impeditiva do aproveitamento dessa condenação para fins de o juiz classificar o condenado portador de maus antecedentes criminais, se ultrapassado outro lapso temporal a ser definido pela legislação, providência que dificultaria o perene aproveitamento da informação do registro criminal pela aplicação do princípio da temporariedade ou transitoriedade.

A juntada de certidão judicial para provar reincidência e maus antecedentes é indispensável diante dos efeitos causados ao acusado, não se tratando essa exigência de medida que reduza a força probatória do conteúdo da folha de antecedentes, mas está orientada em matiz garantista e visa evitar que o juiz desconheça desfecho modificativo da decisão condenatória ainda não anotado na folha de antecedentes. O registro criminal não reúne anotação meritória e, portanto, não deveria manter anotação negativa se ela não conferir ao acusado a condição de reincidente ou de portador de maus antecedentes.

O direito ao silêncio deve ser assegurado plenamente ao acusado, inclusive na parte introdutória do interrogatório, também chamada primeira parte ou interrogatório de qualificação, fase em que o juiz lhe fará perguntas acerca da sua vida pregressa, se foi preso ou processado alguma vez, perante qual juízo, se o processo teve desfecho condenatório ou foi suspenso e se cumpriu a pena, assegurando legítima possibilidade de o acusado quedar-se silente se a resposta trouxer informação auto-incriminante ou lesiva à sua dignidade. Nessa situação, o silêncio do acusado não configurará qualquer crime, pois é inadmissível sua caracterização pelo exercício do direito de não se auto-incriminar mediante recusa de prestar colaboração para produção de prova que possa ser usada contra ele próprio.

Finalmente, a abordagem de vários assuntos relativos ao cancelamento do registro criminal conduz às ilações adiante apresentadas, que se mostram necessárias e importantes para sua melhor estruturação (Capítulo 5):

O cancelamento é espécie do gênero afastamento dos dados do registro que limita ou restringe a utilização desses dados, sem excluí-los do acervo, enquanto a 
eliminação permite separar e destruir o dado do registro, inviabilizando qualquer informação futura. A possibilidade de cancelar determinadas anotações do registro criminal demonstra seu efeito estigmatizante e beneficia aquele que o alcança, mostrando-se justificável sua regulação legal.

A anotação lançada no registro criminal não pode ser mantida exclusivamente por possuir valor histórico, argumento insuficiente para impedir o cancelamento. A importância histórica refere-se ao fato em si e não será alterada pelo cancelamento da anotação, providência que o órgão judiciário deve permitir, mediante exame individualizado do caso, se a anotação não servir para forjar reincidência ou maus antecedentes, prejudicar o conceito social da pessoa ou causar risco de ela sofrer, indevidamente, ofensa à privacidade ou medida restritiva da liberdade, justificativas que sobrepujam o interesse histórico.

A Lei 8.069 (Estatuto da Criança e do Adolescente), de 1990, ao permitir o cancelamento do registro de nascimento civil, vedar a expedição de certidão sobre o ato cancelado e sobre ele determinar sigilo afastável somente por ordem da autoridade judiciária para salvaguardar direitos, deveria orientar a regulação do cancelamento do registro criminal.

O transcurso do tempo e a comprovação de o requerente não estar sendo processado são requisitos objetivo e subjetivo que poderiam ser exigidos para justificar o cancelamento do registro criminal, com o fim de impedir a perenização da anotação, providência que submeteria o registro ao crivo do direito ao esquecimento e permitiria a conservação dos dados estritamente necessários para forjar reincidência e maus antecedentes.

O esquecimento relativo da condenação penal pode ser alcançado pela reabilitação, que gera sigilo sobre o processo e a condenação, exceto no caso de requisição judicial. A ampliação da reintegração social do condenado pela reabilitação criminal poderia ser alcançada pela concessão de efeito escalonado e em dois tempos. No primeiro, a anotação seria cancelada e no segundo, depois do transcurso de determinado prazo, seria eliminada, retornando o agente à condição de alguém que nunca cometeu crime. Não atende o princípio da proporcionalidade restringir a divulgação de decisão condenatória pela reabilitação criminal, sem facultar ao acusado absolvido, cuja punibilidade foi extinta ou sequer foi processado, usufruir mecanismo que gere efeito semelhante, pois no caso de sentença condenatória, cumprida ou extinta a pena, transcorrido lapso temporal determinado e cumpridas 
certas condições, é possível ao juiz decretar o sigilo do registro, efeito não previsto para as hipóteses indicadas, embora o acusado sequer tenha sido condenado.

O prazo a aguardar, antes do cancelamento da anotação do registro criminal relativa ao inquérito policial arquivado, deveria ser aquele que a lei penal impõe para operar o efeito da prescrição em relação ao crime investigado, considerando-se o patamar inferior da pena prevista pela lei, escolha guiada pelo princípio da proporcionalidade em sentido estrito e pela possibilidade de reduzir no tempo a estigmatização da pessoa humana.

A morte do interessado não deveria inviabilizar o ajuizamento de habeas data para conhecer e retificar dados inseridos no registro criminal do morto por seu cônjuge, ascendente, descendente ou irmão ou, pelo menos, não impedir sua substituição se a morte suceder ao pedido. A informação inserida no registro criminal, embora relacionada à vida privada, atinge a memória do morto e justifica essa providência, inspirada na revisão criminal tratada pelo artigo 623 do Código de Processo Penal, que permite o ajuizamento do pedido por terceiro, no caso da morte do condenado e sua continuidade, se morto o interessado durante a tramitação do pleito.

O registro criminal é arquivo de dados criminais mantido pelo Estado e dotado de fins públicos, cujo acesso é controlado e as suas informações protegidas pelo sigilo, tanto que é possível impetrar habeas data para discutir questões a ele relativas, medida que poderá ser ampliada se os juízes observarem a finalidade e o funcionamento desse sistema de dados criminais, limitando o uso dos seus informes para comprovar reincidência, maus antecedentes e atender outra finalidade legal.

A inclusão do nome de pessoa no registro criminal é freqüentemente determinada por juiz de direito, razão pela qual referida autoridade poderá ser considerada coatora se ajuizado mandado de segurança destinado a alterar o registro criminal.

Se a liberdade do requerente for restringida por ato da autoridade judicial decorrente de lançamento incorreto no registro criminal, será admissível a impetração do habeas corpus para assegurar a liberdade e corrigir o registro. Isso pode ocorrer pela utilização irregular dos dados de identificação pessoal, gerando indevida decretação da prisão preventiva ou anotação da existência de inquérito policial ou processo em relação ao inocente.

A descriminalização impede que a informação inserida no registro criminal seja divulgada para fins administrativo, particular e processual, porque isso poderia 
causar indevido rigor no tratamento e avaliação da pessoa. A informatização permitiria o cancelamento automático dos dados anotados no registro, mas a falta desse recurso não impede que a abolitio criminis justifique cancelar individualmente as anotações do registro. A comprovação da morte também permite cancelar o registro, embora não seja providência expressamente prevista pela lei, mas essa interpretação deverá ser extraída da qualificação da morte como causa extintiva da punibilidade, efeito previsto no artigo 107, inciso I, do Código Penal. Descriminalização e morte, em razão de produzirem efeitos extintivos da punibilidade, deveriam ser previstas, expressamente, pela legislação nacional como causas de eliminação da anotação do registro criminal, determinada pelo juiz ex officio ou para atender pedido feito pelo interessado, defesa, órgão do Ministério Público, cônjuge, ascendente, descendente ou irmão.

A idade avançada não é fundamento suficiente para gerar o cancelamento do registro criminal, pois é inadequado fixar idade limite para adoção dessa providência frente ao argumento da ampliação da longevidade do homem pela melhoria das condições de vida. A idade avançada e a presumível diminuição das energias não justificam o cancelamento do registro por não ser linear para todas as pessoas e concernentes a todos os crimes.

A suspensão condicional da pena impedirá o conhecimento das informações do registro criminal em relação aos particulares e a certas autoridades administrativas, devendo assegurar-se o fornecimento integral do informe para fins judiciais e policiais especialmente diante da provisoriedade dessa medida. A anotação do registro relativa a crime anistiado deveria ser cancelada para evitar efeito estigmatizante.

A informação cancelada do registro criminal não deve servir para provar reincidência ou antecedente desabonador, mesmo confirmada por outro meio de prova, situação em que a não-admissão dessa prova se equipara a dados da ciência particular do juiz, os quais não serão utilizados para fins probatórios. Nos crimes dolosos contra a vida, a legislação processual penal deveria vedar o debate em plenário sobre o conteúdo do registro criminal do réu, impedindo acusação e defesa discutirem antecedentes criminais para prejudicar ou beneficiar o acusado e evitando o julgamento por fato diverso daquele tratado no processo. 


\section{RESUMO}

Esta tese denominada "Registro Criminal. Análise e proposta para sua estruturação no processo penal sob o enfoque da eficiência e do garantismo" aponta relacionamentos de temas processuais penais e constitucionais com o registro criminal como segurança e liberdade, princípio da proporcionalidade, eficiência e garantismo, vida privada e sigilo, contraditório e presunção de inocência. Em seguida, estuda conceito, finalidade, natureza, conteúdo, centralização e principais características do registro criminal, examinando também política criminal e tecnologia estritamente ligadas ao tema.

O estudo analisa origens próxima e remota do registro criminal; aborda especialmente sua regulação em Portugal, Itália, França e Espanha; destaca sua trajetória histórica no Brasil; trata do acesso às informações contidas no registro criminal; demonstra ser necessário equilibrar a divulgação dos dados criminais frente à finalidade pretendida pelo órgão ou pessoa que os busca; e examina a justa causa e o acesso legal para fins diversos.

Depois de tratar do funcionamento do registro criminal brasileiro, o estudo discorre sobre as características gerais do registro policial. A seguir refere a possibilidade de o Ministério Público criar cadastro criminal e aborda aspectos processuais penais de temas especialmente ligados ao registro criminal como anotação da infração de menor potencial ofensivo, suspensão processual, rol de culpados, folha de antecedentes, reincidência, antecedentes, interrogatório e execução penal.

O texto é robustecido pelo debate concernente ao cancelamento e à eliminação dos dados do registro criminal a partir do transcurso do tempo. Prossegue estudando assuntos estruturados em campos diversos do conhecimento jurídico que geram reflexos aos domínios do registro criminal como ocorre com os temas reabilitação, habeas data, mandado de segurança e habeas corpus, além de abordar descriminalização, idade, morte, pena suspensa, anistia, cancelamento e exclusão da prova.

A tese é concluída com a síntese das idéias debatidas que poderão fundamentar propostas de alteração legislativa e proporcionar mudanças nos paradigmas seguidos para tratar o registro criminal brasileiro a começar da sua relativa (des)estruturação e do intenso efeito por ele causado na vida da pessoa submetida à investigação ou a processos criminais. 


\section{RIASSUNTO}

Questa tesi, denominata "Casellario giudiziale. Analisi e proposta per il suo assetto nel processo penale dal punto di vista dell'efficienza e del garantismo", indica i rapporti di temi processuali penali e costituzionali con il casellario giudiziale, quali la sicurezza e la libertà, il principio di proporzionalità, efficienza e garantismo, vita privata e segreto, contraddittorio e presunzione d'innocenza. In seguito studia concetto, finalità, natura, contenuto, centralizzazione e le principali caratteristiche del casellario giudiziale, esaminando pure politiche criminali e tecnologie strettamente connesse al tema.

Lo studio analizza la genesi recente e remota del casellario giudiziale; abborda specificamente la sua regolazione in Portogallo, Italia, Francia e Spagna; mette in risalto la sua traiettoria storica in Brasile; tratta dell'accesso alle informazioni contenute nel casellario giudiziale; dimostra che è necessario equilibrare la divulgazione dei dati penali di fronte alla finalità pretesa dall'organo o persona che li ricerca ed esamina la giusta causa e 1'accesso legale per fini diversi.

Dopo aver trattato del funzionamento del casellario giudiziale brasiliano, lo studio disserta sulle caratteristiche generali del registro di polizia. In seguito indica la possibilità che il Pubblico Ministero crei um registro penale e aborda aspetti processuali penali di temi specificamente legati al casellario giudiziale come ad esempio l'annotazione di infrazione di modesto potenziale offensivo, la sospensione processuale, il registro dei colpevoli, il foglio dei precedenti, la recidiva, i precedenti, l'interrogatorio e l'esecuzione penale.

Il texto si alimenta anche del dibattito concernente la cancellazione o l'eliminazione dei dati del casellario giudiziale com il decorrere del tempo. Prosegue studiando argomenti che abbracciano campi diversi della conoscenza giuridica che generano effetti riflessi sui dominii dl casellario giudiziale, come si verifica con i temi della riabilitazione, habeas data, "mandado de segurança" [ricorso avverso la violazione della legge o l'abuso o eccesso di potere della pubblica amministrazione o del giudice] e "habeas corpus" [equivalente al ricorso al Tribunale della libertà in Italia], oltre ad abbordare depenalizzazione, età, morte, sospensione della pena, amnistia, cancellazione e esclusione della prova.

La tesi si conclude com la sintesi delle idee in dibattito che potranno supportare proposte di alterazione legislativa e addurre cambiamenti nei paradigmi osservati nel trattare il casellario giudiziale brasiliano, a cominciare dalla sua (disi)strutturazione e 
dall'intenso effetto da esso causato nella vita della persona sottoposta ad indagine o a processo penale. 


\section{RÉSUMÉ}

Cette thèse dénommée: "Casier judiciare. Analyse et proposition pour sa structuration dans le processus penal sous le thème de l'éfficience et de la garantie", pointe les relations des textes processuels et constitutionnels avec le casier judiciare comme sécurité et liberté, principe de la proportion, de l'efficience et de la garantie, vie privée et secrète, contradictoire et présomption de l'innocence. Pour ce faire, étudie le concept, la finalité et la nature, le contenu, centralisation et les caractéristiques principales du casier judiciare, examinant aussi la politique criminelle et la technologie strictement liée au thème.

L'étude analyse les origines proches et distantes du casier judiciare, aborde spécialement sa régulation au Portugal, en Italie, en France et en Espagne, met en évidence sa trajectoire historique au Brésil, il s'agit de l'accès aux informations contenues dans le casier judiciare, se montre être nécessaire pour équilibrer la divulgation des données criminaux devant la finalité prétendue par l'organisme où la personne qui est à la recherche et examine la juste cause et l'accès légal pour plusieurs finalités.

Après avoir traîté du fonctionnement du casier judiciare brésilien, l'étude discourt sur les caractéristiques générales du registre policier. À suivre se refère à la possibilité du Ministère Publique pour créer un cadastre criminel et aborde des aspects processuels penaux des thèmes spécialement liés au casier judiciare comme annotation de l'infraction du potentiel inférieur, offensif, suspension processuelle, rôle des coupables, feuille des antécédents, réincidence, antécédents, interrogatoire et l'exécution penal.

Le texte est résistant pour le débat concernant à l'annulation et à l'élimination des données du casier judiciare à partir du transcours du temps. Poursuit à étudier les sujets structurés dans les divers champs de la connaissance juridique qui gèrent des reflets aux domaines du casier judiciare comme ont lieu avec les thèmes réhabilitation, habeas data, mandat de sécurité et habeas corpus, apart d'aborder la descriminalisation, âge, mort, peine suspendue, anistie, annulation et exclusion de la preuve.

La thèse est conclut avec la synthèse des idées débatues qui pourront fonder des propositions de l'altération legislative et proportionner des changements dans les paradigmes pour traiter du casier judiciare brésilien à commencer de sa relative (des) structuration et de l'intense effet par lui dans la vie de la personne soumise à l'investigation où aux processus criminaux. 


\section{BIBLIOGRAFIA}

ALGRANTI, Leila Mezan. Os registros da polícia e seu aproveitamento para a história do Rio de Janeiro: escravos e libertos. Revista de História. São Paulo, USP, n. 119 (nova série), p. 115-125, jul. 1985/dez. 1988.

ALMEIDA, Fernando H. Mendes de. Ordenações Filipinas. Ordenações e leis do Reino de Portugal recopiladas por mandado d'el Rei D. Felipe, o Primeiro. São Paulo: Saraiva, 1957. v. 1.

ALMEIDA, Joaquim Canuto Mendes de. Princípios fundamentais do processo penal. São Paulo: RT, 1973.

ALMEIDA JÚNIOR, João Mendes. O processo criminal brasileiro. 4. ed. Rio de Janeiro e São Paulo: Freitas Bastos, 1959. v. I e II.

ARAGÃO, E. D. Moniz. Estatística judiciária. Revista Forense, Rio de Janeiro: Forense, v. 365, p. 7-15, fev. 2003.

ARAS, Vladimir. Princípios do processo penal. Disponível em: $<$ http://mundojuridico.adv.br/cgi-bin/upload/texto115(3).rtf>. Acesso em: 12 set. 2008.

ARAÚJO, José Laércio. Intimidade, vida privada e direito penal. São Paulo: Habeas [s.d.]. p. $119-121$.

ARGENTINA. L. 22117 - Registro Nacional de Reincidencia. Disponível em: $<$ http://consulex.com.ar/Legislacion/Leyes/L0022117.htm>. Acesso em: 3 jan. 2008. 
ASSOCIAÇÃO PARA O DESENVOLVIMENTO DO TELETRABALHO. Convenção $\mathrm{n}^{\mathrm{o}} 108$ do Conselho da Europa. Disponível em: $<$ http://www.apdt.org/guia/L/Ldados/108.htm>. Acesso em: 19 nov. 2007.

ATO No 168/98-PGJ-CGMP, de 21 de dezembro de 1998. Publicações Eletrônicas Associação Paulista do Ministério Público. São Paulo: APMP, 2004-2006. 1 CD-ROM. Produzido por Eduardo Roberto Alcântara Del-Campo e Marinilce Araújo Soria.

BARRÉ, Marie-Daniéle; POTTIER, Marie-Lys. Interpellés hier, aujourd'hui et demain. Analyse des séquences de mises en cause dans procedúres de police judiciaire. Déviance et Société, v. 27, n. 2, p. 131-159, 2003.

BATISTA, Nilo. Introdução crítica ao direito penal brasileiro. 8. ed. Rio de Janeiro: Revan, 2002.

BATTAGLIA, Elisa; FEDERICO, Giacomo di. La carta dei diritti e la tutela della riservatezza. In: ROSSI, Lucia Sereno (Coord.). Carta del diritti fondamentali e costituzione dell'Unione Europea. Milano: Giuffré, 2002.

BISSOLI FILHO, Francisco. Estigmas da criminalização: dos antecedentes à reincidência criminal. Obra Jurídica: Florianópolis, 1998.

BITENCOURT, Cezar Roberto. Manual de direito penal: parte geral. 4. ed. São Paulo: RT, 1997.

; PRADO, Luiz Regis. Código Penal anotado e legislação complementar. São Paulo: RT, 1997.

BORBA, Francisco S. Dicionário de usos do português no Brasil. São Paulo: Ática, 2002. 
BRASIL. Superior Tribunal de Justiça. Agravo Regimental no Recurso Especial no 753.419, Relatora: Ministra: Jane Silva, Brasília, DF. Diário Oficial [da] República Federativa do Brasil, Brasília, DF, 26 maio 2008, ed. 146, doc. 3878407.

BRASIL. Superior Tribunal de Justiça. Habeas Corpus $\mathrm{n}^{\mathrm{o}}$ 14.376/SP, Relator: Ministro José Arnaldo da Fonseca, da $5^{\text {a }}$ Turma, Brasília, DF, 2 de março de 2004. Diário Oficial [da] República Federativa do Brasil, Brasília, DF, 29 mar. 2004. p. 254.

BRASIL. Superior Tribunal de Justiça. Habeas Corpus nº 47.774/MS, Relatora: Ministra Maria Thereza de Assis Moura, da $6^{\mathrm{a}}$ Turma, Brasília, DF, 30 de outubro de 2007. Diário Oficial [da] República Federativa do Brasil, Brasília, DF, 26 nov. 2007. p. 248-249.

BRASIL. Superior Tribunal de Justiça. Recurso Especial no 254.005 -DF, Relator: Ministro José Arnaldo da Fonseca, da $5^{\text {a }}$ Turma, Brasília, DF, 19 de março de 2002. Diário Oficial [da] República Federativa do Brasil, Brasília, DF, 6 maio 2002.

BRASIL. Superior Tribunal de Justiça. Recurso Especial n 275.971-DF, Relator: Ministro Gilson Dipp, da 5 $5^{\text {a }}$ Turma, Brasília, DF, 24 de setembro de 2002. Diário Oficial [da] República Federativa do Brasil, Brasília, DF, 11 nov. 2002.

BRASIL. Superior Tribunal de Justiça. Recurso Especial $\mathrm{n}^{\mathrm{o}}$ 285.750-DF, Relatora: Ministra Laurita Vaz, da $5^{\text {a }}$ Turma, Brasília, DF, 19 de agosto de 2003. Diário Oficial [da] República Federativa do Brasil, Brasília, DF, 8 mar. 2004.

BRASIL. Superior Tribunal de Justiça. Recurso Especial n ${ }^{\circ}$ 286.419/SP, Relatora: Ministra Maria Thereza de Assis Moura, da $6^{\text {a }}$ Turma, Brasília, DF, 24 de maio de 2007. Lex STJ, São Paulo, v. 216, p. 337, ago. 2007. 
BRASIL. Superior Tribunal de Justiça. Recurso Ordinário em Habeas Corpus n $\mathrm{n}^{\circ}$ 8.575/SP, Relator: Ministro Fernando Gonçalves, da 6a Turma, Brasília, DF, 21 de junho de 1999. Publicações Eletrônicas Associação Paulista do Ministério Público. São Paulo: APMP, 2004-2006. 1 CD-ROM. Produzido por Eduardo Roberto Alcântara Del-Campo e Marinilce Araújo Soria.

BRASIL. Superior Tribunal de Justiça. Recurso Ordinário em Mandado de Segurança $\mathrm{n}^{\mathrm{o}}$ 6.761/SP, Relator: Ministro Luiz Vicente Cernicchiaro, da $6^{\mathrm{a}}$ Turma, Brasília, DF, 10 de junho de 1996. Lex STJ, São Paulo, v. 92, p. 338-342, abr. 1997.

BRASIL. Superior Tribunal de Justiça. Recurso Ordinário em Mandado de Segurança $\mathrm{n}^{\mathrm{o}}$ 7.220/SP, Relator: Edson Vidigal, da 5 Turma, Brasília, DF, 23 de setembro de 1996. Disponível em: <http://www.stj.jus.br/webstj/Processo/stjimagem/frame.asp?browser+true? vPortalAreaPai+289\&vPortalArea+338\&vPortalAreaRaiz+>. Acesso em: 20 set. 2008.

BRASIL. Superior Tribunal de Justiça. Recurso Ordinário em Mandado de Segurança $\mathrm{n}^{\circ}$ 9.879/SP, Relator: Ministro Gilson Dipp, da 5 $5^{\mathrm{a}}$ Turma, Brasília, DF, 9 de abril de 2002. Diário Oficial [da] República Federativa do Brasil, Brasília, DF, 3 jun. 2002. p. 214.

BRASIL. Superior Tribunal de Justiça. Recurso Ordinário em Mandado de Segurança $\mathrm{n}^{\mathrm{o}}$ 16.202/SP, Relator: Ministro Felix Fischer, da $5^{\mathrm{a}}$ Turma, Brasília, DF, 17 de junho de 2003. Diário Oficial [da] República Federativa do Brasil, Brasília, DF, 12 ago. 2003. p. 246.

BRASIL. Supremo Tribunal Federal. Habeas Corpus $n^{0}$ 68.569/DF, Relator: Ministro Celio Borja, da 2a Turma, Brasília, DF, 11 de junho de 1991. Diário Oficial [da] República Federativa do Brasil, Brasília, DF, 16 ago. 1991. p. 10786.

BRASIL. Tribunal de Alçada. Apelação Criminal $n^{\circ}$ 2.125, Relator: Vicente Borges, da $1^{\text {a }}$ Turma da Câmara, Carmo do Cajuru, MG, 3 de setembro de 1971. RT, São Paulo, v. 440, p. 459-460, jun. 1972. 
BRASIL. Tribunal de Alçada. Apelação Criminal n 188.816-3, Relator: Djalma Lofrano, da 6ª̂mara Criminal, Campinas, SP, 14 de setembro de 1995. Diário Oficial do Estado de São Paulo, Poder Judiciário, São Paulo, SP, 10 out. 1995. Caderno I.

BRASIL. Tribunal de Alçada. Apelação $n^{\circ}$ 290099860, Relator: Luiz Gonzaga Pila Hofmeister, da $1^{\text {a }}$ Câmara Criminal, Rio Grande do Sul, RS, 10 de outubro de 1990. Revista dos Tribunais, São Paulo, ano 80, v. 665, p. 329-330, mar. 1991.

BRASIL. Tribunal de Alçada Criminal. Mandado de Segurança $n^{\circ}$ 398.542-8/Jundiaí, Relator: Carlos Biasotti, da 15ª Câmara, São Paulo, SP, 7 de março de 2002. Revista dos Juizados Especiais, São Paulo, ano 7, v. 23, p. 207-211, jan./mar. 2002.

BRASIL. Tribunal de Alçada Criminal. Processo $n^{0}$ 36.715, Relator: Francis Davis, da $4^{\mathrm{a}}$ Câmara, São Paulo, SP, 18 de maio de 1972. Por maioria de votos. Revista dos Tribunais, São Paulo, n. 448, p. 389, fev. 1973.

BRASIL. Tribunal de Justiça. Habeas Corpus $\mathrm{n}^{\mathrm{o}}$ 462.544-3/3-00, Relator: Ricardo Tucunduva, da $6^{\text {a }}$ Câmara Criminal, São Paulo, SP, 12 de agosto de 2004. Por unanimidade de votos. Jurisprudência do Tribunal de Justiça, São Paulo, v. 283, p. 539-541, dez. 2004.

BRASIL. Tribunal de Justiça. Habeas Data $\mathrm{n}^{\mathrm{o}}$ 1/90, Relator: Des. Mauro José Pereira, Mato Grosso, MS, 8 de março de 1990. Revista dos Tribunais, n. 668, p. 138, jun. 1991.

BRASIL. Tribunal de Justiça. Mandado de Segurança $n^{\circ}$ 397.319-3/9, Relator: Damião Cogan, da $5^{\text {a }}$ Câmara Criminal, São Paulo, SP, 6 de fevereiro de 2003. Jurisprudência do Tribunal de Justiça, São Paulo, v. 267, p. 597-602, ago. 2003.

BRASIL. Tribunal de Justiça. Mandado de Segurança n 416.545-3/6-00, Relator: Almeida Braga, da $2^{\text {a }}$ Câmara Criminal, São Paulo, SP, 26 de maio de 2003. Jurisprudência do Tribunal de Justiça, São Paulo, v. 268, p. 592-598, set. 2003. 
BRASIL. Tribunal de Justiça. Mandado de Segurança $n^{\circ}$ 438.372.3/7, Relator: Hélio de Freitas, da 4ª Câmara Criminal, São Paulo, SP, 30 de março de 2004. Disponível em: $<$ http://cjo.tj.sp.gov.br/esaj/cpo/sg/show.do?processo.foro $+990 \&$ processo.codigo $=$ RL00C QYF0000\&cdForo=1\&baseIndice=INDSG>. Acesso em: 20 set. 2008.

BRASIL. Tribunal de Justiça. Mandado de Segurança n ${ }^{\circ}$ 440.517-3/0-00, Relator: Damião

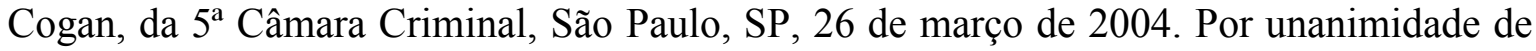
votos. Jurisprudência do Tribunal de Justiça, São Paulo, v. 279, p. 653-658, ago. 2004.

BRASIL. Tribunal Regional Federal - $1^{\mathrm{a}}$ Região. Recurso Ex Officio n $^{\mathrm{o}}$ 94.01.34562-7, Relator: Des. Federal Eustáquio Silveira, da 4ª Turma, Brasília, DF, 29 de março de 1995. Diário Oficial [da] República Federativa do Brasil, Brasília, DF, 27 abr. 1995. p. 24659.

BRASIL. Tribunal Regional Federal - 2a Região. Apelação Criminal no 94.02.21346-5/RJ, Relator: Des. Federal Arnaldo Lima, da $3^{\text {a }}$ Turma. Rio de Janeiro, RJ, 7 de fevereiro de 1996. RT, São Paulo, v. 736, p. 715-721, fev. 1997.

BRITO, Aléxis Augusto Couto de. Execução penal. São Paulo: Quartier Latin, 2006.

BUENO, José Antonio Pimenta (Marquez de S. Vicente). Apontamentos sobre o processo criminal brasileiro. 4. ed. annotada pelo Dr. Vicente Ferrer de Barros W. Araújo. Lisboa: Livraria Clássica Editora de A. M. Teixeira \& C., 1910.

BUENO ARÚS, Francisco. La cancelación de antecedentes penales. Barcelona: Thomson Civitas, 2006.

CAMARGO, Antonio Luis Chaves. Sistemas de penas, dogmática jurídico-penal e política criminal. São Paulo: Cultural Paulista, 2002.

CANCELAR. In: Dicionário Michaelis da língua portuguesa. Disponível em: 
$<$ http://michaelis.uol.com.br/moderno/portugues/index.php?lingua=portuguesportugues\&palavra=cancelar>. Acesso em: 22 set. 2008.

CAPEZ, Fernando. Curso de direito penal: parte geral. 11. ed. São Paulo: Saraiva, 2007. v. 1 .

CARVALHO, Pedro Armando Egydio. Estar-lá, longe: o leproso de hoje mas quem é o meu próximo? (LC 10:29). São Paulo, Boletim IBCCrim, n. 123, p. 16-17, set. 2003.

CASTRO, Catarina Sarmento e. Protecção de dados pessoais na Internet. Sub judice Justiça e Sociedade. Coimbra: Almedina, n. 35, p. 11, set. 2006.

CASTRO, Ruy. Revista Imprensa, Imprensa Editorial, São Paulo, ano 20, n. 226, p. 19, ago. 2007. Entrevista concedida ao Repórter Pedro Venceslau.

CERNICCHIARO, Luiz Vicente. Sentença - Não faz sentido os arquivos judiciários ficarem escancarados, por tempo indeterminado. Disponível em: $<$ http://cristianemarinhopenal.vilabol.uol.com.br/t4.htm>. Acesso em: 9 mar. 2005.

CESTARO, Marcel Del Bianco. A inconstitucionalidade dos efeitos (muitas vezes) perenes resultantes de um processo criminal. São Paulo, Boletim IBCCrim, n. 181, p. 6-8, dez. 2007.

CHOUKR, Fauzi Hassan. Comentários sobre o projeto de investigação criminal. São Paulo, Revista dos Tribunais, n. 789, p. 457-481, jul. 2001.

CINTRA, Antonio Carlos de Araújo; GRINOVER, Ada Pellegrini; DINAMARCO, Cândido Rangel. Teoria geral do processo. 13. ed. São Paulo: Malheiros, 1997.

CLÉVE, Clémerson Merlin. Habeas data: algumas notas de leitura. In: WAMBIER, 
Teresa Arruda Alvim (Coord.). Habeas data. São Paulo: RT, 1998. p. 74-77.

COSTA, António Manuel de Almeida. O registo criminal. Coimbra: Gráfica de Coimbra, 1985.

COSTA FILHO, Luiz Manoel. Folha Corrida sem nota de culpa para os condenados beneficiados com o "sursis". Revista Brasileira de Direito Processual, v. 13, 89-108, jan./mar. 1978.

CRIMINAL.

$<$ http://michaelis.uol.com.br/moderno/portugues/index.php?lingua=portuguesportugues\&p alavra $=$ criminal $>$. Acesso em: 4 nov. 2007.

DECRETO FEDERAL N ${ }^{\circ}$ 6.138, de 28 de junho de 2007. Publicações Eletrônicas Associação Paulista do Ministério Público. São Paulo: APMP, 2004-2006. 1 CD-ROM. Produzido por Eduardo Roberto Alcântara Del-Campo e Marinilce Araújo Soria.

DELMANTO, Celso. Código Penal comentado. 3. ed. Rio de Janeiro: Renovar, 1991.

DELMANTO JÚNIOR, Roberto. As modalidades de prisão provisória e seu prazo de duração. Rio de Janeiro: Renovar, 1998.

DEPARTAMENTO DE POLÍCIA FEDERAL. Disponível em: $<$ http://www.dpf.gov.br/homepageIni.html>. Acesso em: 24 novembro 2007.

DIAS, Jorge de Figueiredo. Direito penal português. Parte geral. Lisboa: Aequitas, 1993. v. II.

DINAMARCO, Cândido Rangel; CINTRA, Antonio Carlos de Araújo e GRINOVER, Ada Pellegrini e. Teoria Geral do Processo. 13. ed. São Paulo: Malheiros, 1997.

DOTTI, René Ariel. Curso de direito penal: parte geral. Rio de Janeiro: Forense, 2005. 
$\mathrm{O}$ direito ao esquecimento e a proteção ao habeas data. In: WAMBIER, Teresa Arruda Alvim (Coord.). Habeas data. São Paulo: RT, 1998. p. 300.

ESPÍNOLA FILHO, Eduardo. Código de Processo Penal brasileiro anotado. 6. ed. Rio de Janeiro: Borsoi, 1965. v. I, VII, VIII e IX.

FALCONI, Romeu. A questão dos antecedentes criminais. São Paulo, Revista da Faculdade de Direito das Faculdades Metropolitanas Unidas, v. 5, p. 189-219, set. 1991.

FARIA, Antonio Bento de. Código de Processo Penal. 2. ed. Rio de Janeiro: Record, 1960. v. III.

FERENCZI, Thomas. Faut-il un casier judiciare européen. Le Monde, Paris, 1 fév. 2005. Disponível em: $\quad<$ http://www.france3europe.com/archive/2005/02/01/fautil_un_casier_judiciare_europe.htm>. Acesso em: 11 jun. 2005.

FERNANDES, Antonio Scarance. Processo penal constitucional. 3. ed. São Paulo: RT, 2002.

; GRINOVER, Ada Pellegrini; GOMES FILHO, Antonio Magalhães. As nulidades no processo penal. 8. ed. São Paulo: RT, 2004.

; Redução da idade para a responsabilização penal. Disponível em: <www.ibccrim.org.br >. Acesso em: $31 \mathrm{dez} 2004$.

Procedimento no processo penal: noções, perspectivas simplificadoras e rumos no direito brasileiro. São Paulo: RT, 2005.

. A reação defensiva à imputação. São Paulo: RT, 2002. 
Reflexões sobre as noções de eficiência e de garantismo no processo penal. In: ALMEIDA, José Raul Gavião de; MORAES, Maurício Zanoide de (Coord.). Sigilo no processo penal. Eficiência e garantismo. São Paulo: RT, 2008. p. 9-28.

FERRAZ JÚNIOR, Tércio Sampaio. Sigilo de dados: o direito à privacidade e os limites à função fiscalizadora do Estado. Sigilo fiscal e bancário. In: COSTA, José de Faria; SILVA, Marco Antonio Marques da. Direito penal especial, processo penal e direitos fundamentais: visão luso-brasileira. São Paulo: Quartier Latin, 2006.

FERREIRA, Aurélio Buarque de Holanda. Dicionário eletrônico Aurélio - Século XXI. Rio de Janeiro: MGB Informática, 1999. 1 CD-ROM. Produzido por Lexikon Informática.

FOLHA ONLINE. REUTERS. Estudante plantou bomba em shopping da Finlândia, diz polícia. Disponível em: 〈http://tools.folha.com.br/print?skin=emcimadahora\&url=http\%3A\%fowww1.folha>. Acesso em 10 set. 2005.

FOUCAULT, Michel. Vigiar e punir. 32. ed. Tradução de Raquel Ramalhete. Petrópolis: Vozes, 1987.

FRANÇA. Ministère de la Justice. Le Casier judiciaire national. Les extraits des casiers des personnes physiques et morales. Disponível em: $<$ http://www.justice.gouv.fr/cjn/extraits.htm>. Acesso em: 11 de junho de 2005.

FRANCESCO, Carnelutti. Misérias do processo penal. Trad. José Antonio Cardinalli. Campinas: Conan, 1995.

FRANCO, Alberto Silva et al. Teoria e prática do júri. 6. ed. São Paulo: RT, 1997. ; STOCO, Rui (Coord.). Código de Processo Penal e sua interpretação jurisprudencial. São Paulo: RT, 1999. v. 1 e 2. 
GARCIA, Maria. Habeas data: o direito à informação. In: WAMBIER, Teresa Arruda Alvim (Coord.). Habeas data. São Paulo: RT, 1998. p. 230-231.

GASPAR, António Henriques. Os novos desafios do processo penal no século XXI e os direitos fundamentais (um difícil equilíbrio). Revista Portuguesa de Ciência Criminal. Coimbra, ano 15, n. 2, p. 257-275, abr./jun. 2005.

GOMES FILHO, Antonio Magalhães. Presunção de inocência e prisão cautelar. São Paulo: Saraiva, 1991.

Direito à prova no processo penal. São Paulo: RT, 1997.

. A motivação das decisões penais. São Paulo: RT, 2001. p. 165.

; FERNANDES, Antonio Scarance; GRINOVER, Ada Pellegrini; As nulidades no processo penal. 8. ed. São Paulo: RT, 2004.

GONZÁLEZ YÁNEZ, Claudio; POMPILIO TEJERA, Alicia. Eliminación de anotaciones prontuariales y bancos de datos de organismos policiales. Revista de Estudios y Penitenciarios, Chile, v. 4, p. 131-144, mayo 2003.

GRACIA MARTÍN; Luis; BOLDOVA PASAMAR, Miguel Ángel; ALASTUEY DOBÓN, M. Carmen. Las consecuencias jurídicas del delito en el nuevo Código Penal español. Valencia: Tiran lo Blanch, 1996.

GRECO FILHO, Vicente. Manual de processo penal. 6. ed. São Paulo: Saraiva, 1999.

GRINOVER, Ada Pellegrini. Liberdades públicas e processo penal. 2. ed. São Paulo: RT, 1982. 
. Lineamentos gerais para o novo processo penal na América Latina; Argentina, Brasil e o Código Modelo para Ibero-América. Revista de Processo, São Paulo, v. 15, n. 58, p. 121-134, abr.jun. 1990.

O interrogatório como meio de defesa (Lei 10.792/2003). Revista Brasileira de Ciências Criminais, RT, São Paulo, n. 53, p. 188, mar./abr. 2005.

; MOREIRA, José Carlos Barbosa (Colab.). Projeto de Código Processual Penal-Tipo para a Ibero-América. $2^{\text {a }}$ Parte. Revista de Processo, São Paulo, n. 62, p. 176, jan./set. 1991.

; DINAMARCO, Cândido Rangel; CINTRA, Antonio Carlos de Araújo. Teoria geral do processo. 13. ed. São Paulo: Malheiros, 1997.

.Juizados Especiais Criminais. 4. ed. São Paulo: RT, 2002.

; FERNANDES, Antonio Scarance; GOMES FILHO, Antonio Magalhães. As nulidades no processo penal. 8. ed. São Paulo: RT, 2004.

GROSSO GALVAN, Manuel. Los antecedentes penales: rehabilitación y control social. Barcelona: Bosch, 1983.

ITALIA. Codice di Procedura Penale. Disponível em: $<$ http://www.altalex.com/index.php?idnot=36786>. Acesso em: 3 jan. 2008.

JESUS, Damásio Evangelista de. Código Penal anotado. 7. ed. São Paulo: Saraiva, 1997.

LEI ORGÂNICA DO MINISTÉRIO PÚBLICO DO ESTADO DE SÃO PAULO, Lei Complementar no 734, de 26 de novembro de 1993. Publicações Eletrônicas Associação 
Paulista do Ministério Público. São Paulo: APMP, 2004-2006. 1 CD-ROM. Produzido por Eduardo Roberto Alcântara Del-Campo e Marinilce Araújo Soria.

LEITE FILHO, Nelson. Antecedentes criminais. Revista dos Tribunais, São Paulo, n. 778, p. 489-492, ago. 2000.

LOPES, Maurício Antonio Ribeiro; LOPES, Vera Maria de Oliveira Nusdeo. Ementário sobre o habeas data. In: WAMBIER, Teresa Arruda Alvim (Coord.). Habeas data. São Paulo: RT, 1998. p. 437.

LOPES, Vera Maria de Oliveira Nusdeo; LOPES, Maurício Antonio Ribeiro. Ementário sobre o habeas data. In: WAMBIER, Teresa Arruda Alvim (Coord.). Habeas data. São Paulo: RT, 1998. p. 437.

MACHADO, Daniel Felipe. Registro Criminal e o Juizado Especial. Revista dos Juizados Especiais, Brasília, Tribunal de Justiça do Distrito Federal e dos Territórios, n. VIII, p. 18, jan./jun. 2000.

MAIER, Julio B. J. La cesura del Juicio Penal. Doctrina penal. Teoría y práctica en las ciencias penales. Depalma, Buenos Aires, ano 7, n. 26, p. 263, 1984.

MANZINI, Vicenzo. Trattato di diritto penale italiano. 4. ed. Torino: Torinese, 1961. v. 3.

MARQUES, José Frederico. Elementos de direito processual penal. Campinas: Bookseller, 1997. v. II, III e IV.

MEDIDA CAUTELAR $\quad \mathrm{N}^{\mathrm{o}}$ 130/07. Disponível em: http://www.stf.jus.br/portal/jurisprudencia/listarJurisprudencia.asp?s1=medida $\% 20 \mathrm{e} \% 2013$ 0\%20e\%202007\&base=baseAcordaos. Acesso em: 13 dezembro de 2008. 
MEIRELES, Andrei; JÚNIOR, Carlos Alberto. Opinião Suprema. Revista Época, São Paulo, n. 211, p. 13-17, 3 jun. 2002.

MEIRELLES, Hely Lopes. Mandado de segurança, ação popular e ação civil pública. 11. ed. São Paulo: RT, 1987.

MENDES, Clóvis. A possibilidade de exclusão de inquéritos e processos dos registros de $\begin{array}{llll}\text { instituto de } & \text { identificação. } & \text { Disponível em }\end{array}$ $<$ http://www.ibcrim.org.br/site/artigos/_imprime.php?jur_id=8734>. Acesso em: 14 jul. 2007.

MIRABETE, Julio Fabbrini. Manual de direito penal. 12. ed. São Paulo: Atlas, 1997. v. 1. Processo penal. São Paulo: Atlas, 2001.

Execução penal: comentários à Lei 7.210, de 11-7-1984. 10. ed. São Paulo: Atlas, 2002.

MIR PUIG, Santiago. Derecho penal: parte general. 4. ed. Barcelona: PPU, 1996.

MORAES, Maurício Zanoide; MOURA, Maria Thereza Rocha de Assis. Direito ao silêncio no interrogatório. Revista Brasileira de Ciências Criminais, RT, São Paulo, n. 6, p. 138 , abr./jun. 1994.

. Perplexidade de Jano: quando o passado é mais presente do que o futuro (nova regulamentação do interrogatório e sua aplicabilidade na fase pré-processual). In: YARSHELL, Flávio Luiz; MORAES, Maurício Zanoide (Coord.). Estudos em homenagem à Professora Ada Pellegrini Grinover. São Paulo: DPJ, 2005. p. 375.

MOURA, Humberto Fernandes. Uma condenação penal transitada em julgado, que não serve à configuração da reincidência, configura maus antecedentes perpétuos? Disponível em: <www.ibccrim.org.br>. Acesso em: 18 abr. 2005. 
MOURA, Maria Thereza Rocha de Assis. A prova por indícios no processo penal. São Paulo: Saraiva, 1994.

; MORAES, Maurício Zanoide. Direito ao silêncio no interrogatório. Revista Brasileira de Ciências Criminais, RT, São Paulo, n. 6, p. 138, abr./jun. 1994.

. Justa causa para a ação penal. São Paulo: RT, 2001.

MOYANO, Hélio A. Nogues. Um critério objetivo de antecedentes criminais. Boletim IBCCrim, São Paulo, n. 8, p. 3, set. 1993.

NOGUEIRA, Carlos Frederico Coelho. Comentários ao Código de Processo Penal. São Paulo: Edipro, 2002.

NORMAS DE SERVIÇO DA CORREGEDORIA-GERAL DA JUSTIÇA DO ESTADO DE SÃO PAULO. Publicações Eletrônicas Associação Paulista do Ministério Público. São Paulo: APMP, 2004-2006. 1 CD-ROM. Produzido por Eduardo Roberto Alcântara Del-Campo e Marinilce Araújo Soria.

NORONHA, Edgard Magalhães. Curso de direito processual penal. 18. ed. São Paulo: Saraiva, 1987.

NOTÍCIAS STF. Ministro Marco Aurélio vota contra a ação da AMB. Disponível em: $<$ http://www.stf.gov.br/portal/cms/verNoticiaDetalhe.asp?idConteudo=94226\&caixaBu...> . Acesso em: 17 set. 2008.

OLIVEIRA, Roberto. Ex-presidiário vira calouro uspiano. Disponível em: <http://www1.folha.uol.com.br/fsp/cotidiano/ff280200525.htm>. Acesso em: 12 set. 2005.

PAVAN, Laisa. Algumas considerações sobre "antecedentes" no artigo 59 do Código 
Penal. In: SANTOS, Rogério Dultra (Coord.). Introdução Crítica ao Estudo do Sistema Penal: elementos para a compreensão da atividade repressiva do Estado. Florianópolis: Diploma legal, 1999.

PEDROSA, Ronaldo Leite. Folha penal perpétua. Disponível em: $<$ http://www.nplyriana.adv.br/link_geral.php?item=artigos2_7\&titulo=Folha+Penal+Perp \%E9tua>. Acesso em 24 nov. 2004.

PEREIRA, Flávia Rahal Bresser. A publicidade no processo penal brasileiro. Confronto com o direito à intimidade. Dissertação (Mestrado em Processo Penal) - Faculdade de Direito do Largo de São Francisco, São Paulo, 2000.

PIERANGELI, José Henrique. Códigos Penais do Brasil. Evolução histórica. 2. ed. São Paulo: RT, 2004.

PITOMBO, Cleunice A. Valentim Bastos. Considerações sobre a tutela da intimidade e vida privada no processo penal. Revista Brasileira de Ciências Criminais, RT, São Paulo, n. 26, p. 63, abr./jun. 1999.

PITOMBO, Sérgio Marcos de Moraes. A identificação processual penal e a Constituição de 1988. RT, São Paulo, n. 635, p. 172, set. 1988.

POMPÉIA, Raul. O Ateneu. 16. ed. São Paulo: Ática, 1996.

PORTARIA DPF No 992, de 25 de outubro de 1995. Trata das Empresas de Segurança Privada. Publicações Eletrônicas Associação Paulista do Ministério Público. São Paulo: APMP, 2004-2006. 1 CD-ROM. Produzido por Eduardo Roberto Alcântara Del-Campo e Marinilce Araújo Soria. 
PORTUGAL. Associação Sindical dos Juízes Portugueses. Legislação. Lei 59/98, de 25 de Agosto - Código de Processo Penal. Disponível em: $<$ http://www.unifr.ch/ddp1/derechopenal/legislacion/pt/CProcPenPortugal.pdf $>$. Acesso em: 6 jan. 2008.

PORTUGAL. Código de Processo Penal Português. Disponível em: $<$ http://www.portolegal.com/CPPen.htm>. Acesso em: 13 set. 2008.

PORTUGAL. Código Penal Português. Disponível em: $<$ http://www.unifr.ch/ddp1/derechopenal/legislacion/pt/CPPortugal.pdf $>$. Acesso em: 6 jan. 2008.

PORTUGAL. Directiva 64/221/CEE do Conselho, de 25 de Fevereiro de 1964. Disponível em: $<$ http://eurlex.europa.eu/LexUriServ/LexUriServ.do?uri=CELEX:31964L0221:PT:HTML>. Acesso em: 6 jan. 2008.

PORTUGAL. Directiva do Retorno. Disponível em $<$ http://www.europarl.europa.eu/news/public/focus_page/018-32673-177-06-26-902 20080625FCS32672-25-062008-2008/defaut_pt.htm >. Acesso em: 21 out. 2008.

PORTUGAL. Decreto-Lei n. ${ }^{\circ}$ 39/83, de 25 de Janeiro, e Decreto-Lei 381/98, de 27 de Novembro. Diário da República I, 27 nov. 1998, Série-A, n. 275, p. 6576. Disponível em: $<$ http://www.dre.pt>. Acesso em: 23 jun. 2008.

PRADO, Luiz Regis; BITENCOURT, Cezar Roberto. Código Penal anotado e legislação complementar. São Paulo: RT, 1997.

PRESIDÊNCIA DA REPÚBLICA - Casa Civil - Subchefia para Assuntos Jurídicos Decreto $\mathrm{n}^{\mathrm{o}}$ 6.138, de 28 de junho de 2007. Disponível em: $<$ http://www.planalto.gov.br/ccivil_03/_Ato2007-2010/2007/Decreto/D6138.htm>. Acesso em: 14 jun. 2007. 
PROVIMENTO Nº 9, de 1992, da Corregedoria-Geral da Justiça. Publicações Eletrônicas Associação Paulista do Ministério Público. São Paulo: APMP, 2004-2006. 1 CD-ROM. Produzido por Eduardo Roberto Alcântara Del-Campo e Marinilce Araújo Soria.

PROVIMENTO No 50, de 1989. Artigo 54. Publicações Eletrônicas Associação Paulista do Ministério Público. São Paulo: APMP, 2004-2006. 1 CD-ROM. Produzido por Eduardo Roberto Alcântara Del-Campo e Marinilce Araújo Soria.

QUITO, Carina (Coord.). A esperada reforma processual penal. São Paulo, Boletim IBCCrim, n. 188, p. 1, jul. 2008.

REGISTRO.

Disponível

em:

$<$ http://michaelis.uol.com.br/moderno/portugues/index.php?lingua=portuguesportugues\&palavra=registro $>$. Acesso em: 4 nov. 2007.

RESOLUÇÃO No 33, de 10 de abril de 2007, do Conselho Nacional de Justiça. Revista A Força Policial, São Paulo: Lene Gráfica, ano 14, n. 56, p. 103-105, out./nov./dez. 2007.

ROCHA, Elaine. Certidão de antecedentes criminais expedida pelo INI é válida para comprovar reincidência. Notícia do Superior Tribunal de Justiça. Disponível em: $<$ http://www.stj.gov.br/webstj/Noticias/imprime_noticia.asp?seq_noticia+6538>. Acesso em: 13 dez 2004.

ROSA, Fábio Bittencourt da. Proporcionalidade: perigo do conceito aberto. Boletim do IBCCrim, São Paulo, n. 153, p. 5, ago. 2005.

SAAVEDRA, Miguel de Cervantes. Dom Quixote de La Mancha. Trad. Castilho e Azevedo. São Paulo: Nova Cultural, 2002. 
SABINO, Ferez. Concurso público - Certidão Negativa de Antecedentes Criminais. Exigência que contraria a Constituição. Boletim da Procuradoria Geral do Estado Centro de Estudos, São Paulo, v. 22, n. 4, p. 495-497, jul./ago. 1999.

SÃO PAULO (Estado). Aviso no 321/05-PGJ, de 14 de junho de 2005. Diário Oficial [do] Estado de São Paulo, São Paulo, SP, 17 jun. 2005. Poder Executivo, p. 33.

SÃO PAULO (Estado). Decreto n ${ }^{\circ} 11.285$, de 5 de agosto de 1940. Lex: Coletânea de legislação, São Paulo, v. 4, p. 133-134, 1940.

SARAIVA, Wellington Cabral. Antecedentes do réu e direito à suspensão condicional do processo penal. Boletim IBCCrim, São Paulo, n. 79, p. 5-6, jun. 1999.

SECRETARIA DA SEGURANÇA PÚBLICA. Disponível em: $<$ http://www2.ssp.sp.gov.br/atestado/Atestado02.cfm>. Acesso em: 28 dez. 2007.

SHIMURA, Sergio Seiji. Reabilitação - Impossibilidade da prescrição primitiva. Revista de Processo, São Paulo, n. 60, p. 178, out./dez. 1990.

SILVA, Eduardo Araújo. Crime organizado: procedimento probatório. São Paulo: Atlas, 2003.

SILVA, José Afonso. Curso de direito constitucional positivo. 9. ed. São Paulo: Malheiros, 1994.

SLAVIN, Diana de. Mercosur: la protección de los datos personales. Buenos Aires: Depalma, 1999. p. 92-93.

SOBRINHO, Mário Sérgio. A identificação criminal. São Paulo: RT, 2003. 197 p. 
SOUZA, Carlos Laet de. Da investigação policial e da instrução criminal provisória. Revista da Associação dos Delegados de Polícia do Estado, São Paulo, n. 23, p. 127-130, jun. 1997.

STOCO, Rui (Coord.); FRANCO, Alberto Silva. Código de Processo Penal e sua interpretação jurisprudencial. São Paulo: RT, 1999. v. 1.

SÚMULA No 323, de 2005, do Superior Tribunal de Justiça. Disponível em: $<$ http://busca.folha.uol.com.br/search?q=cadastro+prote $\% \mathrm{E} 7 \% \mathrm{E} 3 \mathrm{o}+\mathrm{cr} \% \mathrm{E}$ dito\&site $=$ onlin e>. Acesso em: 24 nov. 2005.

SÚMULA N $\mathrm{N}^{\mathrm{o}}$ 524, do Supremo Tribunal Federal. Disponível em: http://www.stf.jus.br/portal/cms/verTexto.asp?servico=jurisprudenciaSumula\&pagina $=$ su mula_501_600. Acesso em: 11 dez. 2008.

TELLES, Lygia Fagundes. Venha ver o pôr-do-sol \& outros contos. São Paulo: Ática, 1988.

TORNAGHI, Hélio. Comentários ao Código de Processo Penal. Rio de Janeiro: Forense, 1956. v. I., t. 1.

. Instituições de processo penal. Rio de Janeiro: Forense, 1959. v. 5.

TORON, Alberto Zacarias. A Constituição de 1988 e o conceito de bons antecedentes para apelar em liberdade. Revista Brasileira de Ciências Criminais, RT, São Paulo, n. 4, p. 71-74, out./dez. 1993.

TOURINHO FILHO, Fernando da Costa. Processo penal. 30. ed. São Paulo: Saraiva, 2008. v. 2. 
TOURINHO NETO, Fernando da Costa; FIGUEIRA JÚNIOR, Joel Dias. Juizados Especiais Estaduais Cíveis e Criminais. 4. ed. São Paulo: RT, 2005.

TUCCI, Rogério Lauria. Processo e procedimento na ação de habeas data. In: WAMBIER, Teresa Arruda Alvim (Coord.). Habeas data. São Paulo: RT, 1998. p. 335-336 e 339.

VEIGA, Catarina. Considerações sobre a relevância dos antecedentes criminais do argüido no processo penal. Coimbra: Almedina, 2000.

VIEIRA, Ana Lúcia Menezes. Processo penal e mídia. São Paulo: RT, 2003.

WANDERLICH, Alexandre. Sociedade de consumo e globalização: abordando a teoria garantista na barbárie. (Re)afirmação dos direitos humanos. In: CARVALHO, Salo de; WANDERLICH, Alexandre (Orgs.). Diálogos sobre a justiça dialogal: teses e antíteses sobre os processos de informalização e privatização da justiça penal. Rio de Janeiro: Lumem Juris, 2002.

YARSHELL, Flávio Luiz; MORAES, Maurício Zanoide (Coord.). Estudos em homenagem à Professora Ada Pellegrini Grinover. São Paulo: DPJ, 2005. 